\title{
UN NOU SIT DE TIP BASARABI. RAPORT PRELIMINAR ASUPRA CERCETĂRILOR ARHEOLOGICE PREVENTIVE LA TĂRTĂRIA-PODU TĂRTĂRIEI VEST(CAMPANIA 2012)
}

\author{
CORINA BORŞ, LUCIANA IRIMUS, VLAD RUMEGA,
} SEBASTIAN DOBROTÃ, CĀTĂLIN RIŞCUTA

\author{
A NEW SITE OF BASARABI TYPE. PRELIMINARY REPORT REGARDING THE PREVENTIVE \\ ARCHAEOLOGICAL EXCAVATIONS \\ AT TĂRTĂRIA-PODU TÄRTÄRIEI VEST (2012 CAMPAIGN)
}

\begin{abstract}
The preventive archaeological research campaign 2012 on the site Tărtăria-Podu Tărtăriei vest was occasioned by the construction of the Al motorway. The site was identified following the survey made in 2011 by an archaeological team from the National History Museum of Romania, although there were a series of earlier information concerning the archaeological potential of this area but near to DN7 route and the railway Arad-Alba Iulia. The site is located about $0.3 \mathrm{~km}$ south of DN 7/E 68 road, north to Tărtăria village, on a plateau situated on the upper left terrace of the Mures valley. The preventive archaeological investigations took place in spring and summer 2012 (March-July) and led to the discovery of very consistent archaeological vestiges. Throughout an open area archaeological excavation it was fully investigated an area of about 2 ha, where 269 archaeological complexes (mostly from the middle Hallstatt period - the Basarabi ceramic style) were investigated. There have been excavated a variety of archaeological remains, e.g. (possible) semi-sunken dwellings, offering pits (with pottery broken in situ), refuse and extraction pits, but also certain particular vestiges - two ditches marking the southern and easten limits of the site, two bronze hoards (comprising 400 bronze and iron objects, dated to the $\mathrm{Ha} \mathrm{C}_{1}$ period - the Bâlvăneşti-Vinţ series, $8^{\text {th }} \mathrm{c}$. BC) and a collective grave. Also, there was uncovered a large quantity of pottery of Basarabi type, as well as a great number of metal objects (weapons, tools and adomments of bronze and iron). Considering all the data recorded and the preliminary analysis of the very rich archaeological finds from Tărtăria-Podu Tărtăriei vest, this is a very important site from the middle Hallstatt period.
\end{abstract}

KEYWORDS: middle Hallstatt period, bronze hoards, collective grave, Basarabi type pottery CUVINTE CHEIE: perioada Hallstatt-ului mijlociu, depozite de bronzuri, mormânt colectiv, stil ceramic Basarabi

\section{INTRODUCERE}

Situl hallstattian (de tip Basarabi) Tărtăria-Podu Tărtăriei vest a fost descoperit cu ocazia lucrărilor de diagnostic arheologic și cercetare preventivă întreprinse, de către o echipă de arheologi de la Muzeul Național de Istorie a României (MNIR), în perioada 2011-2012 (PI. VIII). Aceste investigații arheologice s-au desfasşurat în cadrul Programului Național de Cercetare „Autostrada”, coordonat de MNIR, prin dr. Paul Damian'.

Situl este localizat în jud. Alba, com. Săliștea ${ }^{2}$, satul Tărtăria. Ținând cont de toponimele locale, situl a fost denumit Tărtăria-Podu Tărtăriei vest, pentru a face distincția clară de binecunoscutul sit neolitic (anume Tărtăria-Gura Luncii). Situl hallstattian este situat în punctul Podu

\footnotetext{
${ }^{1}$ Dorim să mulțumim și pe aceastà cale, dr. Paul Damian pentru oportunitatea de a efectua cercetări în cadrul acestui sit.

${ }^{2}$ Actuala denumire Sălişte este una de dată recentă (1964-1965). Anterior, vreme de peste cinci secole, această localitate a fost cunoscută sub numele de Cioara (în maghiară: Alsócsóra, în germană: KrähendorffTschora), prima sa atestare documentară datând din 1458. De asemenea, este de menţionat şi existenţa hidronimului Cioara (în maghiară: Csórapatak), pârâu afluent stâng al Mureşului, situat la vest de comuna Săliște şi satul actual Tãrtăria.
} 
Tărtăriei vest, pe a doua terasă a Mureşului, pe malul stâng, la S de DN7 şi la V de DC705E (PI. II). Zona acestuia, denumită provizoriu - cu ocazia lucrărilor de diagnostic din toamna anului 2011 Tărtăria 1, a fost delimitată preliminar între $\mathrm{km} \mathrm{14+100} \mathrm{şi} \mathrm{km} 14+5100$ pe traseul autostrăzii Al tronson 1, existenţa potenţialului arheologic fiind ulterior confirmată - prin cercetare de tip ,open area excavation" - între km 14+240/250 şi km 14+540. (PI. IX)

Suprafaţa reperată a sitului ${ }^{3}$ este de peste 150.000 m.p. (peste $15 \mathrm{ha}$ ). În contextul cercetărilor arheologice preventive ocazionate de lucrările de construire a autostrăzii Al, tronson Orăștie - Sebeș, a fost investigată din punct de vedere arheologic o suprafaţă din porţiunea delimitată a sitului însumând 50.546 m.p. $(5,05$ ha), respectiv a fost cercetată exhaustiv prin săpătură arheologică preventivă de tip ,open area excavation', o zonă totalizând 18.374 m.p. (1,83 ha).

Descoperiri arheologice (din perioada Hallstatt-ului mijlociu) ce pot fi puse în legătură cu situl Tărtăria-Podu Tărtăriei vest - imediat spre nord şi est de acesta - sunt cunoscute de la jumătatea secolului $\mathrm{XX}^{5}$, acestea fiind prilejuite de lucrările la şoseaua naţională Alba Iulia/Sebeş - Deva (PI. III). Trebuie menţionat însă că este vorba de descoperiri întâmplătoare şi cercetări de teren de mică amploare, toate acestea fiind fácute în afara ariei sitului delimitat în toamna anului 2011 şi primăvara anului 2012, respectiv cercetat în campania 2012 de echipa de arheologi din cadrul MNIR. Mai mult decât atât, localizarea şi reperele geografice/topografice referitoare la cercetările de teren şi descoperirile mai vechi sunt de cele mai multe ori destul de relative, existând astfel unele confuzii inerente ${ }^{6}$.

În urma solicitării firmei STRABAG S.R.L. adresate MNIR, în prima parte a trimestrului I al anului 2012, între cele două părţi s-a încheiat un contract de prestări servicii în vederea efectuării lucrărilor de cercetare arheologică preventivă pe traseul viitoarei autostrăzi A 1 Orăştie-Sibiu, Lot 1

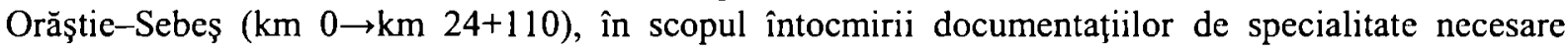
derulării procedurii de descărcare de sarcină arheologică, în conformitate cu prevederile legale.

Evaluarea arheologică (teoretică şi de teren) desfăşurată în perioada octombrie-decembrie 2011 , cât şi cercetarea arheologică preventivă efectuată în perioada lunilor martie-iulie 2012 au fost realizate în conformitate cu legislaţia în vigoare privind protejarea patrimoniului arheologic (OG nr. 43/2000 cu modificările ulterioare, OMCC nr. 2392/2004 și OMCPN nr. 2613/2011), în baza autorizațiilor emise de către Ministerul Culturii şi Patrimoniului Naţional - Direcţia Patrimoniu Cultural. Echipa de cercetare în teren a fost coordonată de dr. Corina Borş (responsabil ştiinţific, arheolog specialist), fiind alcătuită din 4 arheologi, angajał̧i permanenţi sau contractuali în cadrul Muzeului Național de Istorie a României, respectiv un arheolog din cadrul Muzeul Civilizației Dacice şi Romane (Deva), în baza unui contract instituțional de subcontractare.

\footnotetext{
${ }^{3}$ Suprafaţa sitului denumit convenţional Tărtăria-Podu Tărtăriei vest este cu mult mai mare decât zona afectatã de lucrările de construire a autostrăzii Al Orăştie-Sibiu (Pl. III, VII), după cum vom arăta în cele ce urmează. Astfell, coroborarea informaţiilor bibliografice (RepAB 1995, 186; Ciugudean 1997, 148; Ursuţiu 2002, 98 care preiau o serie de referinţe mai vechi) cu observaţiile directe efectuate în cursul săpăturilor arheologice preventive şi materialele arheologice descoperite în perieghezele efectuate în perioada martie-august 2012 indică existenţa unei stał̧iuni preistorice de mari dimensiuni (de peste 10 ha) situată în partea nordică a zonei denumită Podu Tărtăriei, situat la S de DN 7, pe malul stâng al Mureşului, în raza administrativă a satului Tărtăria, între Valea Ciorii la vest şi Valea Rea la est. Foarte probabil aceastã aşezare preistorică a fost afestată succesiv, în părţile de nord şi nord-est, în cursul secolului al XIX-lea de construirea căii ferate Arad-Alba Iulia (1867-1868), iar în cel următor de construcţia DN7 şi DC705E.

${ }^{4}$ Pentru detalii privind notiunea de „open area excavation” vezi infra nota 12.

${ }^{5}$ Horedt 1947-1949, 44-49; RepAB 1995, 186-187

${ }^{6}$ Ursuţiu 2002, 98-99. În sinteza sa privind etapa mijlocie a primei epoci a fierului în Transilvania, A. Ursuţiu presupune în mod eronat, căci datele primare nu sunt incerte - că informaţiile din Repertoriul Arheologic al judeţului Alba şi cele publicate de Ciugudean 1997 ar fi incorecte şi de fapt cele două puncte cu descoperiri de tip Basarabi - situate de o parte şi de alta a DN7 - ar constitui vestigiile unei singure aşezări. Î́n opinia noastră există trei posibilităţi în ceea ce priveşte materialele de tip Basarabi indicate în literatura de specialitate ca provenind din aceastā zonā: ori descoperirile fácute la $N$ de DN7 şi calea feratã Arad-Alba Iulia, pe prima terasă a Mureşului, în punctul Tărtăria-Gura Luncii, reprezintă material în poziţie secundară (fiind recoltate din arătură) provenit din aşezarea cercetată de noi în anul 2012, caz în care suprafaţa sitului este foarte mare, zona ocupată de acesta având o deschidere pe direçia S-N de peste $600 \mathrm{~m}$, sau este vorba de douã zone de locuire distincte (una situată pe prima terasă a Mureşului, iar cealaltă pe a doua), ori ambele puncte semnalate pe terasa inferioară reprezintă numai locuri de unde a fost recuperat material în poziţie secundară (,scurs”) din situl aflat pe terasa a II-a (superioară). În sprijinul acestei ultime ipoteze credem că pledează şi o descoperire mai recentă (2000) din punctul Tărtăria-Pietroșita (Ghenescu, Sana, Ştefu 2000, 82-83), situat pe prima terasă a Mureşului, la circa $1 \mathrm{~km}$ NE de situl Tărtāria-Podu Tărtăriei vest.
} 
Având în vedere că între cele mai apropiate semnalări (referitoare la materiale din perioada așa-numitei culturi Basarabi) şi zona propriu-zis investigată în campania 2012 este o distanţă de circa $400 \mathrm{~m}$, se poate afirma că existenţa certă a sitului Tărtăria-Podu Tărtăriei vest a fost stabilită cu ocazia lucrărilor de diagnostic arheologic efectuate de o echipă de arheologi din cadrul MNIR în toamna anului $2011^{7}$. Cu acel prilej, dar și în cursul campaniei arheologice 2012 au fost efectuate o serie de recunoaşteri de teren, precum şi o documentare istorico-arheologică generală (PI. I, II). De asemenea, având în vedere definitivarea traseului viitoarei autostrăzi A1 - tronson 1 , arheologi din cadrul MNIR au efectuat mai multe sondaje care să permită o delimitare mai exactă a zonelor cu potenţial arheologic pe traseul viitoarei căi rutiere între Orăştie şi Sebeş, implicit şi în zona Tărtăria (PI. VIII). Este de amintit faptul că la finalul deceniului trecut, o echipă de arheologi de la Muzeul Naţional al Unirii Alba Iulia au efectuat lucrări preliminare de diagnostic arheologic în legătură cu construirea viitoarei autostrăzi $\mathrm{Al}$, însă la vremea respectivă proiectul acesteia nu era pe deplin stabilit.

Trebuie menţionat că în ultimele decenii, zona sitului a fost putemic afectată de lucrări agricole, fapt observabil atât pe imagini aeriene și hărți de arhivă, cât şi direct, cu prilejul cercetărilor din anii $2011-2012^{8}$. (PI. II, V, VII)

Cercetările arheologice cu caracter preventiv, efectuate în primăvara și vara anului 2012, de-a lungul a circa 16 săptămâni (de lucru efectiv în teren), în perioada 17 martie - 25 iulie 2012 (program de lucru 10 ore zilnic, 6 zile pe săptămână cu excepţia zilelor cu intemperii ${ }^{9}$ ), au confirmat - pe de-o parte - prezenţa substanţială a potenţialului arheologic semnalat anterior, cu mențiunea că s-a dovedit a fi vorba de descoperiri încadrabile în perioada Hallstatt-ului mijlociu (perioada culturii Basarabi/Ha $\mathrm{B}_{3}-\mathrm{C}$, secolele IX-VIII a. Chr.) și nu - cum s-a crezut inițial - aparținând epocii bronzului ${ }^{10}$, iar pe de altă parte au condus la descoperirea unei fortificaţii (val cu palisadă), databilă preliminar în perioada Evului Mediu timpuriu (secolele X-XII ?), vestigiu arheologic necunoscut anterior ${ }^{11}$ (PI. XI, XIII, XIV, XXI-XXIII). Astfel, au fost identificate şi investigate exhaustiv 269 de complexe şi contexte arheologice distribuite pe o suprafaţă de circa 2 ha, între km 14+240/250 şi km 14+540 ai traseului

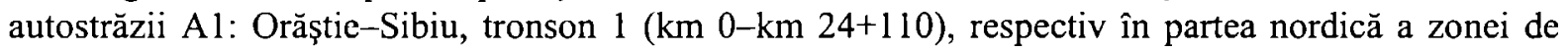
relocare a DC705E (PI. IX, XI-XIV).

În acest context a fost investigată exhaustiv, prin săpătură arheologică de tip ,open area excavation" "12, o suprafaţă de aproximativ 20.000 m.p. (2 ha), situată între km 14+100 şi km 14+540 ai autostrăzii Al, anume în ampriza acesteia cu o deschidere de circa $90-100^{13} \mathrm{~m}$ şi în partea nordică a zonei de relocare a DC705E (o suprafaţă adiţională de cercetare cu dimensiuni de circa $120 \mathrm{~m}$ lungime şi 35-40 m lăţime, afectată în extremitatea sa nordică de existenţa unor magistrale de gaze).

Cercetare arheologică preventivă, efectuată în campania 2012, a urmărit să determine, pe cât mai mult posibil, caracteristicile şi poziţionarea spaţială a eventualelor vestigii arheologice în

\footnotetext{
${ }^{7}$ De remarcat faptul că toate semnalările din bibliografia de referinţă sunt localizate exclusiv în zona primei terase a Mureşului (de fapt a doua terasă din punct de vedere geologic, n.n.), principalele repere indicate fiind traseul DN7, calea ferată Arad-Alba Iulia şi cantonul Haltei C.F.R. Tărtāria.

8 De asemenea, folosinţa terenurilor pentru lucrări agricole şi efectuarea ritmică a unor arături adânci a fost confirmatã de diverși localnici, fie angajał̧i temporar ca muncitori necalificaţi pentru lucrări arheologice în primăvara - vara 2012, fie de diverşi localnici care au vizitat săpăturile şi cu care am discutat direct. Între aceştia îi amintim pe preotul Gheorghe Marin şi doamna Viorica Neghină, din satul Tărtăria, cărora le mulł̧umim şi cu această ocazie pentru informaţiile utile oferite.

9 Perioadă foarte ploioasă în special în lunile aprilie-mai, astfel că in total pentru perioada 17 martie-25 iulie $2012, \mathrm{~s}-a u$ înregistrat peste 3 săptămâni cumulate de zile de ploaie. De asemenea în acelaşi interval a existat o săptămână de pauză de lucru în teren, datoritã vacanţei de Paşte (12-18 aprilie 2012).

10 Damian et alii 2012, 280, nr. 156

$11 \mathrm{Cu}$ prilejul lucrărilor de diagnostic arheologic în toamna anului 2011, limita esticã a sitului Tărtăria 1 (denumire convențională) a fost stabilită la km 14+500. În primăvara anului următor, în luna mai 2012, Beneficiarul ne-a comunicat modificarea proiectului initial de construire, prin includerea unei zone suplimentare necesară pentru relocarea DC705E. În acest context, cercetarea a fost extinsă spre $E$, prilej cu care au fost identificate urmele unei fortificaţii în porţiunea dintre km 14+500 şi km 14+540. Vezi infra, secțiunea Scurtă prezentare a strategiei de săpătură.

12 Principiul pe care se bazeazã săpătura de tip „open area excavation” (n.n. săpătură în suprafaţă deschisă), este acela că astfel — în chip ideal - este investigat întregul sit, prin expunerea, înregistrarea și îndepărtarea fiecărui ,depozit” arheologic, în mare măsură în ordinea inversă a fonnării respectivelor depuneri. De exemplu, vezi Drewett 2011, 92-93.

13 În prima lună de cercetare limitele de expropriere necesare pentru construirea viitoarei autostrăzi nu au fost marcate în teren de Beneficiar, iar ulterior au survenit o serie de modificări subsecvente ale proiectului în sensul extinderii considerabile a ariei de cercetare arheologică preventivă.
} 
cuprinsul zonei direct afectate de viitoarele lucrări de construire a autostrăzii amintite. Astfel, au fost utilizate diverse metode, tehnici şi bune practici uzuale în domeniul arheologiei preventive şi al cercetării de teren vizând salvgardarea prin înregistrare (preservation by record ${ }^{14}$ ) a contextelor şi vestigiilor arheologice.

\section{DATE FIZICO-GEOGRAFICE PRIVIND SITUL ${ }^{15}$}

Situl arheologic Tărtăria-Podu Tărtăriei vest este situat la circa $0,3 \mathrm{~km}$ sud de traseul DN 7/E 68, în raza administrativă a satului Tărtăria, com. Săliştea (fostă Cioara), jud. Alba, respectiv în partea dreaptă a DC705E, care asigură accesul din drumul naţional către localitatea amintită (coordonate: latitudine $-45^{\circ} 56^{\prime} 36,82^{\prime \prime} \mathrm{N} /$ longitudine $-23^{\circ} 24^{\prime} 28,69^{\prime \prime} \mathrm{E}$, altitudine $231 \mathrm{~m}$ ). Situl se află pe malul stâng al Mureşului, pe a doua terasă a râului, în extremitatea nordică a acestcia, fiind mărginit la E de pârâul Valea Rea, iar la V de pârâul Cioara. (PI. I, II)

Teritoriul comunei Săliştea are formă relativ liniară, orientată pe direcţia NE-SV, cu două ramificaţii spre sud. Comuna este situată în partea sudică a judeţului Alba, ocupând un areal care suprapune în bună parte bazinul hidrografic al văii Cioara. Comuna Săliştea se află la o distanţă de 27 $\mathrm{km}$ de municipiul Alba Iulia, la $25 \mathrm{~km}$ de oraşul Cugir şi la $21 \mathrm{~km}$ de Sebeş. Comuna se învecinează cu următoarele localităţi: spre $\mathrm{N}$ cu comuna Blandiana, către NE cu comuna Vinţu de Jos, spre E cu comuna Pianu, către V cu oraşul Cugir şi spre NV cu comuna Şibot.

Din punct de vedere geografic situl se află în Depresiunea Transilvaniei, aceasta formându-se ca urmare a unor procese tectonice succesive ce au determinat apariția lanf̧ului muntos carpatin. Depresiunea Transilvaniei este situată în interiorul arcului carpatic, având o altitudine medie de 400$600 \mathrm{~m}$. Din punct de vedere hidrografic zona aparține bazinului râului Mureș. Valea Mureșului formează limita dintre Câmpia deluroasă a Transilvaniei, în centru și Dealurile Târnavelor, în sud, cu un relief mai proeminent. Culoarul Mureşului este una din subdiviziunile Podişului intracarpatic; acesta se întinde pe o lungime de circa $70 \mathrm{~km}$ între localitățile Vinţu de Jos şi Turda ${ }^{16}$. Întrucâtva artificial, la vest de Vinț și până la Orăștie, valea Mureșului este cunoscută și sub denumirea de Culoarul Orăştiei. Zona depresionară a Culoarului Orăştie este de origine post-tectonică, fiind caracterizată prin înălţimi relativ mici (200-300 m) şi pante de scurgere reduse, în care întâlnim şapte terase, de origine cuaternarăă ${ }^{17}$.

Valea Mureşului mijlociu constituie o micro-zonă geografică deosebit de propice locuirii, atât prin caracteristicile sale morfologice (zone de luncă cu terase având altitudini relative joase şi medii altemând cu terase mai înalte, mai largi, etajate pe două sau chiar trei niveluri ${ }^{18}$ ), cât şi prin cele climatice (un climat blând, mediu temperat favorizat de existenţa fenomenului particular al acţiunii föhn-ului dinspre pantele Munţilor Apuseni şi intruziuni de aer cald dinspre zona Banatului, vânturile dominante fiind pe direcţia sud-vest ${ }^{19}$ ).

\footnotetext{
${ }^{14}$ Prin acest termen se înțelege - în general - identificarea şi cercetarea exhaustivă a unor situri (vestigii) arheologice, efectuate în contextul ameninţării integrităţii acestora de către viitoare activităţi de construire sau în cel al realizării unui studiu de impact asupra mediului (situaţie prevăzută în Convenţia Valletta și legiferată în legislaţia românească referitoare la protejarea patrimoniului arheologic). O asemenea abordare este complementară - după caz, în funcţie de semnificaţia și importanţa descoperirilor - demersului de conservare in situ a unora dintre vestigii, precum şi cu o serie de măsuri preventive ce pot fi întreprinse pentru a salvgarda un sit identificat, dar neexcavat. Conceptul de „prezervare prin înregistrare"/,salvagardare prin studiu" este relativ nou şi relativ neclar explicitat - pentru moment - în cadrul politicilor de protejare a patrimoniului arheologic prevăzute de legislaţia românească de specialitate, dar este aplicat - pe scară largă - în numeroase ţări europene şi în SUA. Pentru mai buna înţelegere a acestui concept în practica arheologică internaţională vezi: preservation by record - Roskams 2001, 35-36; Grant et alii 2005, 27-28, 128-129; PPGl 6, secţiunea 25; mitigation through data recovery - Neumann, Sanford 2001, 201-242; Green 2002, 104-105; Grant et alii 2005, 129; sauvegarder par l'étude - în sensul dat în Franţa de legea arheologiei preventive, respectiv Legea nr. 2001-44/2001.

${ }^{15}$ La redactarea acestui subcapitol au fost utilizate o serie de informaţii disponibile pe site-ul oficial al Primãriei com. Săliştea, la adresa http://www.comuna-salistea.ro/ro/index.php [accesat în data de17.01.2013].

${ }^{16}$ Tufescu 1966, 198

${ }^{17}$ Popa 2011, 20

${ }^{18}$ Tufescu 1966, 203

${ }^{19}$ Geografia, I, 248
} 
Din punct de vedere geologic, pe teritoriul judeţului Alba sunt întâlnite două mari unităţi tectonice structurale: autohtonul danubian şi pânza getică ${ }^{20}$. Astfel, Carpaţii Meridionali aparţin zonei cristalino-mezozoice, iar cea a Carpaţilor Apuseni de sud zonei sedimentar vulcanice. Situat pe cursul mijlociu al Mureşului, Culoarul Orăştiei aparţine unei depresiuni intramontane încadrată la $\mathrm{N}$ de munţii Trascăului, la S de Munţii Şureanu, la E de Depresiunea Transilvaniei şi la V de Munţii Poiana Ruscă. Per ansamblu, Culoarul Orăştiei are un caracter deluros în partea sa sudică, în vreme ce partea nordică este alcătuită din terase şi lunci ${ }^{21}$. Caracterizarea Culoarului Orăştiei ca depresiune deluroasă nu reflectă cu exactitate trăsăturile orografice, pentru că de fapt numai aproximativ o treime din suprafaţa sa are o fragmentare deluroasă. Cealaltă parte - mult mai întinsă - este o asociere de câmpuri şi şesuri aluviale dispuse în trepte cu aspectul unei adevărate câmpii de terase, construite de-a lungul cursului Mureşului. Aspectul zonei este modelat de contribuţia substanţială a cursurilor de apă venite dinspre Munţii Şureanu, ceea ce a determinat o asimetrie pronunţată a întregului culoar. Râul Mureşul, situat spre nordul acestei unităţi geografice, şi-a format o luncă destul de largă $(2-5 \mathrm{~km})$, lipită de poalele Munţilor Metaliferi. Terasele de pe stânga văii Mureşului sunt dispuse pe 6-7 nivele, iar cea mai veche ajunge la 140-150 m înălţime relativă. Pe alocuri, terasele inferioare au o întindere mai amplă, de câţiva kilometri şi sunt numite de localnici „câmpuri” (de exemplu, Câmpul de Sus, Câmpul de Mijloc, Câmpul de Jos, Câmpul Pâinii). Toate nivelurile sunt îndreptate către lunca Mureşului, iar pe alocuri par că se desprind unele din altele, ceea ce le conferă un aspect piemontan. Relieful mai înalt se desfăşoară lângă abruptul munţilor, ca o prispă deluroasă, formată dintr-un ansamblu de culmi aproape paralele, dar şi cu ramificaţii secundare, ici şi colo conturându-se mici noduri orografice, care însă nu ating în nici un punct altitudinea de $600 \mathrm{~m}$. Toate aceste culmi, la altitudinea de $400-450 \mathrm{~m}$, cu tendinţă de înălţare spre marginea muntelui până la $500 \mathrm{~m}$, se asociază într-o singură treaptă piemontană.

Din punct de vedere geografic, teritoriul comunei Săliştea cuprinde două forme de relief: zona de luncă şi terase joase ale râului Mureş şi afluenţilor acestuia, respectiv zona de terase înalte şi podiş, foarte propice practicării agriculturii, iar în partea de sud zona de dealuri, un relief fragmentat de afluenţi şi pâraie de munte mai puţin favorabile dezvoltării agriculturii. Pe partea însorită se cultivă viţă de vie şi pomi fructiferi. De asemenea, în cuprinsul comunei (în partea sa sudică) există păşuni şi fânețe naturale destul de întinse.

În ceea ce priveşte reperele hidrografice, zona sitului în discuţie este mărginită la $\mathrm{N}$ de valea mijlocie a Mureşului, la E de Valea Tărtăriei (Valea Rea) şi la V de pârâul (valea) Ciorii. Este de remarcat faptul că râul Mureş produce inunda̧̧ii dese, catastrofale uneori pentru producţia agricolă; ultimele inundaţii majore cauzate de Mureş în zona com. Săliştea au fost cele din anul 1995 care au durat cca 7 zile. Teritoriul comunei este străbătut, pe direcţia N-S, de cursul văilor Cioara, Tărtăria şi Pietroasa, care de asemenea, în ultimii ani produc inundaţii locale.

Dealurilor înalte le corespund solurile brune şi brune-roşcate de pădure, slab sau puternic podzolite sau podzolite secundar, în vreme ce pe terasele şi dealurile piemontane din depresiuni sunt frecvente asocierile de cemoziomuri, soluri brune de terasă, solurile brune şi cele brun roșcate de pădure ${ }^{22}$. De-a lungul văii Mureşului, râu cu luncă extinsă, există soluri aluviale, gleice şi cernoziomuri levigate. Predominarea suprafețelor orizontale şi slab înclinate a favorizat păstrarea unor soluri evoluate, în egală măsură pe culmile piemontane împădurite, pe terase, în luncile Mureşului şi afluenţilor lui, precum și pe versanţii slab înclinaţi, acoperiţi cu deluvii stabile. Aceasta nu înseamnă că pe versanţii moderat şi puternic înclinaţi din dealurile văilor mai importante şi din vecinătatea munţilor, sau pe frunţile (boturile) teraselor nu apar soluri erodate, rogosoluri şi chiar rocă la zi, cu precădere sub influenţa activităţilor antropice de dată recentă.

Pentru micro-zona geografică unde este situat situl sunt întrunite caracteristicile unui climat continental moderat de deal. Punctual, arealul com. Săliştea este situat într-o zonă destul de ocrotită, cu temperaturi medii anuale între 5-9 grade şi o cantitate medie anuală de precipitał̧ii de peste $600 \mathrm{ml}$. Vânturile cele mai frecvente bat dinspre vest, concentrându-se de-a lungul văilor mai mari. Mici diferenţe de climă se înregistrează pe versanţii sudici care sunt favorabili viticulturii și pomiculturii.

\footnotetext{
$20 * * * 1982,513$

$21 * * * 1982,514$

$22 * * * 1982,33$
} 
Ca fenomene meteo negative pentru zona în discuţie sunt de notat înghef̧urile târzii şi brumele timpurii, dar şi ceţuri frecvente în dimineţile şi serile de primăvară şi toamnă.

Documentele cartografice din a doua jumătate a secolului al XVIII-lea ${ }^{23} \mathrm{nu}$ conţin foarte multe detalii, dar este clar observabil că zona sitului cercetat, aflat în vecinătatea satului Tărtăria, nu era împădurită, fiind de presupus practicarea agriculturii (PI. I). Pentru zona sitului în discuţie sunt de remarcat însă două detalii conţinute de harta ridicării topografice iosefine şi anume: 1 . existenţa pe latura estică a sitului, paralel cu actualul traseu al DC705E (dar nu în Valea Tărtăriei ci pe versantul vestic al acestuia) al drumului denumit „Drum Trajan” (fără însă alte precizări legate de existenţa unor vestigii antice, aşa cum este cazul pentru alte localităţi învecinate ca de ex. Şibot); 2. existenţa în partea nordică a terasei pe care se află situl a vechiului drum Orăștie-Sebeşşi a unui han (birt) (marcat clar cu denumirea Wirthshaus) chiar în capătul nordic al vãii Tărtăria (identificată cu toponimul „Valje din Scholz”). Din păcate, următoarele două cartări habsburgice realizate în secolul al XIX-lea nu conţin date suplimentare. Practicarea intensivă a agriculturii, începând cu a doua jumătate a secolului XX, în zona sitului este un fapt cert - stabilit pe baza mărturiilor localnicilor şi a observaţiilor stratigrafice directe - şi a reprezentat un factor determinant de perturbare a depunerilor arheologice.

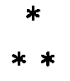

Prima atestare documentară a actualei comune Săliştea (şi implicit a localităţii Tărtăria), ca vatră de sat, este reprezentată de un document din 4 noiembrie 1310, care menţionează faptul că regele Carol Robert a dăruit comitelui Reneriu din Vinţu de Jos, satul Archişul Românesc (,pământ aflător între pământurile Vinerea, Archişul Săsesc şi Pian”). Alături de această aşezare medievală apare amintit şi satul Drejman (atestat încă din iunie 1375, conform unui document emis la Sibiu). Cele două vetre de sat au fost - cel mai probabil - numite după văile Archiş şi Drejman. Există mărturii documentare ulterioare potrivit cărora satul Cioara - atestat la 23 mai 1458 - s-a format prin unirea celor două vetre Archiş şi Drejman, în jurul curţii familiei nobiliare Barcsay, care prin cei doi fii Ioan şi Ladislau ai Elisabetei, apar ca moştenitori ai domeniului Archişul Român într-un document datat 3 martie 1340. Într-un act emis la Turda, în 14 aprilie 1508, familia Barcsay, pe lângã proprietăţile din comitatul Hunedoara şi comitatul Alba, deţineau de asemenea Cioara, Archiş şi

\footnotetext{
${ }^{23}$ Ridicarea topografică iozefină (în germană Josephinische Landesaufnahme), denumită şi Prima ridicare topografică, este cel dintâi proiect unitar de ridicare topografică la nivelul Imperiului Habsburgic. Cele 3589 planşe iniţiale, desenate şi colorate de mână, au fost apoi completate până la 4096 de secţiuni. Această lucrare a fost denumitã după împăratul Iosif al II-lea. În prezent aceste documente istorice sunt păstrate în Arhiva de război (Kriegsarchiv) a Arhivelor de Stat ale Austriei. Realizarea hărților Imperiului Austriac din a doua jumătate a secolului al XVIII-lea a avut o motivaţie militară: în timpul Războiului de Şapte Ani (1756-1763), trupele austriece au simţit acut lipsa unor hărți precise. Ca urmare, în 1764, feldmareşalul Leopold Josef von Daun i-a propus împărătesei Maria Tereza să ordone ofiţerilor din Statul Major General să cartografieze unitar toate ţările componente ale Imperiului. Până la această dată, realizarca hărţilor era în atribuţia proprietarilor funciari, care comandau hărţi ale proprietăţilor lor. În data de 13 mai 1764, după ce a primit încuviinţarea suveranei, Consiliul de Război (Hofkriegsrat) a dat ordinele de începcre a primei ridicări topografice generale la nivelul Imperiului Austriac. Ridicarea topografică începută sub domnia Mariei Tereza a fost terminată sub cea a lui Iosif al II-lea. Hățile erau realizate la scara de 1 fol vienez $=400$ klafteri vienezi (ceea ce corespunde aproximativ cu scara de $1: 28.800$ ). Variaţiile de altitudine erau redate prin haşuri și nu prin curbe de nivel. Având la bază aceste ridicări topografice, s-au confecţionat hărţi la scara de aproximativ 1:115.200. Si acest set este considerat ca fiind partc din Josephinische Landesaufnahme. Cea de a doua ridicare topografică Zweite oder Franziszeische Landesaufnahme (cea de-a doua sau ridicarea franciscană) este o realizare de seamă a ridicărilor topografice care au avut loc în Imperiul Austro-Ungar. Realizarea ei a fost iniţiată în timpul domniei lui Francisc I (1804-1835), primul împărat al Imperiului Austriac şi ultimul împărat al Sfântului Imperiu Romano de naţiune germană. Conţinutul, desenul şi estetica sunt remarcabile. Deși datorită duratei mari a ridicării (1806-1869) nici din punctul de vedere al conţinutului şi nici ca realizare tehnică nu poate fi considerată unitară, experienţa ultimilor ani ne demonstrează că planurile respective pot fi utilizate şi la ora actuală. Cea dea treia ridicare topograficā, Franzisco-Josephinische Landesaufnahme sau Dritte Landesaufnahme, și-a primit numele după cel al împăratului Franz Joseph I. Aceasta a fost realizată între 1869 şi 1887 . Planşele de bază, aşa numitele Aufnahmeblätter, au fost ridicate la scara 1:25000 sau 1:12500, iar aşa-numitele hărți speciale au fost ridicate la scara 1:75000. Resursă cartografică este disponibilă on-line la adresa http://earth.unibuc.ro/download/harile-austriece-1910reproiectate-in-stereo70 (accesată la 05.06.2013).
} 
Drejman. În ceea ce priveşte toponimul Tărtăria acesta apare clar atestat odată cu secolul al XVIII-lea, fiind menţionat pe hărţile iosefine, deşi există unele indicii privind utilizarea sa anterioară, posibil încă din secolul al XIII-lea, cel mai probabil în legătură cu invaziile tătare în zona Transilvaniei.

\section{SCURT ISTORIC AL DESCOPERIRILOR ARHEOLOGICE ÎN ZONA LOCALITĂTII TĂRTĂRIA}

Semnalările unor descoperiri arheologice fortuite în zona com. Săliştea (fostă Cioara) datează de la începutul secolului al XIX-lea, anume în 1821 fiind descoperit la est de sat, către Pianu de Sus, un tezaur de obiecte de podoabă dacice databil în secolul I a. $\mathrm{Chr}^{24}$. La jumătatea secolului al XIX-lea, M. Ackner, notează existenţa unor urme de cetate veche pe coasta de sud-vest a dealului de lângă sat, fără alte precizări; informaţia însă nu se regăseşte în repertoriul arheologic al lui I. Marţian (1920). Un secol şi ceva mai târziu, în 1944, D. şi I. Berciu efectuează săpături de mică amploare la S de sat, în punctul numit „Sálişte", la confluenţa pâraielor Archiş şi Pietroasa, într-o aşezare preistorică cu niveluri de locuire ce au fost atribuite (pe baza materialului ceramic) culturilor Coţofeni şi Wietenberg $^{25}$. Dintr-o serie de alte puncte neprecizate din jurul localităţii provin o serie de obiecte arheologice databile în epoca bronzului (topor de granit, „secure" de bronz, brăţară de bronz, ceramică), perioada dacică (monedă dacică de argint de tip Filip al II-lea), epoca romană (denar republican, denar imperial din perioada lui Vespasian, obiecte mărunte din bronz, o lespede funerară, trei monede din secolul al III-lea p. Chr. şi una din timpul lui Constantius). Analizând aceste informaţii sumare este de presupus că acestea se referă la descoperiri făcută în zona sudică a actualei comune, la peste $1 \mathrm{~km}$ distanţă de situl Tărtăria-Podu Tărtăriei vest.

În ceea ce priveşte menţiunile despre descoperirile arheologice asociate propriu-zis satului Tărtăria, cele dintâi dintre acestea datează din prima jumătate a secolului XX, concentrându-se în zona traseului DN7 şi a căii ferate Alba Iulia-Arad. Unul dintre punctele de interes este cel de lângă halta C.F.R. Tărtăria, identificat prin toponimul „Gura Luncii”, pe prima terasă (în fapt a doua din punct de vedere geologic n.n.) unde se află binecunoscuta aşezare neolitică. Din acest punct, provin o serie de fragmente ceramice caracteristice stilului ceramic Basarabi ${ }^{26}$ (faza timpurie cf. încadrării lui H. Ciugudean ${ }^{27}$ ), însă acestea provin din periegheză, fiind recoltate din arătură. Din punctul numit „Valea Rea”, deasupra cantonului C.F.R. amintit, dintr-o zonă situată în partea dreaptă față de traseul DN7 (direcţia Orăştie-Sebeş) provin o serie de fragmente ceramice aparţinând culturii Coţofeni ${ }^{28}$. La V de aceeaşi haltă C.F.R., în imediata vecinătate a traseului DN7 sunt semnalate alte descoperiri de materiale ceramice atribuite culturii Basarabi ${ }^{29}$. Pe o terasă învecinată punctului „Gura Luncii”, în partea dreaptă a căii ferate a fost descoperită accidental în 1983 o imitaţie din argint a unei monede republicane $^{30}$. Cele mai recente informaţii despre descoperirile de tip Basarabi din zona Tărtăria sunt cele incluse în volumul monografic privind etapa mijlocie a primei epoci a fierului în Transilvania datorat lui A. Ursuţiu, însă acestea sunt exclusiv preluări ale datelor mai vechi din bibliografia de referință, fără nici o altă completare ${ }^{31}$.

Așa cum menționam anterior, există însă și o serie de descoperiri arheologice (datând din perioada Hallstatt-ului mijlociu) ce pot fi puse în legătură directă cu situl Tărtăria-Podu Tărtăriei vest. Este vorba de săpăturile efectuate de către $\mathrm{K}$. Horedt ${ }^{32}$, în anii '30 ai secolului trecut, imediat spre nord şi est de situl cercetat de noi în anul 2012. (PI. III)

\footnotetext{
${ }^{24}$ Marțian 1920, 14, nr. 171; Arhiva Repertoriul Arheologic al României (Arhiva RAR), resursă informaţională disponibilă on-line la adresa http://www.cimec.ro/scripts/ARH/RAR-Index/sel.asp [accesat în 14.12.2012]; RepAB 1995, 163-164

${ }^{25}$ Arhiva RAR; RepAB 1995, 163-164

${ }^{26}$ Horedt 1947-1949, 55-56; RepAB 1995, 185-186, nr. 1

${ }^{27}$ Ciugudean 1997, 148

${ }^{28}$ RepAB 1995, 186, nr. 2

${ }^{29}$ RepAB 1995, 186, nr. 3

${ }^{30}$ RepAB 1995, 186, nr. 4

${ }^{31}$ Ursuţiu 2002, 98-99; vezi supra n. 5.

${ }^{32}$ Horedt 1947-1949, 44-49; RepAB 1995, 186-187
} 
Având în vedere descoperirile databile în perioada Hallstatt-ului mijlociu efectuate în campania 2012 în situl Tărtăria-Podu Tărtăriei vest, credem că este util să amintim o seric de alte puncte din imediata vecinătate unde sunt cunoscute materiale atribuite perioadei culturii Basarabi, respectiv la Pianu de Jos ${ }^{33}$, Unirea ${ }^{34}$ şi Vinţu de $\mathrm{Jos}^{35}$, precum şi depozitele de bronzuri (încadrate în seria Bâlvăneşti-Vinţ/Ha C) de la Blandiana ${ }^{36}$ şi Vinţu I-III ${ }^{37}$. (PI. IV, LIV)

\section{SCURTĂ PREZENTARE A STRATEGIEI DE CERCETARE ARHEOLOGIC̄̃}

Primele etape referitoare la cercetarea sitului Tărtăria-Podu Tărtăriei vest au vizat evaluarea teoretică şi recunoaşterea pe teren, respectiv diagnosticul arheologic propriu-zis constând în efectuarea unor sondaje arheologice, toate aceste lucrări fiind realizate de specialişti din cadrul MNIR în toamna

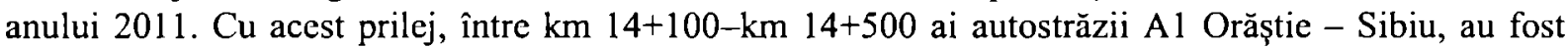
realizate 24 sondaje arheologice (identificate cu siglcle S $511-\mathrm{S}$ 522, S 585-S 589 şi S 592-S 598) ${ }^{38}$. Zona sitului a fost afectată anterior, în cursul secolelor XIX-XX, pe de o parte de lucrări de infrastructură rutieră şi feroviară (traseele DN7 şi DC705E şi cel al căii ferate Alba Iulia-Arad), dar în special de lucrări agricole contemporane (arătură adâncã la aproximativ $0,20-0,30 \mathrm{~m}$ ).

Odată cu inițierea cercetărilor arheologice preventive, în primăvara anului 2012, ținând cont de natura şi caracteristicile sitului, metodologia de lucru a cuprins patru faze principale: faza de documentare, faza de evaluare de teren (periegheză în imediata vecinătate a sitului), cea de cercetare de teren propriu-zisă (săpătură arheologică preventivă) şi cea de analiză şi procesare post-săpătură. Este de remarcat faptul că echipele de lucru şi-au modificat componența de la faza de diagnostic preliminar la cea de diagnostic de teren și apoi la cea de cercetare arheologică preventivă. Pe cale de consecință, faza de documentare, a fost reluată și aprofundată cu ocazia cercetărilor din anul 2012. În principal, s-a avut în vedere realizarea unei documentări de arhivă, pe cât posibil completă, cu privire la diversele categorii de surse istorico-arheologice (texte, fotografii, hărți, schiţe etc.), respectiv identificarea şi verificarea referinţelor bibliografice relevante. În mod evident, s-au adăugat examinări ale unor surse aerofotografice de arhivă şi ortofotoplanuri mai recente, precum şi realizarea unor observaţii directe pe teren (în imediata vecinătate a traseului viitoarci autostrăzi din zona de referință) pentru identificarea altor perimetre susceptibile să conţină vestigii arheologice, având în vedere semnalările anterioare din bibliografia de specialitate.

Pe baza observaţiilor preliminare efectuate şi a materialului arheologic recoltat cu prilejul realizării diagnosticului în teren a fost delimitată o zonă de habitat preistoric, cu urme de locuire databile în epoca bronzului (care odată cu începerea cercetărilor arheologice preventive s-au dovedit a fi din prima epocă a fierului, mai exact perioada Hallstatt-ului mijlociu - epoca stilului ceramic Basarabi). Cu ocazia realizării sondajelor în toamna anului 2011, au fost identificate cinci complexe arheologice (Pl. VIII). De remarcat faptul că sondajele arheologice au fost realizate în absența marcării exacte în teren, de către Beneficiar, a traseului viitoarei autostrăzi. După cum se va vedea în cele ce urmează concluziile studiului de diagnostic arheologic (2011) au fost numai parţial confirmate de cercetările arheologice preventive din vara anului 2012. De asemenea, de amintit și faptul că traseul viitoarei autostrăzi a cunoscut modificări succesive în perioada martie-mai 2012, fapt ce a impus readaptări succesive a strategiei de săpătură.

\footnotetext{
${ }^{33} \operatorname{RepAB} 1995,145-146$

${ }^{34}$ RepAB 1995, 199-200

${ }^{35}$ RepAB 1995, 207-208

${ }^{36}$ Petrescu-Dâmboviţa 1977, 162, pl. 385/1-3, pl. 386/1-6; RepAB 1995, 60-62; Bratu 2009, 238

${ }^{37}$ Pentru depozitul de bronzuri Vinţu I: Soroceanu 1982, 376, nr. 59; Bratu 2009, 371; pentru depozitul de bronzuri Vinţu II: Popa, Berciu 1964, 87-100 (= Popa, Berciu 1965, 51-70); Petrescu-Dâmbovita 1977, 164, pl. 391-393; RepAB 1995, $207-$ 210; Bratu 2009, 371; pentru depozitul de bronzuri Vinfu III: Aldea, Ciugudean 1987, 79-89; Aldea, Ciugudean 1995 , 213-218; Kemenczei 2005, 138, Bratu 2009, 371

${ }^{38}$ Conform raportului de diagnostic arheologic realizat de MNIR şi predat către Ministerul Culturii şi Direcția Județeană pentru Cultură și Patrimoniu Cultural Naţional Hunedoara, documentație de specialitate păstrată în arhiva Secției de Arheologie Pre- şi Protoistorică, Clasică și Medievală - Compartimentul Arheologie Preventivă.
} 
Pornind de la datele furnizate de sondajele arheologice efectuate în toamna anului 2011, în zona iniţială de delimitare a sitului $(14+100$ şi $\mathrm{km} \mathrm{14+500)}$ au fost deschise 16 sectiuni magistrale $\left(\mathrm{S}_{001}-\mathrm{S}_{018}\right)$ pentru a clarifica stratigrafia generală a sitului şi pentru a stabili cu certitudine caracteristicile generale şi densitatea vestigiilor arheologice (PI. IX). Astfel, s-a putut observa preliminar faptul că vestigiile arheologice se concentrau preponderent în zona cuprinsă între km $14+240 / 250$ şi km 14+500; odată cu deschiderea suprafeţelor de cercetare $\left(\mathrm{S}_{\Gamma}-\mathrm{S}_{\mathrm{XI}}\right)$ acest fapt a fost clar confirmat. Dată fiind modificările succesive ale proiectului de construire, limita nordică a zonei de cercetare a fost reamplasată de 3 ori. De asemenea, detalierea proiectului de construire în zona estică a ariei de interes arheologic a necesitat extinderea săpăturii către $E$ (pe întreaga ampriză a autostrăzii), vestigiile descoperite impunând extinderea limitei sitului până spre km 14+540; pe întreaga ampriză a autostrăzii au fost deschise 6 seç̧iuni magistrale $\left(\mathrm{S}_{019}-\mathrm{S}_{025}\right)$, precum şi suprafał̧a de cercetare $\mathrm{S}_{\mathrm{XII}}$ (PI. XIII). Nu în ultimul rând, a existat şi un al treilea motiv al extinderii zonei necesar a fi cercetate, anume aria de relocare a traseului DC705E, respectiv partea nordică a acestuia, de vreme ce porţiunea sa sudică depăşea limita sudică propriu-zisă a sitului ${ }^{39}$. În acest perimetru adiţional de cercetare au fost deschise 6 secţiuni magistrale $\left(S_{026}-S_{031}\right)$ şi o suprafał̧ă de cercetare $\left(S_{X I I I}\right)$, extinderca în suprafaţă a săpăturii arheologice în porţiunea extrem nordică a ariei de relocare a traseului DC705E fiind imposibilă datorită existenţei unei magistrale de gaze (PI. XIV).

Obiectivele campaniei de cercetare arheologică preventivă în teren au constat în stabilirea limitelor sitului, identificarea distribuţiei spaţiale, a caracteristicilor şi elementelor constitutive ale vestigiilor arheologice, cât şi recuperarea tuturor artefactelor şi ecofactelor descoperite pomind de la premisa generală a unei investigații de tipul „salvgardare prin înregistrare”. Odată cu începerea săpăturii propriu-zise, pe măsură ce au apărut o serie de structuri arheologice deosebite, precum elemente de delimitare a habitatului preistoric pe laturile de sud și est, zone cu depuneri (votive ?), respectiv fortificaţia medievală (val cu palisadă) în partea extrem estică a sitului a fost acordată o atenție sporită înregistrării în detaliu a localizării și caracteristicilor acestor vestigii, dar și a materialului arheologic descoperit. Aşa cum am menţionat anterior, s-a putut observa că pe întreaga suprafaţă a sitului depunerile arheologice au fost afectate în partea superioară de intervenţii antropice contemporane. Astfel, obiectivul principal al echipei de arheologi a constat în cercetarea exhaustivă a tuturor vestigiilor delimitate în zona afectată direct de lucrările de construire a autostrăzii, respectiv înregistrarea unor informaţii cât mai detaliate cu privire la structura şi tipologia complexelor/ depunerilor cercetate, prelevarea tuturor artefactelor de interes arheologic, dar şi identificarea altor zone cu potenţial arheologic situate în imediata vecinătate - dar în afara - traseului viitoarei căi rutiere.

Principalele constrângeri existente cu privire la derularea cercetărilor arheologice preventive au fost determinate de mai mulţi factori, în bună măsură de ordin subiectiv. În primul rând a survenit actualizarea repetată a proiectului tehnic de construire a autostrăzii, fapt ce a impus extinderea zonei de cercetare de mai multe ori, cu menţiunea că limitele de expropriere pentru construirea autostrăzii nu au fost materializate în teren în timp optim în raport cu ritmul săpăturii arheologice, în special în prima parte a campaniei arheologice. Un al doilea factor se referă la fluctuaţia constantă a forței de muncă (pusă la dispoziţie de Beneficiar ${ }^{40}$ ) şi numărul muncitorilor raportat la ritmul alert de lucru, dar şi obiectivele şi exigenţele cercetării raportate la structurile descoperite (în special în ceea ce priveşte zona extrem estică a sitului). Alţi factori de ordin subiectiv au în vedere calendarul de lucrări arheologice pe acest tronson şi termenele de lucru ale Beneficiarului, dar şi lipsa unei zone de delimitare acceptabilă între zona de construcţie şi zona de cercetare arheologică (în special începând cu finalul lunii mai şi până la încheierea săpăturii). În fine, un alt factor - de această dată obiectiv este reprezentat de condiţiile meteo (lunile aprilie şi mai fiind deosebit de ploioase).

\footnotetext{
39 Este foarte probabil ca partea de SE a sitului Tărtăria-Podu Tărtăriei vest să fi fost afectată de o serie de clădiri şi amenajări ale unei fabrici de cherestea construită aici după 2005, conform analizei ortofotoplanurilor din perioada 20052012.

${ }^{40}$ Recunoscând faptul că per ansamblu a existat o bună colaborare cu Beneficiarul, dar în diverse momente ale campaniei arheologice au existat deopotrivă inerente şi absolut fireşti discuţii (uneori chiar de pe poziţii adverse) între echipa de arheologi şi echipa STRABAG, dorim să adresām mulţumirile noastre pentru sprijinul acordat domnului director Marius Mitrofan, precum şi domnilor Nicolae Răscol, Alexandru Fazekaş, Reinhard Winkler, Ingo Retter.
} 
Cercetarea arheologică în general, și cu atât mai mult cea preventivă de amploare, necesită gestionarea și documentarea cu acuratețe și precizie, într-un mod standardizat, a datelor înregistrate în teren; acestea cuprind descrierea complexelor/structurilor/contextelor arheologice, documentarea fotografică a acestora și întocmirea unor planuri și hărți care să ilustreze cât mai corect situația din teren ${ }^{41}$. Cartarea (transpunerea prin simboluri grafice și prin culori convenționale, pe hărți topografice) reprezintă cea mai fidelă și precisă modalitate de înregistrare a datelor spațiale ${ }^{42}$, devenind tot mai accesibilă și utilizată în domeniul arheologiei în ultimele decenii. Întregul demers este facilitat de utilizarea Sistemelor Informaționale Geografice ${ }^{43}$ (Geographical Information System - GIS), care permit introducerea, arhivarea, gestionarea și analiza unor informații raportate la coordonate geografice, cu ajutorul calculatorului. Un mare beneficiu al acestei aplicații îl reprezintă posibilitatea de a actualiza constant baza de date asociată, păstrând, atât informațiile vechi, cât și cele noi.

Odată cu începerea săpăturilor arheologice din situl Tărtăria-Podu Tărtăriei vest, o echipă topografică, pusă la dispoziție de către Beneficiar, a efectuat toate ridicările topo în cadrul sitului menționat, ca mai apoi să poată fi integrate toate informațiile înregistrate, pentru procesarea datelor post-săpătură într-o manieră accesibilă și bine organizată. Obiectivul principal al acestui demers a vizat înregistrarea în Proiecția Stereografică 1970 (Stereo 70) a tuturor unităților de săpătură (secțiuni magistrale, suprafețe de cercetare) și a structurilor arheologice investigate utilizând o stație totală, conform cerințelor formulate de arheologii din cadrul echipei de cercetare în teren. Încă de la bun început, echipa de arheologi și echipa de topografi a Beneficiarului, au agreat modalitatea de inregistrare și schimb de date. Astfel, datele au fost măsurate constat, la intervale de aproximativ 5-10 zile (cu excepția primei luni de săpătură), coroborat cu predarea rezultatelor brute către echipa de arheologi în săptămâna imediat următoare efectuării măsurătorilor. În cadrul echipei arheologice, responsabilul științific al șantierului a desemnat - ținând cont de competența în domeniu - un arheolog care a asigurat verificarea și integrarea datelor ${ }^{44}$. Într-o primă fază s-au înregistrat doar unitățile de săpătură (secțiuni magistrale și suprafețe de cercetare) și complexele/contextele arheologice; odată cu extinderea către NE a cercetării în cuprinsul sitului, cu ocazia relocării DC705E a fost proiectat și trasat un sistem de casete, stabilit de echipa arheologică pentru a eficientiza investigarea acestei arii. Astfel, în cazul secțiunilor și a suprafețelor din acest sector, există un set considerabil de coordonate geografice măsurate de la nivelul actual de călcare (toate cotele s-au raportat la nivelul mării) și în diferite faze de extindere, ca în final să fie înregistrată şi cota inferioară (pe lângă detaliile de interes arheologic obținute, astfel pot fi fumizate date certe privind lucrările efectuate, inclusiv calcularea volumului de pământ dislocat). În privința complexelor și a materialul special, s-a avut în vedere colectarea datelor într-o manieră cât mai accesibilă și inteligibilă. Astfel, pentru înregistrarea precisă a conturului complexelor investigate s-au înregistrat de la 2 până la 4 puncte ${ }^{45}$, iar pentru materialul special câte unul, iar în cazuri excepționale (depozite, tezaure, schelete şi resturi osteologice umane) câte 10-20 de puncte. Toate datele obținute, prelucrate și interpretare, au fost suprapuse pe diverse suporturi cartografice, precum așa-numitele ,hărți austriece” (1910, scara 1:200.000) ${ }^{46}$, Planurile

\footnotetext{
${ }^{41}$ Drewett 2011, 54

${ }^{42}$ Renfrew, Bahn 2008, 90

${ }^{43}$ Renfrew, Bahn 2008, 92-95; Westcott, Brandon 2000, 1-2; Drewett 2011, 54-68

${ }^{44}$ Această decizie a fost luată pornind de la standardele de bună practică utilizate la nivel european în ceea ce privește desfăşurarea cercetărilor arheologice preventive, prin punerea în practică a principiului „salvgardării prin înregistrare”.

${ }^{45}$ Pentru exemplificare, modalitatea de lucru în cadrul cercetărilor arheologice preventive derulate în cadrul sitului TărtăriaPodu Tărtāriei vest, a fost următoarea: în urma secționării unui complex a rezultat o axã A-B, care a fost folosită deopotrivă pentru desen şi ridicare topografică, caz în care punctele $\mathrm{A}$ și $\mathrm{B}$ au fost măsurate de la nivelul de conturare și conțin coordonatele $\mathrm{x}, \mathrm{y}, \mathrm{z}$ (unde z reprezintã cota raportată la nivelul mării). Utilizând programul QuantumGIS (program open-source, care nu necesită licență), s-au încărcat punctele A, B, planul scanat al complexului și s-a procedat la georeferențierea celui din urmă (unde punctul $\mathrm{A}$ de pe desen corespunde cu punctul topografic $\mathrm{A}$ etc.). Digitizarea s-a făcut manual, pentru fiecare complex în parte (utilizând "layere" și transpunerea cât mai fidelā în format digital a conturului complexului)

${ }^{46}$ Resursā cartografică disponibilă on-line la http://earth.unibuc.ro/download/harile-austriece-1910-reproiectate-in-stereo70 (accesat la 09.06.2013)
} 
directoare de tragere (perioada interbelică, scara $1: 100.000)^{47}$, Hărțile sovietice (perioada comunistă, scara 1:50.000 și $1: 100.000)^{48}$, Harta Geologică a României (mijlocul anilor '60, scara $\left.1: 200.000\right)^{49}$ și într-o anumită măsură pe ortofotoplanuri (furnizate de Beneficiar), pentru a urmări evoluția în timp a peisajului și construcțiile care ar fi putut afecta situl de-a lungul anilor.

Principalele 3 etape ale evoluției spațiale a săpăturii arheologice preventive în cadrul sitului Tărtăria-Podu Tărtăriei vest au fost:

1. cercetarea în porţiunea (iniţial) delimitată a sitului, respectiv între $\mathrm{km} 14+100$ şi km $14+500$ pe întreaga ampriză a autostrăzii, cu observaţia că limita nordică de expropriere a fost modificată de 3 ori, zona de cercetare fiind extinsă succesiv către N;

2. cercetarea în primul sector adiţional (denumit convenţional sector $\mathrm{E}$ ), respectiv cel estic, aproximativ între km 14+500 şi km 14+540 pe întreaga ampriză a autostrăzii;

3. cercetarca în al doilea sector adiţional, respectiv cel de NE (denumit convenţional sector $\mathrm{NE}$ ), în zona de relocare a DC705E - partea nordică, între metrul 380 şi metrul 620 pe o lăţime de circa $35-40 \mathrm{~m}^{50}$.

Pentru a obţine o imagine cât mai pertinentă referitoare la stratigrafia generală şi natura sitului Tărtăria-Podu Tărtăriei vest în zona delimitată iniţial, prima fază a cercetării arheologice preventive a vizat deschiderea unor secţiuni magistrale pornind de la rezultatele şi descoperirile din etapa de diagnostic arheologic. Astfel, o serie de secţiuni magistrale deschise $\left(\mathrm{S}_{001}-\mathrm{S}_{004}\right)$ au avut în vedere extinderea acelor secţiuni de sondaj (S 511, S 513, S 514, S 585 şi S 588) în care au fost identificate preliminar - vestigii arheologice. Alte sectiuni magistrale $\left(\mathrm{S}_{005}-\mathrm{S}_{018}\right)$ au fost deschise pentru stabilirea certă a distribuţiei spaţiale a vestigiilor arheologice cu scopul de a determina limitele sitului şi în ce măsură acesta urma să fie afectat de lucrările de construire ale viitoarei autostrăzi, respectiv pentru efectuarea unor observaţii referitoare la stratigrafia generală a sitului. De asemenea, odată cu stabilirea limitelor de $\mathrm{E}, \mathrm{S}$ şi $\mathrm{V}$ ale sitului, pornind de la observaţiile făcute în secţiunile magistrale mai sus menţionate au fost deschise o serie de suprafeţe de cercetare $\left(S_{I}-S_{X I}\right)$ în scopul cercetării în detaliu a complexelor/contextelor arheologice. Astfel, a fost infirmată prezenţa vestigiilor arheologice în partea vestică a zonei de interes, aproximativ între km 14+100 şi km 14+240/260, pe întreaga ampriză a viitoarei autostrăzi.

Datele obţinute prin diagnosticul de teren din toamna 2011 şi prima etapă a cercetării din campania 2012 (martie-mai) au putut fị coroborate mai exact, indicând în mod evident o concentrare a locuirii preistorice în zona sudică şi sud-estică a sitului, cu menţiunea că foarte probabil aceasta a fost afectată anterior - începând cu anul 2005 - de construirea unei fabrici de cherestea, ale cărei clădiri şi amenajări existau la momentul începerii săpăturii.

Una dintre cele mai importante observaţii efectuate în această etapă a săpăturii a fost cea referitoare la existenţa unei viroage în limita sudică a sitului, o structură naturală cu urme de intervenţie antropică care a fost interpretată (preliminar) ca fiind un şanţ de delimitare a zonei de habitat preistoric. Practic aceasta constituie limita de $\mathrm{S}$ a sitului, traseul său fiind observat pe direcţia V-E pe o distanţă de peste $250 \mathrm{~m}^{51}$; dincolo de aceasta, pe platoul către satul Tărtăria, în limita de

47 Resursă cartograficà disponibilă on-line la http://earth.unibuc.ro/download/planurile-directoare-de-tragere (accesat la 09.06.2013)

48 Resursã cartografică disponibilă on-line la http://earth.unibuc.ro/download/hartile-sovietice-50k; http://earth.unibuc.ro/download/hartile-sovietice-1-100-000-reproiectate-in-stereo70 (accesat la 09.06.2013)

${ }_{49}$ Resursă cartografică disponibilă on-line la hittp://earth.unibuc.ro/download/harta-geologica-a-romaniei-scara-l-200-000 (accesat la 09.06.2013)

so Cercetarea arheologică preventivă la $\mathrm{S}$ de limita de expropriere pentru tronsonul principal al autostrăzii, respectiv în porţiunea sudică a zonei de relocare a DC705E nu s-a justificat de vreme ce respectiva porţiune de teren fusese deja afectată foarte recent de construcţii, în perioada 2005-2012.

${ }^{51}$ Iniţial această structură a fost identificată în partea vestică a zonei iniţiale de cercetare, fiind identificată cu sigla CPL 004 . Ulterior, în colţul de SE al zonei iniţiale de cercetare a fost observată o altă structurā liniarã care a primit sigla CPL 118 . În 
expropriere a autostrăzii nu au mai fost observate nici un alt fel de indicii cu privire la prezenţa potenţialului arheologic (PI. IX, X). Aceasta este o structură cu caracteristici aparte, atât din punct de vedere natural (prezenţa a numeroase izvoare), cât şi arheologic (depuneri votive aparte databile în perioada culturii Basarabi / Ha C - depozite de bronzuri, piese de metal, vase întregi/întregibile şi fragmente de schclete umane). De asemenea, există două descoperiri ulterioare momentului depunerilor din perioada hallstattiană, anume în partea superioară a acestei structuri au fost descoperite un tezaur monetar databil în perioada Latène şi o fibulă de bronz databilă în epoca romană. Tot în acest stadiu al săpăturii a fost stabilit clar faptul că situl continuă spre $\mathrm{N}$, către valea Mureşului, numai partea sa sudică fiind afectată de lucrările de construire a autostrăzii.

În ceea ce priveşte prima zonă adiţională de cercetare (sector $E$ ), strategia de săpătură a avut în vederc deschiderea unor secţiuni magistrale de sondaj care să ,taie” panta estică a terasei în vederea stabilirii prezenţei sau absenţei potenţialului arheologic în ampriza autostrăzii între km $14+500$ și km $14+540$. În prima secţiune de sondaj deschisă în acest perimetru $\left(S_{019}\right)$ a devenit mai mult decât evident faptul că vestigiile arheologice continuau să existe şi în această direcţie, fiind descoperite urmele unei fortificaţii (val cu palisadă, incendiată şi şanţul adiacent, în bună măsură distrus de amenajarea actualului DC705E) (PI. XXI, XXII). În continuare au fost deschise alte 5 secţiuni magistrale de sondaj $\left(\mathrm{S}_{020}-\mathrm{S}_{025}\right)$ - orientate aproximativ $\mathrm{V}-\mathrm{E}$, perpendicular pe marginea terasei amintite - care să ofere cât mai multe date despre structura şi caracteristicile fortificaţiei. De asemenea, acestea au furnizat indicii foarte clare cu privire la faptul că stratul de cultură preistoric (Hallstatt mijlociu/perioada c. Basarabi) continua până la limita estică a terasei. Nu în ultimul rând, a fost observată existenţa unui al doilea şanţ preistoric (CPL 155), orientat aproximativ pe direcţia NNV-SSE. Toate acestea au condus la deschiderea unei suprafețe de cercetare $\left(S_{X I I}\right)$ în vederea obţinerii unei imagini de ansamblu asupra distribuţiei şi caracteristicilor complexelor arheologice din această zonă. (PI. IX, XIII)

În cuprinsul celei de-a doua zonei suplimentare de cercetare (sector $\mathrm{NE}=$ zona de relocare a DC705E) obiectivele cercetării au vizat stabilirea existenţei sau absenţei nivelului de locuire hallstattian, dar şi identificarea traseelor şanţului estic (preistoric) şi a fortificaţiei cu palisadă incendiată. S-a optat, de asemenea, pentru o serie de sondaje magistrale, amplasate, atât pe limita vestică de expropriere a acestei zone $\left(S_{026}\right)$, cât şi pe marginea estică a terasei $\left(S_{02}-S_{031}\right)$. După obţinerea unor informaţii stratigrafice preliminare, s-a procedat la caroierea întregului perimetru accesibil cercetării şi deschiderea unei suprafeţe de cercetare $\left(S_{X I I I}\right)$ cuprinzând 12 casete de cercetare $\left(C_{1}-C_{12}\right)$. Trebuie amintit că partea extrem nordică a zonei de relocare nu a putut fi cercetată în suprafaţă datorită existenţei unei magistrale de gaze. Totuşi în această zonă au fost deschise două secţiuni magistrale de sondaj $\left(\mathrm{S}_{030}-\mathrm{S}_{031}\right)$, orientate $\mathrm{V}-\mathrm{E}$, tăind marginea estică a tcrasei; urmele incendiate ale fortificaţici erau vizibile în profilele ambelor sondaje, însă stratul de cultură hallstattian nu a mai fost observat. (PI. IX, XIV)

Date find caracteristicile sitului (stabilite în linii generale pe parcursul primei luni de săpătură, odată cu deschiderea primelor secţiuni magistrale de sondaj $S_{001}-S_{009}$ şi a suprafeţelor de cercetare $S_{I}-S_{V}$ ), timpul (iniţial planificat pentru circa 10-12 săptămâni, ulterior extins la peste 18 săptămâni de lucru efectiv în teren, cu un program de lucru de 6 zile pe săptămână, 10 ore zilnic cu excepţia zilelor de ploaie) şi logistica avută la dispoziţie (echipă de muncitori cu un efectiv mediu de circa 16-20 persoane, un excavator cu cupă de taluz lată şi un camion) s-a optat pentru efectuarea decapării exclusiv cu mijloace mecanice. Astfel, a fost posibil ${ }^{52} \mathrm{ca}$ - în timpul avut la dispoziţie şi cu

\footnotetext{
contextul cercetării în suprafaţă a devenit clar faptul cã CPL 004 este continuat de CPL 118, însã având în vedere faptul că în partea sa estică structura a fost afectată de constructiile industriale contemporane am optat pentru mentinerea celor două sigle. Date fiind dimensiunile şi caracteristicile structurii, calendarul de lucrări şi logistica avută la dispoziţie (forţă de muncā şi utilaje) s-a optat pentru efectuarea unor sondaje transversale, respectiv în partea esticā (CPL 118) unde prezenţa materialelor arheologice era sporadică au fost deschise 9 sondaje, iar în partea vestică (CPL 004) unde materialele arheologice erau deosebite ca număr şi natură au fost deschise 23 de asemenea sondaje. Aceste sondaje au fost săpate atât cu mijloacc mecanice, cât şi manual. Acestora li se adaugă două secţiuni magistrale, respectiv $\mathrm{S}_{003}$ nord şi $\mathrm{S}_{008}$ sud, ambele intersectând - aproximativ perpendicular - traseul CPL 004.

52 Dincolo de implicarea echipei de arhcologi şi sprijinul acordat de firma STRABAG, cercetarea acestui sit a fost posibilă şi datorită unor oameni simpli însă foarte inimoşi, anume şefii echipei de muncitori (Ioan Varga şi Marius Mezei), excavatoriştii (Ion Danciu și Dumitru Groze), cât şi unii dintre muncitori (Ana, Edith, Şoni, Piki, Tibi, Ion şi Iosif), astfel că dorim să le mulţumim şi cu acest prilej.
} 
logistica existentă - să fie deschisă în suprafaţă pentru cercetare o arie de circa 2 ha (valoare însumată pentru toate cele 3 sectoare ale sitului) şi complexele arheologice să fie săpate manual, până la nivelul solului viu, cu excepția a 6 complexe/contexte (CPL 004/CPL $118=$ şanţ sudic preistoric, CPL $151=$ fortificaţia medievală cu palisadă incendiată, CPL 153 = strat de cultură hallstattian în extremitatea estică a sitului, CPL $155=$ şanţul estic preistoric, CPL $156=$ strat de cultură hallstattian în extremitatea estică a sitului și CPL 258).

Tinând cont de situaţia existentă în teren, săpăturile arheologice au fost organizate printr-o cercetare în suprafaţă (open area excavation), într-o abordare metodologică adaptată unei serii întregi de factori. Pe întreaga porţiune cercetată din situl Tărtăria-Podu Tărtăriei vest, datorită termenelor contractuale, dar ţinând seama şi de observaţiile stratigrafice, decaparea s-a efectuat mecanic utilizând două tipuri de excavatoare, ambele având cupă lisă (de taluz), fapt care a permis obţinerea unor răzuieli cu acurateţe suficientă pentru a identifica şi delimita complexele. Având în vedere observațiile realizate în secțiunile magistrale de sondaj, a fost decapată întreaga suprafaţă a sitului aflată pe traseul autostrăzii până la limita nordică de expropriere, păstrând diverși martori stratigrafici, ulterior demontaţi, care separau iniţial suprafeţele de cercetare. De notat faptul că limita sudică a sitului a fost clar observată în porțiunea mediană a traseului autostrăzii (PI. XI). De asemenea, a putut fi clar stabilit faptul că limita vestică a sitului este situată în afara traseului viitoarei autostrăzi, neexistând practic vestigii arheologice între km 14+100 şi km 14+240/250.

În general, contextele au fost delimitate mai ales către limita dintre stratul de sol negru şi depunerea de argilă galbenă. De remarcat faptul că în numeroase cazuri complexele se conturau imediat sub stratul vegetal. În stratul negru, în lipsa materialului sau lentilelor de cenuşă sau de argilă din umplutură, a fost dificil de delimitat forma gropilor. S-au conturat astfel aşa-numite resturi de strat de cultură, unde existau concentrări de material ceramic fragmentar, acestea fiind săpate manual. Stratul vegetal, având grosimi diferite în diverse porțiuni ale sitului, a fost decapat exclusiv cu mijloace mecanice. Doar în cazul a șase vestigii (menționate anterior) acest fapt a fost imposibil datorită dimensiunilor acestora și resurselor avute la dispoziție. S-a încercat - pe cât posibil reducerea perioadei dintre identificarea complexelor în urma decapării mecanice şi cercetarea lor propriu-zisă. Astfel, toate complexele/contextele arheologice identificate au fost săpate manual, cu efectuarea ritmică a observaţiilor şi înregistrărilor arheologice şi topografice. Metoda folosită pentru delimitarea complexelor a constat în serii de răzuieli succesive realizate manual, care au urmat decapării solului vegetal actual cu mijloace mecanice, sub strictă supraveghere arheologică.

După decapare, complexele au fost răzuite manual, au primit siglă de complex şi au fost descrise preliminar. O dată delimitate, complexele au fost mai întâi fotografiate, apoi desenate la scara $1 / 20$, cu excepţia unor detalii precum dispunerea obiectelor în umplutura unor gropi, care au fost înregistrate la scara $1 / 10$. În acelaşi timp, localizarea complexelor a fost înregistrată cu staţia totală, datele fiind ulterior integrate în planul general de către un arheolog din echipa de cercetare $^{53}$; s-a încercat, pe cât posibil, asigurarea unui schimb constant de date cu echipa topografică pusă la dispoziție de către Beneficiar. Etapa următoare a cercetării a constat în secţionarea complexelor. Pe întreaga suprafată cercetată a sitului au fost descoperite mai multe tipuri de complexe, aparţinând (cu trei excepții) habitatului hallstattian: posibile bordeie/locuinţe semi-adâncite (poate mai corect spus construcţii semi-adâncite), gropi menajere (structuri de tip refuse pit), gropi de ofrandă (conţinând mai multe vase întregi/întregibile), gropi de provizii şi gropi fără funcţionalitate certă. Acestora li se adaugă descoperirile cu caracter deosebit (depozitele Tărtăria I și II, mormântul colectiv, dar și șanțul sudic de delimitare în care au fost observate depuneri cu caracter aparte - fragmente de schelete umane, vase întregi/întregibile și piese de metal). S-a încercat, pe cât posibil ca gropile să fie secţionate de-a lungul diametrului maxim; în general, s-a urmărit săparea lor pe contur. După înregistrarea prin fotografie şi desen a profilului s-a procedat la săparea celeilalte jumătăţi a gropilor.

Pentru gestionarea eficientă a datelor, inclusiv pentru introducerea acestora în proiectul GIS, au fost utilizate - încă de la începerea săpăturii - fişe standard pentru unitățile de săpătură, complexe arheologice şi material special (vase întregi/întregibile, piese de metal, piatră prelucrată etc.). De asemenea, în ceea ce priveşte modalitatea de înregistrare a informaţiilor, au fost folosite metode

\footnotetext{
${ }^{53}$ Este de remarcat faptul cā echipa de cercetare a sitului Tărtăria-Podu Tărtăriei vest a avut un atú deosebit prin expertiza domnului Vlad Rumega în domeniul topografiei arheologice.
} 
descriptive uzuale în arheologie, texte descriptive, desene - grund şi profil, fotografii, măsurători altimetrice şi topografice etc. Astfel, au fost realizate planuri şi profile (generale şi de detaliu), cât şi fotografii in format digital pentru diferitele stadii de cercetare ale complexelor (conturare/secţionare/finalizare).

Tinând cont de toate acestea, la încheierea cercetărilor - desfăşurate pe o perioadã de aproximativ 4 luni şi acoperind o suprafałă de aproximativ 5 ha, din care circa 2 ha reprezentând săpătură arheologică în suprafał̧ă deschisă - s-a trecut la următoarea etapă, anume cea a documentării şi analizei preliminare post-săpătură.

Desigur, odată cu finalizarea cercetării arheologice în teren, cel mai important demers îl reprezintă procesarea datelor post-săpătură a datelor referitoare la vestigiile arheologice cercetate ${ }^{54}$, precum şi conservarea-restaurarea ${ }^{55}$ si inventarierea bunurilor arheologice mobile. Dată fiind amploarea cercetărilor în teren şi natura sitului, cantitatea de material arheologic rezultată este impresionantă. Ori, în conformitate cu principiile şi practicile ce definesc o cercetare arheologică, obiectivele strategice referitoarc la salvgardarea patrimoniului arheologic în contextul unei abordări de tip ,păstrare prin înregistrare” sunt atinse numai prin derularea adecvată a unor asemenea activităţi, care vizează evidenţa patrimoniului arheologic mobil (inclusiv clasarea unora dintre bunurile descoperite) şi valorificarea rezultatelor cercetărilor, în special prin publicarea acestora (prin articole, studii sau chiar volume cu caracter monografic). Deși a trecut aproape un an şi jumătate de la incheierea cercetărilor arheologice preventive de la Tărtăria-Podu Tărtăriei vest, procesul de restaurare a materialului arheologic este încă departe de a fi încheiat. Acest fapt se datorează, pe de o parte, cantității și complexității descoperirilor (în special dacă ne referim la piesele de bronz și fier din depozitele Tărtăria I și II, dar şi a celor din inventarul complexelor investigate), iar pe de altă parte capacității limitate a unor instituții muzeale - fie ele chiar de rang național - de a gestiona descoperiri dc asemenea amploare.

\section{DATE GENERALE PRIVIND STRATIGRAFIA SITULUI}

Pornind de la observaţiile efectuate pe profilurile secţiunilor magistrale deschise în diverse puncte ale sitului a putut fi stabilită secvenţa stratigrafică generală a zonei investigate. În urma deschiderii sondajelor şi cercetării suprafeţelor arheologice s-a putut observat prezenţa mai multor niveluri având caracteristici variabile în funcţie de morfologia terenului. Ținând cont de diversitatea lor pe întreaga suprafał̧ă a sitului a fost selectat pentru exemplificarea stratigrafiei generale profilul magistral de $\mathrm{N}$ al suprafețelor $\mathrm{S}_{\mathrm{IX}}, \mathrm{S}_{\mathrm{VIII}}, \mathrm{S}_{\mathrm{IV}}, \mathrm{S}_{\mathrm{VII}}, \mathrm{S}_{\mathrm{VI}}, \mathrm{S}_{\mathrm{III}}, \mathrm{S}_{\mathrm{II}}$ şi $\mathrm{S}_{\mathrm{I}}$, care porneşte de la $\mathrm{km} 14+220$ şi se opreşte la km 14+500, fiind ilustrată porţiunea dintre km 14+360 şi km 14+440 (Pl. XIX). Totodată trebuie menţionat faptul că km 14+220 coincide cu cea mai înaltă cotă $(237,75 \mathrm{~m}$ de la nivelul mării) a porţiunii cercetate din sit. Din acest punct şi până la km 14+540 panta are o cădere de $10 \mathrm{~m}$, cotă măsurată la nivelul actualului drum comunal DC705E.

Pe întreaga lungime mai sus menţionată, stratul de sol vegetal are grosimi ce variază între 0,05 $\mathrm{m}$ şi $0,40 \mathrm{~m}$. Pe alocuri, datorită lucrărilor agricole s-au observat fragmente ceramice, bucăţi de chirpici şi piese metalice chiar în componenţa acestuia. Următorul strat are o grosime constantă de 0,40-0,60 m fiind reprezentat de un sediment negru compact, pigmentat destul de puternic cu fragmente de chirpici şi având un conţinut ridicat de material arheologic. Acesta corespunde cu ceea

\footnotetext{
${ }^{54}$ Procesarea datelor post-săpătură este, în chip firesc, un demers colectiv, realizat după cum urmeazā: arhiva documentară de cercetare \& baze de date - Corina Borş, Luciana Irimuș, Vlad Rumega; topografie arhcologică şi cartări - Vlad Rumega; trierc matcrial ceramic - Luciana Irimuş, Vlad Rumega; studiu ceramică - Luciana Irimuş, Corina Borş; studiu picse de metal - Corina Borş; evidență materiale arheologice - Corina Borş, Luciana Irimuş, Marius Streinu (2013); desen material arheologic - Luciana Irimuș (ceramică), Sebastian Dobrotă (2012 - ceramică), Alexandra Dolea (2012 - ceramică), Alina Muşat (2012 - ceramică), Georgiana Ducman (2013 - piese metal); fotografii piese arheologice - Marius Amarie, Luciana Irimuș, Vlad Rumega.

Ss Dorim şi pe accastã cale sã mulțumim în mod deosebit doamnclor Gabriela Dragomir şi Ileana Zahariade - restauratori ceramică, doamnei Mariana Rogojină - restaurator metal și domnilor Francisc Dozsa şi Alexandru Dozsa - restauratori metal și mai tinerilor lor colaboratori: Mădălina Voicu, Radu Bălănescu, Mihai Duca și Paul Popa pentru activitatea lor legată de restaurarea lotului de material arheologic provenit din situl Tărtăria-Podu Tărtăriei vest.
} 
ce poate fi identificat drept „stratul de cultură” hallsttatian. Per ansamblu, sub stratul preistoric de cultură a fost observată existența solului galben, steril din punct de vedere arheologic.

Începând cu km 14+350 şi până la km 14+430 s-a observat existenţa unui strat de pământ maron-cenuşiu, situat între stratul de sol negru (= strat de cultură) şi solul galben, acesta adâncindu-se până la $-2,00 \mathrm{~m}$ (raportat la nivelul actual de călcare în punctul maxim, înregistrat în suprafaţa de

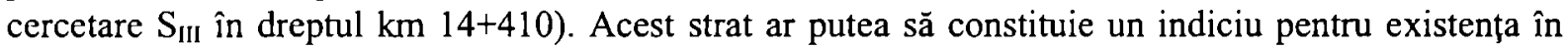
trecut a unei zone mlăștinoase/umede care se întindea, atât spre $S$, depăşind suprafaţa de cercetare $S_{V}$ şi şanțul preistoric sudic (identificat cu sigla CPL 004/CPL 118), cât şi spre N în zona neafectată de lucrările de construire a autostrăzii. În suprafał̧a de cercetare $S_{V}$ acest strat are o pigmentaţie feruginoasă, datorată - cel mai probabil - descompunerii în timp a florei acvatice (stuf, papură). (Pl. $\mathbf{X X )}$

Pe traseul acestei alveolări, în zona profilului nordic al $S_{V I}$ și $S_{I I l}$, în 3 puncte aflate la 8-10 m distanţă unul de celălalt s-au efectuat sonde cu mijloace mecanice până la $3 \mathrm{~m}$ adâncime; în partea inferioară a acestora a fost vizibil stratul nativ de pietriş. Din punct de vedere pedologic, zona în discuţie este încadrată cemoziomurilor argiloiluviale tipice ${ }^{56}$. (PI. XIX)

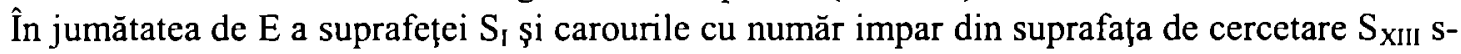
a observat absenţa aproape în totalitate a stratului de cultură, motiv care ar explica şi raritatea complexelor în această porţiune a sitului. Cel mai probabil, în această parte a sitului lucrările agricole au afectat cvasi-integral depunerea arheologică, dacă ţinem cont de faptul că înspre E stratul de cultură hallstattian reapare. De asemenea, este de menţionat faptul că observaţiile efectuate pe profilul magistral estic al suprafeței S I (= secţiunea magistrală $S_{001}$ trasată perpendicular pe axul viitoarei autostrăzi în dreptul $\mathrm{km} \mathrm{14+500)} \mathrm{nu} \mathrm{indicau} \mathrm{continuarea} \mathrm{locuirii} \mathrm{spre} \mathrm{E.} \mathrm{Ulterior} \mathrm{în} \mathrm{zona}$ corespondentă, chiar pe limita estică a terasei pe care este situat situl, către traseul actual al DC705E sa dovedit că există o continuare a locuirii preistorice (hallstattiene) suprapusă de urmele incendiate ale unei fortificaţii medievale (CPL 151).

În urma deschiderii mai multor sondaje $\left(\mathrm{S}_{019}-\mathrm{S}_{025}, \mathrm{~S}_{027}-\mathrm{S}_{031}\right)$ pe traseul acestei fortificaţii s-a observat prezenţa unui val de pământ cu palisadă incendiată, iar şanţul ce va fí existat imediat la $\mathrm{E}$, a fost afectat în mare măsură de construirea drumului comunal DC705E. Sub nivelul fortificaţiei, stratul de cultură hallsttatian are grosimi variabile. În acest nivel au fost conturate mai multe complexe, inclusiv un şanţ în formă de „V” (CPL 155), orientat aproximativ NNV-SSE cu o lăţime de 1-1,40 m.

\section{(PI. XXI-XXIII)}

În ceea ce priveşte şanţul preistoric sudic (CPL 004/CPL 118) a putut fi stabilit cert că acesta delimitează situl pe latura sa de S (PI. XI, XII, XVI). Umplutura sa era compusă din pământ negrucenuşiu, închis, cu pigment de chirpici. În funcţie de caracteristicile terenului, în profilurile transversale ale multiplelor sondaje perpendiculare efectuate pe traseul său ${ }^{57}$ au fost realizate observaţii de detaliu care indică în diverse puncte micro-straturi de textură, cromatică şi grosimi diferite. Per ansamblu, forma şanţului în secţiune este convexă, având o deschidere maximă de 5-6 m şi o adâncime ce variază între 1,50 şi $1,80 \mathrm{~m}$ de la nivelul actual de călcare, cu menţiunea că în suprafaţa $\mathrm{S}_{\mathrm{IV}}$ acesta este mai puţin adânc. Pe traseul şanţului au apărut multiple infiltraţii de apă (izvoare naturale ?) care puteau alimenta şanţul în mod natural, menţinând constant un mediu umed. Către limitele de $\mathrm{V}$ şi de $\mathrm{E}$ ale sitului s-a putut observa că fundul şanţului străpungea straturile de pietriş nativ. (PI. XX, XXIV-XXVIII)

Având în vedere cel puţin două descoperiri ulterioare nivelului de depuneri hallstattiene, respectiv tezaurul monetar databil în secolele II-I a. Chr. găsit în extremitatea sa vestică ( $\mathrm{S}_{\mathrm{VIII}}$, sondaj

\footnotetext{
${ }^{56}$ Date conţinute de Harta Geologică a României (scara 1:200.000), realizată de Institutul Geologic al României, disponibilă on-line la adresa http://earth.unibuc.ro/download/harta-geologica-a-romaniei-scara-1-200-000 (accesatā în data de 20.01.2013).

${ }^{57} \mathrm{Pe}$ traseul CPL 004/CPL 118 , de la V la E au fost efectuate 34 de sondaje transversale dupã cum urmează: în suprafała $S_{\text {VIII }}$ - sondajele CPL $004 \mathrm{C}, \mathrm{X}, \mathrm{Y}, \mathrm{D}$ (4 sondaje); în suprafaţa $\mathrm{S}_{\mathrm{IV}}$ - sondajele CPL $004 \mathrm{Q}, \mathrm{H}, \mathrm{R}, \mathrm{G}, \mathrm{F}, \mathrm{S}, \mathrm{T}, \mathrm{I}, \mathrm{U}, \mathrm{V}, \mathrm{J}$ (11 sondaje); secţiunea magistrală $\mathrm{S}_{003}=\mathrm{CPL}$ 004A (acesta este primul sondaj pe traseul şanf̧ului deschis încă din etapa de diagnostic 2011, ulterior fiind extins); în suprafaţa $S_{V I I}$ - sondajele CPL $004 \mathrm{~N}, \mathrm{E}, \mathrm{O}, \mathrm{P}, \mathrm{P} 1$ (5 sondaje); în suprafał̧a $S_{\mathrm{V}}-$ sondajele CPL $004 \mathrm{M}, \mathrm{L}, \mathrm{K}$ (3 sondaje); secţiunea magistralā $\mathrm{S}_{008}$ sud reprezintã cel mai vestic sondaj pe traseul CPL 118; în suprafaţa $S_{I I I}$ - sondajele CPL $118 \mathrm{I}, \mathrm{H}, \mathrm{G}, \mathrm{F}$ (4 sondaje); în suprafeţele $\mathrm{S}_{\mathrm{II}}$ şi $\mathrm{S}_{\mathrm{I}}$ - sondajele CPL $118 \mathrm{C}, \mathrm{D}, \mathrm{A}, \mathrm{B}, \mathrm{E}(5$ sondaje). (PI. X)
} 
CPL 004D) şi o fibulă de bronz datând din epoca romană descoperită în porțiunea sa mediană ( $S_{V I I}$, sondajul CPL 004P), se poate avansa ca ipoteză de lucru posibilitatea ca acest şanţ sudic să fi fost vizibil la peste cinci secole faţă de orizontul cronologic al depunerilor atribuite perioadei Hallstatt-ului mijlociu ( $\mathrm{Ha} \mathrm{B}_{3}-\mathrm{C}$, secolele IX-VIII a. Chr., perioada stilului ceramic Basarabi).

\section{SCURTÃ PREZENTARE A DESCOPERIRILOR ARHEOLOGICE}

Într-o descriere preliminară sumară, majoritatea descoperirilor arheologice din cadrul sitului Tărtăria-Podu Tărtăriei vest aparţin unui habitat preistoric delimitat (?) pe laturile de S şi E. Trebuie însă precizat faptul că în ceca ce privește șanțul sudic preistoric nu au fost surprinse indicii în legătură cu structuri defensive complementare precum un val sau o palisadă; în aceste condiţii stabilirea funcţionalităţii acestei structuri, respectiv caracterul per ansamblu al sitului preistoric constituie obiective ale cercetărilor ulterioare. De asemenea, absenţa unor elemente constructive de tipul pereţilor, podinelor, vetrelor etc. in situ, dar şi a gropilor de par în cazul majorităţii complexelor cercetate, precum şi numărul mare de vase întregi/întregibile asociate cu un număr mare de piese de metal (bronz şi fier) ne fac să fim rezervaţi - cel puţin pentru moment - în stabilirea funcţionalităţii certe a structurilor investigate, în special în sensul interpretării lor ca urme ale unor locuinţe. Acestor observaţii li se adaugă cele trei descoperiri cu caracter exceptional efectuate în partea sudică a sitului, anume două depozite de bronzuri ${ }^{58}$ (încadrabile în aşa numita serie Bâlvăneşti-Vinţ / Ha $\mathrm{C}^{59}$ ) (Pl. XXXIX-XL, L-LIII) şi un posibil mormânt (?) colectiv ${ }^{60}$ (CPL 114), conţinând 6 schelete şi un craniu, asociate cu ceramică specifică stilului Basarabi şi mici piese de bronz şi fier (PI. LIX-LX). Astfel, este clar faptul că - inclusiv în acest stadiu incipient al procesării datelor post-săpătură descoperirile databile în perioada Hallstatt-ului mijlociu sugerează că situl Tărtăria - Podu Tărtăriei vest este unul cu totul aparte în cadrul repertoriul descoperirilor de tip Basarabi. În acest sens sunt de luat în considerare cele peste 150 de vase întregi/întregibile descoperite în inventarele unor complexe (PI. XXXVI-XXXVIII), cele peste 100 de piese de metal (întregi şi fragmentare) ${ }^{61}$ descoperite în acelaşi context, raportat la stadiul actual al cercetărilor cu privire la perioada stilului ceramic Basarabi în spaţiul intracarpatic şi, în general, în bazinul carpatic al Dunării. Sunt de asemenea de remarcat numeroasele vase cu decor specific acestui stil ceramic, varietatea lor tipologică, dar şi cantitatea foarte mică de oase de animal. Un alt factor de natură să determine o abordare prudentă în ceea ce priveşte stabilirea tipului de sit şi funcţionalitatea marii majorităţi a complexelor cercetate este determinat de gradul semnificativ de perturbare antropică contemporană a părţii superioare a depunerilor arheologice.

Totuşi, în stadiul actual de analiză a materialului arheologic descoperit pot fi formulate succinte consideraţii preliminare asupra categoriilor funcţionale ale structurilor cercetate. Astfel, per ansamblu complexele arheologice cercetate pot fi încadrate în următoarele categorii: (posibile) bordeie/locuinţe semi-adâncite (poate mai corect spus construcţii semi-adâncite), gropi menajere (structuri de tip refuse pit), gropi de ofrandă (conţinând mai multe vase întregi/întregibile), gropi de provizii şi gropi fără funcţionalitate certă. Se adaugă descoperirile cu caracter deosebit, respectiv cele două depozite de bronzuri, depunerea funerară (mormânt ?) colectiv(ă), şanţul sudic preistoric (în care au fost descoperite mai multe vase întregi/întregibile, piese de metal şi resturi de schelete umane) (PI. XVI) şi fortificaţia cu palisadă incendiată, databilă în perioada Evului Mediu timpuriu.

\footnotetext{
${ }^{58} \mathrm{Cu}$ privire la caracterul de unicitate a acestei descoperiri raportat la stadiul actual al cercetării, vezi pagina următoare și infra secțiunea Concluzii.

${ }^{59}$ Rusu 1963, 177-210; Pctrescu-Dâmbovita 1977, 161-164; Metzner-Nebelsick 2005, 327-328

${ }^{60}$ În stadiul actual al cercetării, cele mai apropiate analogii pentru aceastā descoperirc par a fi celc douã morminte (depuneri funerare) colective de la Gomolava; pentru detalii, vezi Tasić 1972; Tasić 2004, 11.

${ }^{61}$ Este de remarcat - chiar şi în stadiul preliminar de procesare şi analiză post-săpătură a datelor - numărul de câteva ori mai mare al pieselor de metal (întregi şi fragmentare) provenite din inventarele unor complexe din situl Tărtăria raportat la cele cinci piese de metal (bronz şi fier) - cunoscute anterior anului 2012 - asociate descoperirilor de ceramicà de tip Basarabi în aria intracarpatică; pentru detalii în acest sens, vezi Ursuţiu 2002, 57-60.
} 
Cercetarea arheologică efectuată în perioada martie-iulie 2012 pe traseul autostrăzii Al: Orăştie-Sibiu, lot 1, în raza administrativă a satului Tărtăria (com. Săliştea, jud. Alba), punct Podu Tărtăriei vest, a condus la investigarea completă a zonei afectate de viitoarele lucrări de construire a autostrăzii A1 din cuprinsul sitului arheologic A1-OS1/sit 7 (km 14+100-14+540 şi zona nordică de relocare a DC705E), astfel fiind delimitate şi cercetate 269 complexe şi contexte arheologice. În condiţiile şi circumstanţele prezentate a fost cercetat integral tot perimetrul ce urma să fie afectat de lucrările de construire ale autostrăzii şi relocarea drumului comunal menționat. Analiza distribuţiei spaţiale a complexelor arheologice şi observaţiile stratigrafice indică în mod cert faptul că situl este numai parţial afectat de construirea autostrăzii pe latura sa sudică şi estică, astfel că la nord de traseul acesteia rămân porţiuni importante din acesta. (PI. XI, XV, XIX)

Cercetarea arheologică preventivă prezentată a confirmat numai parţial datele preliminare furnizate de studiul de diagnostic arheologic (teoretic şi de teren) din anul 2011. Astfel, în cazul de faţă este vorba de un sit cu un singur nivel de locuire pentru cea mai mare parte din suprafaţa sa (excepţie făcând zona sa extrem estică), depunerea arheologică fiind semnificativ afectată de intervenţii antropice recente (în special lucrări agricole); observaţiile stratigrafice şi materialul arheologic descoperit (ceramică, piese de metal) nu susţin ipoteza, formulată prin studiul de diagnostic din toamna anului 2011 , conform căruia în cadrul sitului ar fi existat urme de locuire încadrabile în epoca bronzului.

Analiza preliminară a materialului arheologic descoperit (ceramică, piese de metal) arată faptul că - din punct de vedere cronologic - această staţiune preistorică (aşezare/arie de depunere ?) se datează în perioada Hallstatt-ului mijlociu, respectiv perioada stilului ceramic Basarabi $\left(\mathrm{Ha}_{3}-\mathrm{C}\right.$, secolele IX-VIII a. $\mathrm{Chr}^{62}$ ), fiind de subliniat prezenţa în inventarul complexelor a numeroase vase ceramice întregi şi întregibile (atât ceramică decorată, dar şi vase de uz comun) şi piese din bronz şi fier (întregi sau fragmentare).

Cele mai importante descoperiri arheologice efectuate în cadrul sitului Tărtăria-Podu Tărtăriei vest sunt indicate succint în cele ce urmează.

CPL 116 - Depozitul Tărtăria I. Acesta constituie cel mai mare şi complex depozit de piese de bronz şi fier databil la nivel de $\mathrm{Ha} \mathrm{C}_{1}$ (aparţinând aşa-numitei serii Bâlvăneşti-Vint/respectiv orizontul de depuneri de bronzuri VI = DFS $\mathrm{VI}^{63}$ ) descoperit în zona actuală a României şi - destul de probabil $^{64}$ - din zona arcului carpatic şi a bazinului Dunării Mijlocii şi de Jos. De asemenea, este cel dintâi depozit din acest orizont cronologic găsit într-o săpătură arheologică la nivelul ţării noastre; conţine peste 300 de piese - arme, unelte, piese de port şi de harnaşament - inventariate preliminar până în acest moment şi intrate în restaurare, fiind de aşteptat ca la finalizarea acestui proces să fie identificate peste 400 de piese per total. (PI. XXXIX, L-LII)

CPL 122 - Depozitul Tărtăria II. Şi acesta se datează, de asemenea, la nivel de $\mathrm{Ha} \mathrm{C}_{1}$, respectiv este încadrabil în aşa-numita serie Bâlvănești-Vinţ/orizont VI de depuneri de bronzuri = DFS VI. Este cel de-al doilea depozit din acest palier cronologic descoperit într-o săpătură arheologică la nivelul țării noastre, iar împreună cu depozitul Tărtăria I reprezintă o depunere cu caracter de unicat, atât prin natura sa, cât şi prin condiţiile de descoperire (anume faptul că până la descoperirea acestor două depozite astfel de depuneri - la nivelul perioadei $\mathrm{Ha}_{1}$ - nu mai fuseseră găsite în contextul unor cercetări arheologice, cu atât mai puţin două astfel de depuneri votive asociate unui singur context) ţinând cont de datele cunoscute până în prezent cu privire la civilizaţia Hallstatt-ului mijlociu în zona arcului carpatic şi a bazinului Dunării Mijlocii şi de Jos. Din componenţa sa fac parte circa 50 de arme şi piese de port de bronz şi fier, între care se distinge un „colan” compus din 7 torquesuri, o piesă cu caracter de unicat la nivelul actual de cunoaştere privitor la civilizaţia hallstattiană în bazinul carpatic al Dunării ${ }^{65}$, cel puţin în ceea ce privește starea sa de conservare. (PI. XL, L-LII)

CPL 114 - „mormânt” colectiv. Este vorba despre o descoperire funerară cu caracter aparte, conținând 6 schelete umane depuse - la acelaşi nivel - în poziţii şi cu orientări diverse, având în

\footnotetext{
(22 În chip evident sunt de notat toate convenţiile de definire şi utilizare a acestor repere cronologice generale.

${ }^{63}$ Pare 1999; Metzner-Nebelsick 2002

${ }^{64}$ Sunt cunoscute o serie de descoperiri comparabile în ceea ce priveşte structura depunerii în spaţiul actual al Serbiei şi Ungariei; pentru detalii, vezi Kemenczei 2005, Bratu 2009, 185-186.

${ }^{65}$ Vezi semnalările mai vechi cu privire la posibile piese similare din componenţa depozitului de la Bâlvănești, vezi Berciu 1942.
} 
inventar 12 piese de bronz şi fier, respectiv un al 7-lea craniu uman şi 3 căniţe tipice pentru stilul ceramic Basarabi. (PI. XXXVI-XXXVIII)

Fragmente de schelete umane au mai fost descoperite în următoarele contexte: CPL 004F (M8), CPL 004H (M9), CPL 004K (M10), CPL 004H (M11-M13), CPL 004R/CPL 186 (M14) şi CPL 242 (M15).

CPL 004/CPL 118 - şanţ de delimitare/apărare din zona sudică a aşezării hallstattiene, amenajat într-o viroagă naturală alimentată de izvoare subterane, un ,mediu umed" în care sau în a cărui vecinătate au fost făcute în perioada Hallstatt-ului mijlociu diverse depuneri (votive), anume fragmente de schelete umane (M8-M13), vase ceramice, piese de metal sau cele două depozite de piese de bronz şi fier. (Pl. XVI)

Așa cum am amintit, în inventarele complexelor cercetare au fost descoperite peste $150^{66}$ de vase întregi/întregibile provenind din inventarele complexelor cercetare şi nivelul de cultură hallstattian (unele vasele au fost descoperite ca atare din timpul săpăturii, iar acestora li se adãugă cele care au fost reîntregite în timpul procesului de triere şi restaurare). Acesta este unul dintre cele mai consistente și diversificate loturi de material ceramic provenit din cercetarea unui sit de tip Basarabi raportat la teritoriul actual al României. De asemenea, sunt de menționat cele peste 100 de piese de metal (bronz - peste 90 şi fier - peste 50) - provenind din inventarele complexelor cercetare, nivelul de cultură hallstattian şi passim, acesta fiind - foarte probabil - unul dintre cele mai semnificative loturi de piese din bronz şi fier (exceptând, desigur, cele două depozite de piese de bronz şi fier) provenit din cercetarea unui sit hallstattian din aria intracarpatică.

Acestor descoperiri datate în perioada mijlocie a primei epoci a fierului li se adaugă și:

- CPL 152 - tezaur monetar constituit din 238 de monede (denari republicani şi imitaţii) de argint, databil în secolele II-I a. Chr. ${ }^{67}$;

- CPL 151 - palisadă (incendiată) databilă - cel mai probabil - în perioada Evului Mediu timpuriu (secolele X-XII ?).

În continuare, ținând cont de amploarea descoperirilor arheologice efectuate în cuprinsul sitului Tărtăria-Podu Tărtăriei vest, cât și de stadiul preliminar al analizei post-săpătură a datelor şi materialelor arheologice, respectiv al restaurării loturilor de ceramică și piese din metal (atât cele din componența depozitelor Tărtăria I și Tărtăria II, dar și cele descoperite în inventarul unor complexe) sunt prezentate preliminar, pentru exemplificare, o serie de date cu privire la unele complexe arheologice.

CPL 002 (dimensiuni: 5,20 × 2,40 m; adâncime: 0,35 $\mathrm{m}^{68}$ ) (PI. XXIX, XLV)

Complexul s-a conturat, imediat după decaparea stratului vegetal, sub forma unei pete cu formă ovală, de culoare neagră, în una din secţiunile de diagnostic 2011 (S 511), limitele sale nefiind stabilite în acel moment. În campania 2012 secţiunea de sondaj a fost extinsă pentru cercetarea acestui complex. Complexul se afla într-o zonă în care terenul a fost arat mult mai adânc decât în restul sitului, astfel că s-a păstrat numai partea sa inferioară. Umplutura consta dintr-un sediment de culoare neagră-cenuşie, amestecat cu pigmenţi de chirpici şi cărbune, iar în partea de SE avea o consistenţă sfărâmicioasă. Inventarul complexului este compus din fragmente ceramice lucrate cu mâna, bucăţi mici de chirpici (cu şi fără amprente) şi câteva fragmente de oase de animal. Având în vedere dimensiunile mari ale gropii, putem presupune că aceasta reprezintă resturile unei locuinţe semiadâncite, deşi nu au mai fost surprinse alte elemente caracteristice (vatră, gropi de par etc.) unei asemenea structuri.

\footnotetext{
60 Această cifră include, atât vasele restaurate până în acest moment, dar și cele prelevate în timpul efectuării săpăturii și cele identificate preliminar în cursul procesului de triere a materialului ceramic. Este posibil ca la finalizarea procesului de restaurare această cifră să se modifice.

${ }^{67}$ Studiul numismatic al tezaurul monetar este în curs de realizare de către dr. Delia Moisil (MNIR - Cabinet numismatic). Dorim sã mulțumim — şi pe această calea — dr. Delia Moisil pentru analiza tezaurului, cât şi doamnei Marina Rogojină (MNIR - Sectiia Restaurare) pentru conservarea-restaurarea pieselor numismatice din cadrul acestui tezaurul monetar.

${ }^{68}$ Adâncimile complexelor sunt indicate de la nivelul de conturare al acestora.
} 
CPL 013 (dimensiuni: $1,30 \times 1,06 \mathrm{~m}$; adâncime: $0,20 \mathrm{~m} \mathrm{~S} / 0,80 \mathrm{~m} \mathrm{~N}$ ) (PI. XXX, XLVI)

Complexul a apărut la limita de $E$ a suprafeţei de cercetare $S_{\text {III }}$, intrând în profilul acesteia. După secţionarea sa a fost vizibil faptul că erau în fapt două gropi întretăiate. Cea din partea de S, de dimensiuni mai mici, este puţin adâncă şi aparent este „tăiată” de cea din partea de N. Groapa nordică era umplută cu pământ de culoare neagră cu urme de chirpici și cărbune, în timp ce cea sudică avea o umplutură de culoare brună-cenuşie cu urme de chirpici. După conturare în groapa sudică a fost descoperită o aglomerare de chirpici mărunţit, iar imediat lângă aceasta resturile unei piese din fier (fibulă ?). Groapa din partea de $\mathrm{N}$ se adâncește cu aprox. $0,60 \mathrm{~m}$ şi are formă relativ circulară în plan, pereţii săi fiind uşor cuptorîţi. Pe fundul acestei gropi au fost găsite mai multe vase sparte pe loc, inclusiv căni şi vase de provizii de dimensiuni medii. De asemenea, au mai fost găsite alte fragmente ceramice, chirpici şi câteva oase de animal. Poziţia vaselor în interiorul gropii sugerează că este posibil ca aceasta să fie o groapă de ofrandă şi nu neapărat una de provizii.

\section{CPL 021 (dimensiuni: $D_{\max }=7 \mathrm{~m}$; adâncime: $0,70 \mathrm{~m}$ ) (PI. XXXI, XLVII)}

Complexul s-a conturat imediat sub stratul vegetal, ca o pată de formă circulară, neregulată de mari dimensiuni. În umplutura de culoare neagră bine pigmentată cu chirpici şi cărbune, care era tot mai deschisă la culoare până spre galben în partea inferioară, au apărut mai multe vase parţial întregibile, precum și o aglomerare de chirpici mărunţit (probabil resturile unei vetre ?). În partea inferioară a gropii a fost găsit un craniu de animal mare (bovideu/cal ?). Din inventarul gropii mai fac parte o bilă de lut şi un obiect fragmentar din bronz. Tinând cont de caracteristicile şi inventarul său, acest complex reprezintă probabil resturile unei locuinţă semi-adâncite de mari dimensiuni.

CPL 025 (dimensiuni: $D_{\max }=5,60 \mathrm{~m}$; adâncime: $0,86 \mathrm{~m}$ ) (PI. XXXII)

Acest complex de mari dimensiuni a fost vizibil încă de la suprafatăa, astfel că la decaparea stratului de vegetal o parte din umplutura gropii a fost deranjată. Conturul gropii nu a putut fi stabilit precis de la început. După o serie de răzuieli succesive s-a dovedit a fi vorba de două gropi distincte, cea de mari dimensiuni continuând să fie identificată cu sigla CPL 025. În partea de SSV peretele gropii se cuptorea uşor. În partea de NE a apărut o zonă de arsură, cu bucăţi de lipitură (posibil resturi de vatră/perete prăbușit), însă nu foarte puternic arsă. Sub aceasta a fost observat un pat de bolovani de râu. Groapa pare să fi fost uşor înclinată pe direcţia NE-SV. În umplutura de culoare neagră cu urme de chirpici şi cărbune au apărut mai multe fragmente ceramice, oase de animal, pietre şi chirpici. Este foarte posibil ca acest complex să constituie resturile unei locuinţe semi-adâncite.

CPL 066 (dimensiuni: 3,80 × 3,60 m ; adâncime: 0,67 m) (Pl. XXXIII, XLIX/1-2)

Acest complex de mari dimensiuni a apărut la cca $-0,20 \mathrm{~m}$ de la nivelul actual de călcare, limitele sale fiind relativ neclare. După răzuieli succesive s-a putut contura o groapă de formă aproximativ circulară, iar în partea de SE o posibilă groapă de par (CPL 064). După golirea complexului au fost observate alte două gropi de par asemănătoare, în partea de $\mathrm{V}$ şi cea de $\mathrm{N}$. La circa $0,10 \mathrm{~m}$ de la nivelul de conturare a apărut o aglomerare de lipitură făţuită, posibil resturile unei podele de lut. Umplutura complexului consta dintr-un sediment negru cu urme de chirpici şi cărbune, foarte bine tasat. Inventarul complexului cuprinde fragmente ceramice lucrate cu mâna, inclusiv vase întregibile, resturi de chirpici (cu şi fără amprente) şi o bilă de lut. Tinând cont de caracteristicile şi inventarul său, acest complex este probabil o locuință semi-adâncită.

CPL 074 (dimensiuni: $D_{\max }=3,90 \mathrm{~m}$; adâncime: 0,60 m) (PI. XXXIV, XLVIII)

Complexul a fost observat sub forma unei pete de formă circulară, neregulată, fiind afectat în partea superioară de lucrări agricole moderne. Imediat după decaparea stratului de sol vegetal au început să apară aglomerări de ceramică şi chirpici, dispuse pe mai multe straturi. În partea de SE s-a conturat o groapă de par, iar în partea de NE a apărut un ,pat” de ceramică, în care puteau fi observate mai multe vase întregibile. Masa relativ compactă de fragmente ceramice se extindea spre $V$ şi partea centrală a gropii. În partea de SV a gropii a fost găsită o aglomerare de chirpici. După secţionarea şi golirea complexului, o altă groapă de par a apărut în partea nordică a acestuia. Umplutura gropii conţinea pământ negru, puternic pigmentat cu chirpici și cărbune, solul devenind tot mai gălbui către baza complexului. Din inventarul gropii provin, pe lângă ceramică lucrată cu mâna şi chirpici, câteva obiecte fragmentare din bronz şi fier, oase de animale, jetoane de lut, o bilă şi o mărgea din lut. Este foarte posibil ca acest complex să reprezinte resturile unei locuințe semi-adâncite. 


\section{$\mathrm{XLIX/3)}$}

CPL 110 - CPL 113 (dimensiuni CPL 110: 4,50 × 3,30 m; adâncime: 0,65 m) (PI. XXXV,

CPL 110 era unul de mari dimensiuni; a fost sectionat ,în cruce" pentru a stabili cât mai exact relația cu gropile (de par ?) observate în imediata sa vecinătate, anume în zona de NE (CPL 111), de SE (CPL 112) și către SSV (CPL 113).

În urma secționării s-a observat că cea mai mare cantitate de material ceramic (inclusiv două vase întregibile) și osteologic se concentra în cadranul de NV. S-a observat că de jur-împrejurul complexului exista o treaptă, groapa având formă oval-alungită și pereți tronconici. Umplutura consta din pământ negru amestecat cu pigmenți de chirpici și cărbune în care au apărut fragmente ceramice, chirpici cu și fără amprente, lipitură de vatră, o cute și oase de animal (răspândite). Tinând cont de caracteristicile şi inventarul său, acest complex este probabil o locuinţă semi-adâncită de mari dimensiuni.

CPL 111 a apărut la 0,35 m NE de CPL 1 10, sub forma unei pete (cu diametru de 0,65 m), de culoare brună-cenușie, foarte slab pigmentată cu chirpici și fără material arheologic. Pereții sunt tronconici, fundul convex; adâncimea de la conturare este de $-0,15 \mathrm{~m}$.

CPL 112 a fost observat la 0,65 m SE de CPL 110, sub forma unei pete (cu diametru de 0,60 m), de culoare brună-cenușie. S-a observat aceeaşi umplutură ca şi în cazul CPL 111, fără material arheologic. Pereții sunt tronconici; adâncimea de la conturare este de $-0,15 \mathrm{~m}$.

CPL 113 era direct săpat în ,treapta” observată în interiorul CPL 110. S-a conturat ca o groapă de formă ovală, cu dimensiuni de $0,85 \times 0,70 \mathrm{~m}$. Ca şi în cazul CPL 111 și CPL 112 în umplutura sa nu exista material arheologic. Pereții sunt tronconici, fundul convex; adâncimea de la conturare este de $-0,30 \mathrm{~m}$.

CPL $114^{69}$ (dimensiuni: $4 \times 3,50 \mathrm{~m}$ ) (PI. XXXVI-XXXVIII)

Complex de mari dimensiuni, cu formă aproximativ circulară la nivelul de conturare. După începerea secționării, în partea de $\mathrm{N}$ a complexului au apărut două obiecte din bronz și mai multe oase friabile. Ulterior s-a constatat că aceste oase, situate în partea de NV a gropii, sunt umane. De asemenea, în timpul cercetării complexului, în partea de NE au apărut resturi osteologice care aparțineau unui al doilea individ. Treptat, pe măsură ce săparea complexului a continuat, în aceeaşi jumătate nordică a gropii au apărut în total resturile a 6 defuncți (de vârste diferite ${ }^{70}$ ). Adâncimea nivelului la care fuseseră depuși cei 6 indivizi era de $-0,60 \mathrm{~m}$ de la nivelul de conturare. Defuncții au fost marcați cu sigle de la M1 la M6 după cum urmează:

- M1 - așezat pe o parte, ușor ,întors" din bazin, craniul orientat spre E;

- M2 - dispus central în colțul de NV al complexului, între M1 și M3; așezat pe partea stângă, cu membrele inferioare îndoite până la bazin, orientat SE (craniu)-NV (membre inferioare);

- M3 - aceeași poziție ca M2, situat în partea dorsală a acestuia, având membrele inferioare parțial suprapuse peste cele ale lui M2;

- M4 - situat în zona centrală a complexului, în poziție chircită, cu fața orientată spre E;

- M5 - așezat pe partea dreaptă, cu picioarele îndoite până la bazin, cu fața orientată spre $\mathrm{SE}$

- M6 - situat imediat la S de M5, „lipit” de acesta, aşezat în decubit dorsal, cu craniul îndreptat spre M5.

Scheletele aveau o stare precară de conservare, fiind extrem de prost păstrate in situ; în unele cazuri au mai putut fi observate numai amprentele oaselor.

În jumătatea sudică a complexului, pe același nivel la care în jumătatea nordică fuseseră observate cele 6 schelete, nu au mai apărut alte resturi osteologice umane. După demontarea celor 6 schelete, s-a putut observa că acestea fuseseră depuse pe un strat subțire, uniform de pământ galben.

\footnotetext{
${ }^{69}$ Toate resturile osteologice umane descoperite în cadrul sitului sunt în prezent analizate de către domnul Gabriel Vasile, care urmează să elaboreze studiul antropologic. Ii mulțumim și pe această cale pentru acest demers.

${ }^{70}$ Datele prezentate au caracter preliminar, fiind în curs de pregătire un articol având ca temă această descoperire funerară cu caracter aparte. Din observațiile efectuate cu ocazia săpării complexului, cele 6 schelete par să fie: doi indivizi adulți (situatii în partea de ENE a gropii, notați cu siglele M5 și M6), un copil (situat aproximativ în centrul gropii, notat cu sigla M4), respectiv trei adolescenți (în partea de VNV a gropii, notați cu siglele Ml la M3).
} 
După efectuarea unei noi răzuieli, în partea de SE a complexului s-a conturat o altă groapă de formă ovală, care se adâncea cu aproximativ $0,40 \mathrm{~m}$ față de nivelul pe care fuseseră depuși cei 6 indivizi. În această groapă (notată cu sigla CPL 114B) au apărut un craniu uman, o cană (depusă în poziție verticală imediat lângă craniu) şi fragmente ceramice.

Aproximativ în centrul complexului CPL 114, s-a conturat o altă pată de culoare închisă, având formă circulară; aceasta avea diametrul de $0,40 \mathrm{~m}$ și se adâncea la $-0,50 \mathrm{~m}$ față de nivelul pe care au fost depuși cei 6 indivizi.

La prelevarea scheletelor au apărut 12 mici piese din bronz şi fier, care constituie - foarte probabil - inventarul funerar al celor 6 defuncți.

CPL 147 (dimensiuni: 1,80 × 1,20 m; adâncime: 0,30 m) (Pl. XLI, LV)

Complexul s-a conturat imediat după îndepărtarea stratului de sol vegetal, sub forma unei pete de dimensiuni medii şi formă neregulată. Umplutura gropii este constituită dintr-un sediment negru amestecat cu chirpici și cărbune mai ales în zona vaselor. În partea inferioară a gropii se aflau mai multe vase ceramice fragmentare, sparte pe loc. Din inventarul gropii mai provin alte fragmente ceramice, o bucată mare de râş̧iţă şi o lamă de cuţit din fier. Poziţia vaselor în interiorul gropii sugerează că aceasta ar putea fi o groapă de ofrandă.

CPL 183 (dimensiuni: $1,90 \times 1,70$ m; adâncime: 0,70 m) (PI. XLII, LVI)

Această groapă a fost identificată la demontarea martorului stratigrafic median din partea vestică a suprafeței de cercetare $S_{111}$. Umplutura gropii constă dintr-un sediment negru cu urme de chirpici şi cărbune, iar la baza complexului a fost observat un strat de pietriş. La aproximativ $0,50 \mathrm{~m}$ de la nivelul de conturare a fost observat un grup compact de vase sparte pe loc, respectiv patru căni, două vase pântecoase și o căniţă. Dispunerea vaselor şi modul lor de conservare par să indice faptul că acestea au fost depuse (intenţionat). De la nivelul vaselor sparte pe loc pereţii gropii se cuptoreau către baza complexului. Printre vase au mai fost descoperiţi câţ̧iva galeţi de râu, dar şi oase de animal (arse şi nearse) şi obiecte din bronz. Dispunerea vaselor în interiorul gropii pare să indice că aceasta ar fi putut fi o groapă de ofrandă.

CPL 190 (dimensiuni: 1,25 × 1,15 m; adâncime: 0,20 m) (PI. XLIII, LVII)

Imediat după decaparea stratului vegetal au devenit vizibile contururile mai multor vase, depuse într-o groapă de formă aproximativ circulară. Partea superioară a gropii a fost puternic afectată de lucrări agricole contemporane. Umplutura gropii consta într-un sediment negru cu pigment de chirpici, având consistenţă lutoasă, foarte bine tasată. După curăţare, au fost identificate 6 vase întregibile, aşezate unul lângă altul, printre acestea fiind şi un platou deosebit de friabil, aproape imposibil de prelevat. Vasele erau aşezate direct pe sol, iar în afara acestora nu a mai fost găsit alt material arheologic. Poziţia vaselor în interiorul gropii sugerează că este posibil ca aceasta să fie o groapă de ofrandă.

CPL 237 (dimensiuni: 1,20 × 1 m; adâncime: 0,70/0,80 m) (PI. XLIV, LVIII)

Complexul a fost conturat imediat după decaparea stratului vegetal, inițial sub forma unei pete de formă ovală (dimensiuni: $1 \times 0,60 \mathrm{~m}$ ), de culoare brună-oranj, în centrul acesteia fiind observate resturi de lipitură de vatră (?), chirpici și o serie de fragmente ceramice (CPL 237 B). La secționare, la $-0,20$ m față de resturile de vatră, a fost observată o a doua groapă, de formă relativ circulară, situată aproximativ la sud de CPL 237B. Aceasta era suprapusă de resturile de vatră numai în capătul său nordic. În inventarul complexului se aflau mai multe vase sparte pe loc, așezate unele peste altele. Umplutura gropii constă dintr-un sediment negru, pigmentat cu urme de chirpici și cărbune. Pereții gropii (cu vase sparte in situ) erau drepți. 
O imagine de ansamblu asupra dimensiunii și complexității descoperirilor arheologice realizate în cadrul sitului Tărtăria-Podu Tărtăriei vest este prezentată în tabelul-anexă. Acesta conține informații preliminare despre asocierea principalelor categorii de material (vase întregi/întregibile, fragmente consistente de chirpici, schelete și fragmente de schelete umane, oase de animal - inclusiv prelucrate, piese din metal și piatră prelucrată), respectiv raportul dintre ceramica atipică și cea caracteristică stilului Basarabi.

Datele statistice obținute din analiza preliminară post-săpătură indică următoarele:

- au fost descoperite vase întregi/întregibile în 81 de complexe, respectiv 31,39\% din total;

- a fost descoperită ceramică tipică stilului Basarabi în 202 de complexe, respectiv 78,29\% din total;

- a fost descoperită în asociere ceramică atipică și tipică stilului Basarabi în 200 de complexe, respectiv $77,51 \%$ din total;

- au fost descoperite piese de bronz (întregi, fragmentare sau urme) în 44 de complexe (inclusiv depozitele Tărtăria I și Tărtăria II), respectiv $17,05 \%$ din total;

- au fost descoperite piese de fier (întregi, fragmentare sau urme) în 25 de complexe (inclusiv depozitele Tărtăria I și Tărtăria II), respectiv $9,68 \%$ din total;

- au fost descoperite piese din metal (bronz și fier) în 59 de complexe (inclusiv depozitele Tărtăria I și Tărtăria II), respectiv $22,86 \%$ din total;

- au fost descoperite resturi osteologice animale în 49 de complexe, respectiv $18,99 \%$ din total;

- au fost descoperite oase animale cu urme de prelucrare numai în cazul a 3 complexe, respectiv $1,16 \%$ din total;

- a fost descoperit material litic (piatră prelucrată) în 26 de complexe, respectiv $10,06 \%$ din total;

- au fost descoperite fragmente de chirpici și lutuială în 98 de complexe, respectiv 37,98\%.

\section{CONCLUZII}

Toate descoperirile efectuate în cadrul sitului arheologic Tărtăria-Podu Tărtăriei vest vin să nuanţeze - pe de o parte - concluziile studiului de diagnostic arheologic şi reconfirmă în mod evident un fapt de altfel bine cunoscut anterior - printr-o serie de semnalări şi descoperiri întâmplătoare, dar şi prin cercetări mai vechi, de mai mică sau mai mare amploare -, anume potenţialul arheologic semnificativ privind perioada Hallstatt-ului mijlociu existent de-a lungul văii mijlocii a Mureşului (zona Alba Iulia-Orăștie). (PI. IV)

Astfel, cercetarea arheologică preventivă a părţii sudice a sitului Tărtăria-Podu Tărtăriei vest a furnizat date şi descoperiri arheologice semnificative. Construcţia viitoarei autostrăzi a afectat numai parţial acest sit şi, în aceste condiţii, a creat premisele pentru cercetarea în suprafaţă a părţii sudice a unei importante zone de habitat preistoric, databil în perioada mijlocie a primei epoci a fierului (mai exact aşa-numita perioadă a culturii Basarabi). De asemenea, în limita estică a acestuia a fost documentată o secvenţă ocupaţională încadrabilă în epoca medievală timpurie (?), respectiv un sistem de fortificaţie (val cu palisadă, incendiată). Rămâne un deziderat de perspectivă clarificarea motivului pentru care a fost construită această fortificaţie, având în vedere că nu au fost descoperite - pentru moment - alte structuri (de locuire ?) databile în aceeaşi epocă. Este mai mult decât evident faptul că situl continuă spre nord, către DN7 şi valea Mureşului, astfel că trebuic avută în vedere parcurgerea cât mai curând posibil - procedurii de clasare a acestui perimetru pentru instituirea unui regim (minimal) de proteç̧ie juridică şi iniţierea unui program de cercetare arheologică cu caracter programat în această zonă. 
În ceea ce priveşte aşezarea hallstattiană, datele stratigrafice şi materialul arheologic descoperit în campania 2012 oferă argumente foarte solide pentru a considera situl Tărtăria-Podu Tărtäriei vest, respectiv situl arheologic situat pe terasa superioară (stângă) a Mureşului, la S de DN7 și la V actualul traseu al DC705E, drept unul deosebit de important pentru studierea perioadei Hallstatt-ului mijlociu (aşa-numita perioadă a stilului ceramic Basarabi) în aria intracarpatică şi în bazinul carpatic al Dunării.

Depozitele Tărtăria I și Tărtăria II reprezintă depuneri cu caracter de unicat, atât prin natura lor (reunind deopotrivă elemente de prestigiu social și meșteşug), cât şi prin contextul cert de descoperire, raportat la civilizaţia Hallstatt-ului mijlociu în zona arcului carpatic şi a bazinului Dunării mijlocii şi de jos. Analiza aprofundată a acestor descoperiri, cu caracter excepțional pentru preistoria României și a zonei Europei Centrale şi de Sud-Est, poate aduce noi repere pentru cunoaşterea perioadei Hallstatt-ului mijlociu în aria intracarpatică şi în bazinul carpatic al Dunării ${ }^{71}$. Studiul în detaliu, axat pe elemente de tipologie, chorologie și analiză elementală, al celor două depozite de bronzuri va determina o mai bună înțelegere a modelelor de difuziune a diverselor piese de metal asociate „cercului de forme traco-cimmerian", 72 , prin analizarea relaţiilor „culturale” (de schimb) ale spaţiului carpatic cu zona nord-pontică, cea vest-balcanică şi cea est-alpină, în primele secole ale mileniului I a. Chr., într-un moment de referință pentru pre- și protoistoria spațiului central și sud-est european. Depozitele de bronzuri datate la nivelul secolelor IX-VII a. Chr. marchează ultima etapă a unui fenomen cultural-istoric de primă importanță al epocii metalelor, anume depunerea votivă $\check{a ̆}^{73}$ a pieselor din metal. Analiza compoziției depozitelor de bronzuri, cu precădere a celor de la finalul epocii metalelor, altfel spus din zorii protoistoriei europene, în special prin depășirea abordărilor strict cronologice și aprofundarea modelelor de răspândire a variilor categorii de artefacte asociate, oferă numeroase posibilități pentru valorificarea acestei categorii de izvoare arheologice. Într-o atare perspectivă, depozitele de bronzuri trebuie înțelese drept vestigii materiale ale unor practici rituale, având posibile conotații de ordin religios, caracteristice unor spații relativ vaste la nivel european. Analiza structurală a acestor categorii de ofrande preistorice și studierea, cu cât mai mare acuratețe, a contextelor lor de depunere sunt direcții noi de cercetare în domeniu, care deschid noi posibilități pentru îț̦elegerea unor manifestări spirituale din timpuri străvechi.

De remarcat că structura depunerii este deosebit de complexă în cazul depozitelor Tărtăria I și II, acestea reunind arme, unelte, piese de port și de harnașament ce pot fi asociate pe de o parte spațiului vest-balcanic, dar și celui nord-pontic (PI. LIII). Astfel, printre obiectele de sorginte răsăriteană se numără o serie de piese de harnașament (zăbală, faleră cu ,zornăitoare”, butoni ajurați) și de port (pandantiv), iar în cazul celor de origine meridională o serie de piese de port (fibule ochelari, fibulă cu nodozități, torquesuri, ace de păr). Caracterul de „complex închis” al ambelor depozite oferă premisele certe ale unei documentări extrem de riguroase a structurării acestor depuneri, cât și ale unor cercetări pluridisciplinare privind analiza elementală a pieselor componente. Nu în ultimul rând se adaugă resturi de natură organică, prelevate cu ocazia descoperirii, investigarea acestora aducând noi elemente. Deopotrivă, o asemenea abordare în detaliu va permite o mai bună corelare a sistemelor cronologice utilizate pentru prima jumătate a mileniului I a. Chr. în zona Europei Centrale și de SudEst, inclusiv ținând cont de cele mai recente contribuții în domeniu datorate Carolei MetznerNebelsick sau lui Christopher Pare; în acest mod pot fi înțelese mai bine o serie de manifestări culturale din pre- și protoistoria spațiului european.

În egală măsură, o altă direcție dcosebit de importantă a analizei post-săpătură vizează studiul ceramicii descoperite în cuprinsul acestui sit. Prin dimensiunea, complexitatea și diversitatea sa, acest lot ceramic creează premisele aprofundării și reconsiderării opiniilor cu privire la stilul ceramic Basarabi. De remarcat că - pentru moment - din repertoriul de forme specific stilului amintit, lipsesc în cazul sitului Tărtăria-Podu Tărtăriei vest două forme caracteristice, respectiv vasul de tip „fructieră” și strachina cu margine lată, răsfrântă spre exterior. De asemenea, în ceea ce privește

\footnotetext{
${ }^{71}$ Vulpe 1986; László 2001; Petrescu-Dâmbovița 2001; Vulpe 2001

${ }^{72}$ Pentru aşa-numitele bronzuri cimmeriene sau de tip „,bird cage”, vezi Bouzek 1971 (cu bibliografia mai veche); pentru considerații mai recente asupra noțiunii de „orizont traco-cimmerian”, vezi Sauter 2000 (publicație disponibilă on-line la adresa http://www.kimmerier.de/kap02100.htm, accesată în data de 16.05.2013); Metzner-Nebelsick 2002.

${ }^{73}$ Hansen 1992
} 
motivistica acestui stil ceramic, analiza preliminară post-săpătură tinde să reconfirme faptul că descoperirile de tip Basarabi din zona Tărtăria par să indice existența materialului caracteristic primelor două faze ${ }^{74}$.

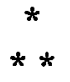

În încheiere, trebuie amintit faptul că a fost propusă, la începutul anului 2013, întreprinderea - în regim de urgenţă - tuturor demersurilor ştiinţifice şi legale necesare pentru clasarea zonei situate la $\mathrm{N}$ de traseul autostrăzii ca ,monument istoric de categorie A", respectiv perimetrul delimitat la V de valea Cioarei, la N de traseul DN7 și calea ferată Arad-Alba Iulia, la E de Valea Tărtăriei și actualul traseu al DC705 E și la S de traseul autostrăzii Al.

Notă: Mulțumiri domnului Marius Amarie pentru fotografiile pieselor din componența depozitelor Tărtăria I şi Tărtăria II, utilizate la realizarea planşelor L-LII.

BIBLIOGRAFIE

Legea nr. 258/2006

LMI 2010

OG nr. 43/2000

OMCC nr. 2392/2004

OMCC nr. 2518/2007

OMCPN nr. 2613/2011

Legea nr. 2001-44/2001 (Franța)

PPG 16

(Marea Britanie)

$* * * 1982$

Aldea, Ciugudean 1987
Lege pentru modificarea si completarea Ordonanfei Guvernului nr. 43/2000 privind protectia patrimoniului arheologic si declararea unor situri arheologice ca zone de interes nafional, Monitorul Oficial nr. 603 în data de 12 iulie 2006 Lista Monumentelor Istorice, Monitorul Oficial, partea I, nr. 670 din 1 octombrie 2010

Ordonanta Guvernului nr. 43/2000 privind protecfia patrimoniului arheologic şi declararea unor situri arheologice ca zone de interes nafional (nepublicată în Monitorul Oficial)

Ordinul Ministrului Culturii si Cultelor nr. 2392/06.09.2004 privind instituirea Standardelor şi Procedurilor arheologice, disponibil la adresa http://www.cimec.ro/Arheologie/Legislatie/OMC_Standarde.pdf http://www.cimec.ro/Arheologie/standarde2.htm (nepublicat în Monitorul Oficial) Ordinul Ministrului Culturii si Cultelor nr. 2518/2007 pentru aprobarea Metodologiei de aplicare a procedurii de descărcare de sarcină arheologică, disponibil la adresa http://www.cultura.ro/Files/GenericFiles/OMCC-2518-2007DescarcareAarcinaArheologica.pdf (nepublicat în Monitorul Oficial)

Ordinul Ministrului Culturii şi Patrimoniului National nr. 2613/2011 privind aprobarea Procedurii de emitere a certificatului de descărcare de sarcina arheologică în cazul proiectelor de infrastructură de transport de interes national, Monitorul Oficial nr. 93/6 februarie 2011

Loi n²001-44 du 17 janvier 2001 relative à l'archéologie préventive, version consolidée au 24 février 2004, http://www.legifrance.gouv.fr

***, Planning Policy Guidance 16: Archaeology and planning, 1990, http://www.communities.gov.uk/documents/planningandbuilding/pdf/156777

Enciclopedia geografică a României, Editura Ştiinţifică şi Enciclopedică, Bucureşti, 1982

Al. I. Aldea, H. Ciugudean, Depozitul hallstattian de la Vinţu de Jos III, Apulum 24,1987 , p. $81-79$

\footnotetext{
${ }^{74}$ Vezi în acest sens opiniile formulate anterior de către Gumă 1993, 203, 233; Ciugudean 1997, 148, 158-159, fig. 3, 31/ 12; Ursuțiu 2002, 74-75.
} 
Aldea, Ciugudean 1995

Berciu 1942

Bratu 2009

Bouzek 1971

Ciugudean 1997

Damian et alii 2012

Drewett 2011

László 2001

Geografia

Ghenescu, Sana,

Ştefu 2000

Grant et alii 2005 (2008)

Green 2002

Hansen 1992

Horedt 1947-1949

Kemenczei 2005

Martian 1920

Metzner-Nebelsick 2002

Metzner-Nebelsick 2005

Neumann, Sanford 2001

Pare 1999

Petrescu-Dâmbovița 1977

Petrescu-Dâmboviţa 2001

Popa 2011

Popa, Berciu 1964

Popa, Berciu 1965

Renfrew, Bahn 2008
Al. I. Aldea, H. Ciugudean, Der dritte hallstattzeitliche Depotfund von Vinţu de Jos, in T. Soroceanu (Hrsg.), Bronzefunde aus Rumänien, Berlin, 1995, p. $213-$ 224

I. Berciu, Depozitul de bronz de la Orăştie, Apulum 1, 1939-1942 (1942), p. 8097

Olimpia Bratu, Depuneri de bronzuri între Dunărea Mijlocie şi Nistru în secolele XIII-VII a. Chr., Bucureşti, 2009

J. Bouzek, Openwork 'bird-cage' bronzes, în J. Boardmann, M.A. Brown, T.G.E. Powell (eds.), The European Community in Later Prehistory. Studies in honour of C.F.C. Hawkes, Routledge \& Kegan Paul, London, 1971, p. 77-104

H. Ciugudean, Cercetări privind epoca bronzului şi prima vârstă a fierului in Transilvania, BMA VII, Alba Iulia, 1997

P. Damian, I. Bocan, E. Dumitraşcu, D. Ene, S. Ene, M. Streinu, Autostrada Orăştie-Sibiu, Lot 1 (Orăştie-Sebeş), km 00+000-24+110, jud. Hunedoara, Alba, CCA 2012, nr. 156, p. 280

P. Drewett, Field Archaeology. An Introduction, $2^{\text {nd }}$ edition, Routledge, London, 2011

A. László, Prima epocã a fierului, în vol. Istoria Românilor. Moştenirea timpurilor îndepărtate, vol. 1, Editura Enciclopedică, București, 2001, p. 294-326

***, Geografia României, vol. I, Geografia fizică, București, 1983; Geografia României, vol. III, Carpaţii Româneşti şi Depresiunea Transilvaniei, București, 1987

O. Ghenescu, D.V. Sana, V. Ştefu, Cercetări arheologice de suprafaţă în sectorul Vinţu de Jos - Tărtăria (jud. Alba), în BCSS, 6, 2000, p. 69-85

J. Grant, S. Gorin, N. Fleming, The archaeology coursebook: an introduction to study skills, topics and methods, Routledge, 2005 (re-editare 2008)

K. Greene, Archaeology: an introduction, Routledge, 2002

S. Hansen, Depozitele ca ofrandã: o contribuţie la interpretarea descoperirilor de depozite din perioada timpurie a UFZ, $S C I V A, 43,1992,4$, p. 371-392

K. Horedt, Săpăturile privitoare la epoca neo- și eneolitică, Apulum, 3, 1949, p. 44-69

T. Kemenczei, Funde ostkarpatenländischen Typs im Karpatenbecken, PBF, XX, 10, Stuttgart, 2005

I. Marțian, Repertoriu arheologic pentru Ardeal, Bistriţa, 1920

Carola Metzner-Nebelsick, Der ,.Thrako-Kimmerische” Formenkreis aus der Urnenfelder- und Hallstattzeit im südöstlichen Pannonien, 1-2, Vorgeschichtliche Forschungen 23, Verlag Marie Leidorf Gmbh, Rahden/Westf., 2002

Carola Metzner-Nebelsick, Despre importanța cronologică şi cultural-istorică a depozitelor din România în epoca târzie a bronzului şi în epoca timpurie a fierului, în T. Soroceanu (Hrsg./ed.), Bronzefunde aus Rumänien II./Descoperiri de bronzuri din România II, Editura Accent, Bistrița/Cluj-Napoca, 317-342

Th. W. Neumann, R. M. Sanford, Practicing Archaeology. A Training Manual for Cultural Resources Archaeology, 2001

C.F. Pare, Beiträge zum Übergang von der Bronze- zur Eisenzeit in Mitteleuropa.

Teil I. Grundzüge der Chronologie im östlichen Mitteleuropa (11. - 8. Jahrhundert v. Chr.), în Jahrbuch des Römisch-Germanischen Zentralmuseum Mainz, 45, 1998 (1999), p. 293-433

M. Petrescu-Dâmboviţa, Depozitele de bronzuri din România, Bucureşti, 1977

M. Petrescu-Dâmboviţa, Înflorirea și declinul metalurgiei bronzului în prima epocă a fierului, în vol. Istoria Românilor. Moştenirea timpurilor indepărtate, vol. 1, Bucureşti, 2001, p. 339-347

C.I. Popa, Valea Cuginului din preistorie până în zorii epocii moderne. Monumenta archaeologica et historica, Cluj-Napoca, 2011

A. Popa, I. Berciu, Contributions a l'étude des objectes hallstattiens, Dacia N.S., 8, 1964, p. $87-100$

A. Popa, I. Berciu, Un depozit de obiecte hallstattiene de la Vinţul de Jos, Apulum, 5, 1965, p. 51-70

C. Renfrew, P. Bahn, Archaeology: Theories, Methods and Practice, $5^{\text {th }}$ edition, Thames \& Hudson, Londra, 2008 
RepAB 1995

Roskams 2001

Rusu 1963

Sauter 2000

Soroceanu 1982

Tasić 1972

Tasić 2004

Tufescu 1966

Ursuţiu 2002

Vulpe 1986

Vulpe 2001

Vulpe 2001a

Westcott, Brandon 2000
Repertoriul arheologic al judefului Alba, V. Moga, H. Ciugudean (red.), BMA II, Alba Iulia, 1995

S. Roskams, Excavation, Cambridge University Press, 2001

M. Rusu, Die Verbreitung die Bronzehorte in Transilvannien vom Ende Bronzezeit in die mitllere Hallstattzeit, Dacia N.S., 7, 1963, p. 177-210

H. Sauter, Studien zur Kimmerierproblem, Band 72 der Saarbrücker Beiträge zur Altertumskunde (publicație on-line disponibilă la adresa http://www.kimmerier.de/kap02100.htm, accesată în data de 16.05.2013)

T. Soroceanu, Hortfunde und befestigte Anlagen in Transilvaniei, în $B$. Chropovski, J. Herrmann (Hrsg.), Beiträge zur bronzezeitliche Burgenbau in Mitteleuropa, Berlin-Nitra, 1982, p. 363-376

N. Tasić, An Early Iron Age Collective Tomb at Gomolava, Archaeologia Iugoslavica, XIII, 1972, p. 27-37

N. Tasić, Historical Picture of the Development of the Early Iron Age in the Serbian Danube Basin, Balcanica, XXXV, 2004, p. 5-22

V. Tufescu, Subcarpatii şi depresiunile marginale ale Transilvaniei, București, 1966

A. Ursuţiu, Etapa mijlocie a primei vârste a fierului in Transilvania (Cercetările de la Bernadea, com. Bahnea, jud. Mures), IEC V, Cluj-Napoca, 2002

A. Vulpe, Zur Entstehung der geto-dakischen Zivilisation. Die Basarabi-Kultur, Dacia N.S. 30, 1-2, 1986, p. 49-91

A. Vulpe, Prima epocã a fierului. Perioada mijlocie (cca 850/800 - 650 a. Chr.), în vol. Istoria Românilor. Mosstenirea timpurilor indepărtate, vol. 1, Editura Enciclopedică, Bucureşti, 2001, p. 327-339

A. Vulpe, Structuri sociale şi credinţe religioase în epoca bronzului şi în prima epocă a fierului, în vol. Istoria Românilor. Moştenirea timpurilor indepărtate, vol. 1, București, 2001, p. 353-377

Konnie L. Westcott, J. Brandon (eds.), Practical Applications of GIS for Archaeologists. A Predictive Modeling Toolkit, Taylor Francis, London, 2000

\section{LIST OF ILLUSTRATION}

Pl. I. The investigated area mapped on various cartographic sources

PI. II. Location of the investigated area on ortophotomaps and satellite images; a. Ortophotomap of 2005 overlapped by the initial delimitation of the site; b. Location of the investigated area on ortophotomaps and satellite images $(2005,2012)$

PI. III. Basarabi type discoveries nearby the site Tărtãria-Podu Tărtăriei vest

Pl. IV. Basarabi type discoveries on Orăștie-Alba Iulia zone

PI. V. General overviews of the site's area before the beginning of the excavation

Pl. VI. General overviews during the preventive archaeological excavations

PI. VII. Aerial images of the site at the end of the preventive archaeological excavations (2012)

Pl. VIII. Trial trenches during the field archaeological evaluation

Pl. IX. Layout of the excavation units

PI. X. Detail on the location of the cross-section along CPL 004/CPL 118

PI. XI. Layout of the archaeological complexes

Pl. XII. Layout of the archaeological complexes (detail on the SW zone)

PI. XIII. Layout of the archaeological complexes (detail on the NE zone)

PI. XIV. Layout of the archaeological complexes (detail on the relocation zone of DC705E)

PI. XV. Distribution of special archaeological material

PI. XVI. Distribution of special archaeological material (detail on the SW zone)

PI. XVII. Distribution of special archaeological material (detail on the NE zone)

PI. XVIII. Distribution of special archaeological material (detail on the relocation zone of DC705E)

PI. XIX. Main N cross-section profiles. Photos: 1. S VI; 2. S III (two research stages); drawings: 1. S VI; 2. S III

Pl. XX. S 008, CPL 004/118, main W cross-section profile (photo \& drawing)

PI. XXI. S 019, N cross-section profile (photo \& drawing)

PI. XXII. S 019, S cross-section profile (photo \& drawing)

Pl. XXIII. S 027 (relocation zone of DC 705E), main N cross-section profile (drawing \& photo)

PI. XXIV. CPL 004, S003, W cross-section profile (photos \& drawing) 
Pl. XXV. CPL 118B, W cross-section profile (photo \& drawing)

PI. XXVI. S V, CPL 004M/118 and CPL 122 (hoard Tărtăria II), E cross-section profile (photo \& drawing)

Pl. XXVII. S IV, CPL 004G/1 18, W cross-section profile (photo \& drawing)

PI. XXVIII. S VIII, CPL 118D, E cross-section profile (photo \& drawing)

Pl. XXIX. CPL 002: 1. Ground plan and profile; 2-5. Images during the excavation of the complex

PI. XXX. CPL 013: 1. Ground plan and profile; 2-8. Images during the excavation of the complex

PI. XXXI. CPL 021: 1. Ground plan and profile; 2-6. Images during the excavation of the complex

Pl. XXXII. CPL 025: 1. Ground plan and profile; 2-7. Images during the excavation of the complex

PI. XXXIII. CPL 066: 1 . Ground plan and profile; $2-6$. Images during the excavation of the complex

Pl. XXXIV. CPL 074: 1. Ground plan and profile; 2-6. Images during the excavation of the complex

PI. XXXV. CPL 110, 111, 112,113: 1. Ground plan and profile; 2-7. Images during the excavation of the complex

PI. XXXVI. CPL 114 and CPL 114B (collective ,grave”): Ground plan and profile; 2-4. Images during the excavation of the complex

Pl. XXXVII. 1. CPL 114 (collective ,grave”) - overview; 2. M 1 (right up), M 2 (centre), M3 (left down); 3. M4; 4. M5 (left), M6 (right)

PI. XXXVIII. CPL 114 B: 1-5. Images during the excavation of the complex

PI. XXXIX. CPL 116 (hoard Tărtăria I): 1-4. Images during the excavation of the complex

PI. XL. CPL 122 (hoard Tărtăria II): 1-4. Images during the excavation of the complex

PI. XLI. CPL 147: 1. Ground plan and profile; 2-8. Images during the excavation of the complex

Pl. XLII. CPL 183: 1. Ground plan and profile; 2-6. Images during the excavation of the complex

PI. XLIII. CPL 190: 1. Ground plan and profile; 2-7. Images during the excavation of the complex

PI. XLIV. CPL 237: 1. Ground plan and profile; 2-6. Images during the excavation of the complex

PI. XLV. CPL 002: Ceramic material (selection)

PI. XLVI. CPL 013: Restored pottery

PI. XLVII. CPL 021: Pottery on restoration

PI. XLVIII. CPL 074: Pottery on restoration

PI. XLIX. 1-2. CPL 066, 3. CPL 110: Pottery on restoration

PI. L. Adomment objects of hoards Tărtăria I and Tărtăria II: 1. Torques and pendant of hoard Tărtăria I; 2. Bracelets of hoard Tărtăria I; 3. Brooches of hoards Tărtăria I and Tărtăria II (photo Marius Amarie)

PI. LI. Adornment and hamess objects of hoards Tărtăria I and Tărtăria II: 1. Curl rings (hair pins) of hoard Tărtăria I; 2. Phalerae of hoards Tărtăria I and Tărtăria II; 3. Phalerae, tutuli and buttons of hoards Tărtăria I and Tărtăria II (photo Marius Amarie)

PI. LII. Iron weapons and tools of hoards Tărtăria I and Tărtăria II: 1. Socketed axes of hoards Tărtăria I and Tărtăria II; 2. Spears of hoard Tărtăria II; 3. Short swords, flat winged ax and chisel of hoards Tărtăria I and Tărtăria II (photo Marius Amarie)

PI. LIII. „Structure” of the deposition on hoards Tărtăria I and Tărtăria II

PI. LIV. Hoards of $\mathrm{Ha} \mathrm{B}_{3}-\mathrm{C}$ period discovered in Romania

Pl. LV. CPL 147: Pottery on restoration

PI. LVI. CPL 183: Pottery on restoration

PI. LVII. CPL 190: Pottery on restoration

PI. LVIII. CPL 237: Pottery on restoration

PI. LIX. Basarabi type pottery discovered at Tărtăria-Podu Tărtăriei vest

PI. LX. Basarabi type pottery discovered at Tărtăria-Podu Tărtăriei vest

CORINA BORȘ, LUCIANA IRIMUS, VLAD RUMEGA, SEBASTIAN DOBROTÃ

Muzeul Naţional de Istorie a României, Secției de Arheologie Pre- şi Protoistorică, Clasică și Medievală corina.bors73@gmail.com; luciana_dr@yahoo.com; vladrumega@gmail.com CÃTÃLIN RIŞCUTA

Muzeul Civilizației Dacice și Romane Strada 1 Decembrie, 39, Deva 


\begin{tabular}{|c|c|c|c|c|c|c|c|c|c|c|}
\hline $\begin{array}{c}\text { Siglă } \\
\text { complex }\end{array}$ & $\begin{array}{l}\text { Ceramich } \\
\text { atípică }\end{array}$ & $\begin{array}{c}\text { Ceramică } \\
\text { tipică }\end{array}$ & $\begin{array}{l}\text { Vase întregi } \\
\text { sau } \\
\text { intregibile }\end{array}$ & $\begin{array}{l}\text { Fragmente } \\
\text { chirpici }\end{array}$ & $\begin{array}{l}\text { Fragmente } \\
\text { oase } \\
\text { animal }\end{array}$ & $\begin{array}{c}\text { Oase } \\
\text { prelucrate }\end{array}$ & $\begin{array}{l}\text { Ceramică } \\
\text { - alte } \\
\text { categorii }\end{array}$ & Bronz & Fier & $\begin{array}{c}\text { Piatră } \\
\text { prelucrată }\end{array}$ \\
\hline CPL 001 & & $\mathbf{x}$ & & & & & & & & \\
\hline CPL 002 & $\mathrm{X}$ & $x$ & & $\mathrm{X}$ & $\mathrm{x}$ & & & & & \\
\hline CPL 003 & $\mathbf{X}$ & $\mathrm{X}$ & & $\mathbf{X}$ & & & & & & $\mathbf{X}$ \\
\hline CPL 004 & $\mathrm{X}$ & $\mathrm{X}$ & $\mathrm{X}$ & $X$ & $\mathrm{X}$ & & & $\mathrm{X}$ & & \\
\hline CPL 005 & $\mathbf{X}$ & $\mathrm{X}$ & & & & & & & & \\
\hline CPL 006 & $\mathrm{X}$ & $\mathrm{X}$ & & $\mathrm{X}$ & & & & $\mathrm{X}$ & & \\
\hline CPL 007 & $\mathbf{X}$ & & & & & & & $X$ & & \\
\hline CPL 008 & & $\mathrm{X}$ & & & & & & & & \\
\hline CPL 009 & $\mathbf{X}$ & $\mathbf{X}$ & & & & & & & & \\
\hline CPL 010 & $\mathrm{X}$ & $x$ & & $\mathrm{X}$ & & & & & & \\
\hline \multicolumn{11}{|l|}{ CPL 011} \\
\hline CPL 012 & $x$ & $x$ & & $\mathrm{X}$ & & & $x$ & $\mathrm{X}$ & $\mathrm{X}$ & \\
\hline CPL 013 & $\mathbf{X}$ & $\mathbf{X}$ & $\mathrm{X}$ & $\mathbf{X}$ & $\mathbf{x}$ & & & & $\mathbf{x}$ & \\
\hline CPL 014 & $\mathrm{X}$ & $\mathrm{x}$ & $\mathrm{x}$ & & & & $\mathrm{x}$ & $x$ & & \\
\hline CPL 015 & $\mathbf{X}$ & $\mathbf{X}$ & & $\mathbf{X}$ & & & & $\mathbf{X}$ & & \\
\hline CPL 016 & $x$ & $X$ & & $X$ & & & & & & \\
\hline CPL 017 & $\mathbf{X}$ & $\mathbf{X}$ & $\mathrm{x}$ & & & & & & & \\
\hline CPL 018 & $\mathrm{X}$ & $X$ & $\mathrm{x}$ & & & & & & & \\
\hline CPL 019 & $\mathbf{X}$ & $\mathbf{X}$ & & $\mathbf{X}$ & $\mathbf{X}$ & & & $\mathbf{X}$ & & $\mathbf{X}$ \\
\hline CPL 020 & $\mathrm{X}$ & & $\mathrm{x}$ & & & & & & & \\
\hline CPL 021 & $\mathbf{x}$ & $\mathbf{X}$ & $\mathrm{x}$ & $\mathbf{x}$ & $\mathbf{x}$ & & & $x$ & & \\
\hline CPL 022 & $\mathrm{X}$ & $X$ & $\mathrm{x}$ & $\mathrm{X}$ & & & $\mathrm{X}$ & & & \\
\hline CPL 023 & & & $\mathbf{X}$ & & & & & & & \\
\hline CPL 024 & & & $\mathrm{X}$ & & & & & & & \\
\hline CPL 025 & $\mathbf{x}$ & $\mathbf{X}$ & $\mathrm{X}$ & $\mathrm{X}$ & $\mathbf{x}$ & & $\mathrm{X}$ & & & $\mathbf{x}$ \\
\hline CPL 026 & $\mathrm{X}$ & $\mathrm{X}$ & $\mathrm{X}$ & & & & & & & \\
\hline CPL 027 & & & $\mathbf{X}$ & & & & & & & \\
\hline CPL 028 & $\mathrm{X}$ & $X$ & $\mathrm{X}$ & & $\mathrm{x}$ & & & & & \\
\hline CPL 029 & $X$ & $\mathbf{X}$ & $\mathbf{X}$ & & & & & & & $\mathrm{X}$ \\
\hline CPL 030 & $x$ & $X$ & & & & & & & & \\
\hline CPL 031 & $\mathrm{X}$ & $\mathbf{X}$ & & & $\mathrm{X}$ & & $\mathbf{X}$ & & & \\
\hline CPL 032 & $x$ & & & & & & & & & \\
\hline CPL 033 & $\mathbf{X}$ & & & & & & & & & \\
\hline CPL 034 & $\mathrm{X}$ & $\mathrm{X}$ & & & & & & & & $\mathrm{X}$ \\
\hline CPL 035 & $\mathrm{X}$ & & & & & & & & & \\
\hline CPL 036 & $\mathrm{x}$ & $\mathrm{X}$ & & & & & & & & \\
\hline CPL 037 & $X$ & $\mathbf{x}$ & & & & & & & & \\
\hline
\end{tabular}




\begin{tabular}{|c|c|c|c|c|c|c|c|c|c|c|}
\hline $\begin{array}{c}\text { Siglă } \\
\text { complex }\end{array}$ & $\begin{array}{l}\text { Ceramică } \\
\text { atipicá }\end{array}$ & $\begin{array}{l}\text { Ceramică } \\
\text { tipicã }\end{array}$ & $\begin{array}{l}\text { Vase întregi } \\
\text { sau } \\
\text { intregibile }\end{array}$ & $\begin{array}{l}\text { Fragmente } \\
\text { chirpici }\end{array}$ & $\begin{array}{c}\text { Fragmente } \\
\text { oase } \\
\text { animal }\end{array}$ & $\begin{array}{c}\text { Oase } \\
\text { prelucrate }\end{array}$ & $\begin{array}{c}\text { Ceramicã } \\
\text { - alte } \\
\text { categorii }\end{array}$ & Bronz & Fier & $\begin{array}{c}\text { Piatră } \\
\text { prelucratã }\end{array}$ \\
\hline CPL 038 & $\mathrm{X}$ & $X$ & & & $\mathrm{X}$ & & & $\mathrm{X}$ & $\mathrm{x}$ & \\
\hline CPL 039 & $\mathbf{X}$ & $\mathbf{X}$ & $\mathrm{X}$ & $\mathbf{X}$ & $\mathbf{x}$ & & $\mathbf{x}$ & & & \\
\hline \multicolumn{11}{|l|}{ CPL 040} \\
\hline CPL 041 & $\mathbf{x}$ & $\mathbf{X}$ & & & & & & & & \\
\hline CPL 042 & $\mathrm{X}$ & $x$ & & & & & & & & \\
\hline CPL 043 & $\mathbf{X}$ & $\mathbf{X}$ & & & $\mathbf{x}$ & & & & & \\
\hline CPL 044 & & $\mathrm{X}$ & $\mathrm{X}$ & & & & & & & \\
\hline CPL 045 & $\mathbf{X}$ & $\mathbf{X}$ & $\mathrm{x}$ & & $\mathbf{X}$ & & & & & \\
\hline CPL 046 & $\mathrm{X}$ & $\mathrm{X}$ & & $\mathrm{X}$ & & & & & & \\
\hline CPL 047 & $\mathrm{x}$ & $\mathrm{X}$ & $\mathrm{x}$ & & & & & $\mathrm{X}$ & & \\
\hline CPL 048 & $\mathrm{X}$ & $\mathrm{X}$ & $\mathrm{X}$ & $\mathrm{X}$ & $\mathrm{X}$ & & $\mathrm{X}$ & & & $X$ \\
\hline CPL 049 & $\mathbf{X}$ & $\mathbf{X}$ & & $\mathbf{x}$ & & & & $\mathrm{x}$ & $\mathrm{x}$ & \\
\hline CPL 050 & $X$ & $X$ & & & $\mathrm{X}$ & & & & & \\
\hline CPL 051 & $\mathbf{X}$ & $\mathbf{x}$ & & & & & & & & \\
\hline CPL 052 & $X$ & $\mathrm{X}$ & $\mathrm{X}$ & & & & & & & \\
\hline CPL 053 & $\mathbf{X}$ & $\mathrm{X}$ & $\mathrm{X}$ & & & & & & & \\
\hline CPL 054 & $X$ & $X$ & & & & & & & & \\
\hline \multicolumn{11}{|l|}{ CPL 055} \\
\hline CPL 056 & $X$ & $\mathrm{X}$ & & & & & & & & \\
\hline CPL 057 & $\mathbf{X}$ & $\mathbf{X}$ & $\mathrm{X}$ & & & & & $\mathrm{x}$ & & \\
\hline CPL 058 & $\mathrm{x}$ & $\mathrm{X}$ & & & $\mathrm{X}$ & $\mathrm{x}$ & & & & \\
\hline \multicolumn{11}{|l|}{ CPL 059} \\
\hline CPL 060 & $\mathrm{X}$ & $\mathrm{X}$ & $\mathrm{x}$ & & & & & & & \\
\hline CPL 061 & $\mathbf{X}$ & $\mathbf{X}$ & $\mathrm{X}$ & & & & & & & \\
\hline CPL 062 & $X$ & $X$ & & $X$ & & & & & & \\
\hline CPL 063 & $\mathbf{X}$ & $\mathbf{X}$ & $\mathrm{X}$ & $\mathbf{x}$ & $\mathbf{x}$ & & $\mathbf{x}$ & & & \\
\hline CPL 064 & $x$ & & $\mathrm{x}$ & & & & & & & \\
\hline CPL 065 & $\mathrm{x}$ & & & & $\mathrm{x}$ & & & & & \\
\hline CPL 066 & $\mathrm{X}$ & $\mathrm{X}$ & & $\mathrm{x}$ & & & $\mathrm{X}$ & & & $\mathrm{x}$ \\
\hline CPL 067 & $\mathbf{X}$ & $\mathbf{X}$ & & & & & & & & \\
\hline CPL 068 & $\mathrm{X}$ & $\mathrm{X}$ & & & & & & & & \\
\hline CPL 069 & $\mathbf{X}$ & $\mathbf{X}$ & & $\mathbf{x}$ & & & & & & \\
\hline CPL 070 & $\mathrm{x}$ & $\mathrm{X}$ & $\mathrm{x}$ & $\mathrm{x}$ & $\mathrm{X}$ & & & $\mathrm{X}$ & $\mathrm{x}$ & $x$ \\
\hline CPL 071 & $\mathbf{X}$ & $\mathbf{X}$ & & & & & & & $\mathbf{x}$ & \\
\hline \multicolumn{11}{|l|}{ CPL 072} \\
\hline CPL 073 & $\mathrm{X}$ & & & & & & & & & \\
\hline CPL 074 & $\mathrm{X}$ & $\mathrm{X}$ & $\mathrm{X}$ & $\mathrm{x}$ & $\mathrm{X}$ & & $X$ & $\mathrm{X}$ & $\mathrm{x}$ & $\mathrm{X}$ \\
\hline CPL 075 & & & & & & & & & & \\
\hline
\end{tabular}




\begin{tabular}{|c|c|c|c|c|c|c|c|c|c|c|}
\hline $\begin{array}{c}\text { Siglà } \\
\text { complex }\end{array}$ & $\begin{array}{c}\text { Ceramică } \\
\text { atipicá }\end{array}$ & $\begin{array}{l}\text { Ceramică } \\
\text { tipică }\end{array}$ & $\begin{array}{l}\text { Vase întregi } \\
\text { sau } \\
\text { întregibile }\end{array}$ & $\begin{array}{c}\text { Fragmente } \\
\text { chirpici }\end{array}$ & $\begin{array}{c}\text { Fragmente } \\
\text { oase } \\
\text { animal }\end{array}$ & $\begin{array}{c}\text { Oase } \\
\text { prelucrate }\end{array}$ & $\begin{array}{c}\text { Ceramică } \\
\text { - alte } \\
\text { categorii }\end{array}$ & Bronz & Fier & $\begin{array}{c}\text { Piatră } \\
\text { prelucrată }\end{array}$ \\
\hline CPL 076 & & & & & & & & & $\mathrm{x}$ & \\
\hline CPL 077 & $\mathrm{x}$ & $\mathrm{x}$ & $x$ & & & & & & & \\
\hline CPL 078 & $x$ & $x$ & & $x$ & $\mathrm{x}$ & & & & $x$ & $\mathrm{x}$ \\
\hline CPL 079 & $\mathbf{x}$ & $\mathrm{x}$ & & & & & & & & \\
\hline CPL 080 & $\mathrm{x}$ & $\mathrm{x}$ & & & & & & $\mathrm{x}$ & & $x$ \\
\hline \multicolumn{11}{|l|}{ CPL 081} \\
\hline CPL 082 & $x$ & $x$ & & $x$ & $x$ & & & & & $x$ \\
\hline CPL 083 & $x$ & $x$ & & & & & & & & \\
\hline CPL 084 & $x$ & $x$ & $x$ & & $x$ & & & & & $x$ \\
\hline CPL 085 & $x$ & $X$ & & & & & & & & \\
\hline CPL 086 & $x$ & $x$ & $\bar{x}$ & & & & & & & \\
\hline CPL 087 & $x$ & $\bar{x}$ & & $x$ & & & & & & \\
\hline CPL 088 & $x$ & $x$ & $x$ & $x$ & & & & & & \\
\hline CPL 089 & $x$ & $x$ & & & & & & $x$ & & \\
\hline CPL 090 & $x$ & $x$ & $x$ & & & & & & $\mathrm{x}$ & \\
\hline CPL 091 & $\mathrm{x}$ & & & & & & & & & \\
\hline \multicolumn{11}{|l|}{ CPL 092} \\
\hline CPL 093 & $x$ & $x$ & & & & & & & & \\
\hline CPL 094 & $x$ & $x$ & $x$ & & & & & & & \\
\hline CPL 095 & $x$ & & & & & & & & & \\
\hline CPL 096 & $x$ & & & & & & & & & \\
\hline CPL 097 & $x$ & $\mathrm{x}$ & & $x$ & $x$ & & & & & $x$ \\
\hline CPL 098 & $x$ & & $x$ & & $x$ & & & & & \\
\hline CPL 099 & $x$ & $x$ & & & & & & & & \\
\hline CPL 100 & $x$ & $x$ & & & & & & & & \\
\hline CPL 101 & $\bar{x}$ & $x$ & & & & & & & & \\
\hline \multicolumn{11}{|l|}{ CPL 102} \\
\hline CPL 103 & $x$ & $x$ & & & & & & & & \\
\hline CPL 104 & $x$ & $x$ & $x$ & & & & & & & \\
\hline CPL 105 & $x$ & $x$ & & & & & & $x$ & & \\
\hline \multicolumn{11}{|l|}{ CPL 106} \\
\hline CPL 107 & $x$ & $\mathrm{x}$ & $\mathrm{x}$ & $x$ & $\mathrm{x}$ & & & & & \\
\hline CPL 108 & $x$ & $x$ & & $x$ & & & & & & \\
\hline CPL 109 & $x$ & & & $x$ & & & & & & \\
\hline CPL 110 & $x$ & $x$ & & $x$ & $\mathrm{x}$ & & $x$ & & & \\
\hline \multicolumn{11}{|l|}{ CPL 111} \\
\hline \multicolumn{11}{|l|}{ CPL 112} \\
\hline CPL 113 & & & & & & & & & & \\
\hline
\end{tabular}




\begin{tabular}{|c|c|c|c|c|c|c|c|c|c|c|}
\hline $\begin{array}{c}\text { Siglax } \\
\text { complex }\end{array}$ & $\begin{array}{l}\text { Ceranică } \\
\text { atipicá }\end{array}$ & $\begin{array}{c}\text { Ceramicà } \\
\text { tipică }\end{array}$ & $\begin{array}{l}\text { Vase întregi } \\
\text { sau } \\
\text { întregibile }\end{array}$ & $\begin{array}{c}\text { Fragmente } \\
\text { chirpici }\end{array}$ & $\begin{array}{c}\text { Fragmente } \\
\text { oase } \\
\text { animal }\end{array}$ & $\begin{array}{c}\text { Oase } \\
\text { prelucrate }\end{array}$ & $\begin{array}{c}\text { Ceramicå } \\
\text { - alte } \\
\text { categorii }\end{array}$ & Bronz & Fier & $\begin{array}{c}\text { Piatră } \\
\text { prelucratã }\end{array}$ \\
\hline $\begin{array}{c}\text { CPL 114 } \\
\text { (MI - M7) }\end{array}$ & $\mathrm{x}$ & $\mathrm{x}$ & & $\mathrm{x}$ & & & & $\mathrm{x}$ & $\mathrm{x}$ & \\
\hline $\begin{array}{c}\text { CPL 114 } \\
\text { B }\end{array}$ & $\mathrm{x}$ & $\mathrm{x}$ & $x$ & & & & $\mathrm{x}$ & & & \\
\hline CPL 115 & $x$ & $\mathrm{X}$ & $x$ & $\mathrm{x}$ & & & & $x$ & & $\mathrm{x}$ \\
\hline CPL 116 & $\bar{X}$ & $\bar{x}$ & $\bar{x}$ & & & & & $x$ & & \\
\hline CPL 117 & $x$ & $x$ & & & & & & & & \\
\hline CPL 118 & $x$ & $\mathrm{x}$ & $x$ & $x$ & & & & $x$ & & \\
\hline \multicolumn{11}{|l|}{ CPL 119} \\
\hline CPL 120 & $x$ & $\bar{x}$ & & 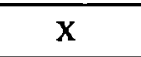 & & & & & $\mathrm{X}$ & $\bar{x}$ \\
\hline CPL 120B & $x$ & $x$ & $x$ & $x$ & $x$ & & $x$ & $x$ & $x$ & $x$ \\
\hline CPL 121 & $x$ & $x$ & $x$ & & & & & & & \\
\hline CPL 122 & $x$ & $x$ & $x$ & & & & & & & \\
\hline CPL 123 & $x$ & $\bar{x}$ & $\bar{x}$ & $x$ & & & $\mathrm{x}$ & $x$ & & \\
\hline \multicolumn{11}{|l|}{ CPL 124} \\
\hline CPL 125 & $x$ & $x$ & & & & & & & & \\
\hline \multicolumn{11}{|l|}{ CPL 126} \\
\hline CPL 127 & $x$ & $x$ & & $x$ & & & & $\mathbf{X}$ & $x$ & $\mathrm{x}$ \\
\hline CPL 128 & $x$ & $x$ & & & & & & & & \\
\hline \multicolumn{11}{|l|}{ CPL 129} \\
\hline \multicolumn{11}{|l|}{ CPL 130} \\
\hline \multicolumn{11}{|l|}{ CPL 131} \\
\hline \multicolumn{11}{|l|}{ CPL 132} \\
\hline CPL 133 & $\mathrm{x}$ & $\bar{x}$ & & & & & & & & \\
\hline \multicolumn{11}{|l|}{ CPL 134} \\
\hline \multicolumn{11}{|l|}{ CPL 135} \\
\hline CPL 136 & $x$ & $x$ & $x$ & & & & & $x$ & & \\
\hline CPL 137 & $x$ & $x$ & & & & & & $\mathrm{x}$ & & \\
\hline \multicolumn{11}{|l|}{ CPL 138} \\
\hline CPL 139 & $x$ & $\mathrm{x}$ & & & & & & & & \\
\hline CPL 140 & $x$ & $x$ & & & & & & & & \\
\hline CPL 141 & $\mathrm{x}$ & $\mathrm{x}$ & $\mathrm{x}$ & & & & & & $\mathrm{x}$ & \\
\hline CPL 142 & $x$ & $x$ & $x$ & & & & & & & \\
\hline CPL 143 & & $x$ & & & & & & & & \\
\hline CPL 144 & $\bar{x}$ & $x$ & & & & & & & & \\
\hline CPL 145 & $x$ & $x$ & $x$ & & & & & $\mathbf{x}$ & & \\
\hline CPL 146 & $x$ & & & & & & & & & \\
\hline CPL 147 & $x$ & $\mathrm{x}$ & $\mathrm{x}$ & & $\mathrm{x}$ & & & & $\mathrm{x}$ & \\
\hline
\end{tabular}




\begin{tabular}{|c|c|c|c|c|c|c|c|c|c|c|}
\hline $\begin{array}{c}\text { Siglă } \\
\text { complex }\end{array}$ & $\begin{array}{c}\text { Ceramică } \\
\text { atipică }\end{array}$ & $\begin{array}{c}\text { Ceramică } \\
\text { tipică }\end{array}$ & $\begin{array}{l}\text { Vase întregi } \\
\text { sau } \\
\text { intregibile }\end{array}$ & $\begin{array}{l}\text { Fragmente } \\
\text { chirpici }\end{array}$ & $\begin{array}{c}\text { Fragmente } \\
\text { oase } \\
\text { animal }\end{array}$ & $\begin{array}{c}\text { Oase } \\
\text { prelucrate }\end{array}$ & $\begin{array}{c}\text { Ceramică } \\
\text { - alte } \\
\text { categorii }\end{array}$ & Bronz & Fier & $\begin{array}{c}\text { Piatră } \\
\text { prelucrată }\end{array}$ \\
\hline CPL 148 & $X$ & $\mathrm{X}$ & & $\mathrm{x}$ & & & & & & \\
\hline CPL 149 & $\mathrm{X}$ & $\mathrm{X}$ & $\mathbf{X}$ & $\mathbf{X}$ & $\mathbf{X}$ & & & $\mathbf{X}$ & & \\
\hline CPL 150 & $\mathrm{X}$ & $x$ & & & $\mathrm{x}$ & & & $x$ & & \\
\hline CPL 151 & $\mathbf{X}$ & $\mathbf{X}$ & $\mathbf{X}$ & $\mathbf{x}$ & & & $\mathbf{x}$ & & $\mathrm{X}$ & $\mathrm{x}$ \\
\hline CPL 152 & $\mathrm{X}$ & $\mathrm{x}$ & $\mathrm{X}$ & & & & & & & \\
\hline CPL 153 & $\mathbf{x}$ & $\mathrm{X}$ & $\mathrm{X}$ & $\mathbf{X}$ & & & $\mathrm{x}$ & $\mathbf{X}$ & $\mathbf{X}$ & \\
\hline CPL 154 & $\mathrm{X}$ & $\mathrm{x}$ & & $\mathrm{X}$ & & & & $x$ & & \\
\hline CPL 155 & $\mathrm{X}$ & $\mathrm{X}$ & $\mathbf{X}$ & $\mathbf{X}$ & & & & & & \\
\hline CPL 156 & $\mathrm{X}$ & $\mathrm{X}$ & $\mathrm{X}$ & $X$ & & & $\mathrm{X}$ & & & \\
\hline CPL 157 & $\mathbf{x}$ & & & & & & & & & \\
\hline CPL 158 & $X$ & $\mathrm{X}$ & & $X$ & & & & & & \\
\hline CPL 159 & $\mathbf{X}$ & $\mathbf{X}$ & & $\mathbf{X}$ & & & & & & \\
\hline CPL 160 & $\mathrm{X}$ & $\mathrm{X}$ & & $X$ & & & & & & $\mathrm{X}$ \\
\hline CPL 161 & $\mathbf{X}$ & $\mathbf{X}$ & $x$ & & $\mathbf{X}$ & & & & & \\
\hline CPL 162 & $\mathrm{X}$ & & & & & & & & & \\
\hline CPL 163 & $\mathbf{X}$ & $\mathbf{X}$ & & & & & & $x$ & & \\
\hline CPL 164 & $\mathrm{X}$ & $x$ & & & & & & & & \\
\hline CPL 165 & $\mathbf{x}$ & $\mathbf{X}$ & $\mathrm{X}$ & & $\mathbf{X}$ & & & & & \\
\hline CPL 166 & $x$ & $\mathrm{X}$ & & & & & & & & \\
\hline CPL 167 & $X$ & $\mathbf{X}$ & $\mathrm{x}$ & & $\mathbf{x}$ & & & & & \\
\hline CPL 168 & $x$ & $\mathrm{X}$ & & $\mathrm{x}$ & & & & & & \\
\hline CPL 169 & $\mathbf{X}$ & $\mathbf{X}$ & & & & & & & & \\
\hline CPL 170 & $\mathrm{X}$ & $\mathrm{X}$ & & $\mathrm{X}$ & $\mathrm{X}$ & & & & & \\
\hline CPL 171 & $x$ & $\mathrm{x}$ & $\mathrm{X}$ & $\mathbf{x}$ & & & $x$ & & $\mathrm{X}$ & \\
\hline CPL 172 & $\mathrm{x}$ & $X$ & $\mathrm{X}$ & $\mathrm{X}$ & $\mathrm{X}$ & & & $x$ & $\mathrm{X}$ & $x$ \\
\hline CPL 173 & $\mathrm{x}$ & $\mathbf{x}$ & & & & & & & & \\
\hline CPL 174 & $\mathrm{x}$ & $\mathrm{X}$ & & & $\mathrm{x}$ & & & & & \\
\hline CPL 175 & $x$ & & & & & & & & & \\
\hline CPL 176 & $\mathrm{x}$ & $X$ & $\mathrm{X}$ & $\mathrm{x}$ & $x$ & & $\mathrm{X}$ & & & \\
\hline CPL 177 & $\mathrm{x}$ & $\mathrm{X}$ & & & $\mathbf{x}$ & & & & & \\
\hline \multicolumn{11}{|l|}{ CPL 178} \\
\hline CPL 179 & $\mathrm{X}$ & $\mathbf{X}$ & & $\mathrm{X}$ & $\mathbf{X}$ & & & & & \\
\hline \multicolumn{11}{|l|}{ CPL 180} \\
\hline CPL 181 & $x$ & $\mathrm{X}$ & & $\mathbf{X}$ & & & & $x$ & & $\mathrm{X}$ \\
\hline CPL 182 & $x$ & $x$ & $x$ & $x$ & & & & $x$ & & \\
\hline CPL 183 & $\mathrm{X}$ & $\mathbf{x}$ & & $\mathrm{X}$ & & & & $\mathrm{X}$ & & \\
\hline CPL 184 & $\mathrm{X}$ & $\mathrm{X}$ & & & $\mathrm{X}$ & & & & & \\
\hline CPL 185 & & & & & & & & & & \\
\hline
\end{tabular}




\begin{tabular}{|c|c|c|c|c|c|c|c|c|c|c|}
\hline $\begin{array}{c}\text { Siglă } \\
\text { complex }\end{array}$ & $\begin{array}{c}\text { Ceramică } \\
\text { atịpich }\end{array}$ & $\begin{array}{c}\text { Ceramică } \\
\text { tipică }\end{array}$ & $\begin{array}{c}\text { Vase întregi } \\
\text { sau } \\
\text { întregibile }\end{array}$ & $\begin{array}{c}\text { Fragmente } \\
\text { chirpici }\end{array}$ & $\begin{array}{c}\text { Fragmente } \\
\text { oase } \\
\text { animal }\end{array}$ & $\begin{array}{c}\text { Oase } \\
\text { prelucrate }\end{array}$ & $\begin{array}{c}\text { Ceramică } \\
\text { - alte } \\
\text { categorii }\end{array}$ & Bronz & Fier & $\begin{array}{c}\text { Piatră } \\
\text { prelucrată }\end{array}$ \\
\hline CPL 186 & $\mathrm{X}$ & $\mathrm{X}$ & $\mathrm{X}$ & & & & & & & \\
\hline CPL 187 & $\mathbf{X}$ & $\mathbf{X}$ & & & & & & & & \\
\hline \multicolumn{11}{|l|}{ CPL 188} \\
\hline \multicolumn{11}{|l|}{ CPL 189} \\
\hline CPL 190 & $\mathrm{X}$ & $\mathrm{X}$ & $\mathrm{x}$ & & & & & & & \\
\hline CPL 191 & $\mathbf{X}$ & $\mathrm{X}$ & & $\mathbf{X}$ & $\mathbf{X}$ & & & & & \\
\hline CPL 192 & $\mathrm{X}$ & $x$ & & $\mathrm{X}$ & & & & $\mathrm{X}$ & $\mathrm{X}$ & \\
\hline CPL 193 & $\mathbf{X}$ & $\mathbf{X}$ & & & & & & $\mathrm{X}$ & & \\
\hline \multicolumn{11}{|l|}{ CPL 194} \\
\hline \multicolumn{11}{|l|}{ CPL 195} \\
\hline CPL 196 & $\mathrm{X}$ & $\mathrm{X}$ & & $x$ & $\mathrm{X}$ & & & & $\mathrm{X}$ & \\
\hline \multicolumn{11}{|l|}{ CPL 197} \\
\hline CPL 198 & $\mathrm{X}$ & $\mathrm{X}$ & & & & & & & & \\
\hline CPL 199 & $\mathbf{x}$ & $\mathbf{X}$ & & $\mathbf{X}$ & $\mathbf{X}$ & $\mathbf{X}$ & & & & \\
\hline CPL 200 & $x$ & $\mathrm{X}$ & & & & & & & & \\
\hline CPL 201 & $\mathbf{X}$ & $\mathbf{X}$ & & $\mathbf{x}$ & & & $\mathrm{X}$ & & & \\
\hline CPL 202 & $\mathrm{X}$ & $\mathrm{X}$ & & $\mathrm{X}$ & & & & $\mathrm{x}$ & $\mathrm{X}$ & \\
\hline CPL 203 & $\mathbf{x}$ & $\mathbf{X}$ & & & & & & & & \\
\hline CPL 204 & $\mathrm{x}$ & $\mathrm{X}$ & & $\mathrm{x}$ & $\mathrm{x}$ & & & & & \\
\hline CPL 205 & $\mathbf{X}$ & $\mathbf{X}$ & $\mathbf{X}$ & & & & & & & \\
\hline CPL 206 & $\mathrm{x}$ & $\mathrm{X}$ & & $\mathrm{x}$ & & & & & & \\
\hline \multicolumn{11}{|l|}{ CPL 207} \\
\hline CPL 208 & $\mathrm{x}$ & $\mathrm{X}$ & & & & & & & & \\
\hline CPL 209 & $\mathbf{X}$ & $\mathbf{X}$ & & $\mathrm{X}$ & & & & & & \\
\hline CPL 210 & $\mathrm{x}$ & $\mathrm{X}$ & & & & & & & & \\
\hline CPL 211 & $\mathrm{X}$ & $\mathbf{x}$ & & & & & & & & \\
\hline CPL 212 & $\mathrm{x}$ & $\mathrm{X}$ & $\mathrm{X}$ & $\mathrm{x}$ & & & $\mathrm{X}$ & $\mathrm{X}$ & & \\
\hline CPL 213 & $\mathbf{X}$ & $\mathbf{X}$ & $\mathbf{X}$ & & & & & & & \\
\hline \multicolumn{11}{|l|}{ CPL 214} \\
\hline \multicolumn{11}{|l|}{ CPL 215} \\
\hline CPL 216 & $\mathrm{X}$ & $\mathrm{X}$ & & & & & & & & \\
\hline CPL 217 & $\mathbf{X}$ & $\mathbf{X}$ & & & & & & & & \\
\hline CPL 218 & & & $\mathrm{X}$ & & & & & & & \\
\hline CPL 219 & $\mathbf{X}$ & & & & & & & & & \\
\hline CPL 220 & $X$ & $\mathrm{X}$ & $\mathrm{X}$ & $\mathrm{X}$ & & & $\mathrm{X}$ & & & $\mathrm{X}$ \\
\hline CPL 221 & $\mathbf{x}$ & $\mathbf{X}$ & & & & & & & & \\
\hline \multicolumn{11}{|l|}{ CPL 222} \\
\hline CPL 223 & $\mathbf{x}$ & $\mathbf{X}$ & & & $\mathbf{x}$ & $\mathbf{X}$ & & & & $\mathbf{X}$ \\
\hline
\end{tabular}




\begin{tabular}{|c|c|c|c|c|c|c|c|c|c|c|}
\hline $\begin{array}{c}\text { Siglã } \\
\text { complex }\end{array}$ & $\begin{array}{c}\text { Ceramică } \\
\text { atipicáa }\end{array}$ & $\begin{array}{c}\text { Ceramică } \\
\text { tipică }\end{array}$ & $\begin{array}{l}\text { Vase întregi } \\
\text { sau } \\
\text { întregibile }\end{array}$ & $\begin{array}{l}\text { Fragmente } \\
\text { chirpici }\end{array}$ & $\begin{array}{c}\text { Fragmente } \\
\text { oase } \\
\text { animal }\end{array}$ & $\begin{array}{c}\text { Oase } \\
\text { prelucrate }\end{array}$ & $\begin{array}{c}\text { Ceramică } \\
\text { - alte } \\
\text { categorii }\end{array}$ & Bronz & Fier & $\begin{array}{c}\text { Piatră } \\
\text { prelucrată }\end{array}$ \\
\hline CPL 224 & $\mathrm{x}$ & $\mathrm{x}$ & & $\mathrm{x}$ & & & & & & \\
\hline CPL 225 & $\mathbf{x}$ & $\mathbf{x}$ & & & & & & & & \\
\hline CPL 226 & $\mathrm{x}$ & $x$ & & $x$ & & & & & & \\
\hline CPL 227 & $\mathbf{x}$ & $\mathbf{x}$ & & $\mathbf{x}$ & & & & & & \\
\hline CPL 228 & $x$ & $x$ & & $x$ & & & & & & \\
\hline CPL 229 & $x$ & $x$ & & $\mathbf{x}$ & & & & & & \\
\hline CPL 230 & $x$ & $\mathrm{X}$ & & $\mathrm{X}$ & & & & $\mathrm{x}$ & & \\
\hline CPL 231 & $x$ & $\mathbf{x}$ & & & & & & & & \\
\hline CPL 232 & $x$ & $x$ & $x$ & $x$ & & & $x$ & & & \\
\hline CPL 233 & $\mathbf{x}$ & $\mathbf{x}$ & & $\mathbf{x}$ & & & & $\mathrm{x}$ & & \\
\hline CPL 234 & $x$ & $x$ & & & $x$ & & & & & \\
\hline CPL 235 & $\bar{x}$ & $\mathbf{x}$ & & $\mathbf{x}$ & & & & & & \\
\hline CPL 236 & $\bar{x}$ & $\mathrm{x}$ & & $x$ & & & & & & \\
\hline CPL 237 & $\bar{x}$ & $\mathrm{x}$ & $\bar{x}$ & $x$ & & & & & & \\
\hline CPL 238 & $x$ & $x$ & & $x$ & & & & & & \\
\hline CPL 239 & $x$ & $\mathrm{x}$ & & $\mathbf{x}$ & & & & & & \\
\hline CPL 240 & $x$ & $x$ & & $\mathrm{X}$ & & & & & & \\
\hline CPL 241 & $x$ & $x$ & & $\mathbf{x}$ & $\bar{x}$ & & & & & \\
\hline CPL 242 & $x$ & $\mathrm{x}$ & & $x$ & & & & & & \\
\hline CPL 243 & $x$ & $\mathbf{x}$ & $x$ & $x$ & $\mathbf{x}$ & & $x$ & & & \\
\hline CPL 244 & $x$ & $x$ & & $x$ & & & & & & \\
\hline CPL 245 & $x$ & $\mathrm{x}$ & $\bar{x}$ & $\mathrm{x}$ & & & & & & \\
\hline CPL 246 & $x$ & $x$ & $x$ & $x$ & & & & & & \\
\hline CPL 247 & $x$ & $\mathrm{x}$ & $x$ & $x$ & & & & & & $x$ \\
\hline CPL 248 & $x$ & $x$ & & $x$ & & & & & & \\
\hline CPL 249 & $x$ & $\mathbf{x}$ & $x$ & $x$ & $\mathbf{x}$ & & & & & \\
\hline CPL 250 & $x$ & $x$ & & & & & & & & \\
\hline CPL 251 & $\bar{x}$ & $\mathbf{x}$ & $x$ & $\bar{x}$ & 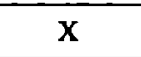 & & & & & \\
\hline CPL 252 & $x$ & $x$ & & & & & & & & \\
\hline CPL 253 & $x$ & $\mathbf{x}$ & & & & & & & & \\
\hline CPL 254 & $\mathrm{x}$ & $\mathrm{X}$ & $x$ & $x$ & $x$ & & & $\mathrm{x}$ & & $x$ \\
\hline CPL 255 & $x$ & $x$ & $x$ & $x$ & $x$ & & & & & \\
\hline CPL 256 & $\bar{x}$ & $x$ & & $x$ & & & & & & \\
\hline CPL 257 & $x$ & $\mathbf{x}$ & & $x$ & & & & & & \\
\hline CPL 258 & $x$ & $\mathrm{x}$ & & $x$ & & & & & & \\
\hline
\end{tabular}

Notă: Dat fiind stadiul actual al trierii materialului arheologic, pentru moment nu au fost incluse in tabel informatii privind materialul descoperit în stratul de cultură. 


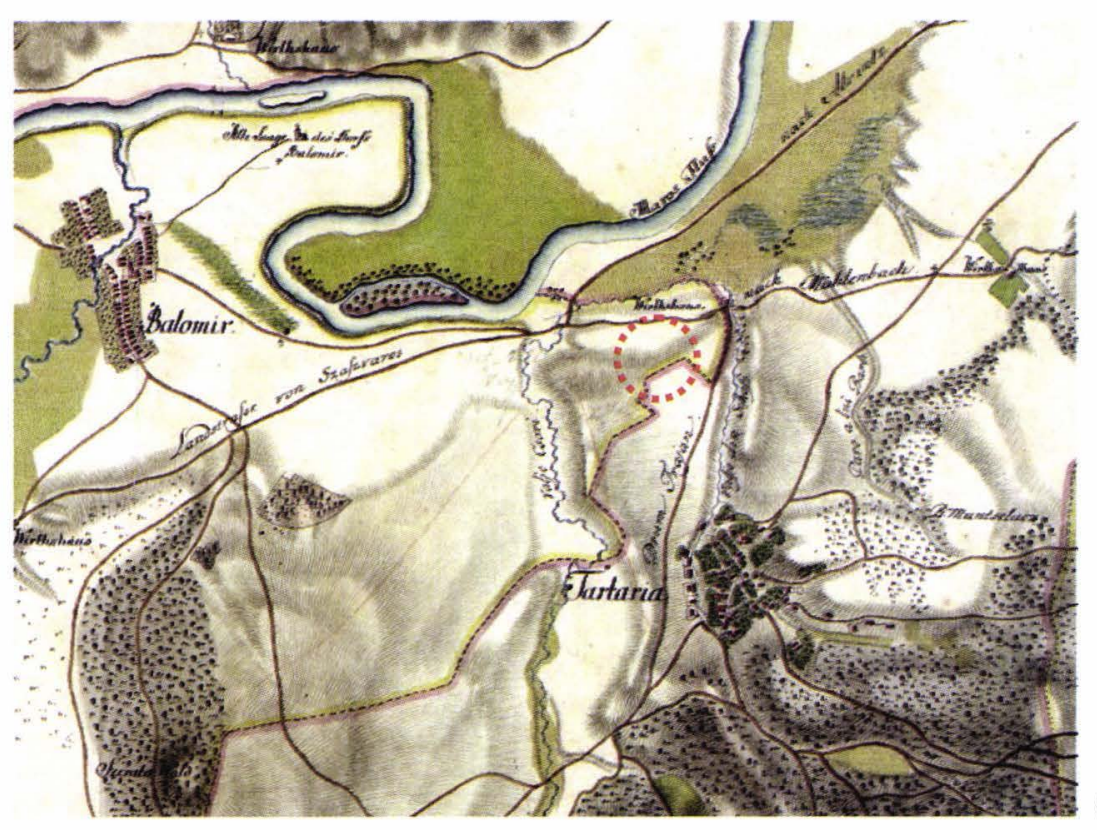

Harta iosefină a Transilvaniei (1769-1773)

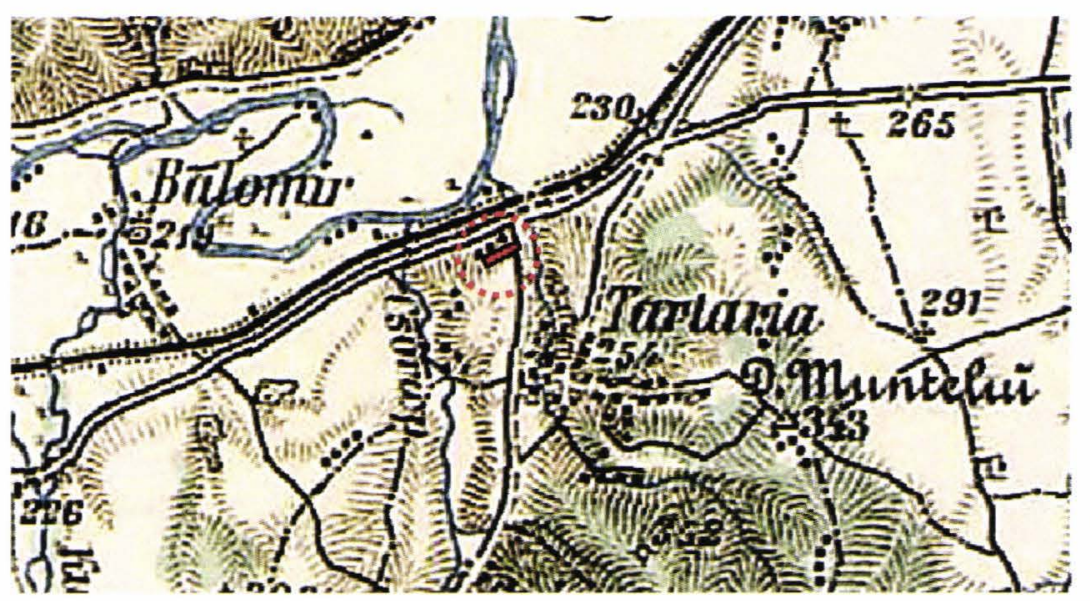

Harta austriaca (1869-1910)

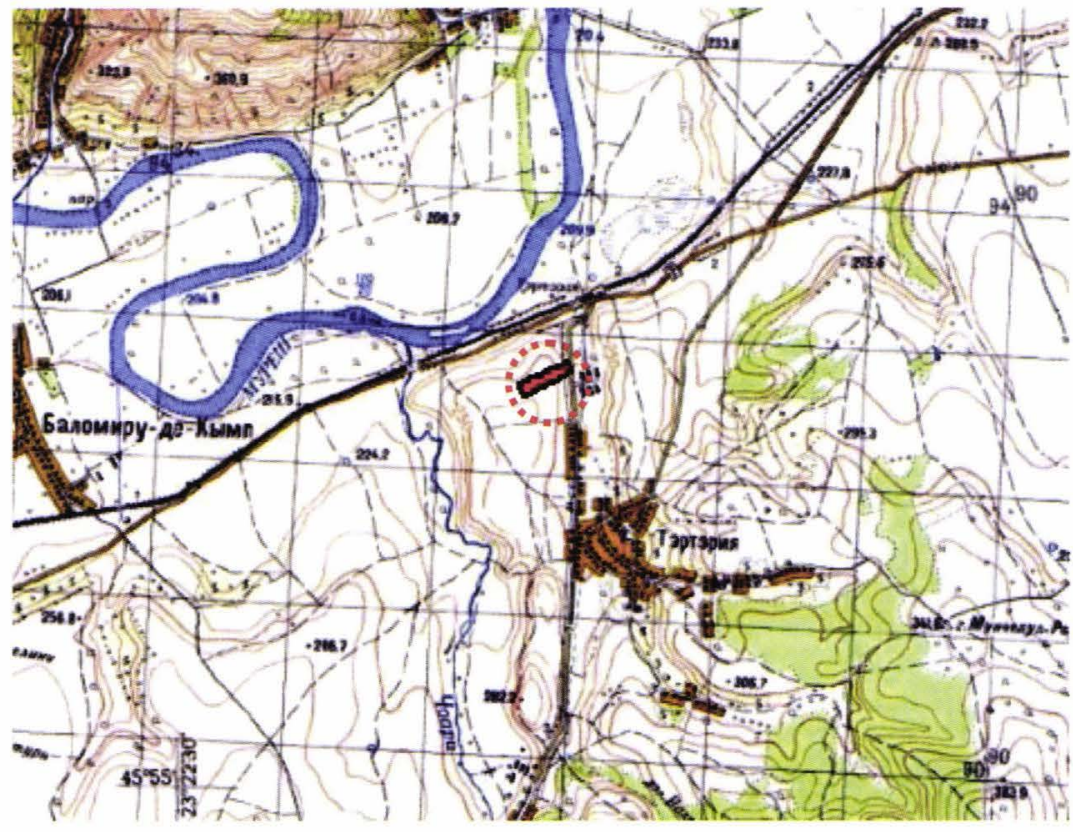

Hartă sovietică (după 1945)

Cartografierea zonei cercetate de-a lungul timpului 


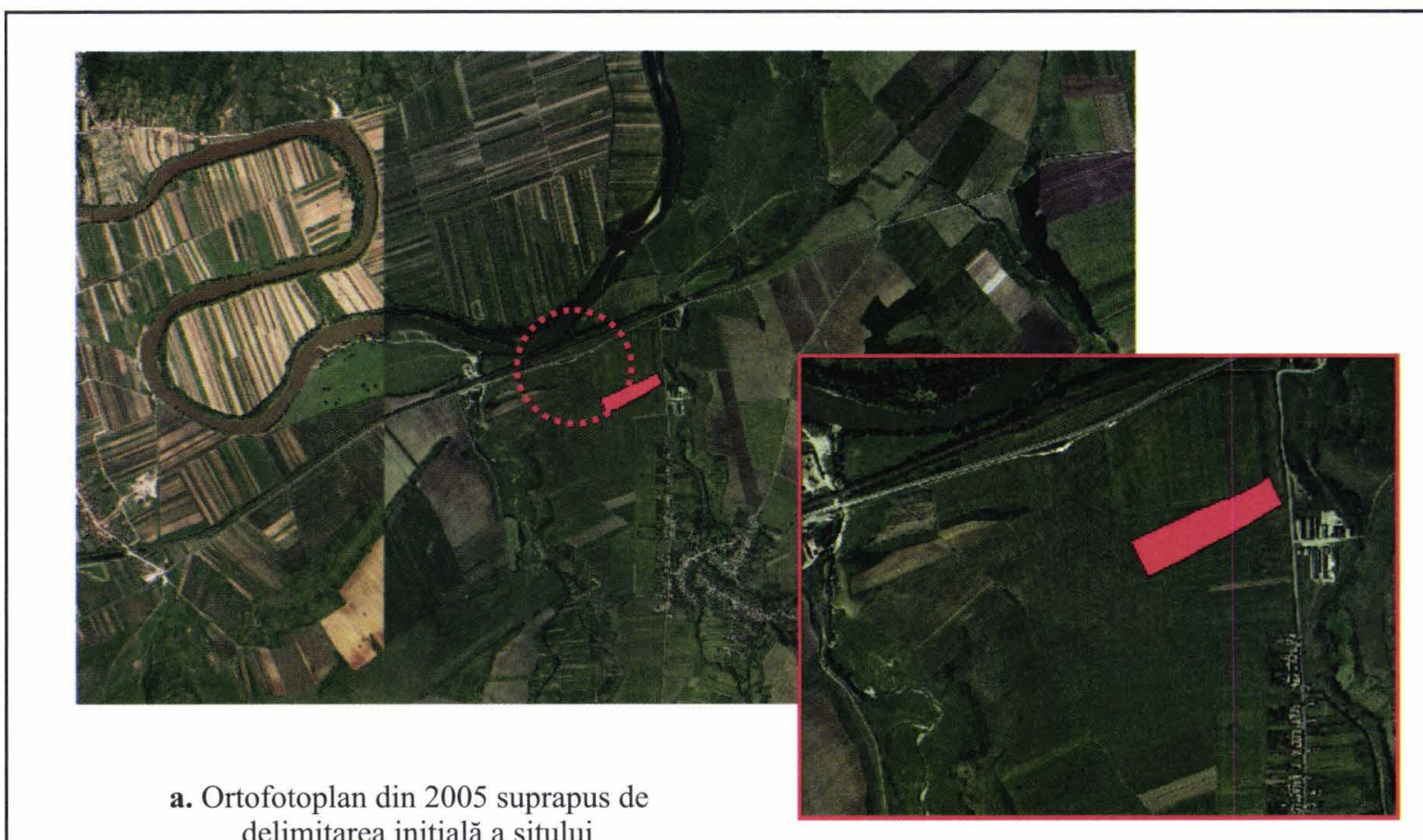

delimitarea inițială a sitului

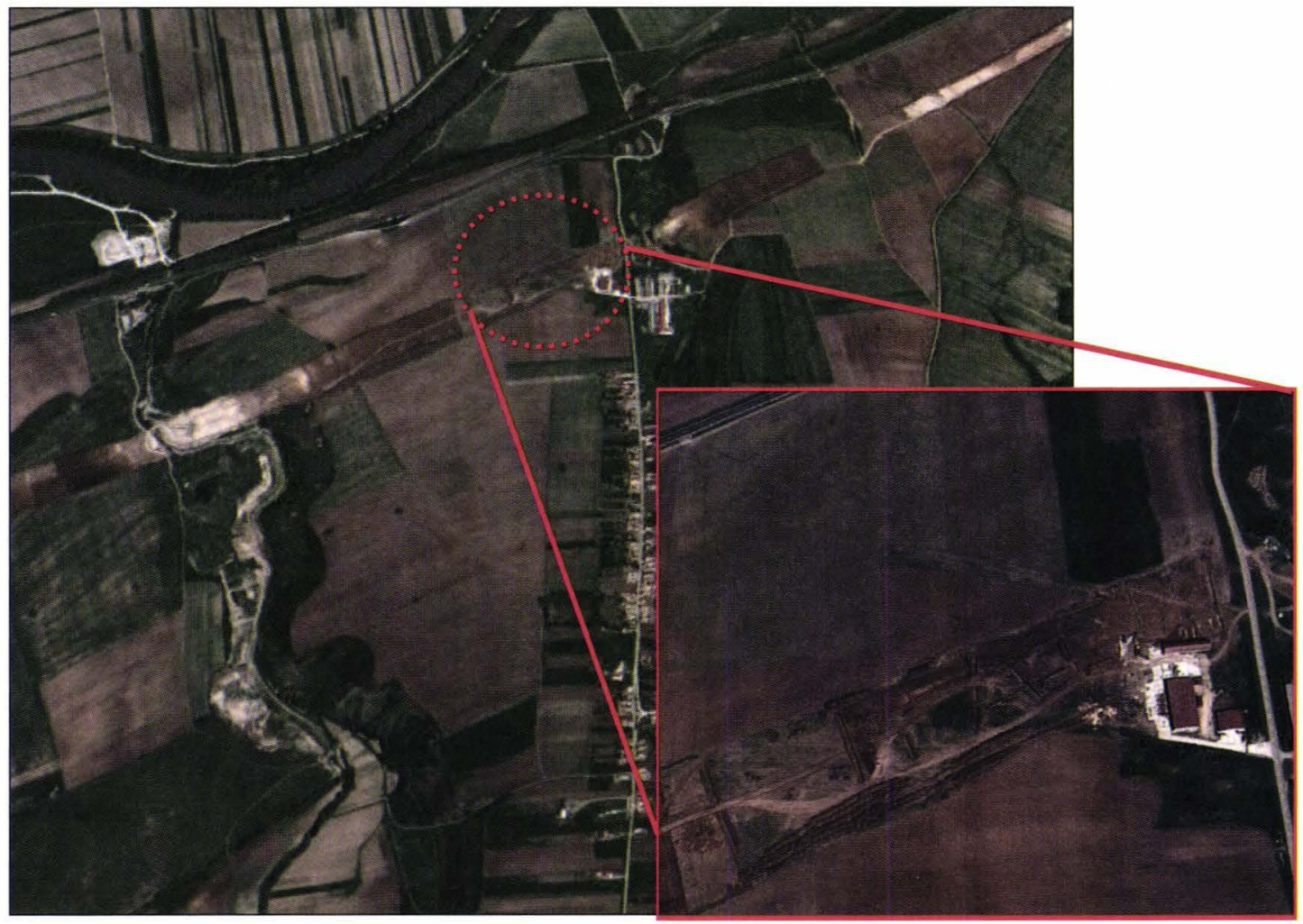

b. Imagine satelitară din 05.06 .2012

Încadrarea zonei cercetate pe ortofotoplanuri și imagini satelitare $(2005,2012)$ 


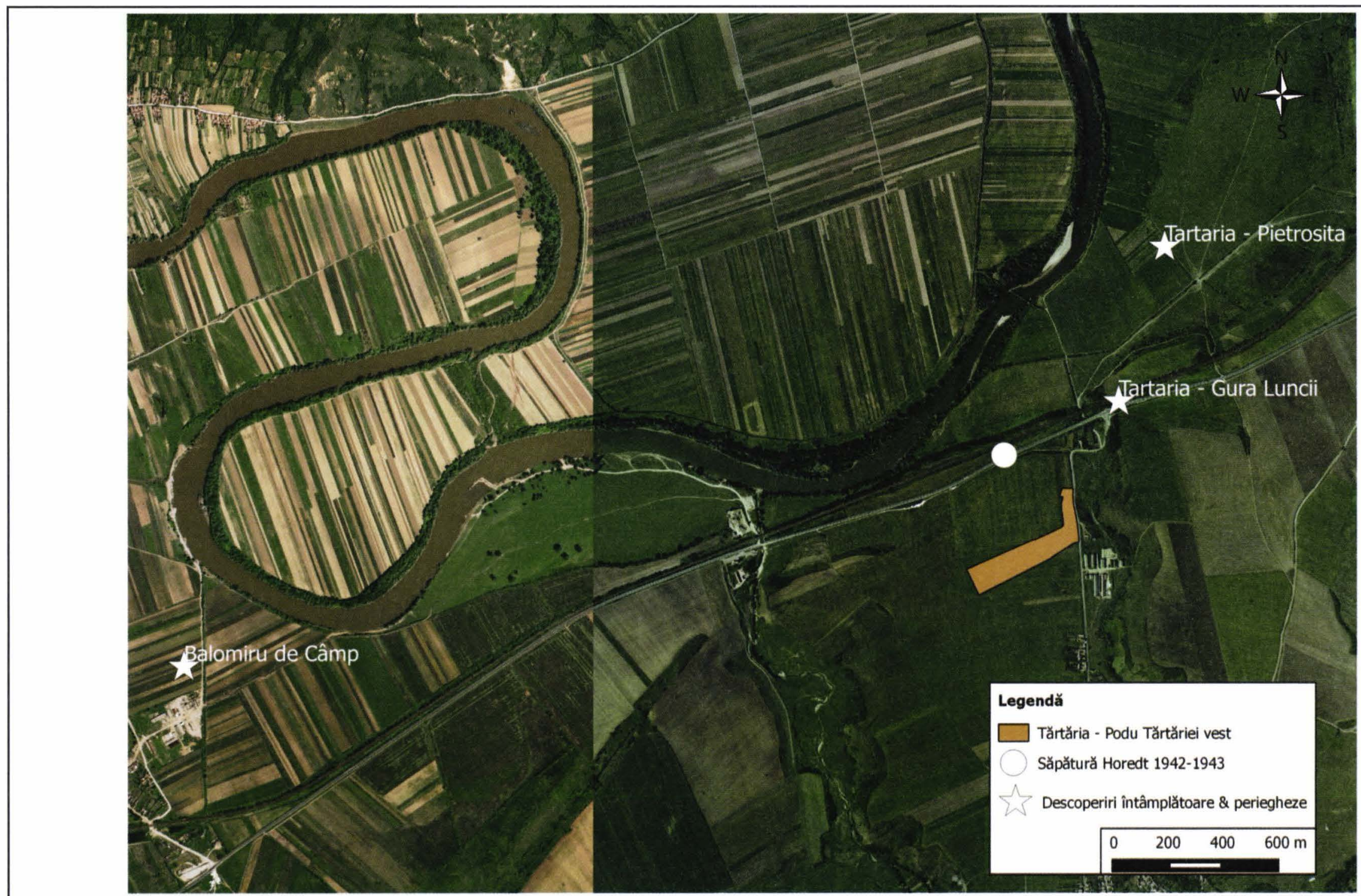

Descoperiri de tip Basarabi în imediata vecinătate a sitului Tărtăria-Podu Tărtăriei vest

PI. III 


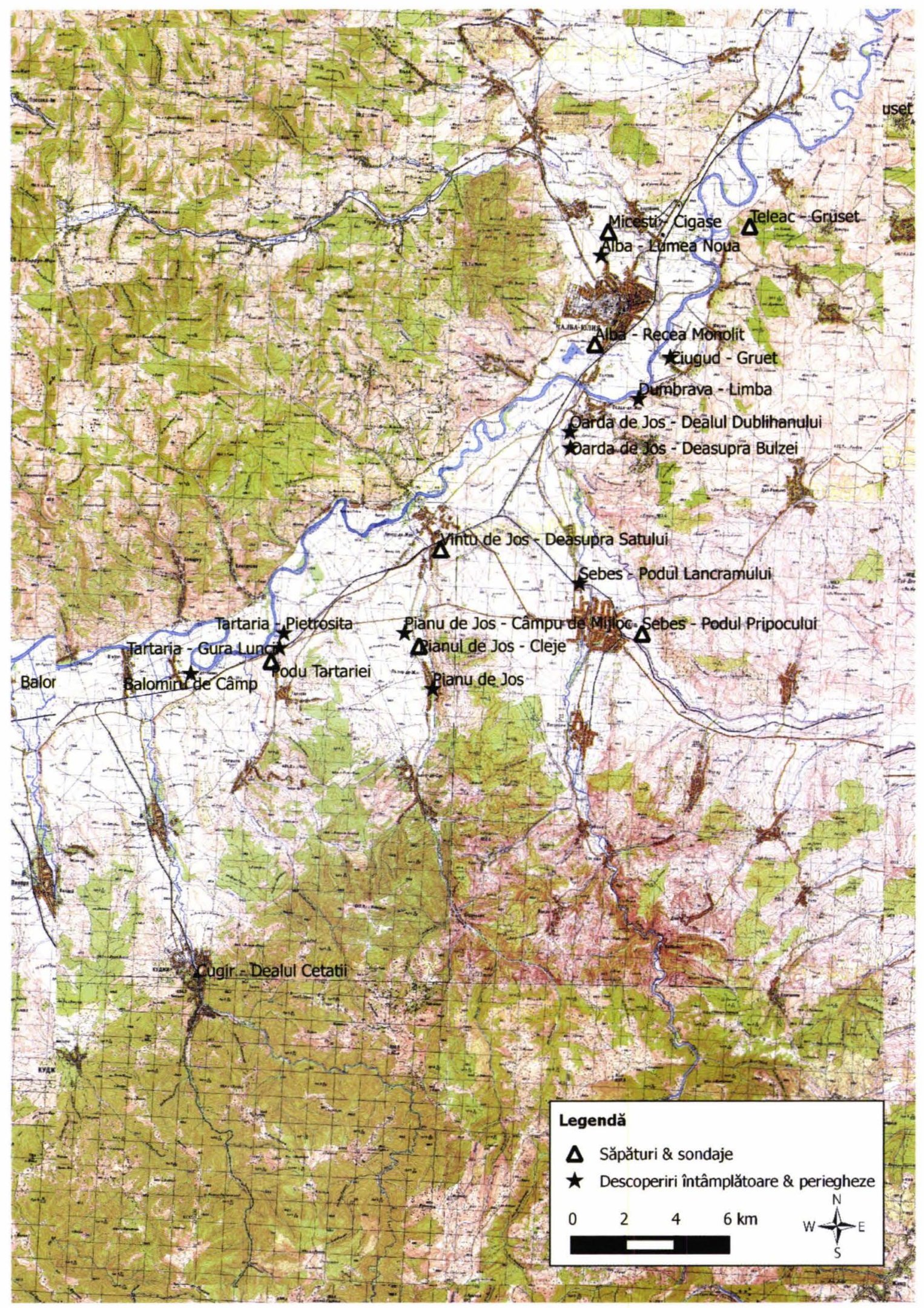

Descoperiri de tip Basarabi în zona Orăștie-Alba Iulia 


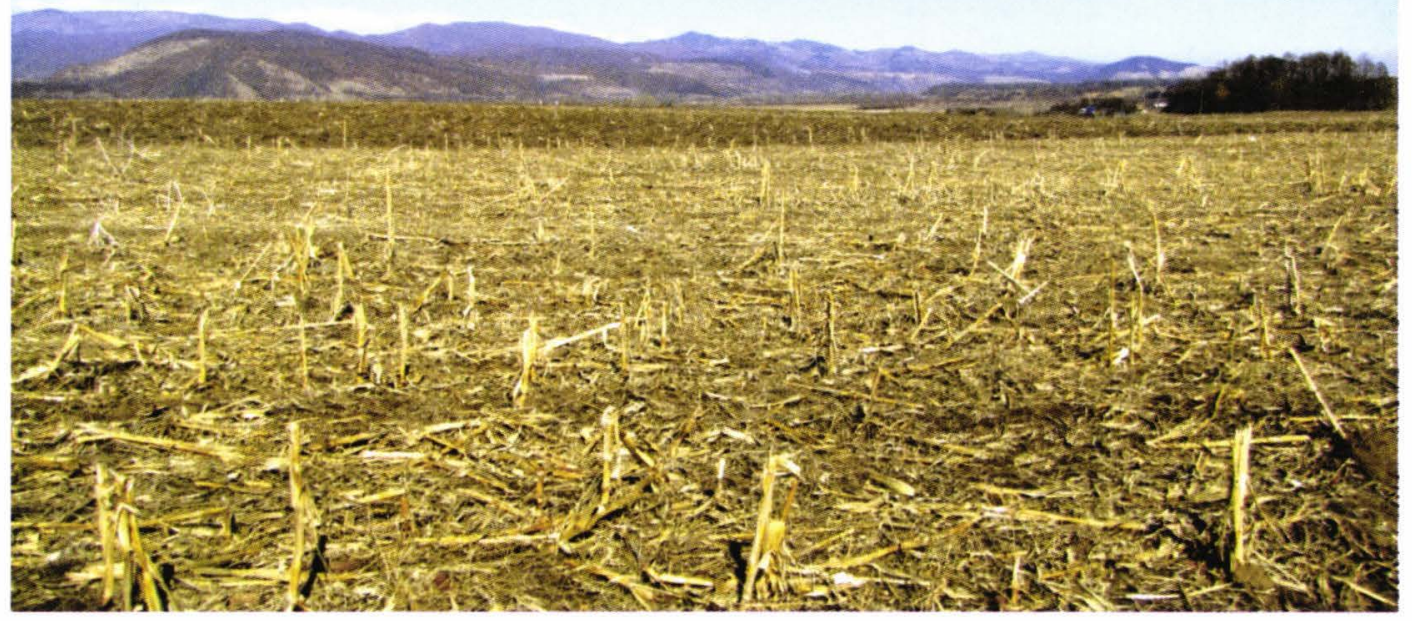

a

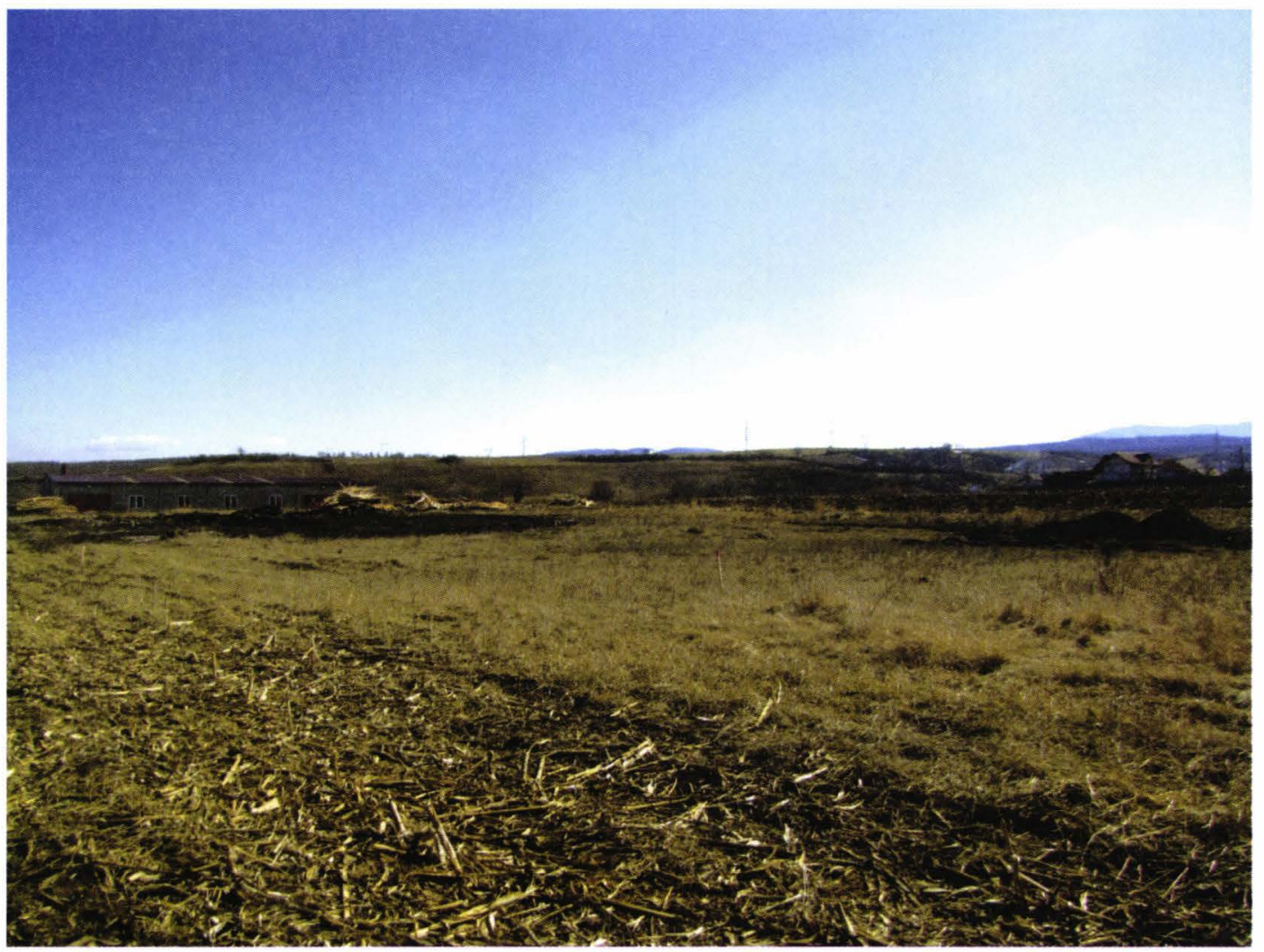

b

Imagini de ansamblu ale zonei sitului înainte de începerea săpăturii. a. Vedere spre N către valea Mureșului b.Vedere spre S către satul Tărtăria 

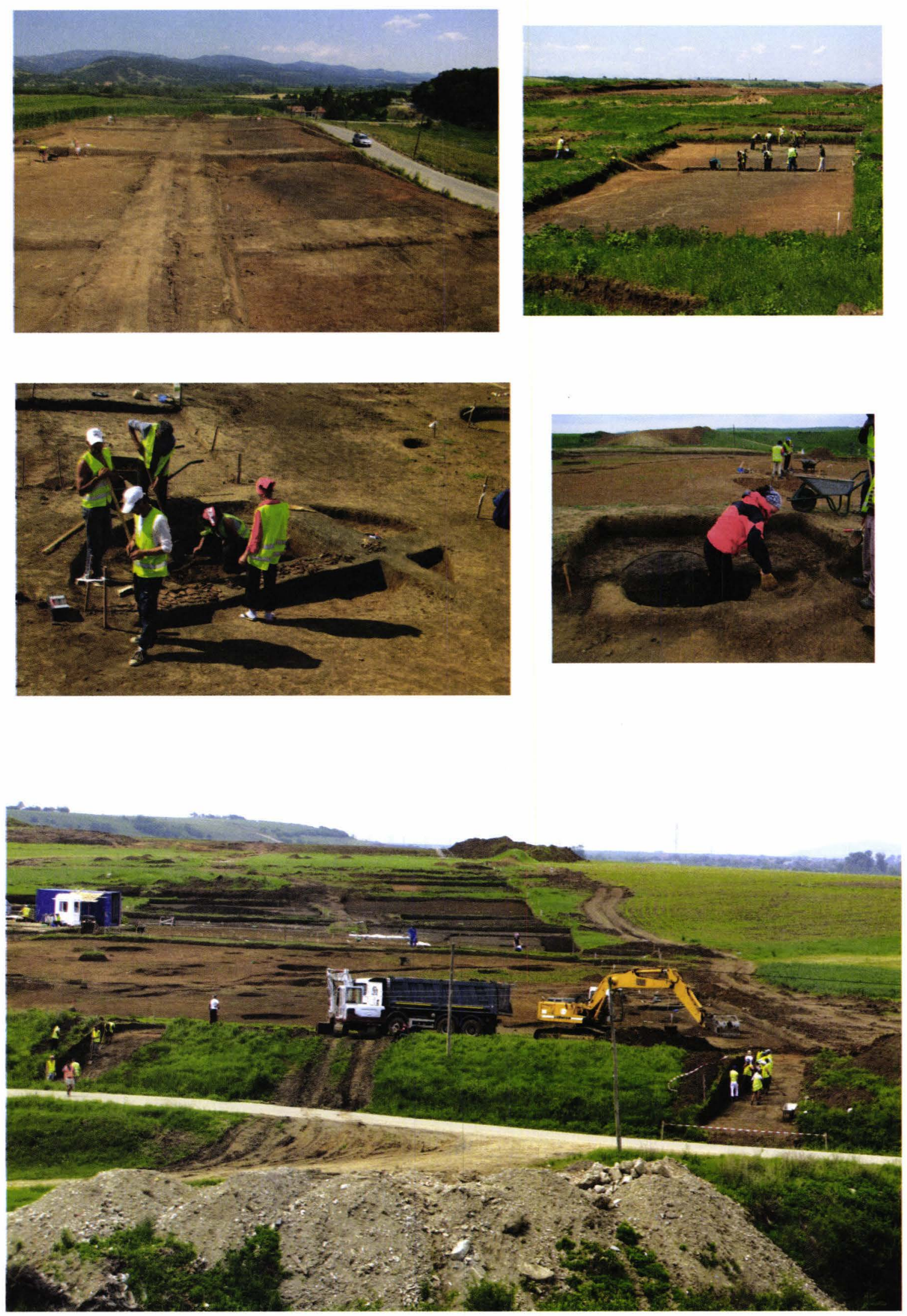

Imagini de ansamblu din timpul derulării cercetării arheologice preventive 

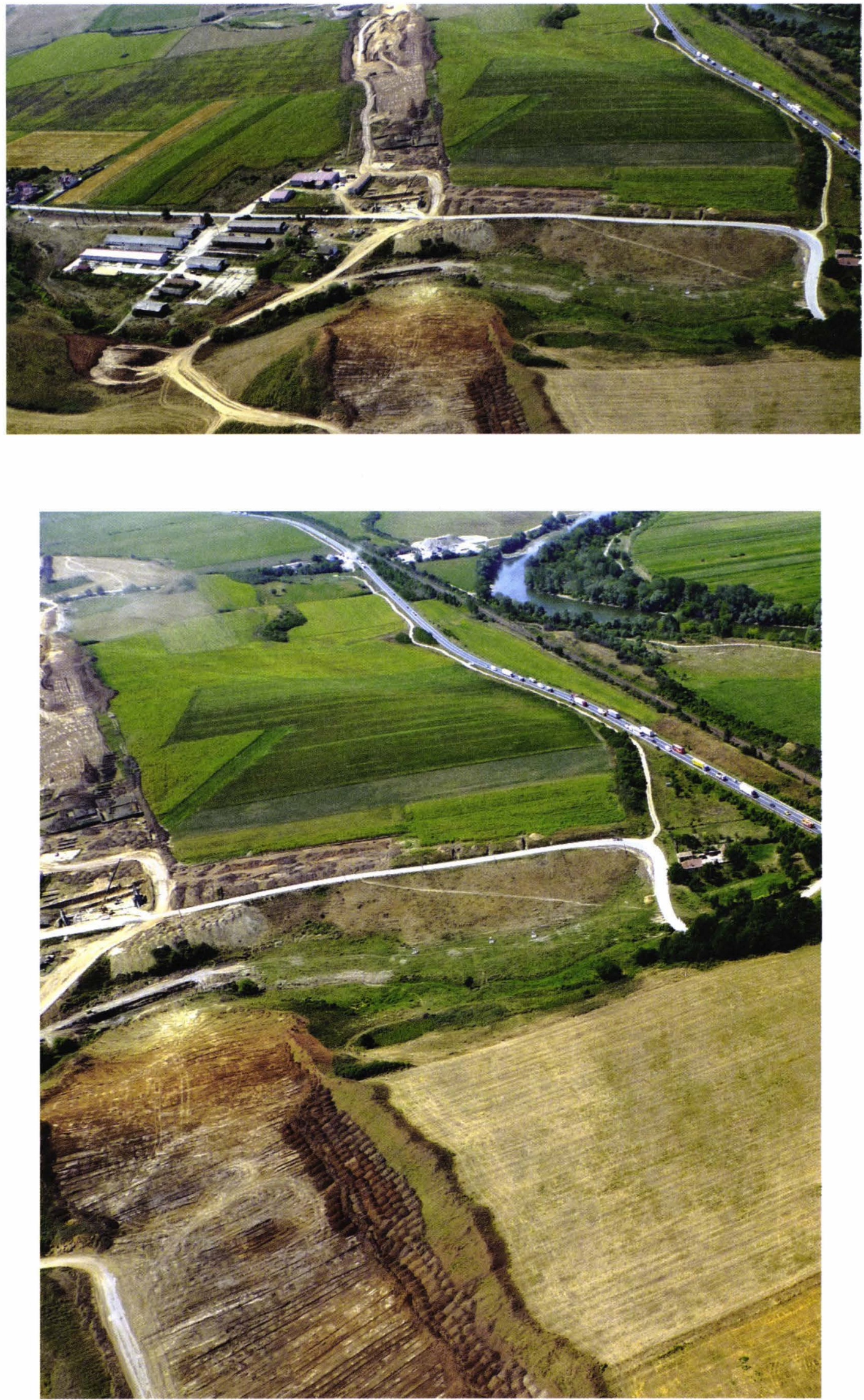

Imagini aeriene ale sitului la sfârşitul cercetărilor arheologice preventive (2012) 


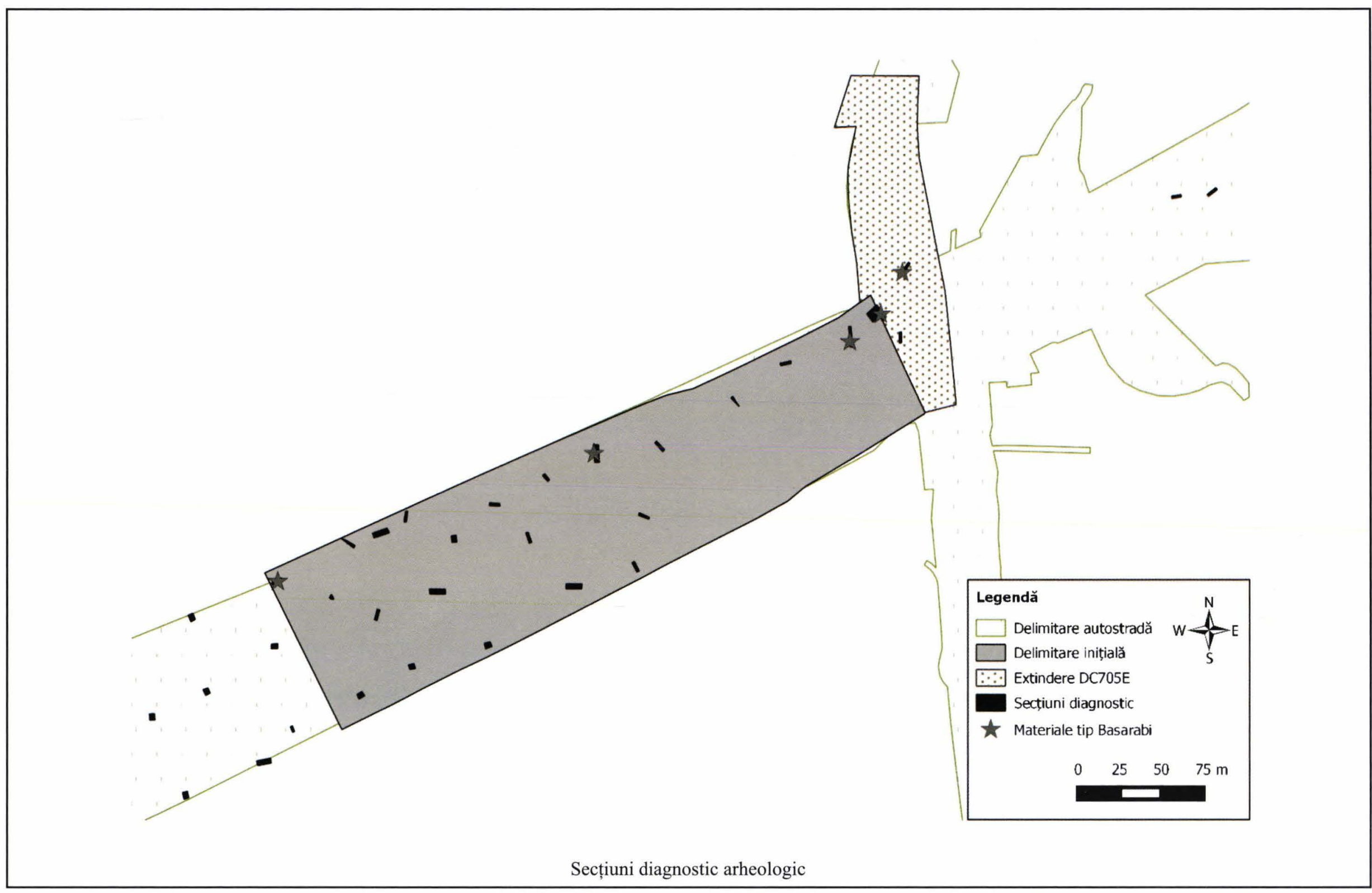

PI. VIII 


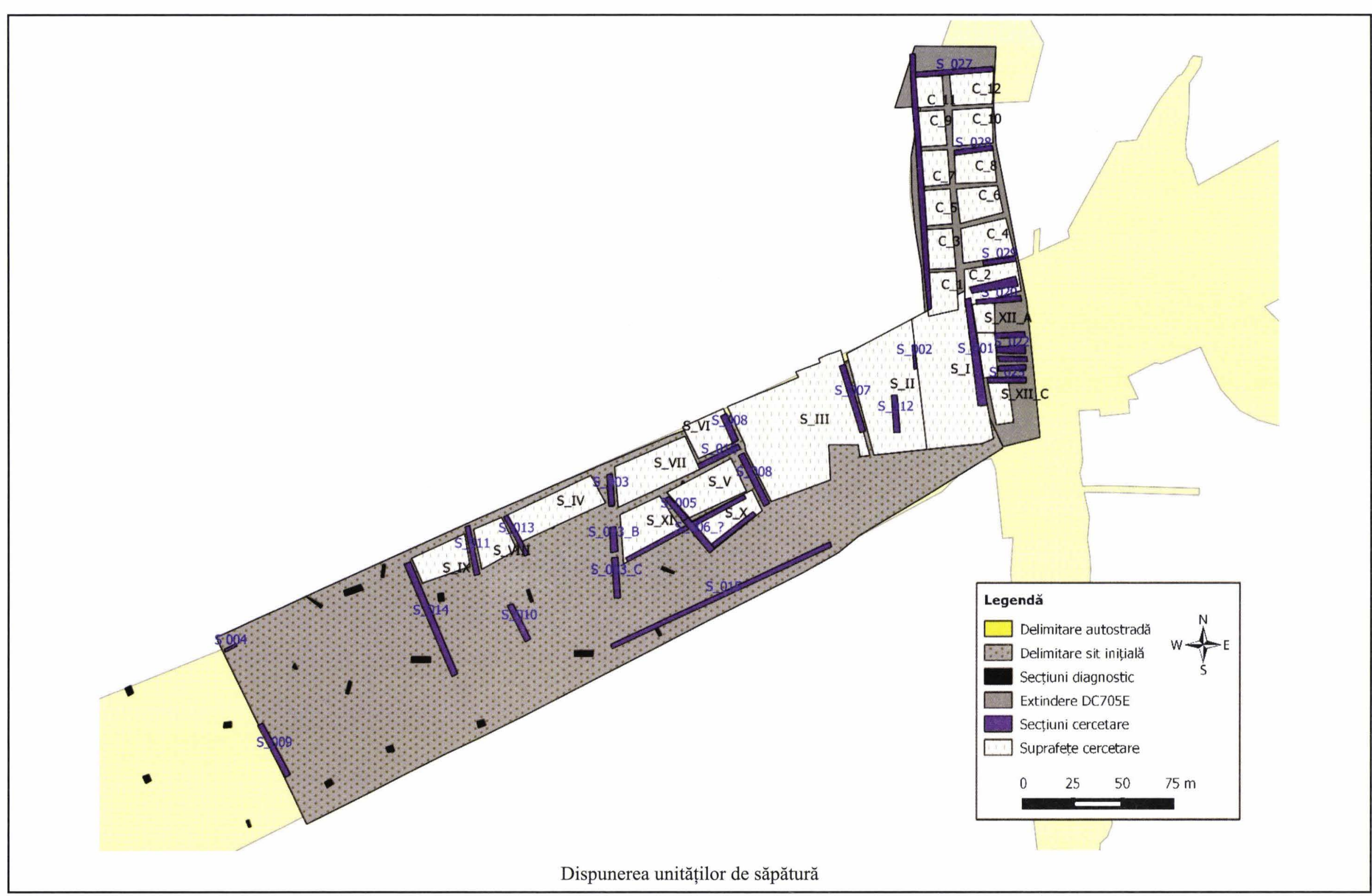

Pl. IX 


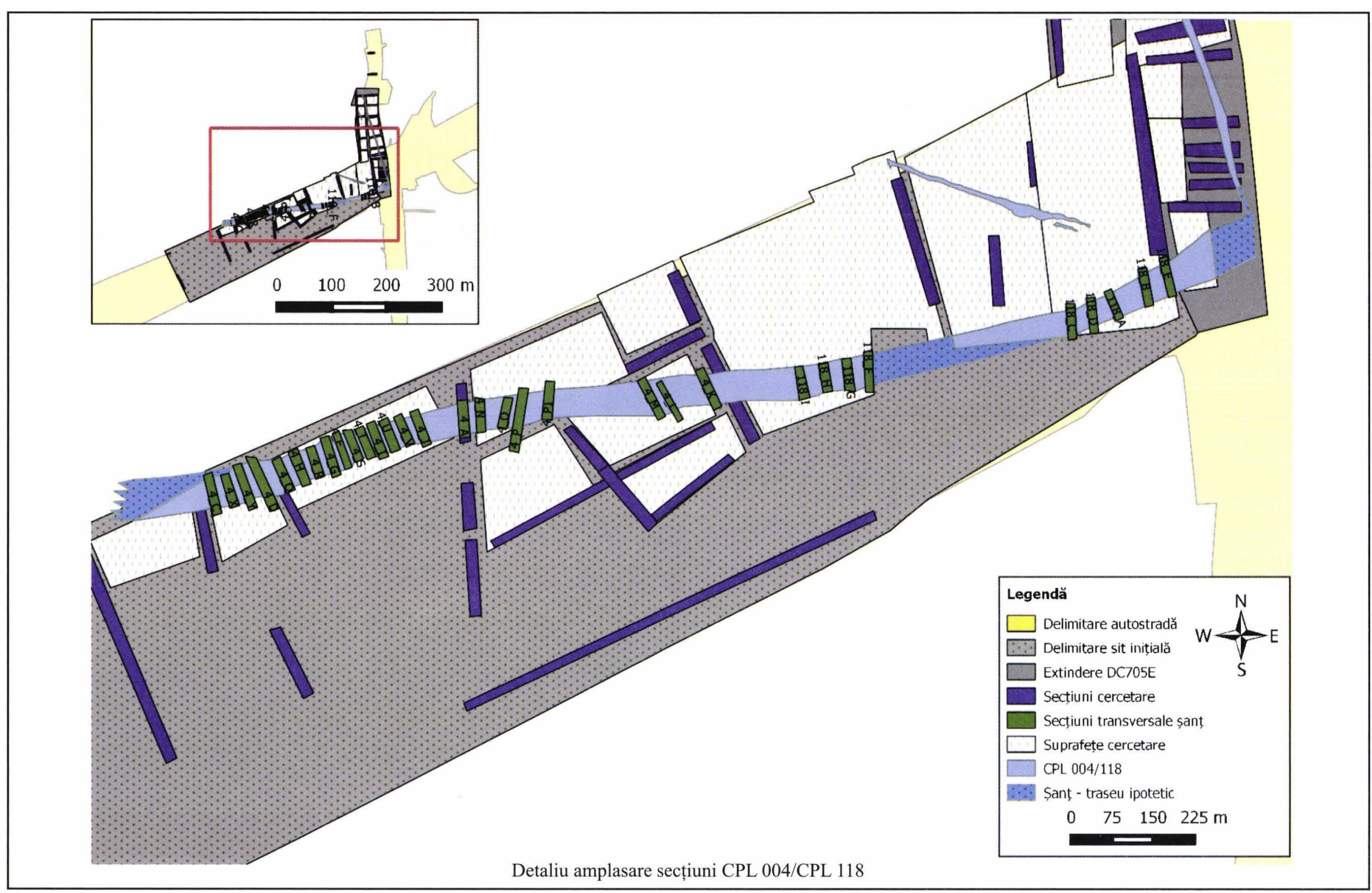

Pl. X 


\begin{tabular}{|l|}
\hline Legendă \\
$\square$ Delimitare autostradă \\
$\square$ Secțiuni cercetare \\
$\square$ Suprafețe cercetare \\
$\square$ complexe \\
a depozit Tărtăria I \\
$\Delta$ depozit Tărtăria II \\
$\star \quad$ Tezaur monetar \\
$\star$ Mormânt colectiv \\
Palisadă - traseu ipotetic \\
$\square$ Palisadă - traseu \\
$\square$ Șanț estic \\
$\square$ Șanț sudic \\
Șanț - traseu ipotetic
\end{tabular}
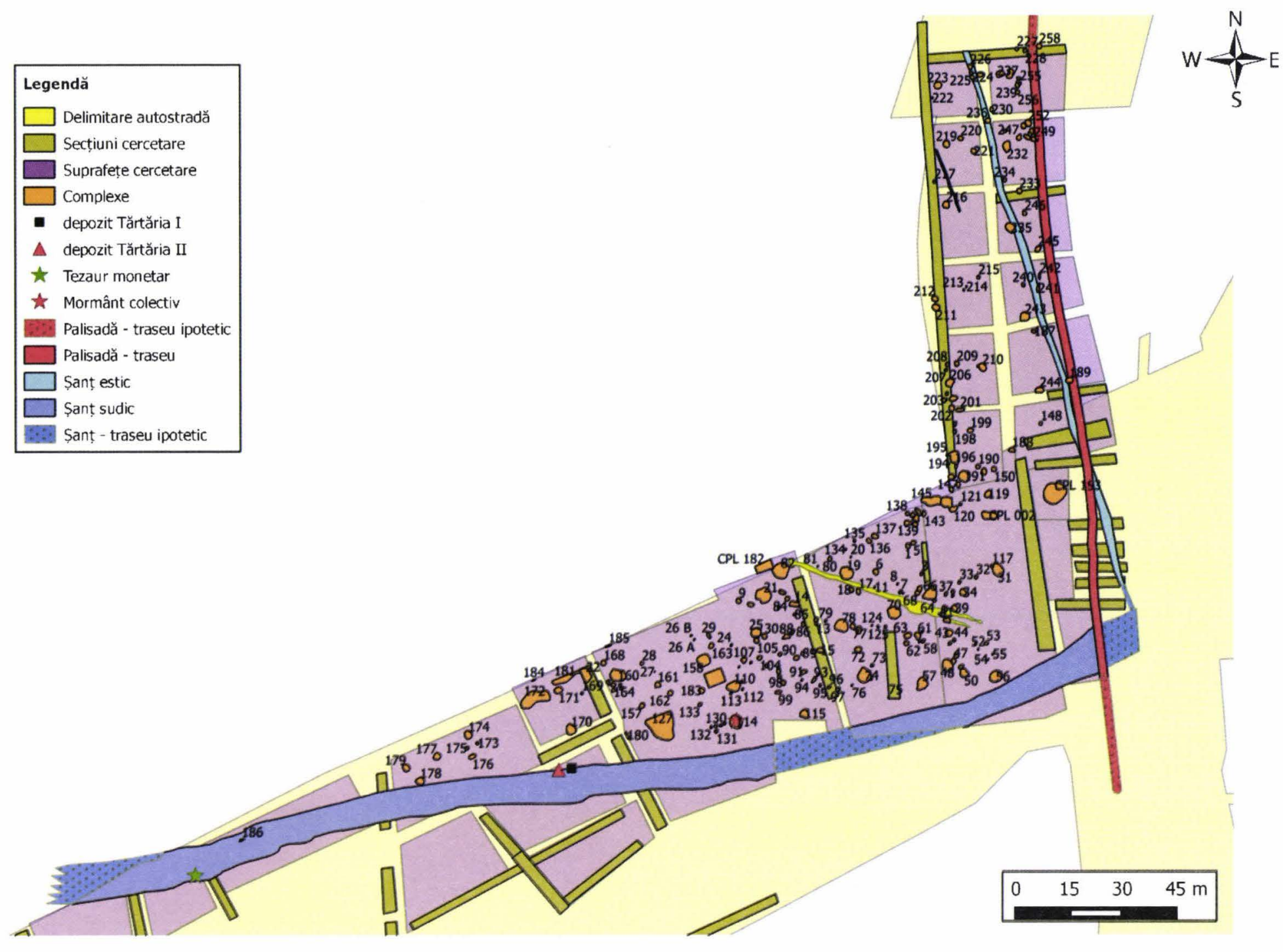

Dispunerea complexelor arheologice 


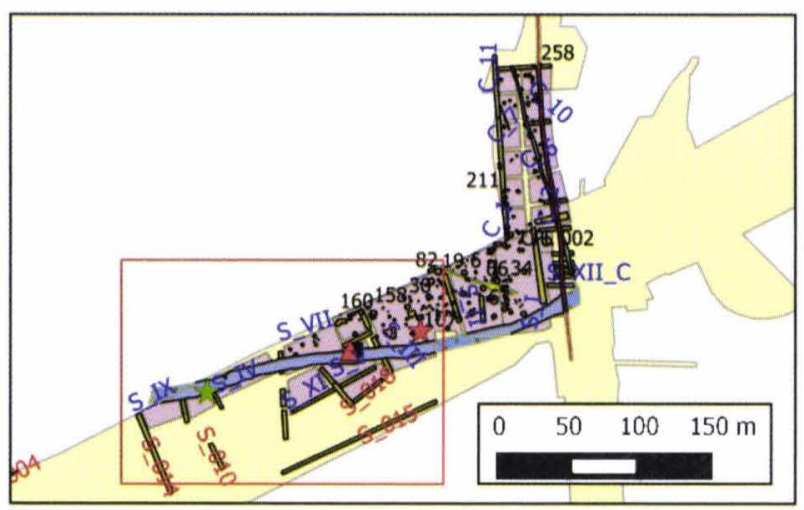

\begin{tabular}{|l}
\hline Legendă \\
$\square$ Delimitare autostradă \\
$\square$ Secțiuni cercetare \\
$\square$ Suprafețe cercetare \\
$\square$ Complexe \\
$\square$ depozit Tărtăria I \\
$\Delta$ depozit Tărtăria II \\
$\star$ Mormânt colectiv \\
$\star$ Tezaur monetar \\
$\square$ Sanț sudic \\
$\square$ Șanț - traseu ipotetic
\end{tabular}

$w \overbrace{S}^{N}$

depozit Tărtăria I

depozit Tărtăria

$\therefore$ Șant - traseu ipotetic

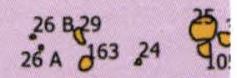

$18^{8}{ }_{109} d^{07 a c}$

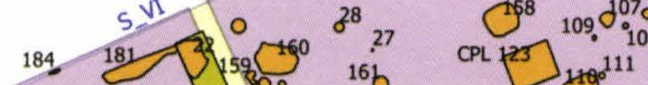

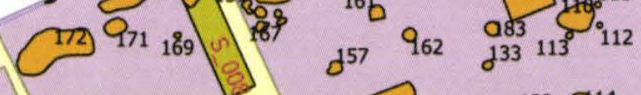

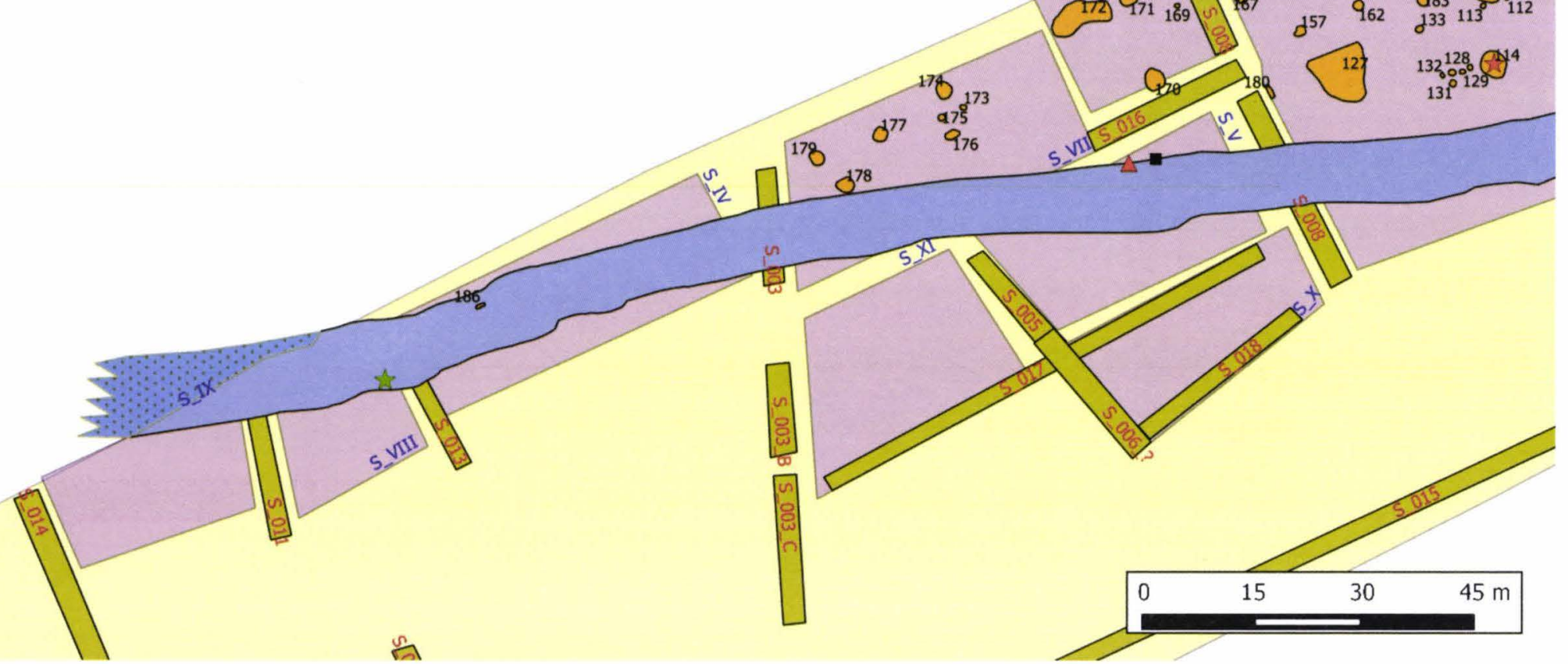

Dispunerea complexelor arheologice (detaliu zona de SV) 

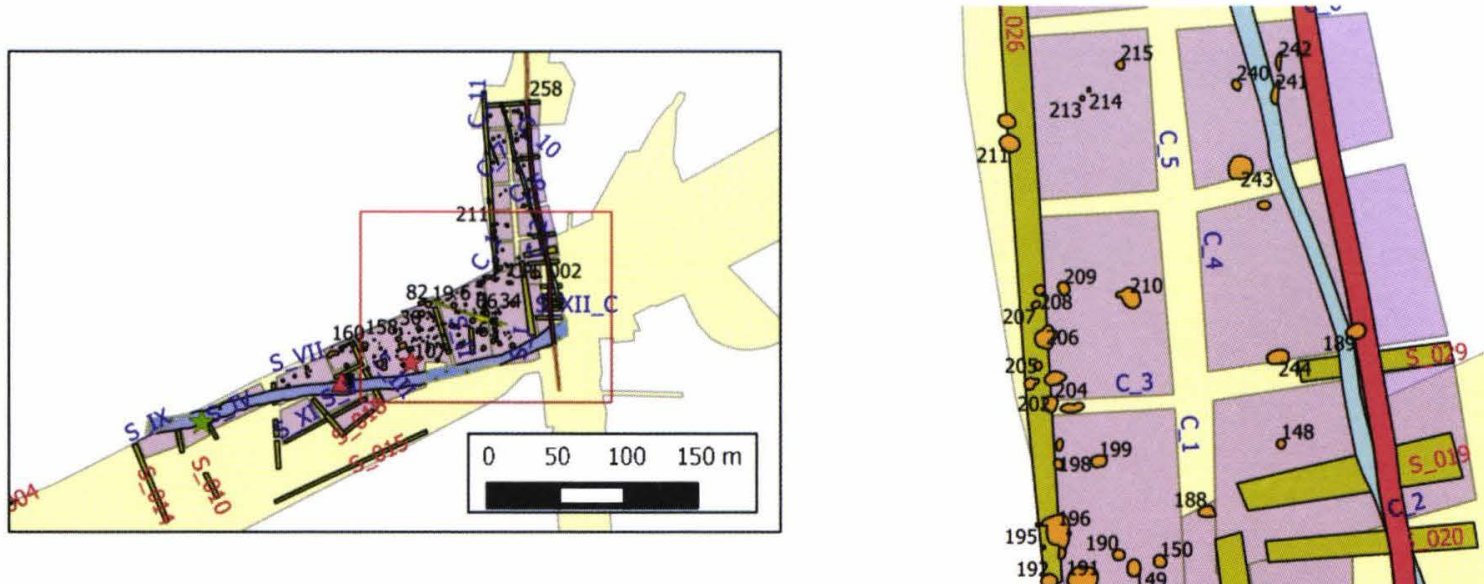

$w \overbrace{S}^{N}$

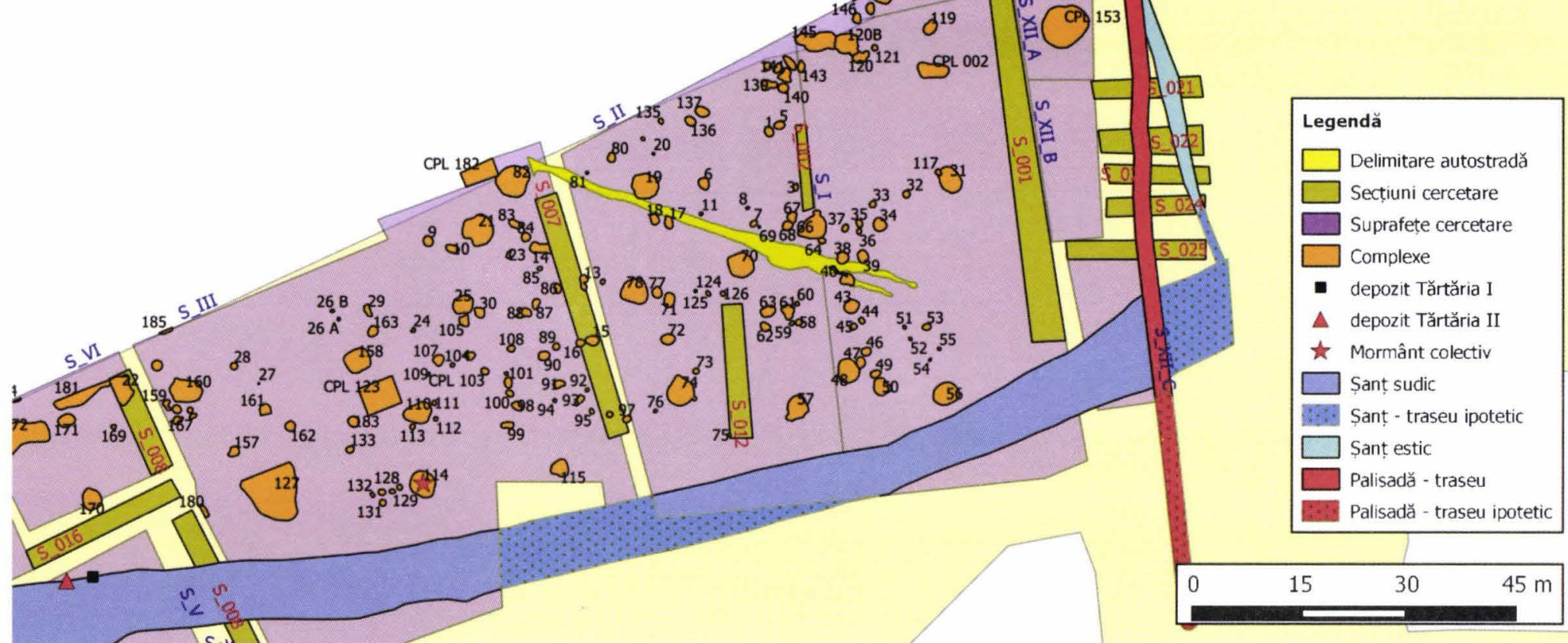

tritos

Dispunerea complexelor arheologice (detaliu zona de NE) 

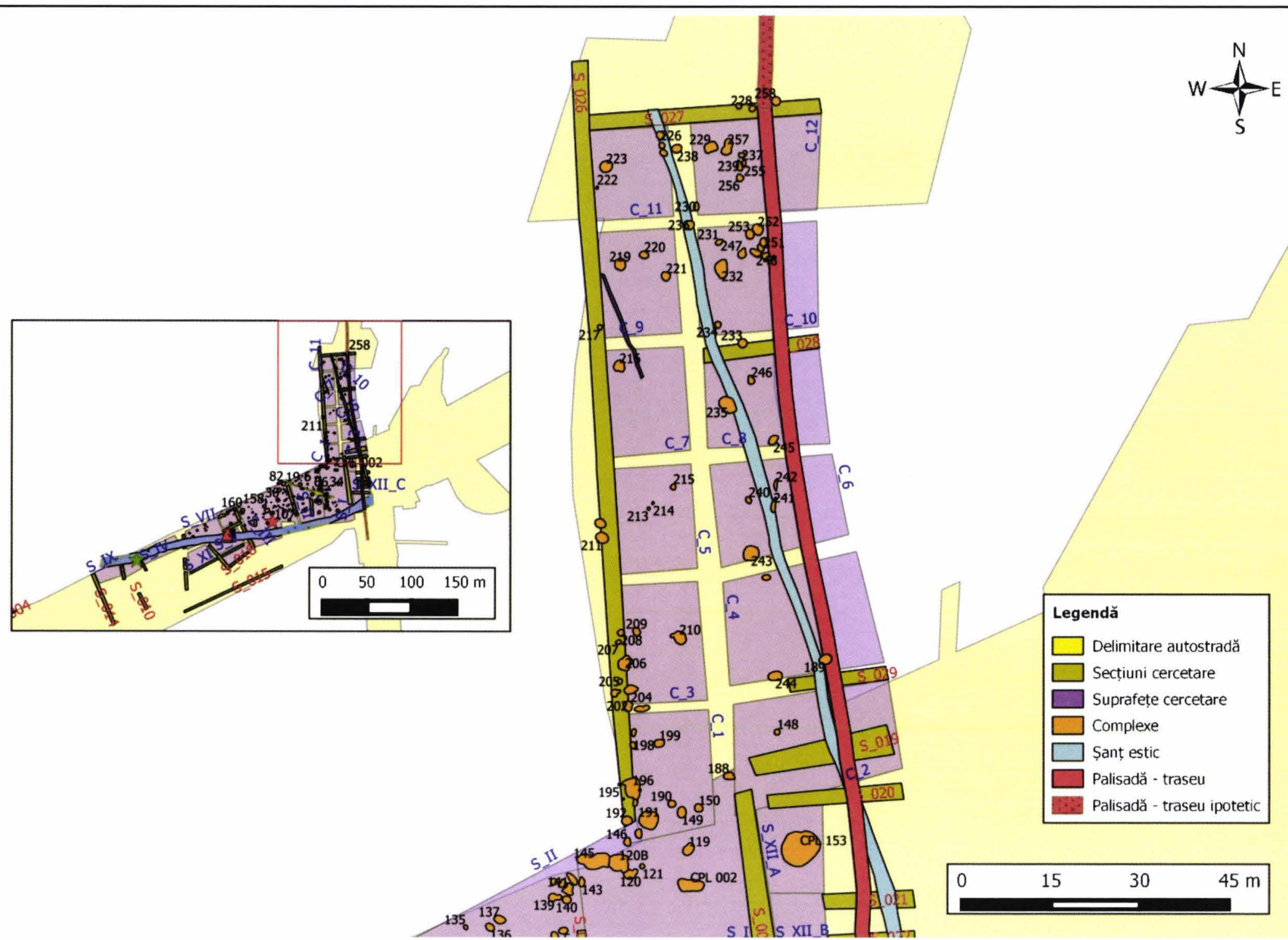

Dispunerea complexelor arheologice (detaliu zona de deviere a DC 705E) 


\begin{tabular}{|c|c|}
\hline \multicolumn{2}{|c|}{ Legendă } \\
\hline$\square$ & Delimitare autostradă \\
\hline 口 & Complexe \\
\hline - & depozit Tărtăria I \\
\hline$\Delta$ & depozit Tărtăria II \\
\hline$\star$ & Tezaur monetar \\
\hline$\Delta$ & Piese fier \\
\hline $\mathbf{A}$ & Piese bronz \\
\hline$\triangle$ & Chirpici \\
\hline & Vase întregibile \\
\hline - & Piese lut \\
\hline 뭄 & Piatră prelucrată \\
\hline$\star$ & Mormânt colectiv \\
\hline$\stackrel{\Delta}{\Delta}$ & Fragmente schelete umane \\
\hline 0 & Oase prelucrate \\
\hline$\square$ & Oase de animal \\
\hline & Palisadă - traseu \\
\hline$B:$ & Palisadă - traseu ipotetic \\
\hline$\square$ & Sant sudic \\
\hline$\square$ & Șant estic \\
\hline$\therefore \therefore$ & Șant - traseu ipotetic \\
\hline
\end{tabular}

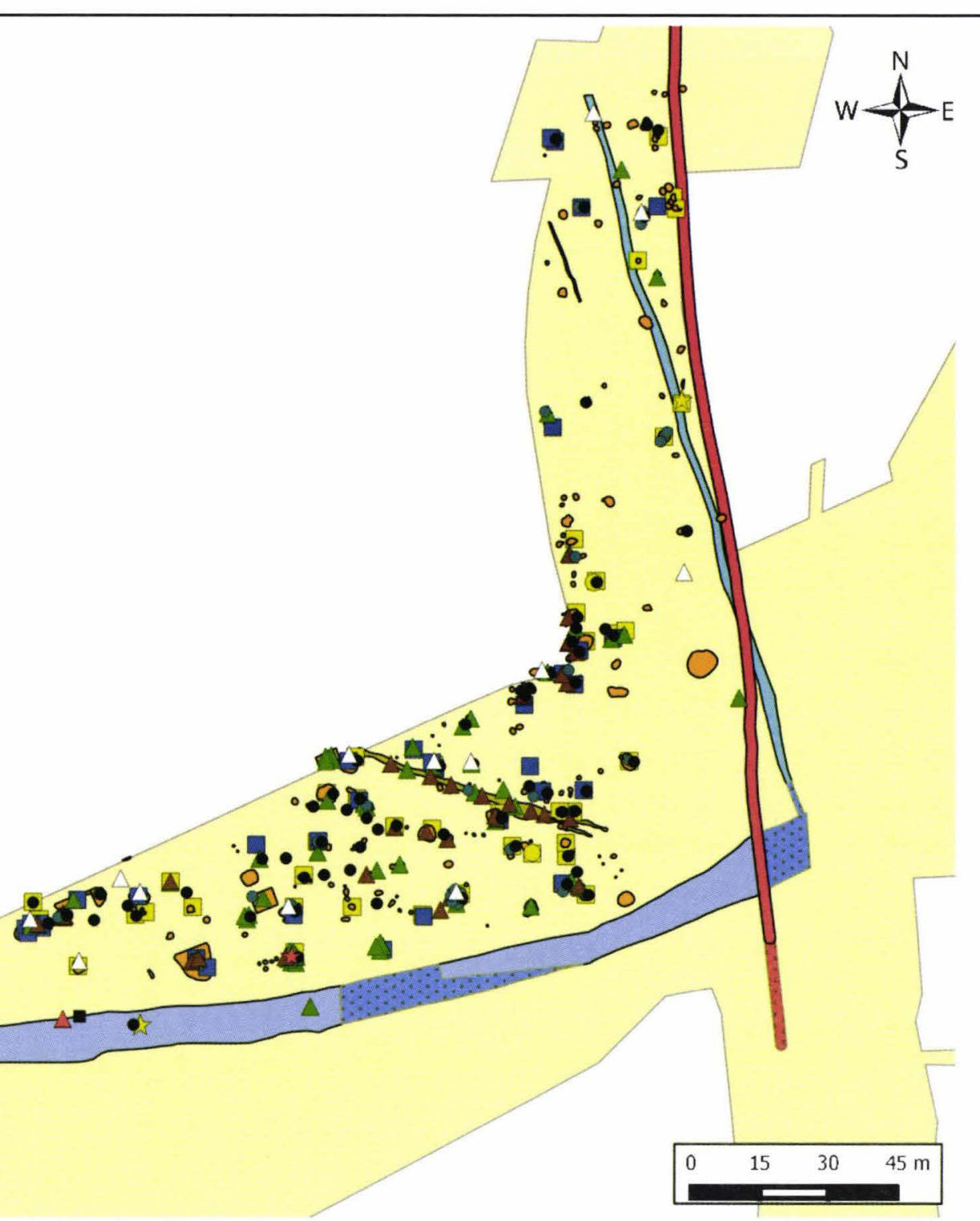

Dispunerea materialului arheologic special 


\begin{tabular}{|l|}
\hline Legendă \\
$\square$ Delimitare autostradă \\
$\square$ Complexe \\
$\Delta \quad$ depozit Tărtăria I \\
$\star \quad$ Tezaur montăria II \\
$\Delta \quad$ Piese fier \\
$\Delta \quad$ Piese bronz \\
$\triangle$ Chirpici \\
- Vase întregibile \\
$-\quad$ Piese lut \\
Piatră prelucrată \\
$\star \quad$ Mormânt colectiv \\
$\star$ Fragmente schelete umane \\
Oase prelucrate \\
$\square$ Oase de animal \\
$\square$ Șanț sudic \\
Sanț - traseu ipotetic
\end{tabular}

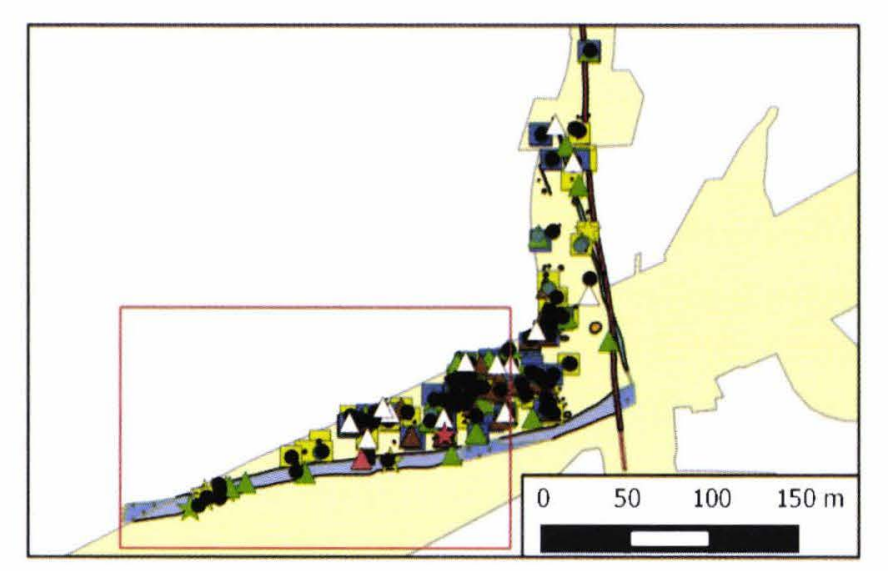

粗

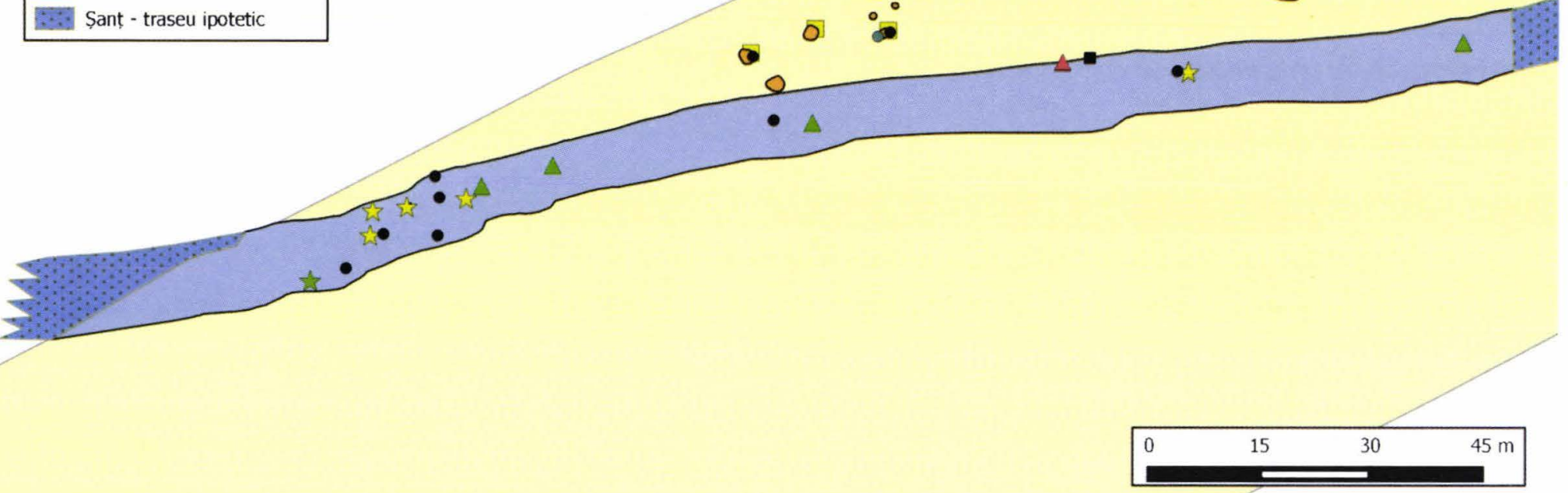

Dispunerea materialului arheologic special (detaliu zona de SV) 


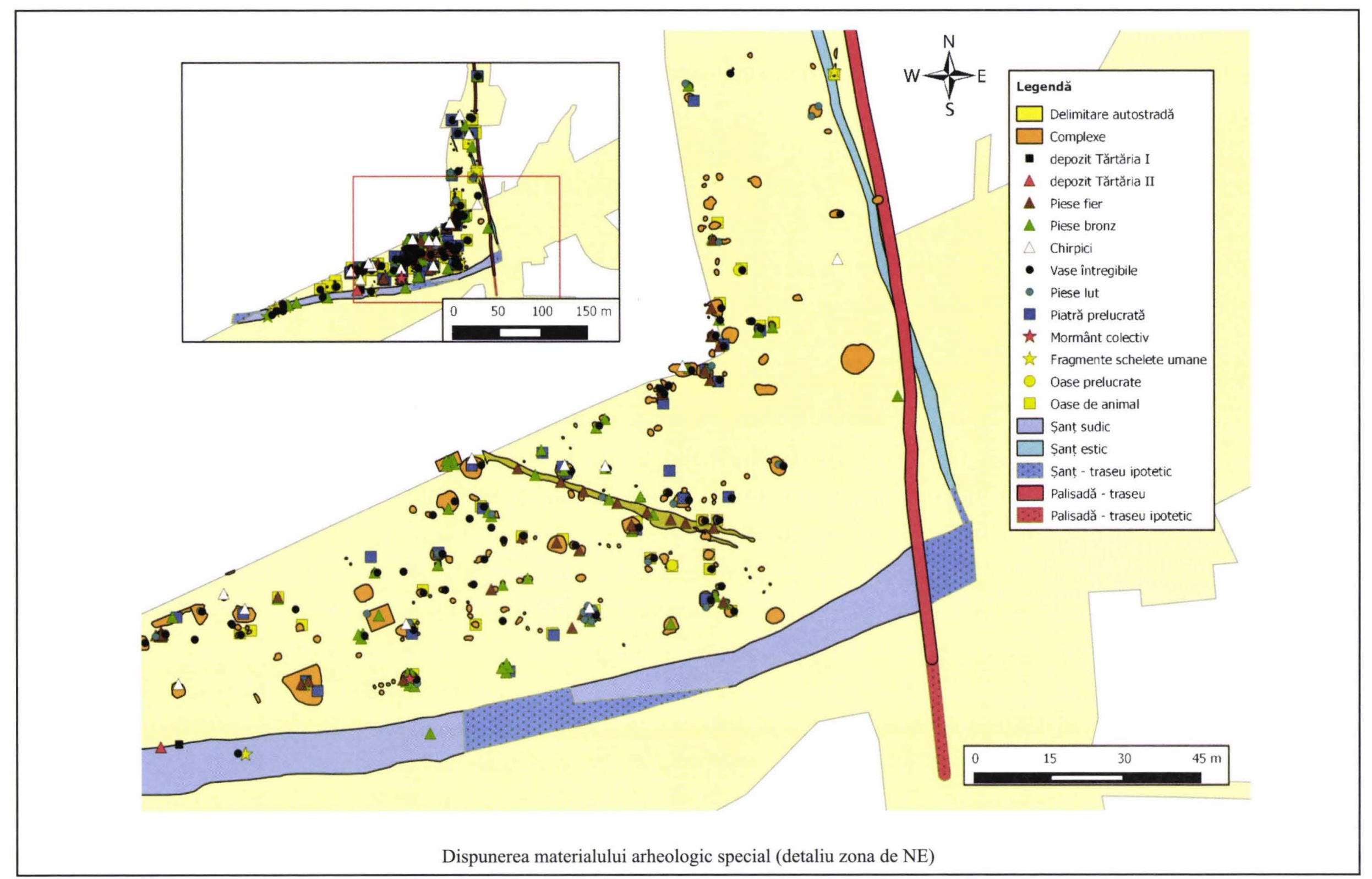

PI. XVII 


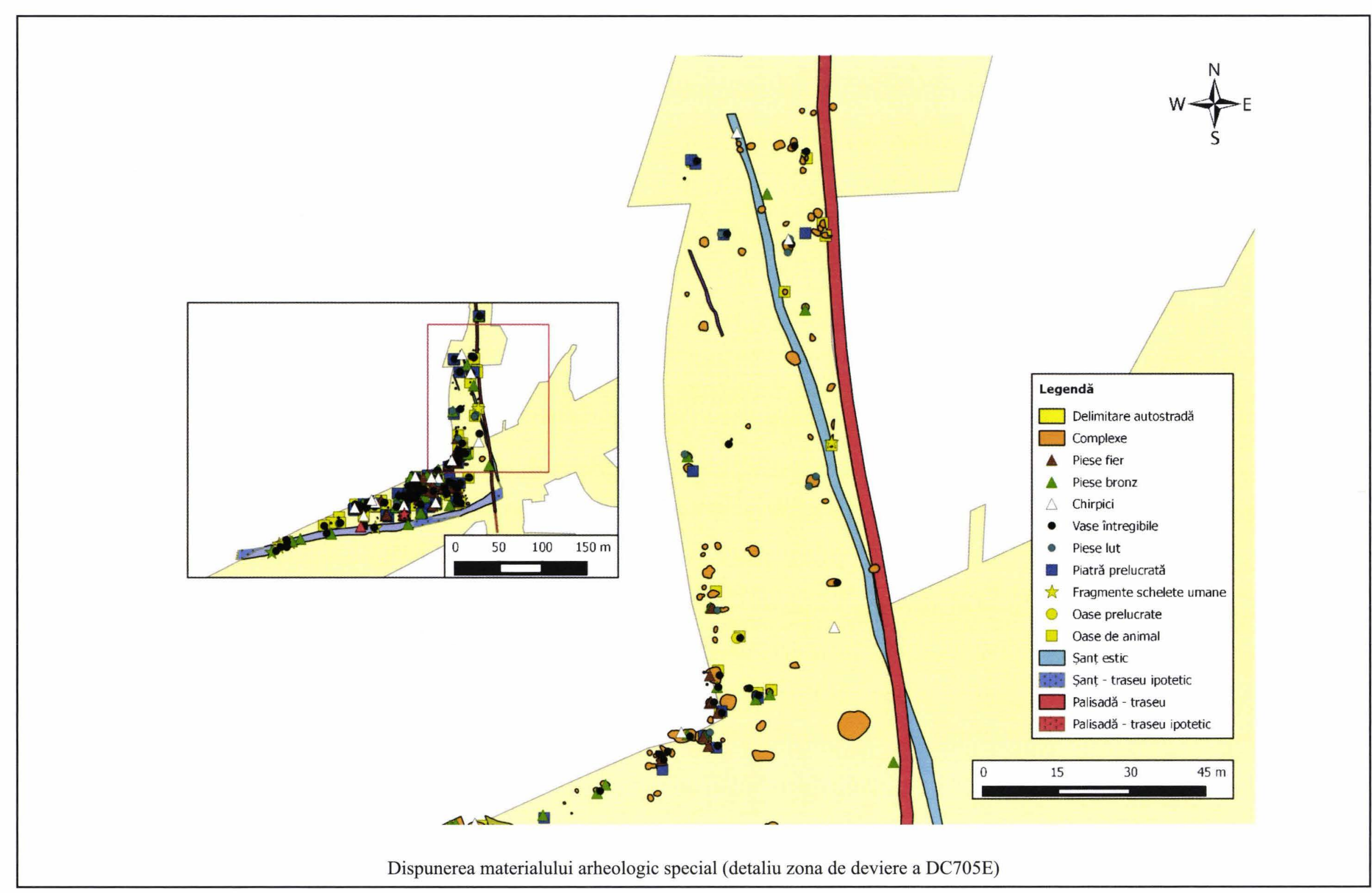




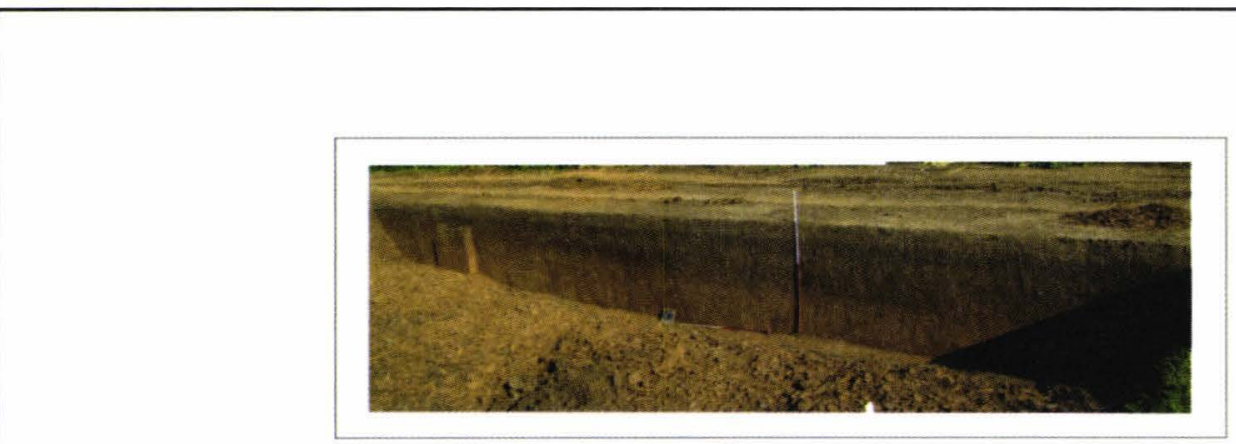

1.
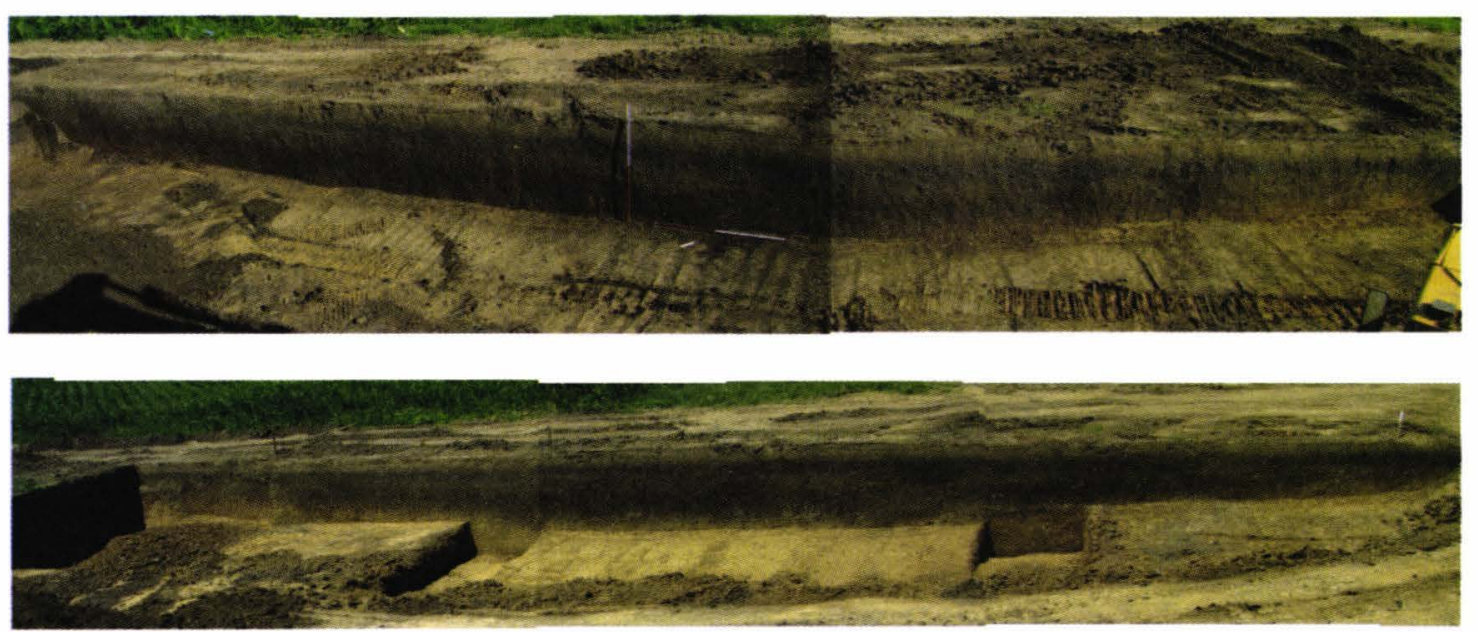

2.

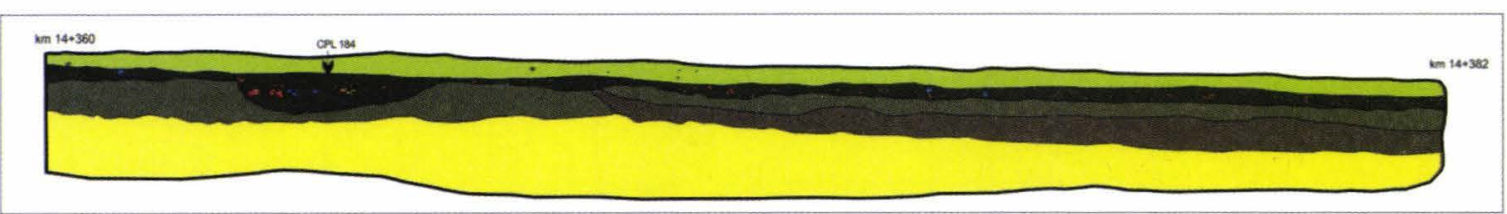

3.
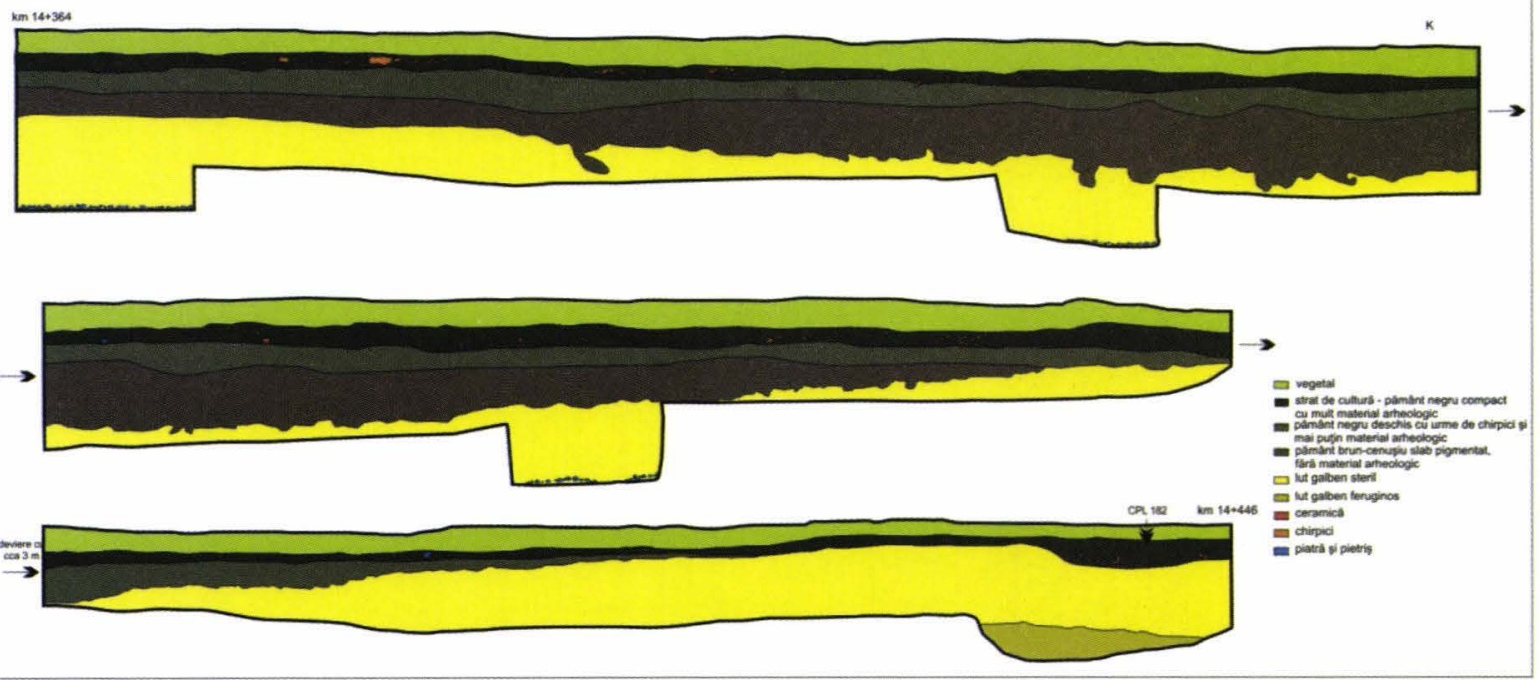

4.

Profile magistrale de N. Fotografii: 1. S VI; 2. S III (doua stadii de cercetare); desene: 3. S VI; 4. S III 


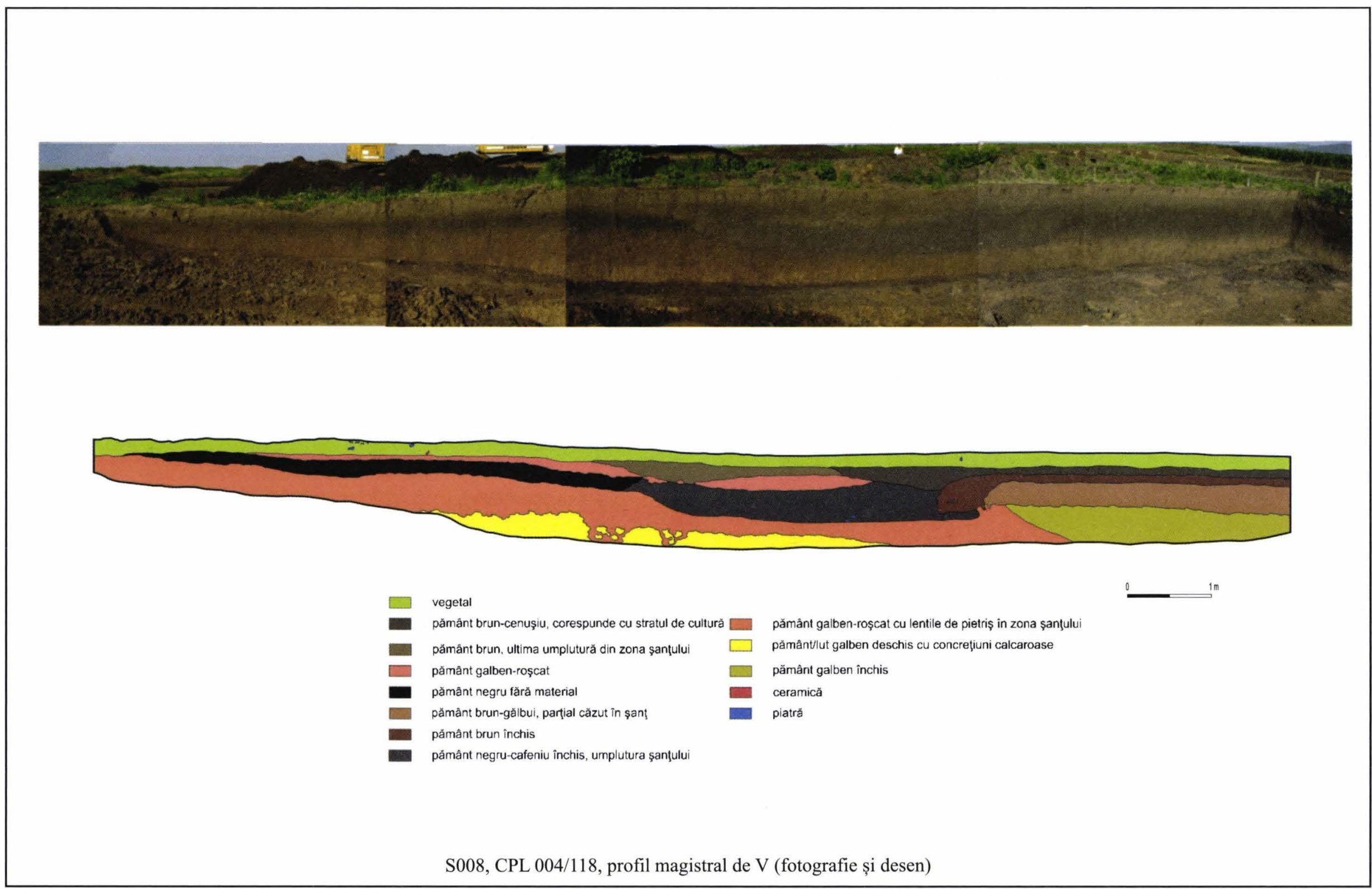

\section{Pl. XX}




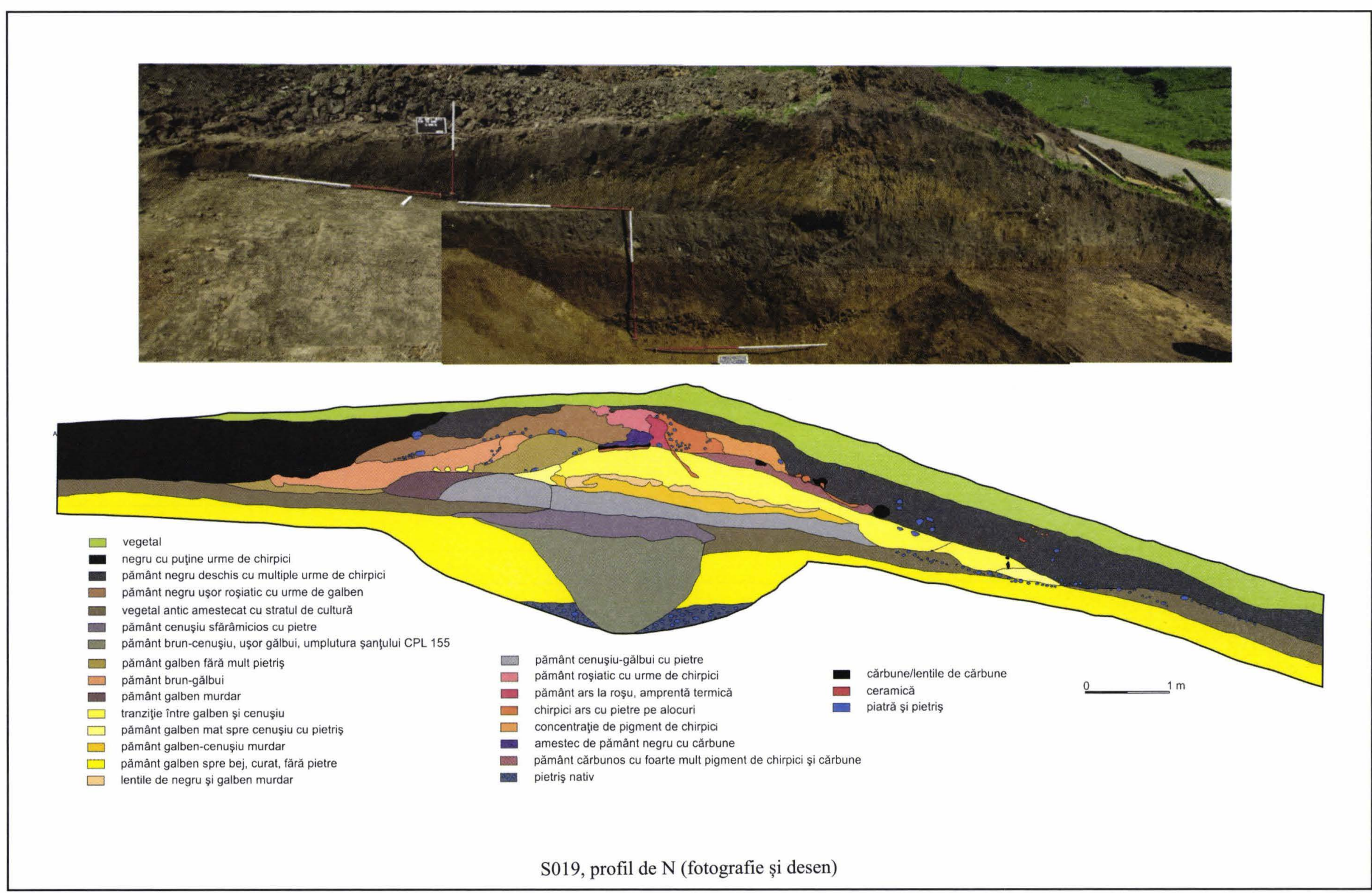

PI. XXI 


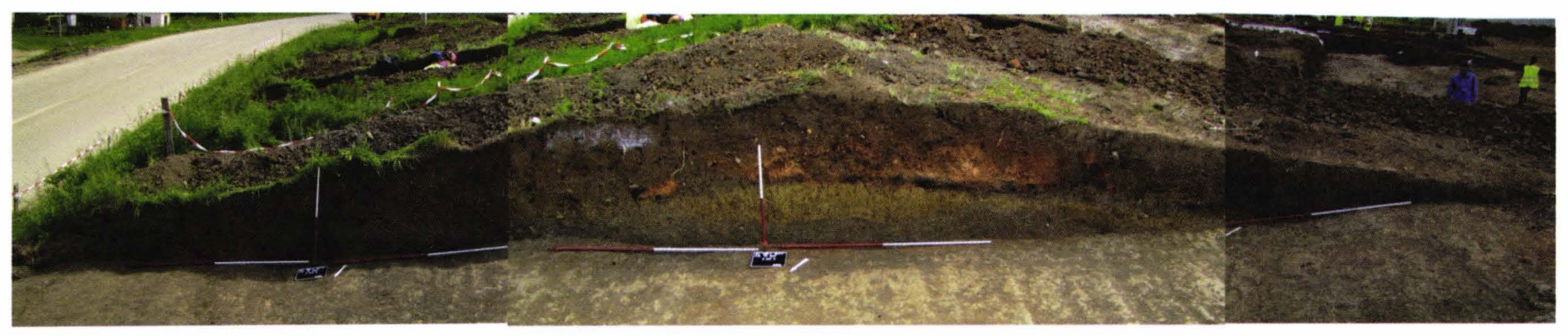

\section{- strat dr cultură, negru-cenuşiu cu pigmenți vagi de chirpici - pămån '́negru cu urme de chirpici \\ - pămảnt cenuş̧iu lutos, vag pigmentat cu chirpic \\ pảmânt cenuşiu închis amestecat cu cảrbune \\ - umplutura şanţului CPL 155, pământ brun-cenuşiu, uşor gălbui \\ $\square$ galben steri \\ - pietriş nativ}

cărbune, pământ cărbunos, urme de bảrne arde din lemn

strat de chirpici ars stărảmicios

gropi de stâlpi umplute cu pământ cenuşiu-roşiatic închis, cu urme de chirpici pe alocuri

pảmânt roşu-cenuşiu, amprentă termică

- pământ negricios cu foarte mult chirpic/ rest de palisadá

pământ brun-negricios cu urme de chirpici

lentiă de pămånt cenuşiu inchis

pământ galben lutos

lentilă galben-cenușie

pảmâni cenuş̧iu des

cu galben şi chirpici

- vegetal
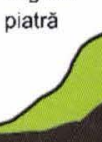

chis, ameste
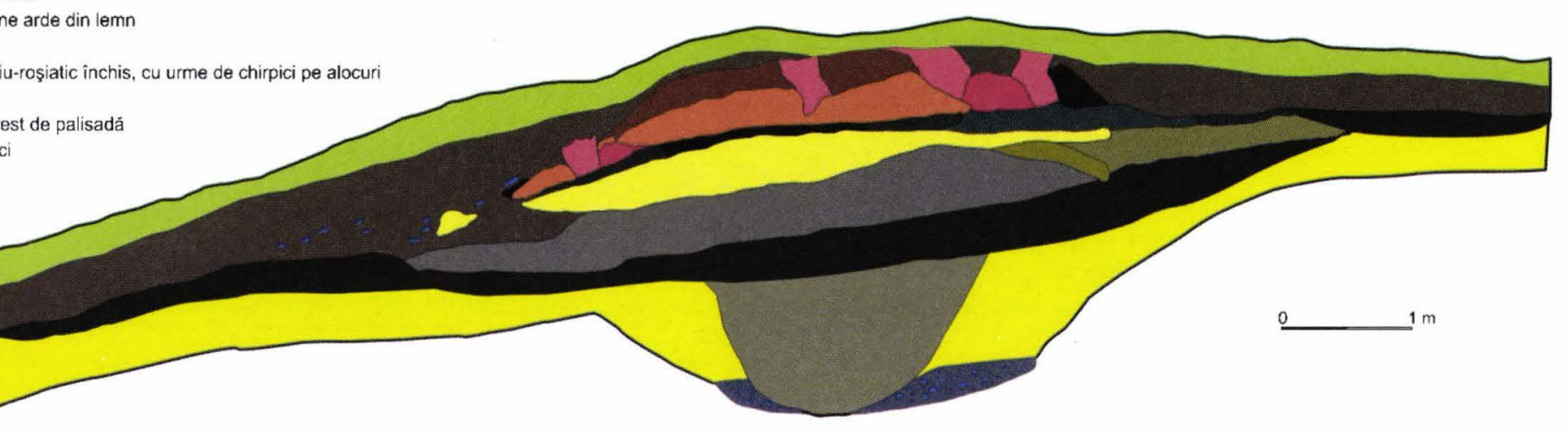

S019, profil de S (fotografie și desen) 


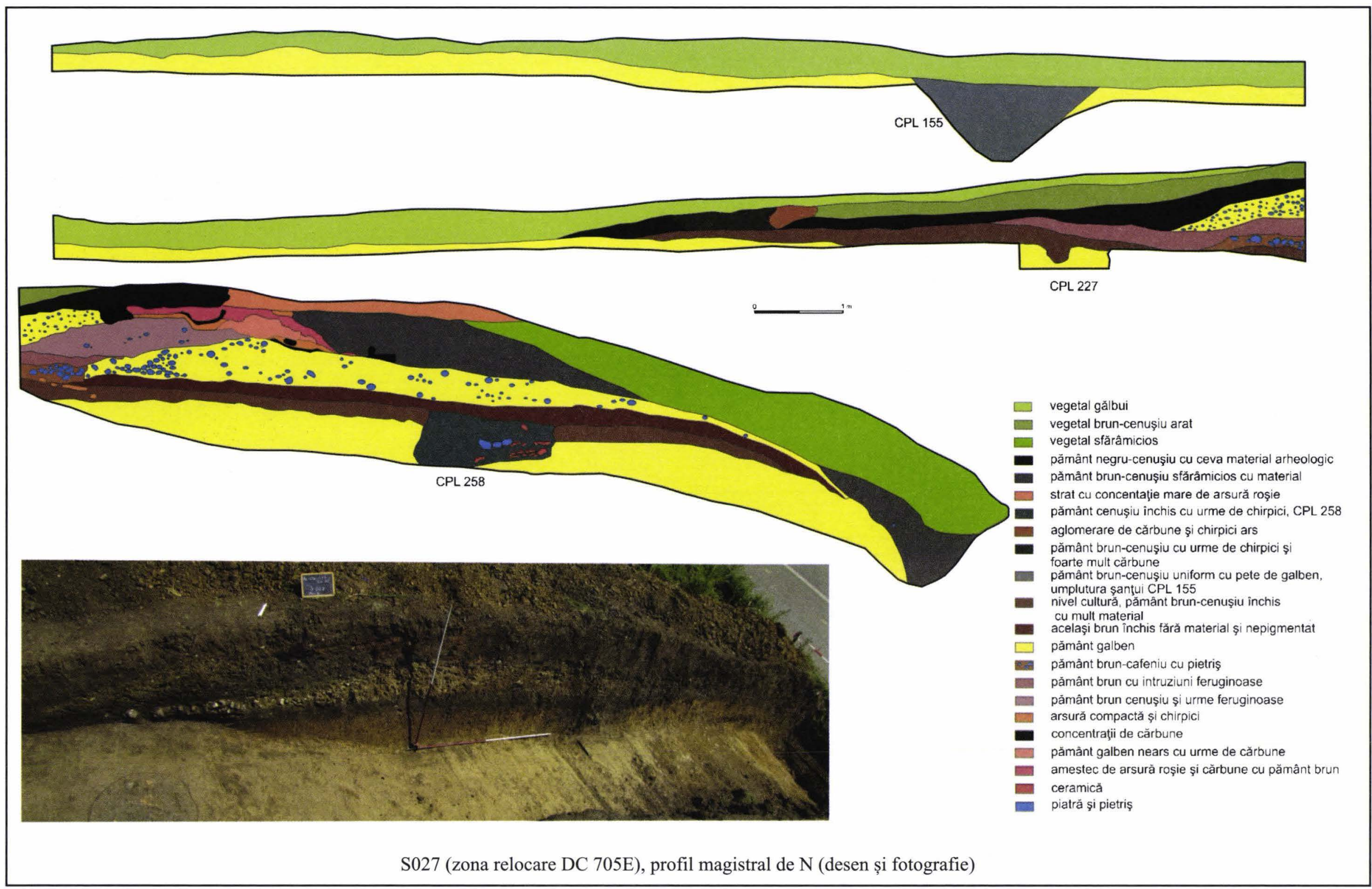

PI. XXIII 


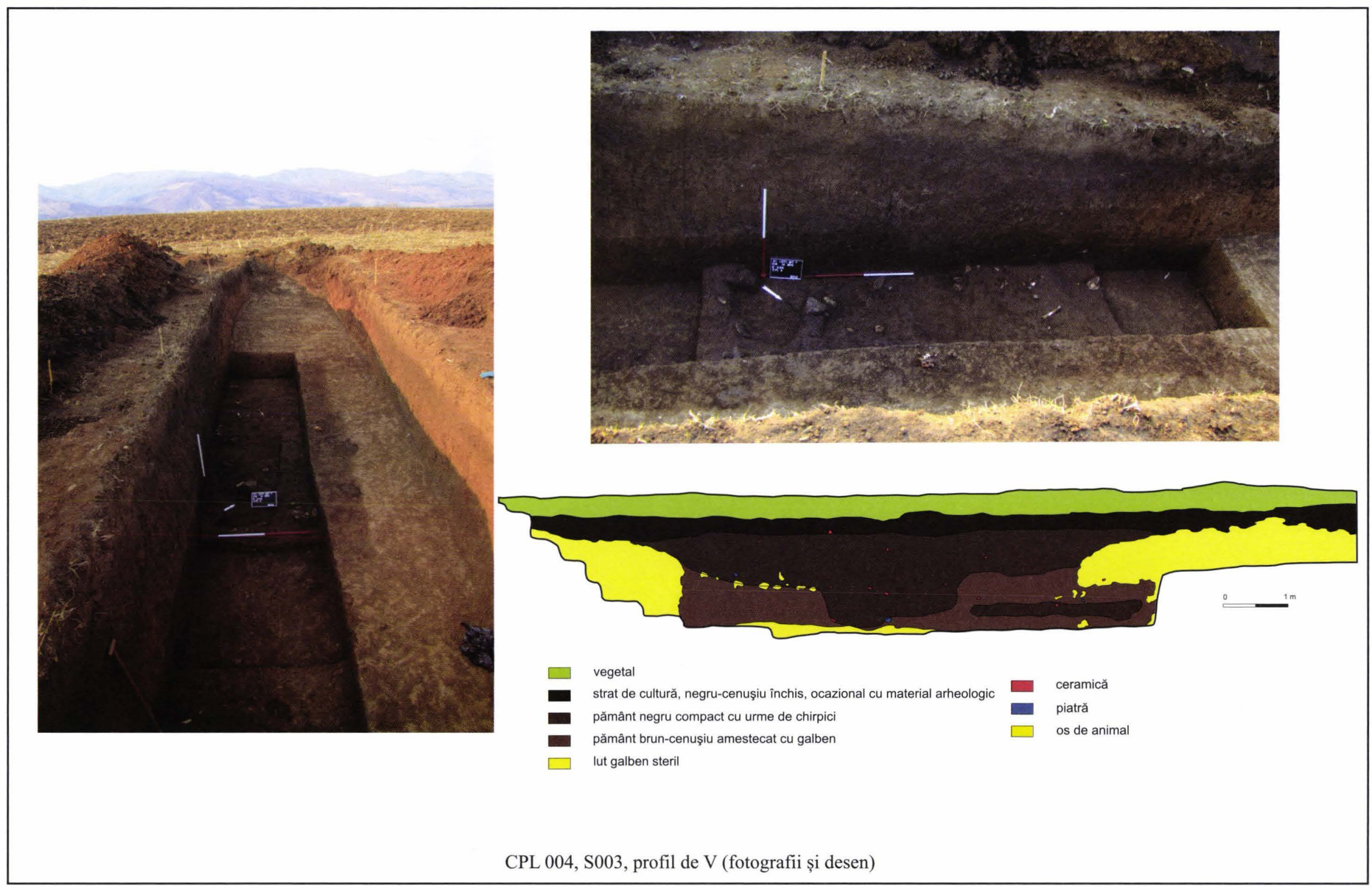

PI. XXIV 

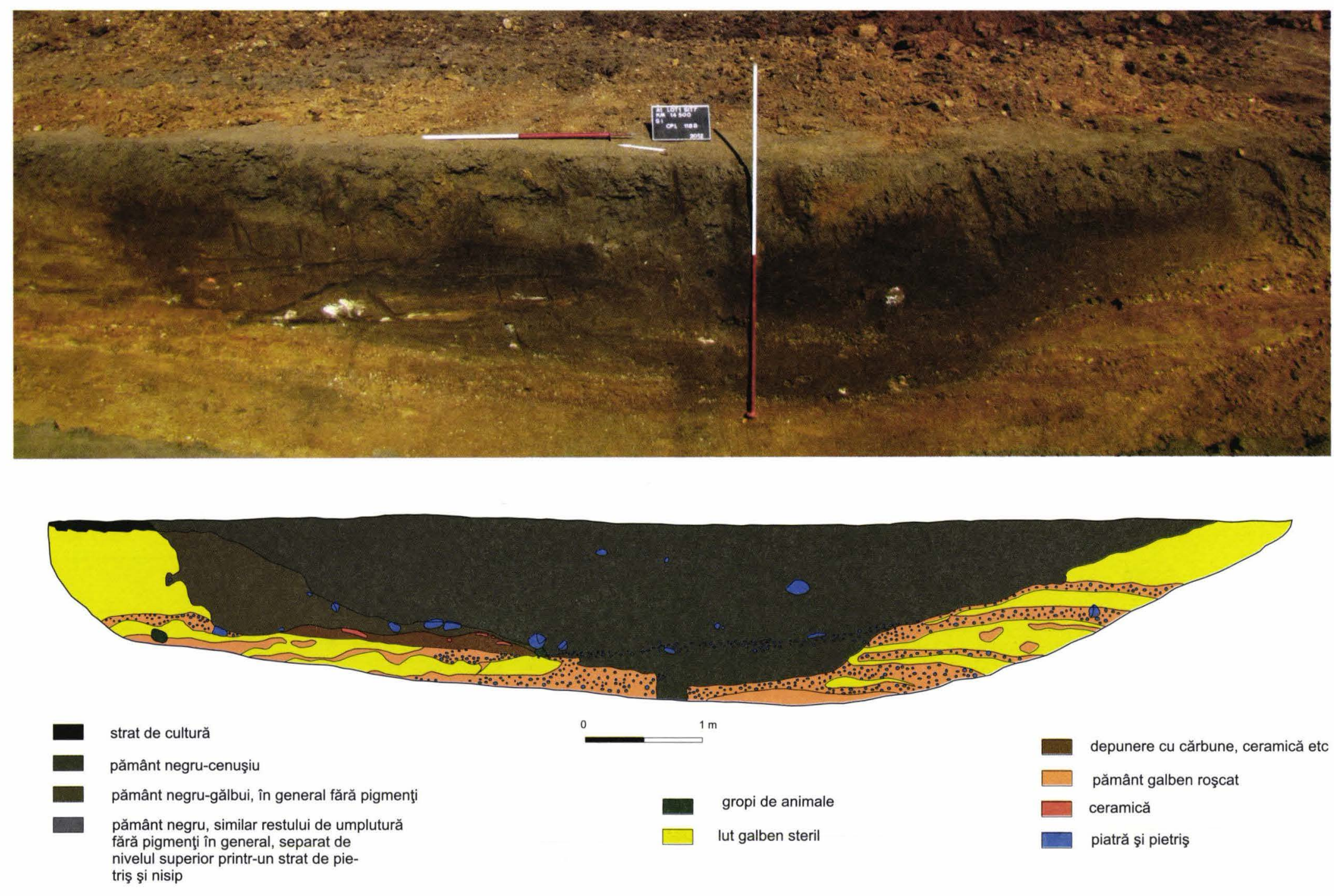

CPL 118 B, profil de V (fotografie și desen) 

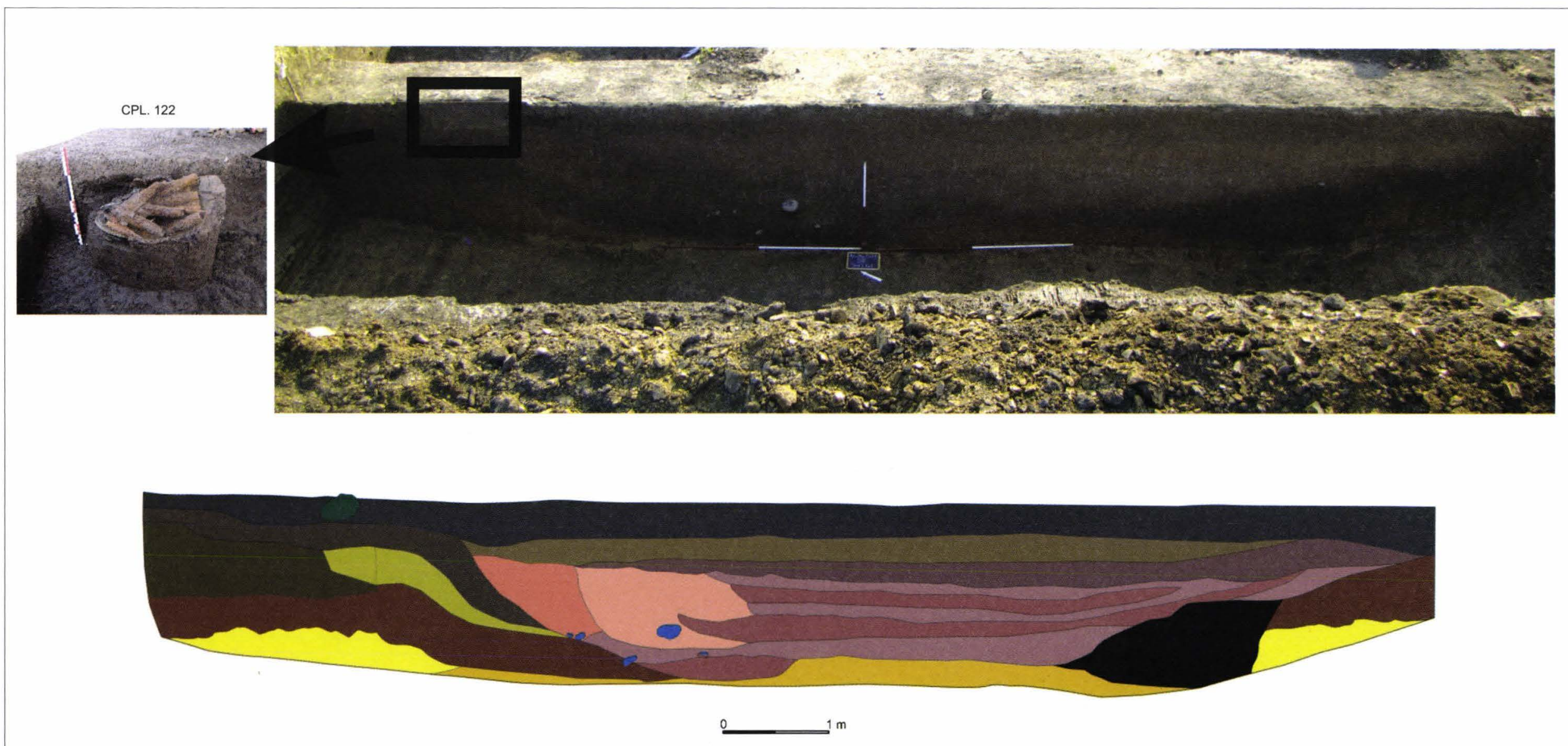

pământ negru-cenuşiu, strat de cultură

- pământ cenușiu-gălbui

- pământ cenuşiu închis

pământ galben nativ

pământ galben feruginos

zona de tranzitie intre cenuşiu și galben

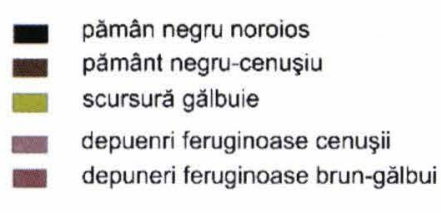

- depuneri feruginoase concentrate cu aspect roşcat-oran

- depuneri brun-gălbui slab feruginoase

depuneri feruginoase cu nuante amestecate

- cafeniu gălbui neferuginos

- diferite nuanţe de cafeniu şi cenuşiu

- depozit de bronzuri

- piatră

S V, CPL 004 M/118 și CPL 122 (depozit Tărtăria II), profil de E (fotografie și desen)

PI. XXVI 

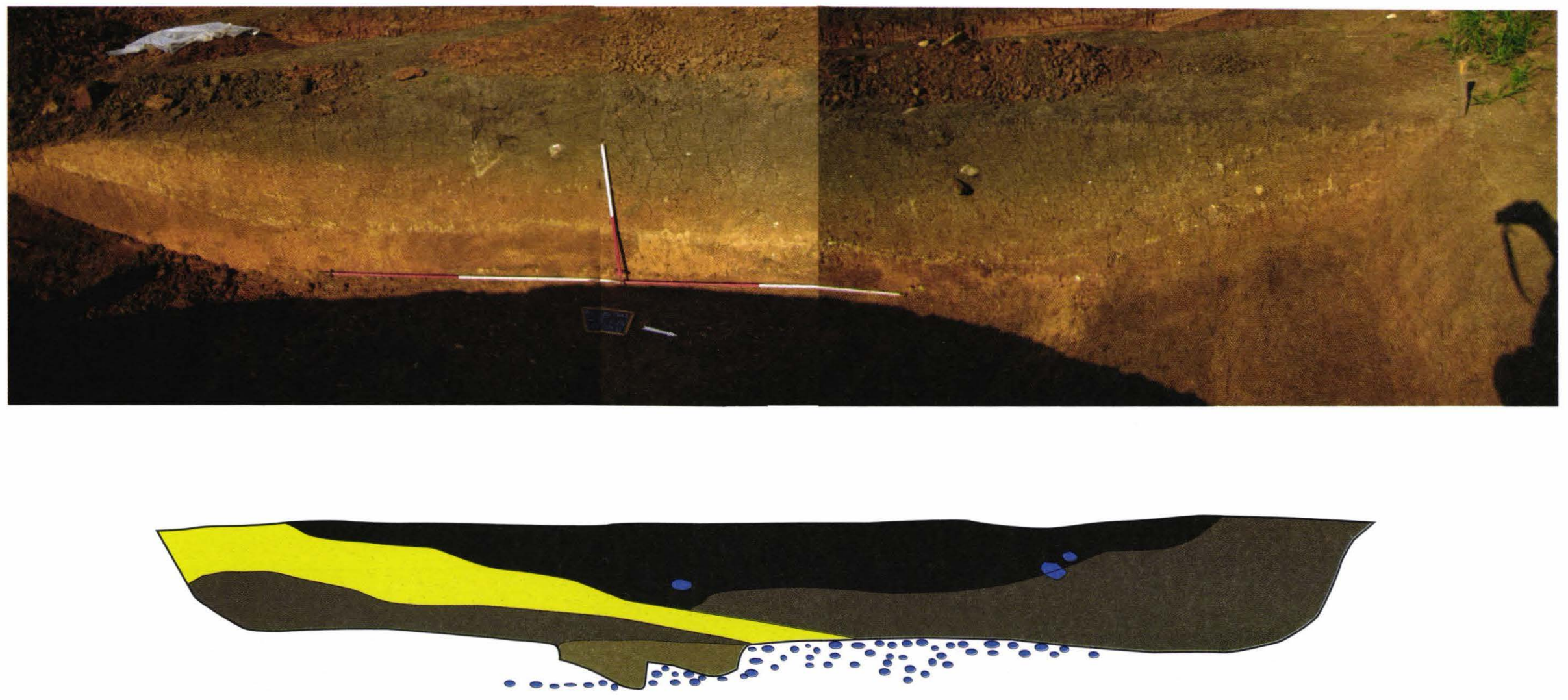

pământ negru-cenuşiuuşor pigmentat 0 $1 \mathrm{~m}$

lut galben steril

pământ brun-cenuşiu

piatră şi pietriş

pământ brun-gălbui curat

S IV, CPL 004 G/118, profil de V (fotografie și desen) 


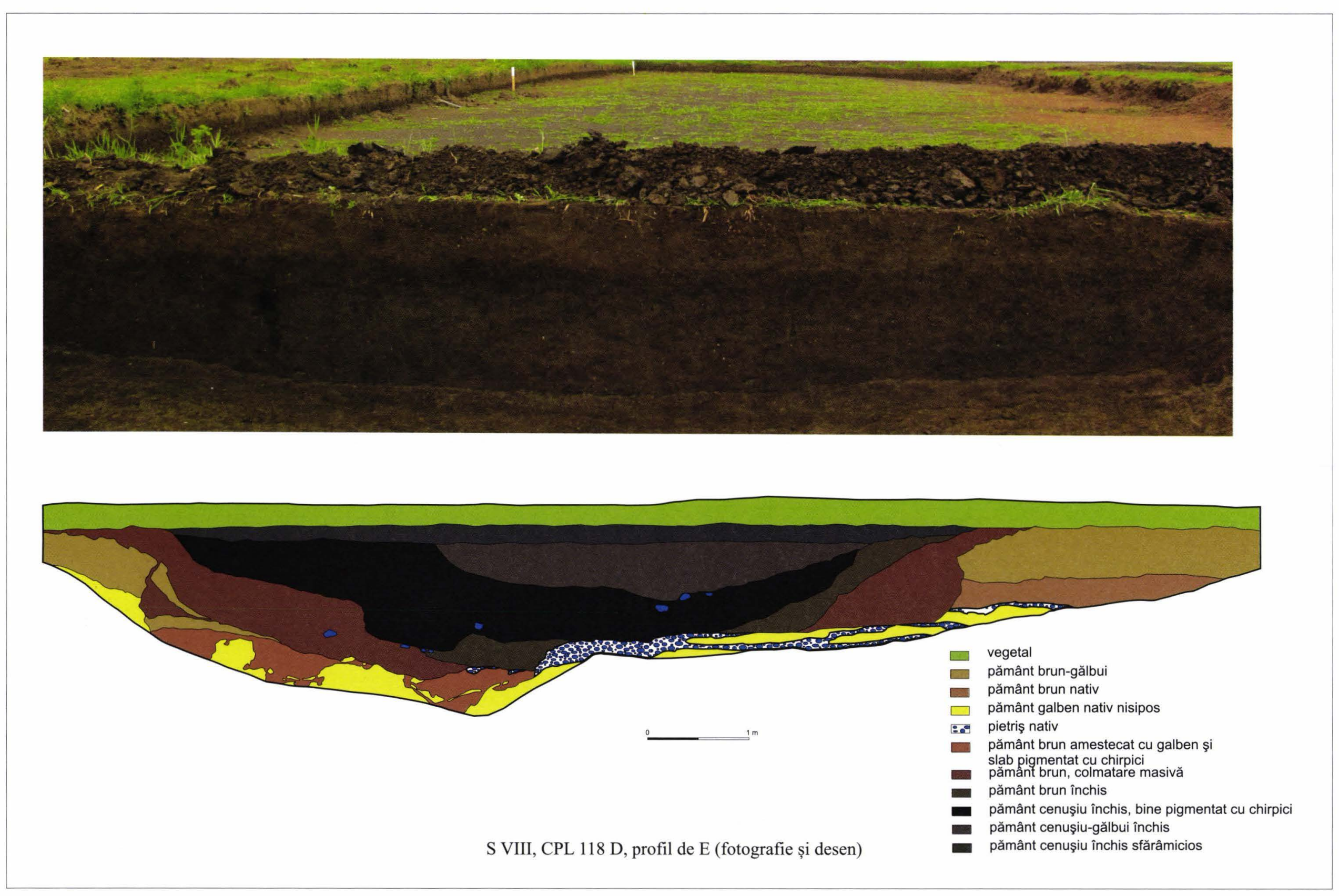

\section{PI. XXVIII}




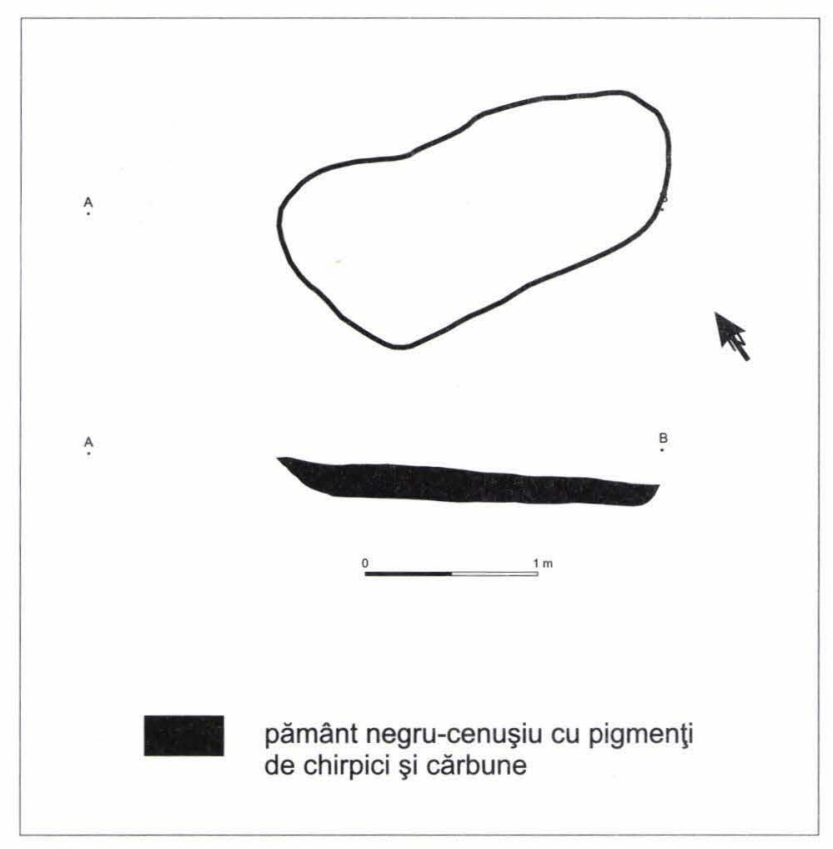

1.

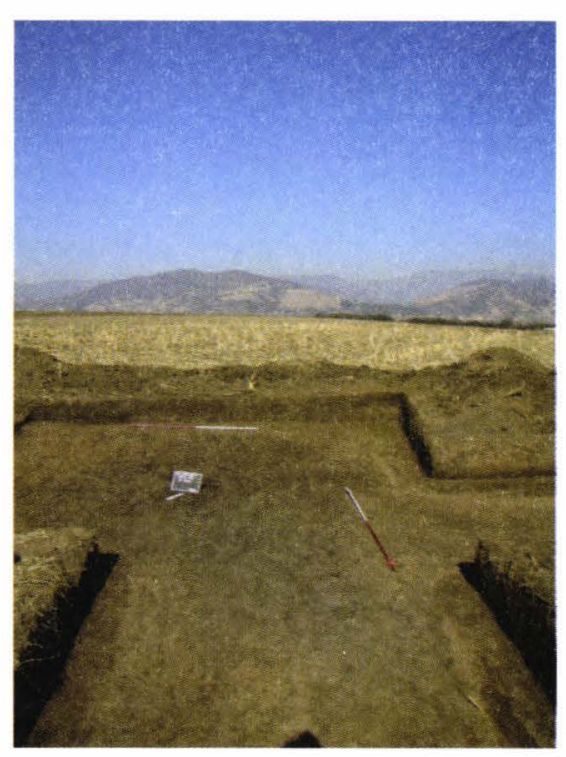

2.

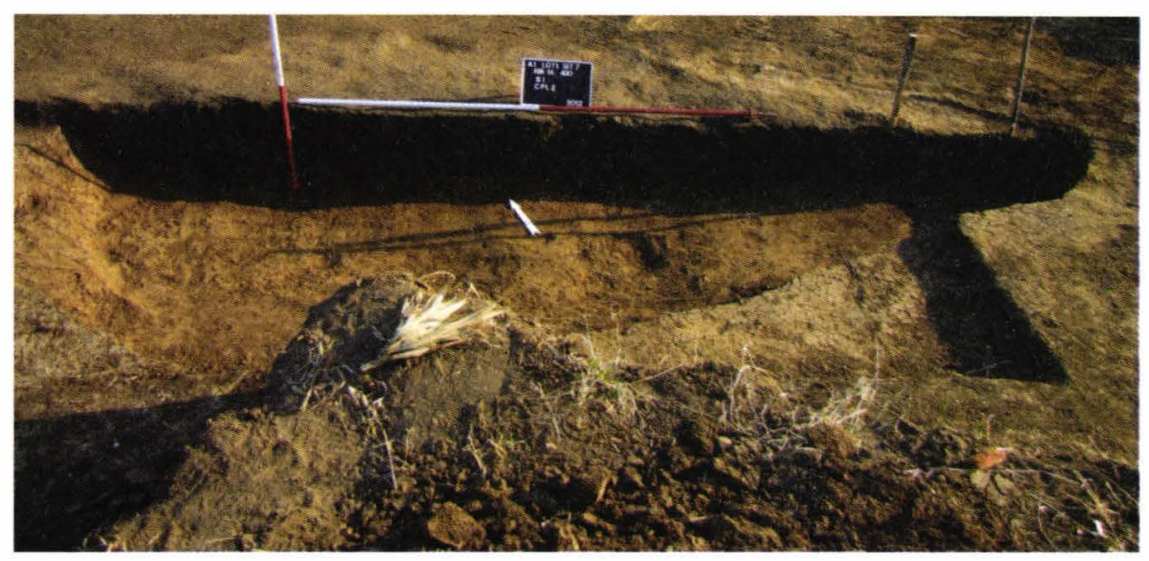

3.

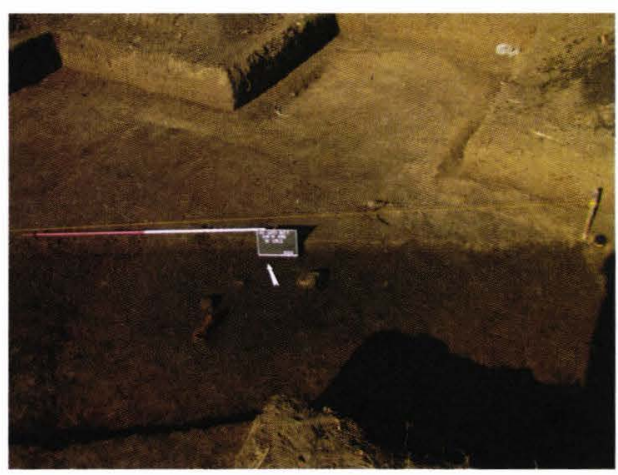

4.

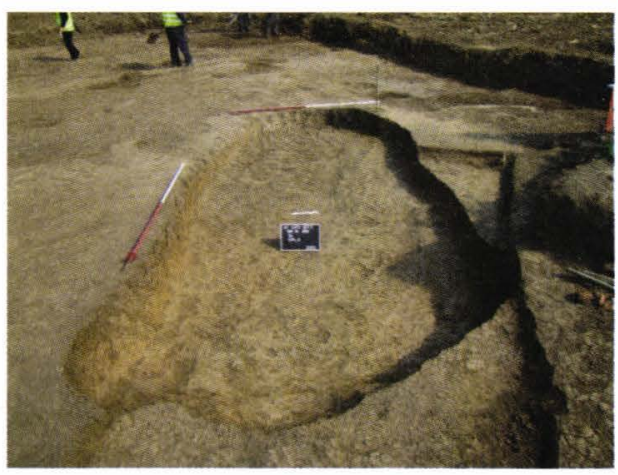

5.

CPL 002: 1. Grund și profil; 2-5. Imagini din timpul cercetării complexului 

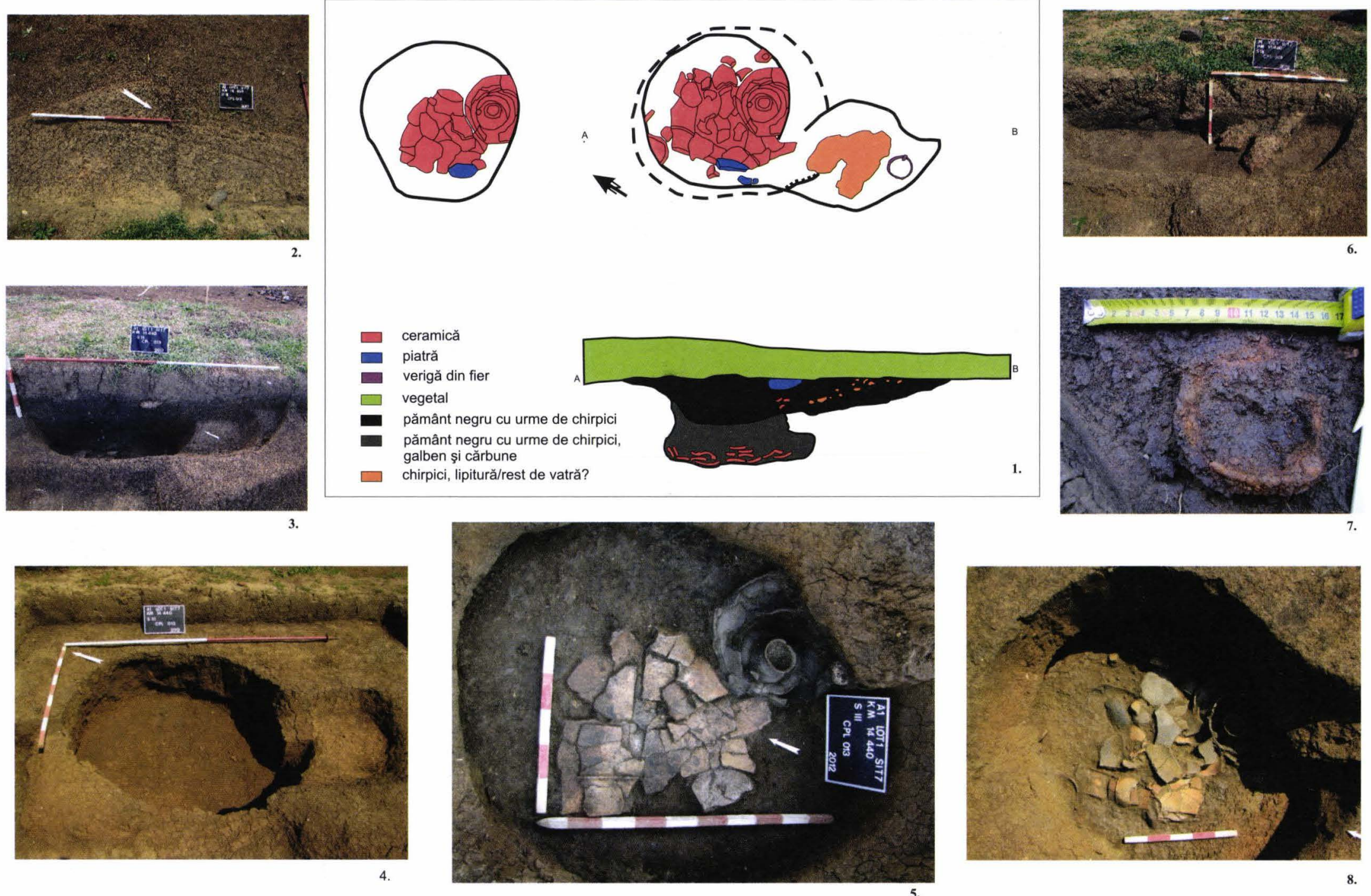

CPL 013: 1. Grund și profil; 2-8. Imagini din timpul cercetării complexului

PI. XXX 


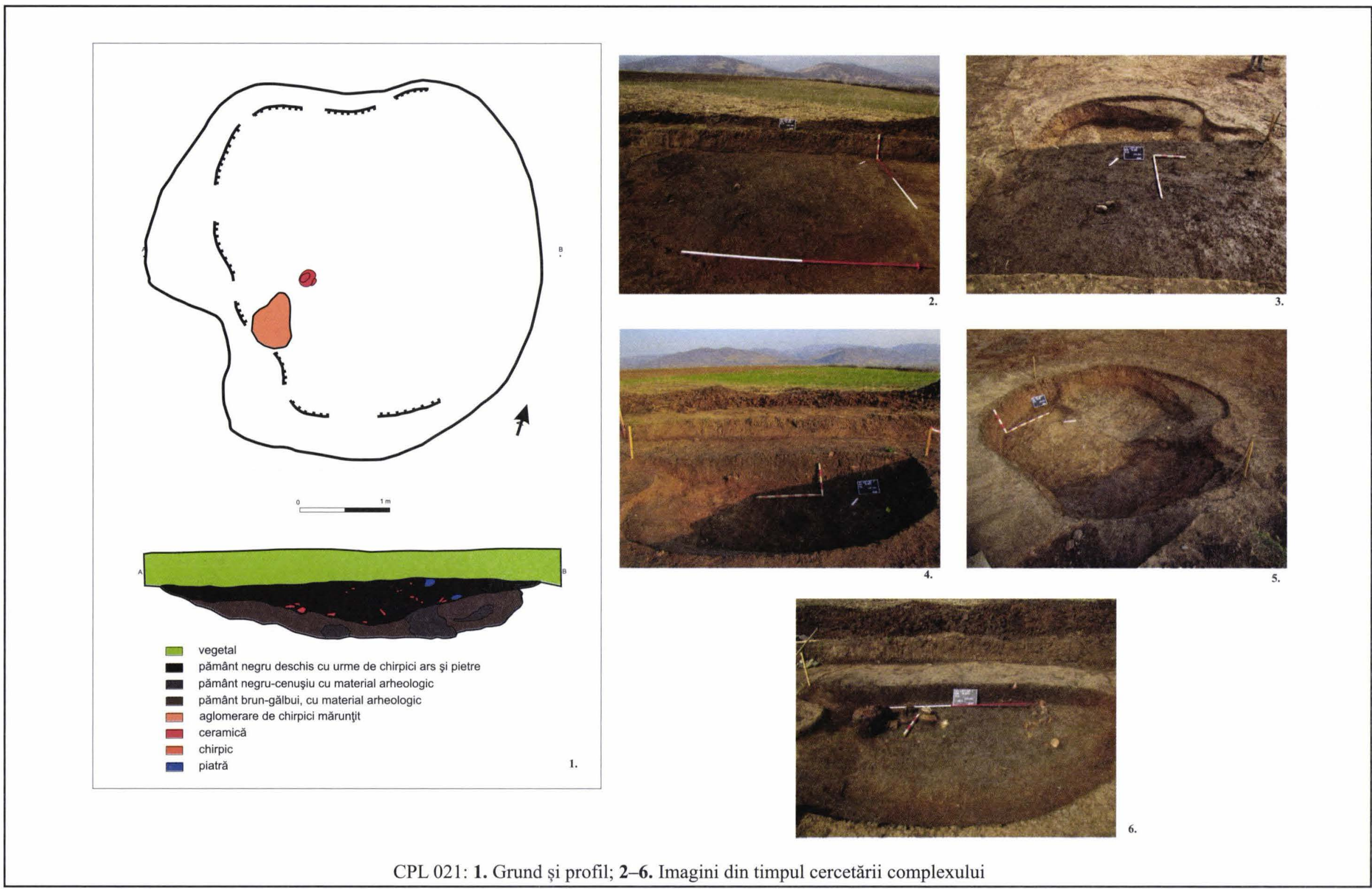

PI. XXXI 

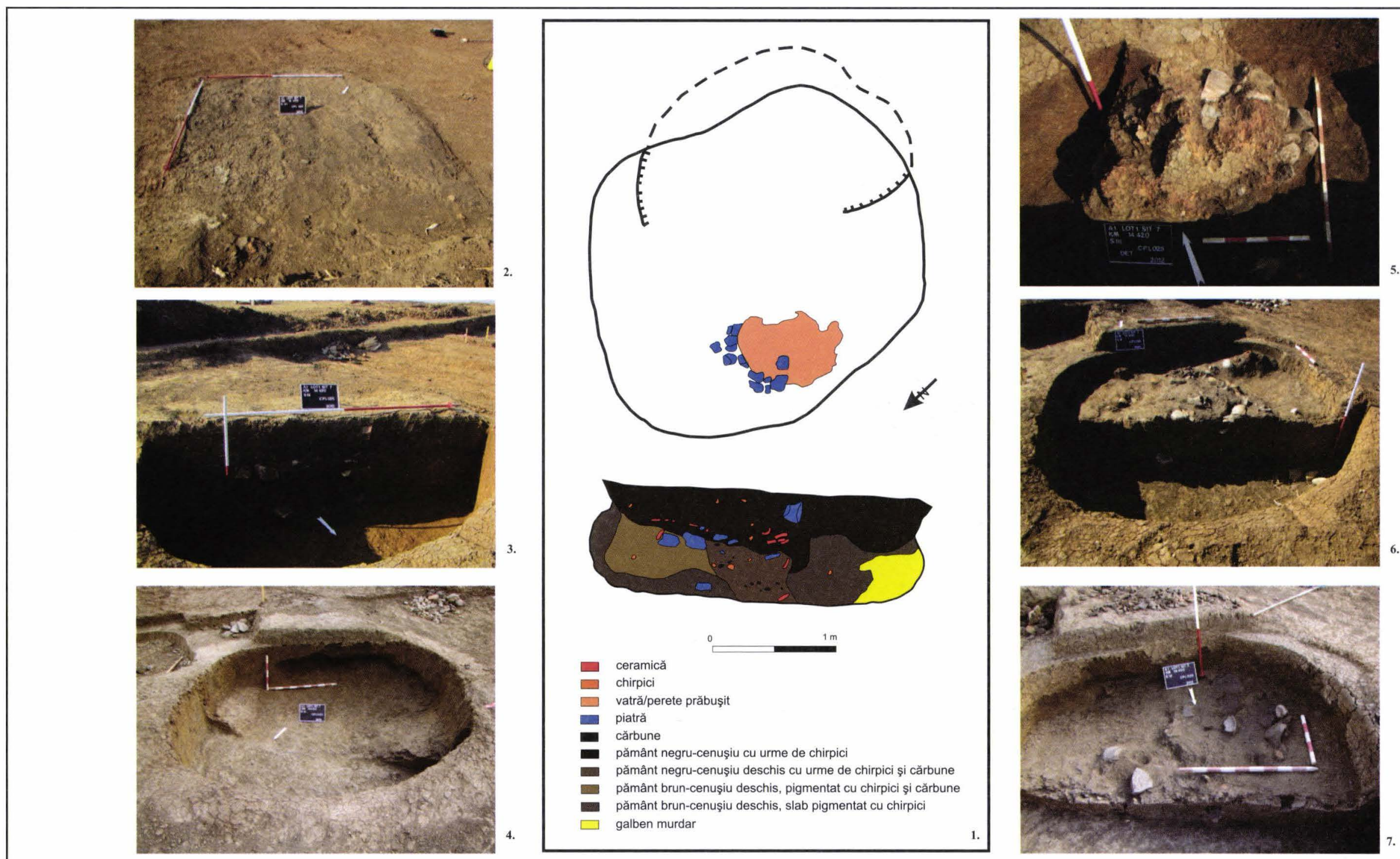

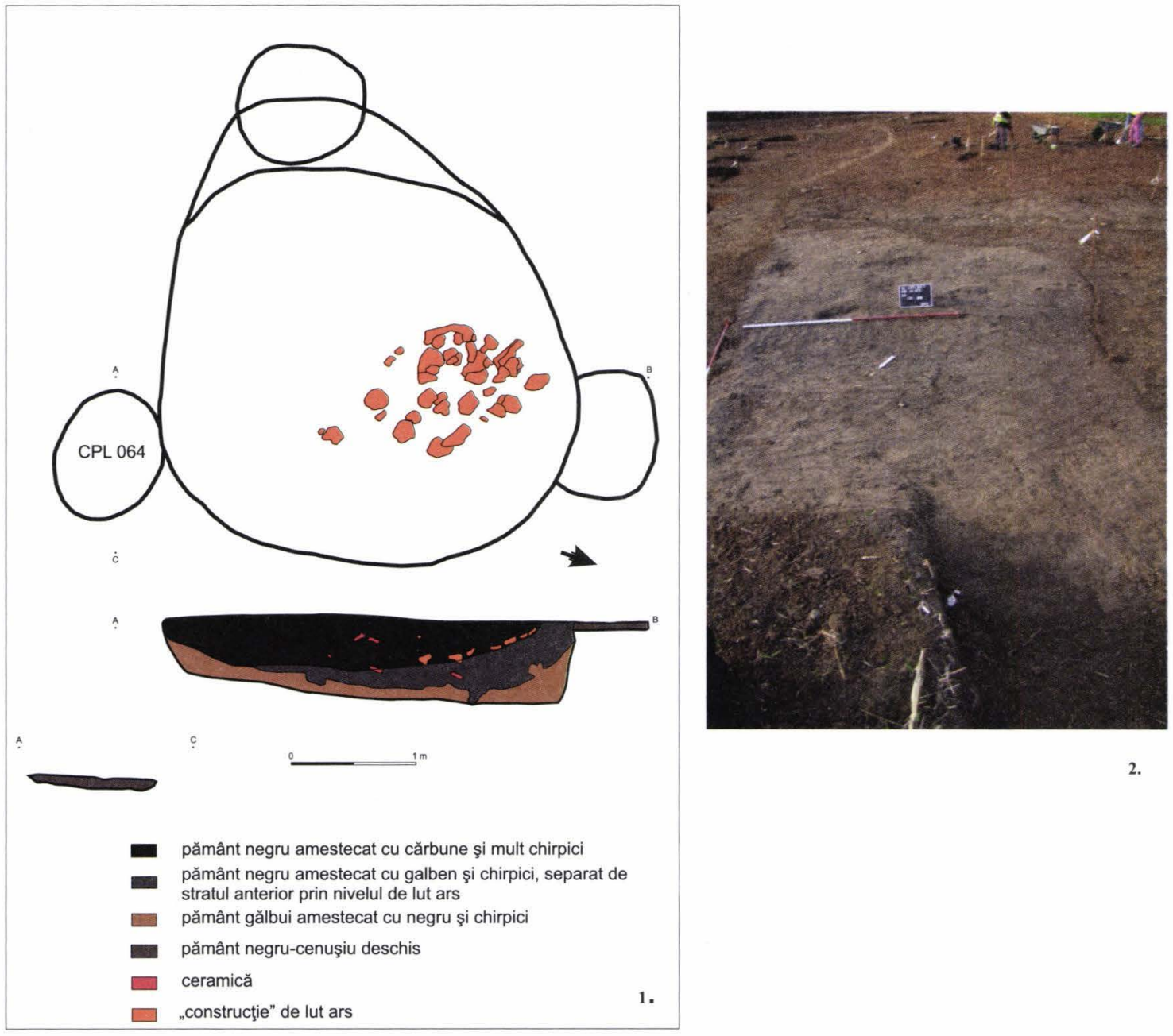

2.
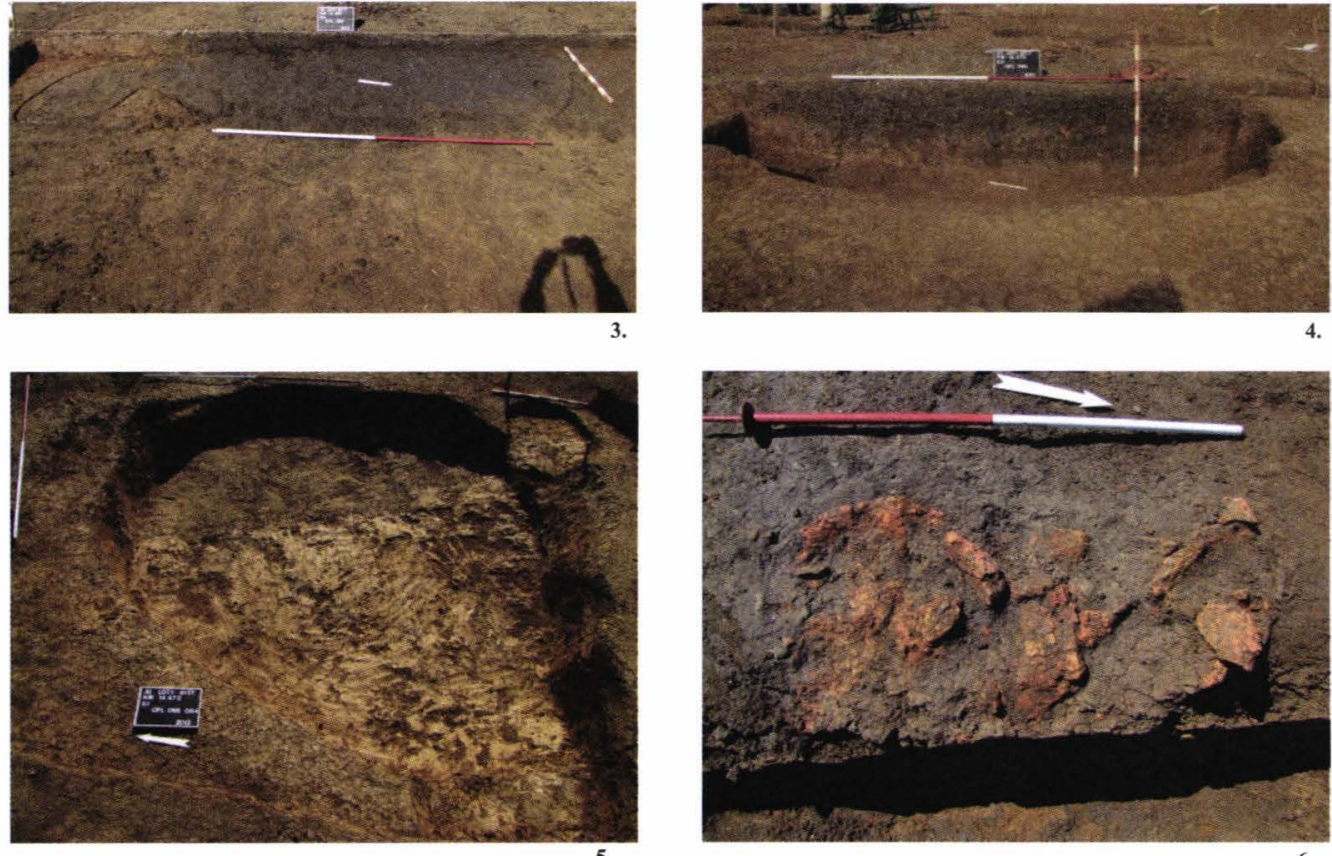

CPL 066: 1. Grund și profil; 2-6. Imagini din timpul cercetării complexului 


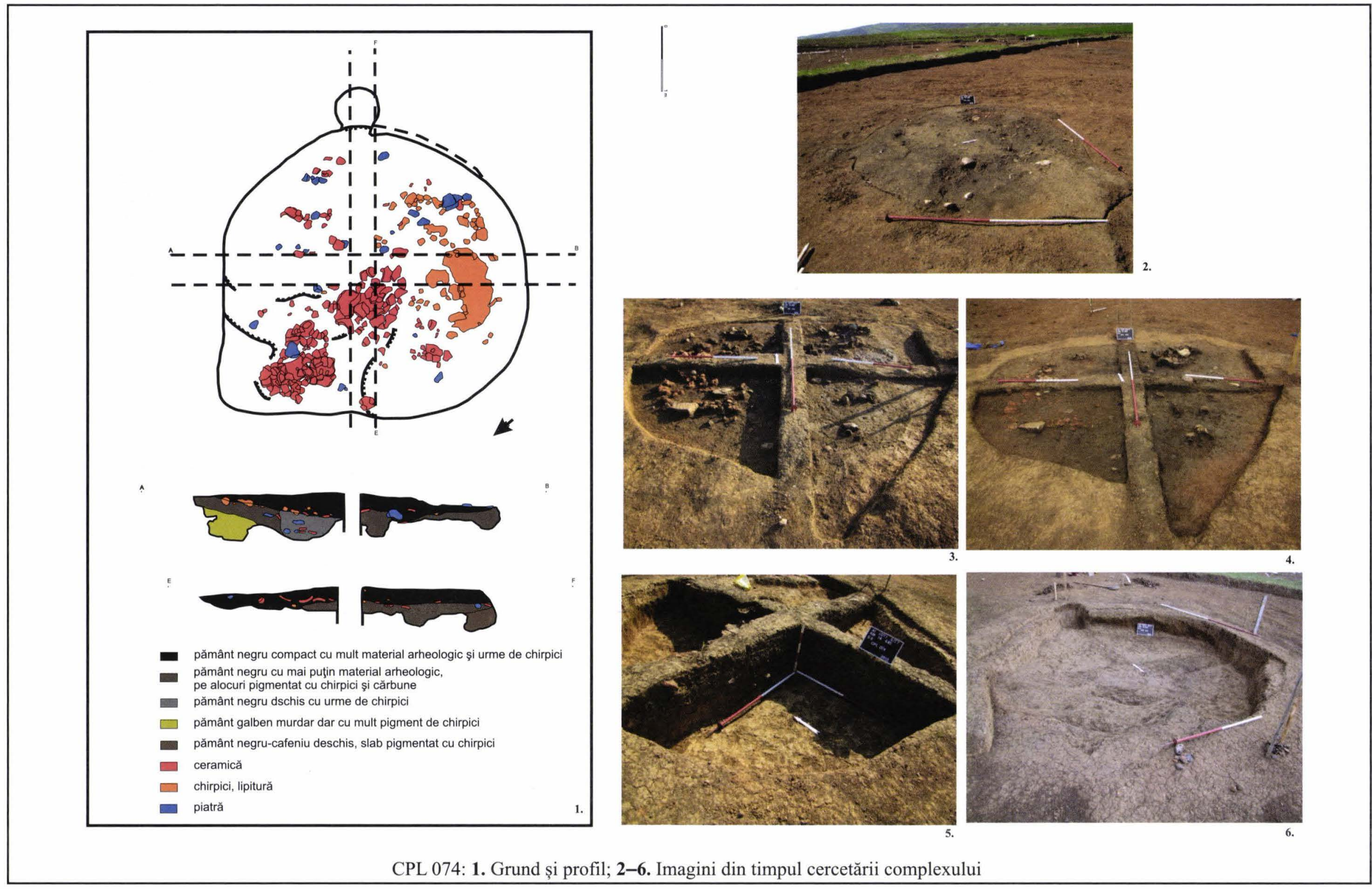

PI. XXXIV 


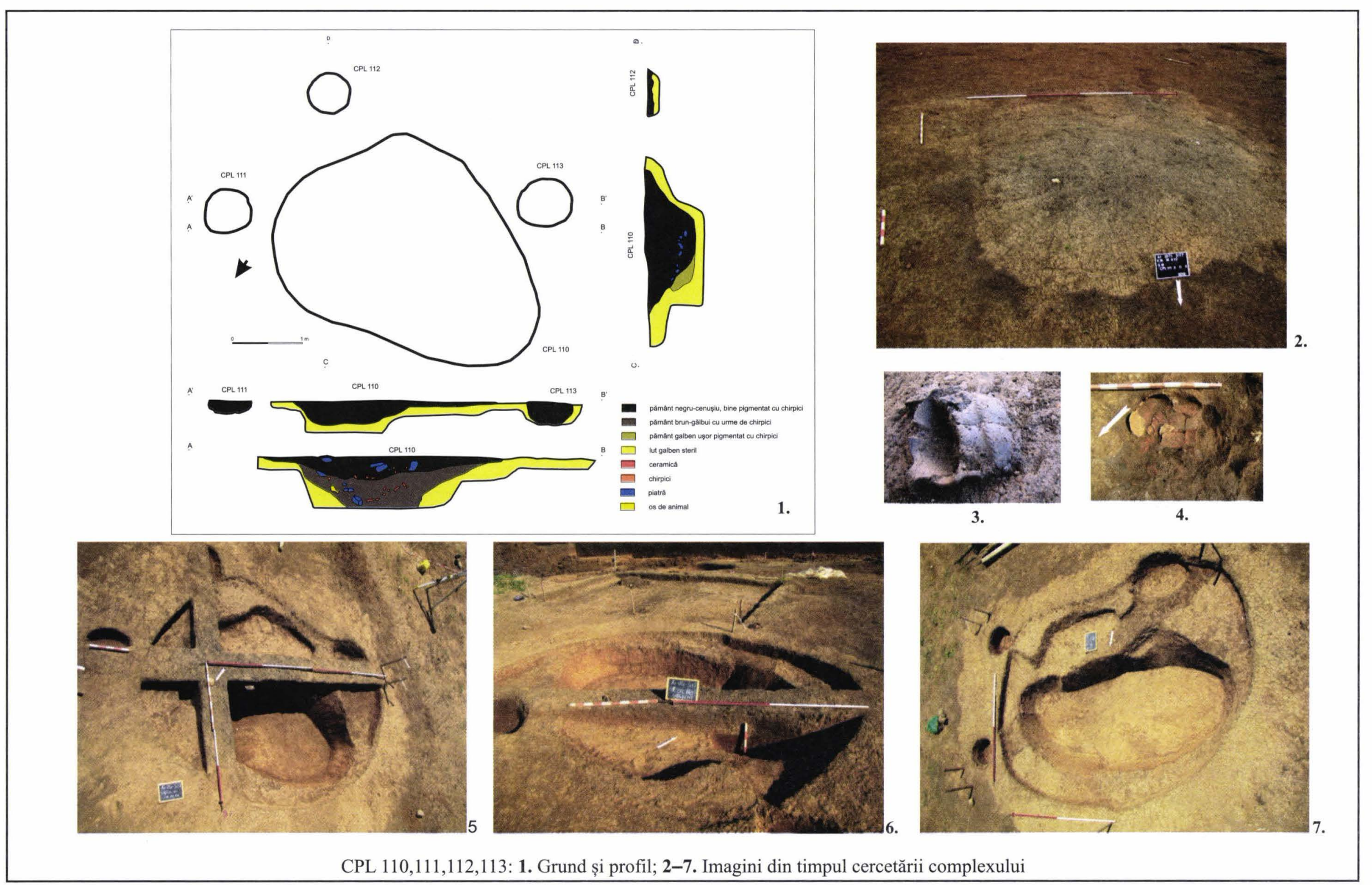

PI. XXXV 

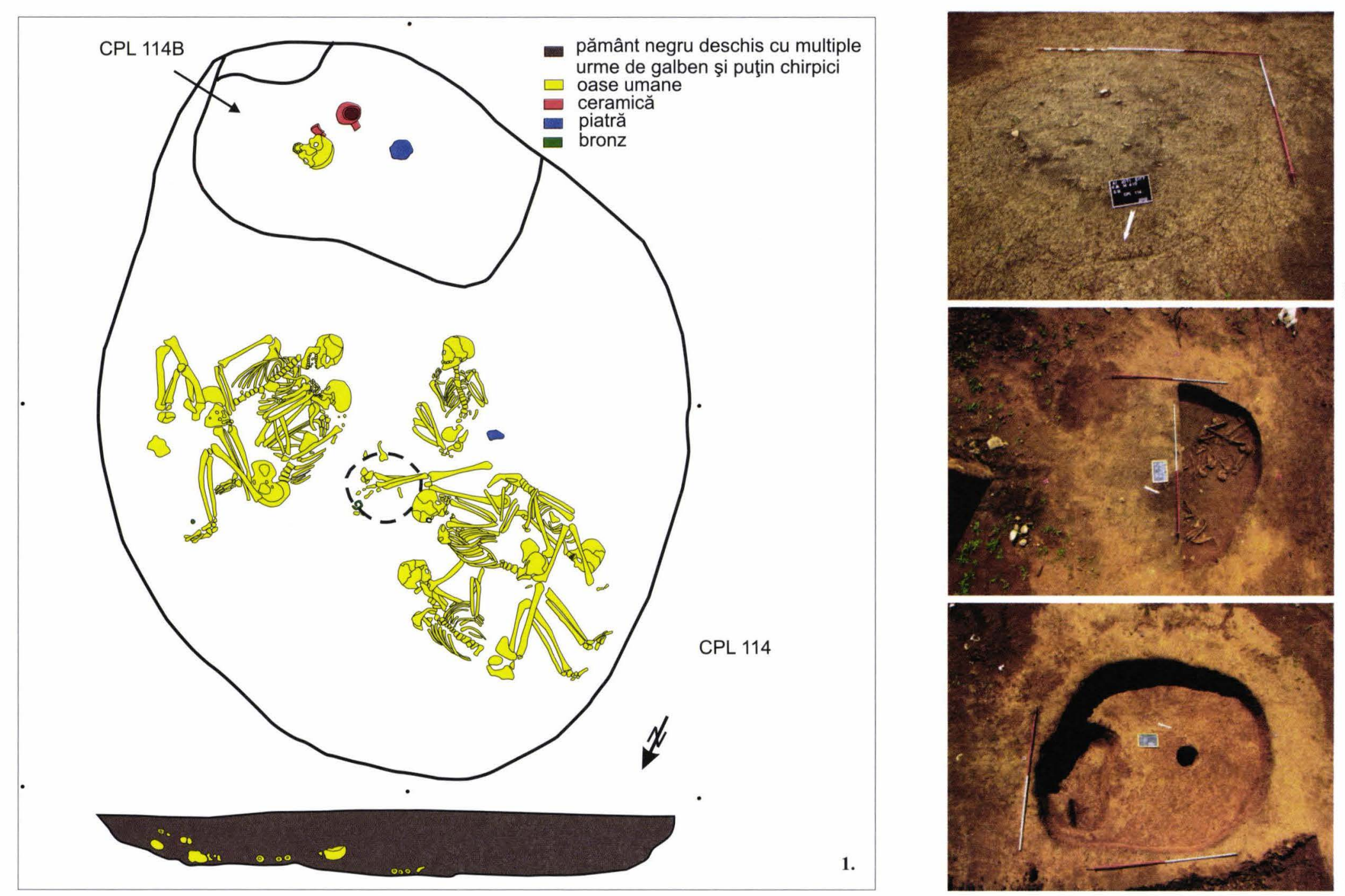

2.

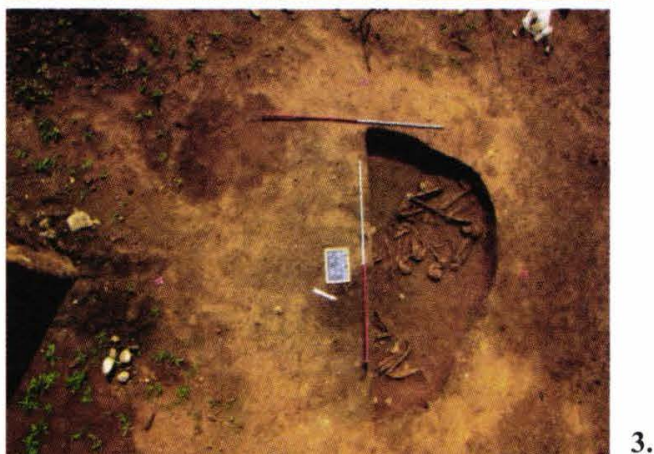

3.

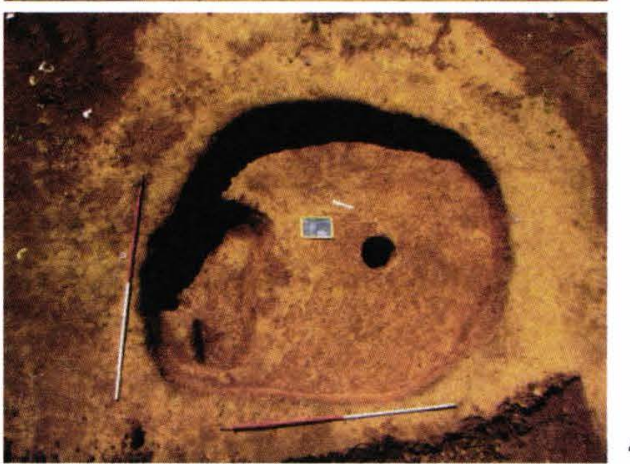




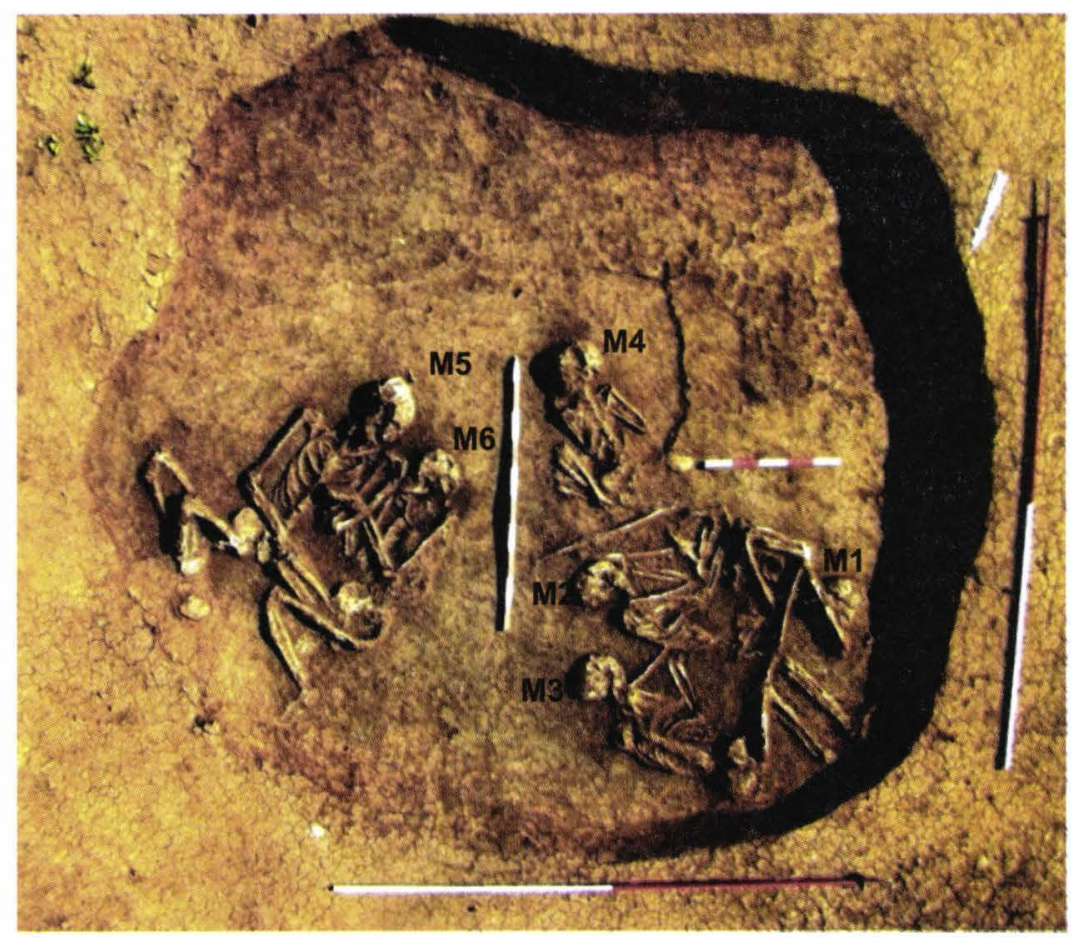

1.

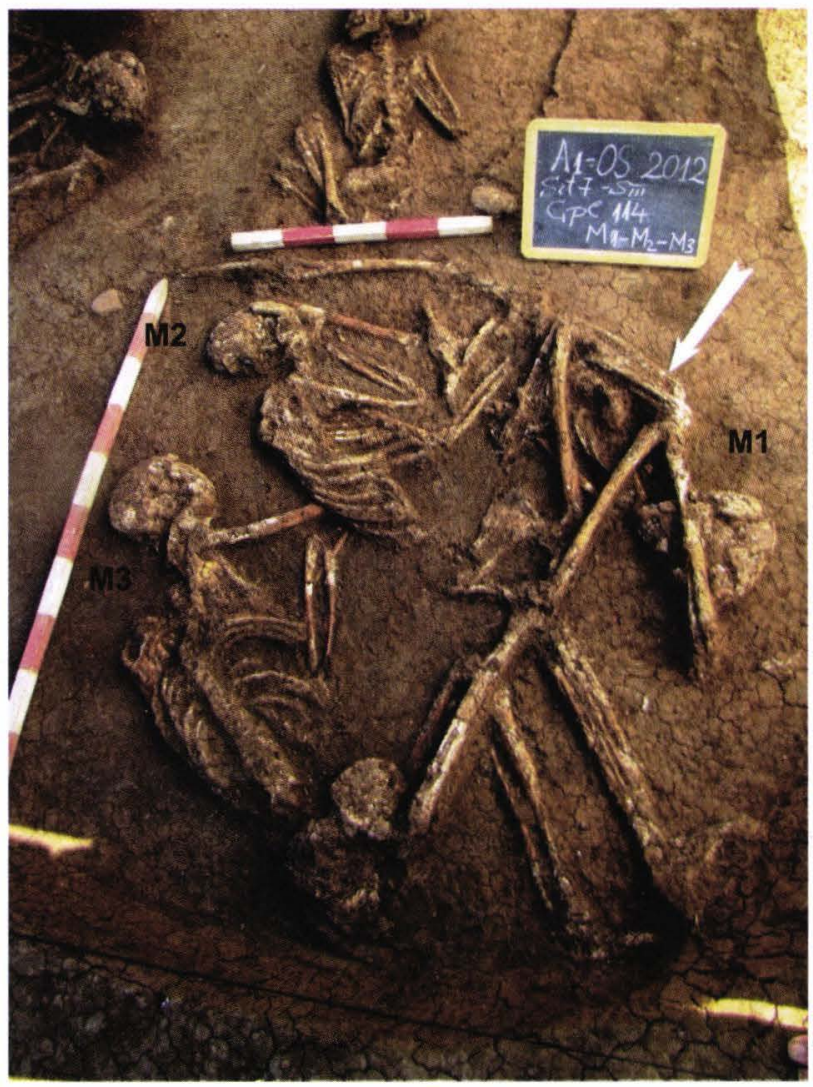

2.
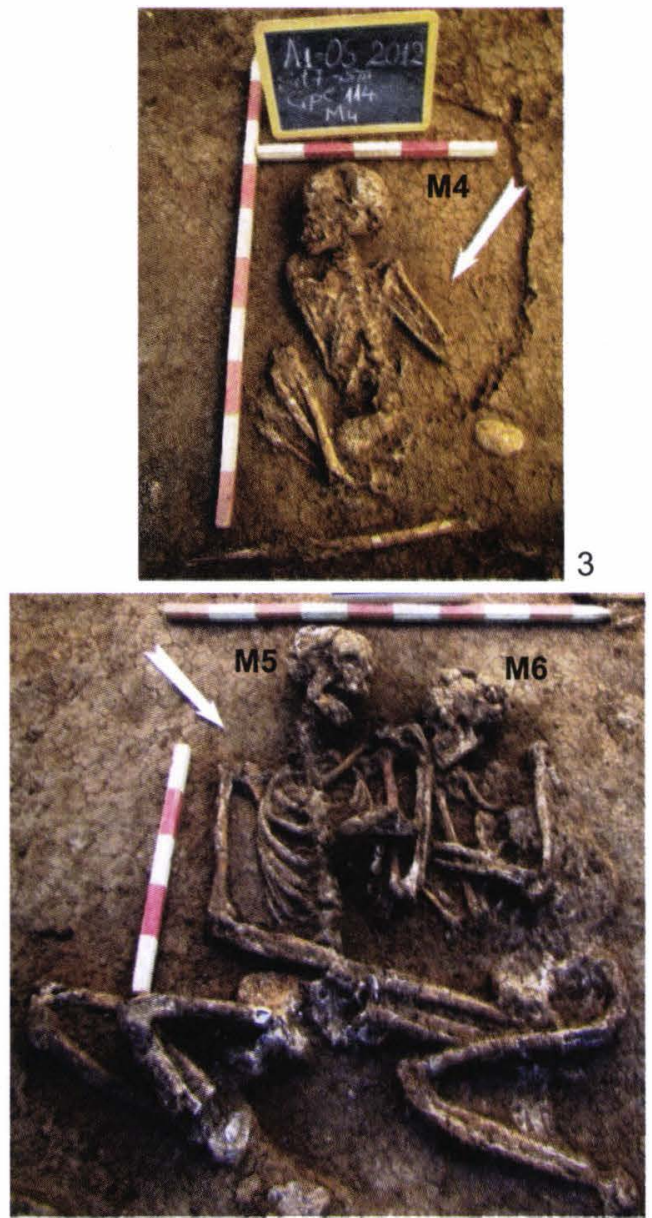

4.

1. CPL 114 („mormânt colectiv”) imagine de ansamblu; 2. M1 (dreapta sus), M2 (centru), M3 (stânga jos); 3. M4; 4. M5 (stânga), M6 (dreapta) 


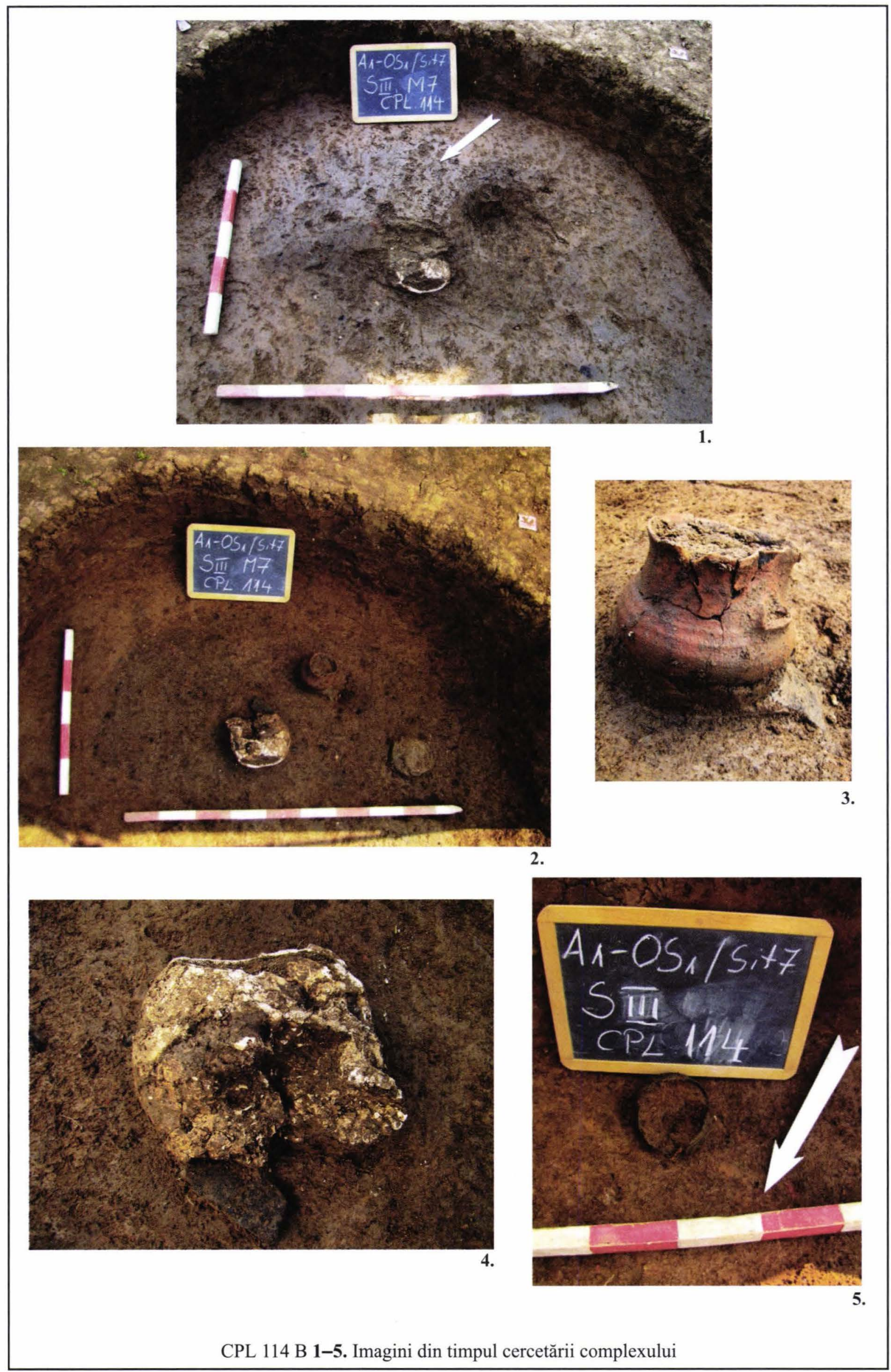




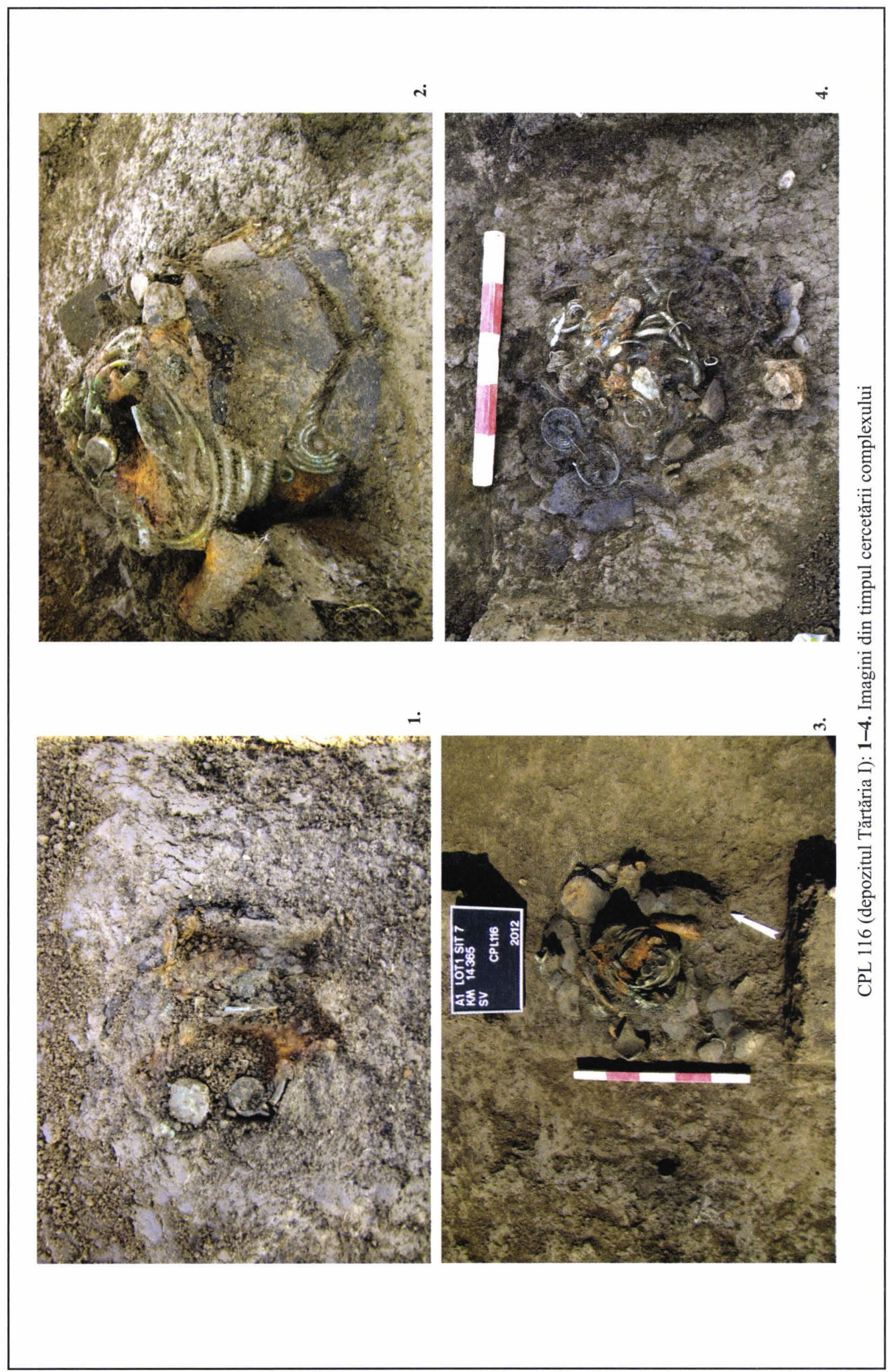



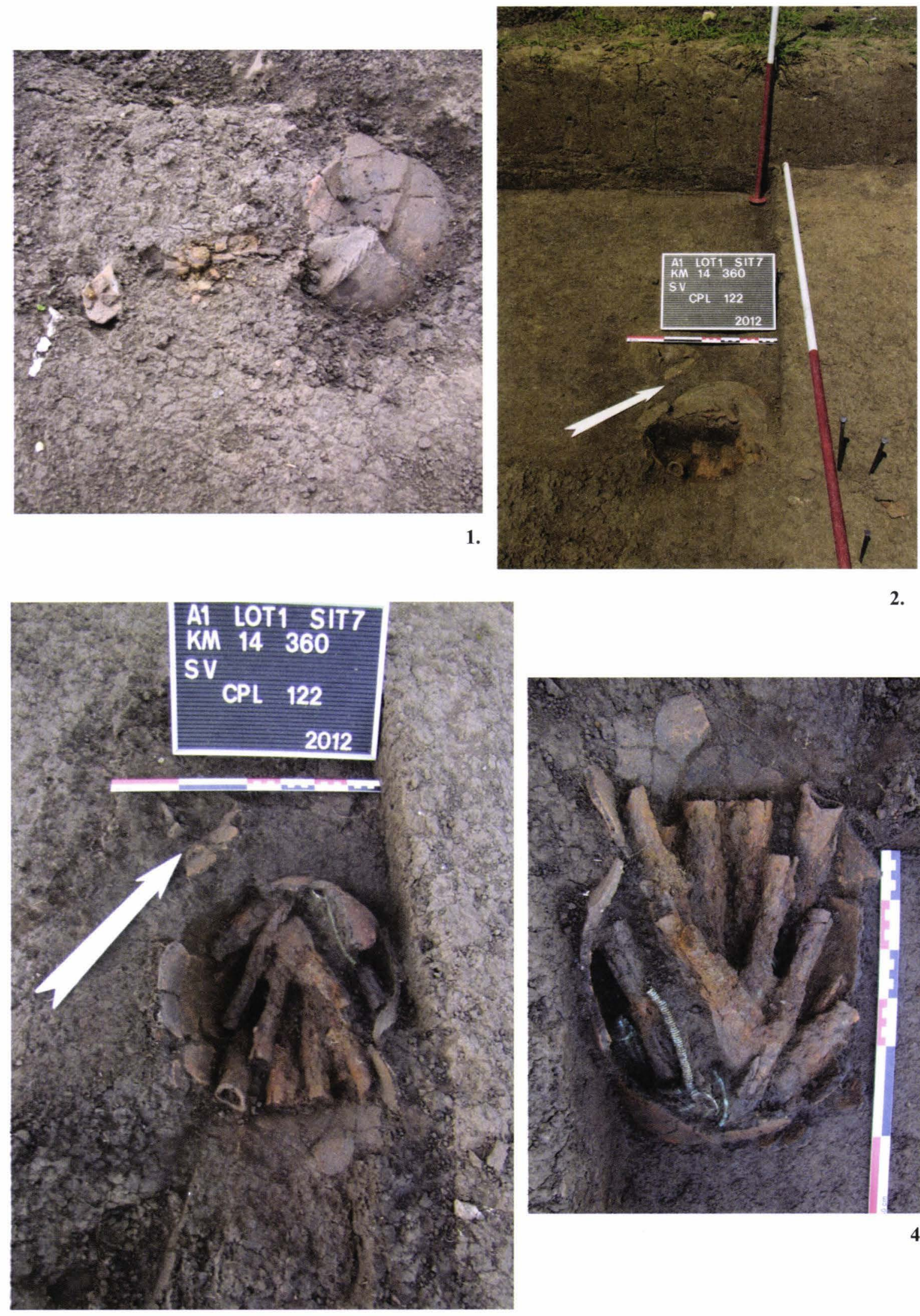

2.

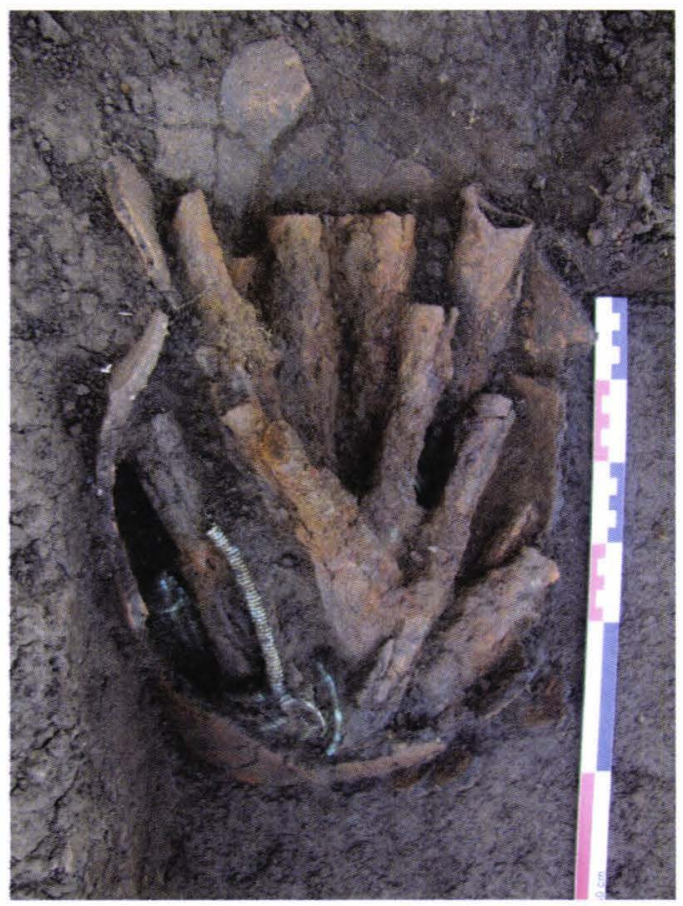

3.

CPL 122 (depozitul Tărtăria II): 1-6. Imagini din timpul cercetării complexului 


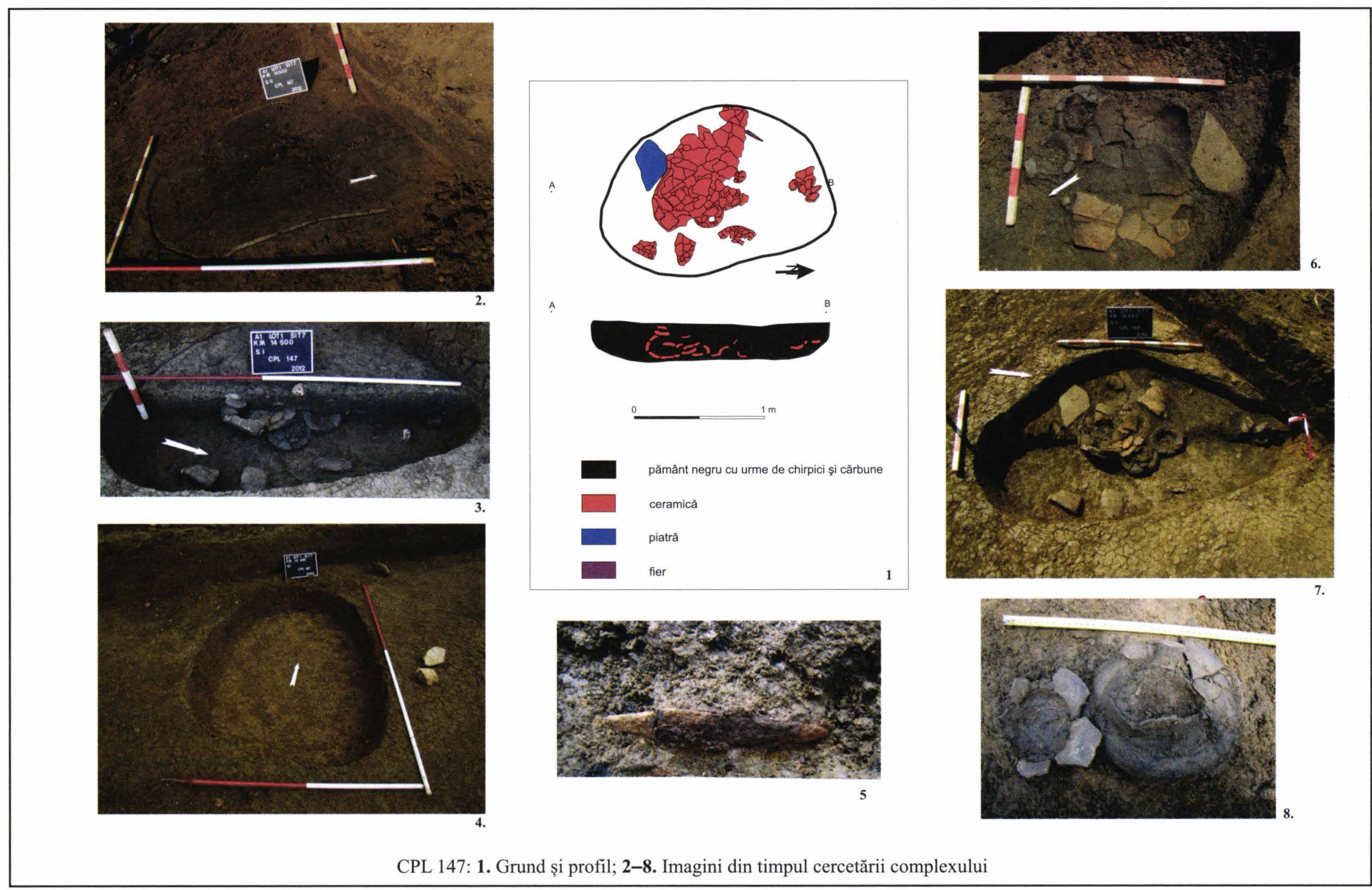

PI. XLI 


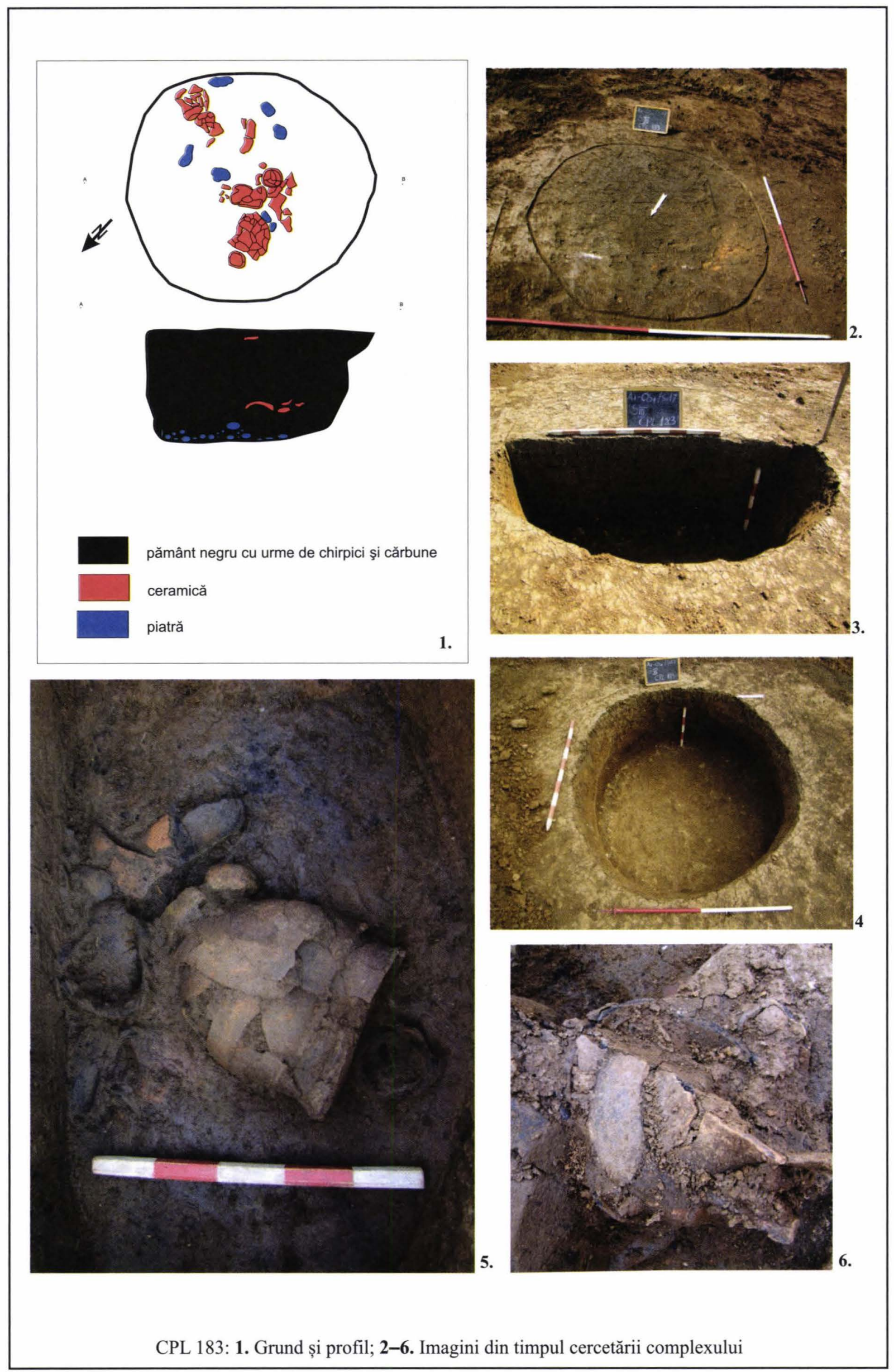



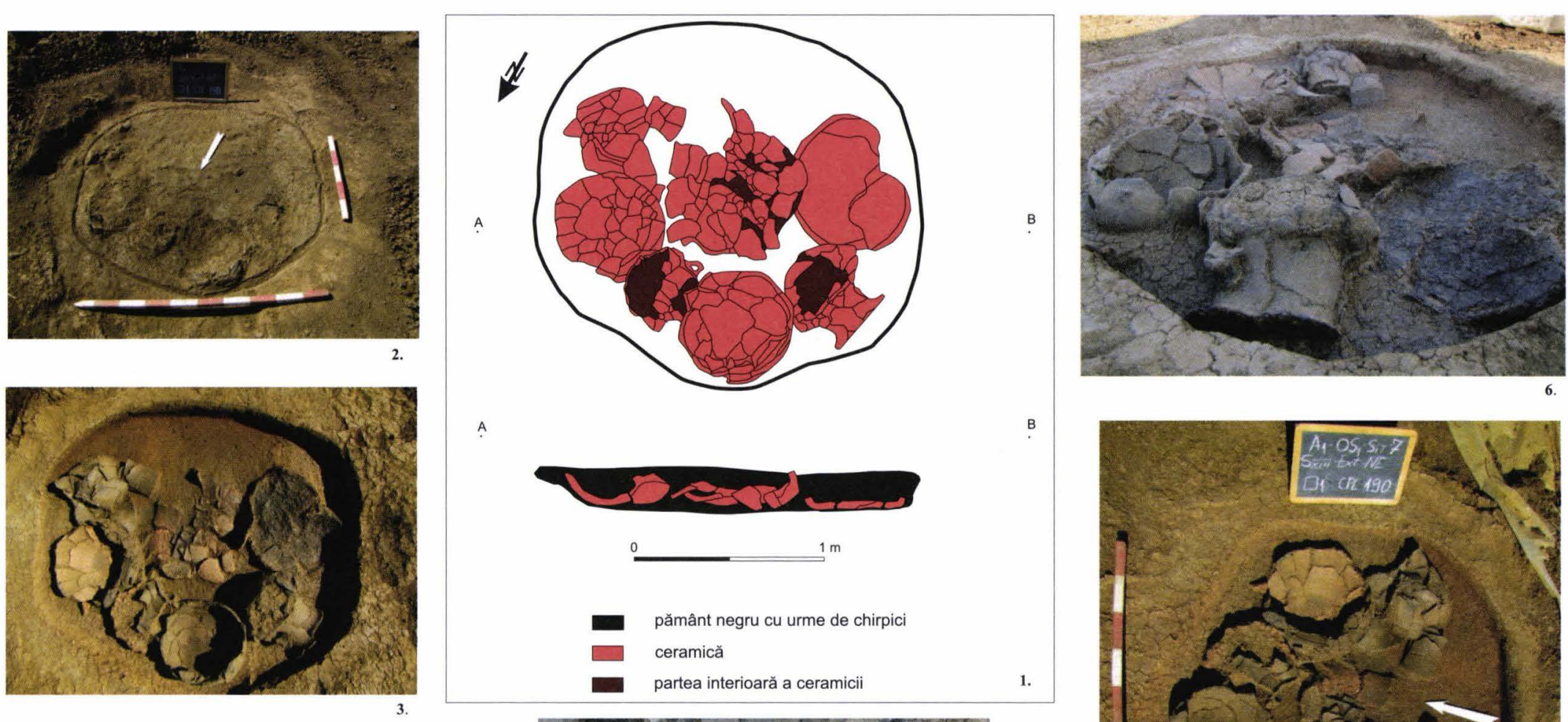

A.
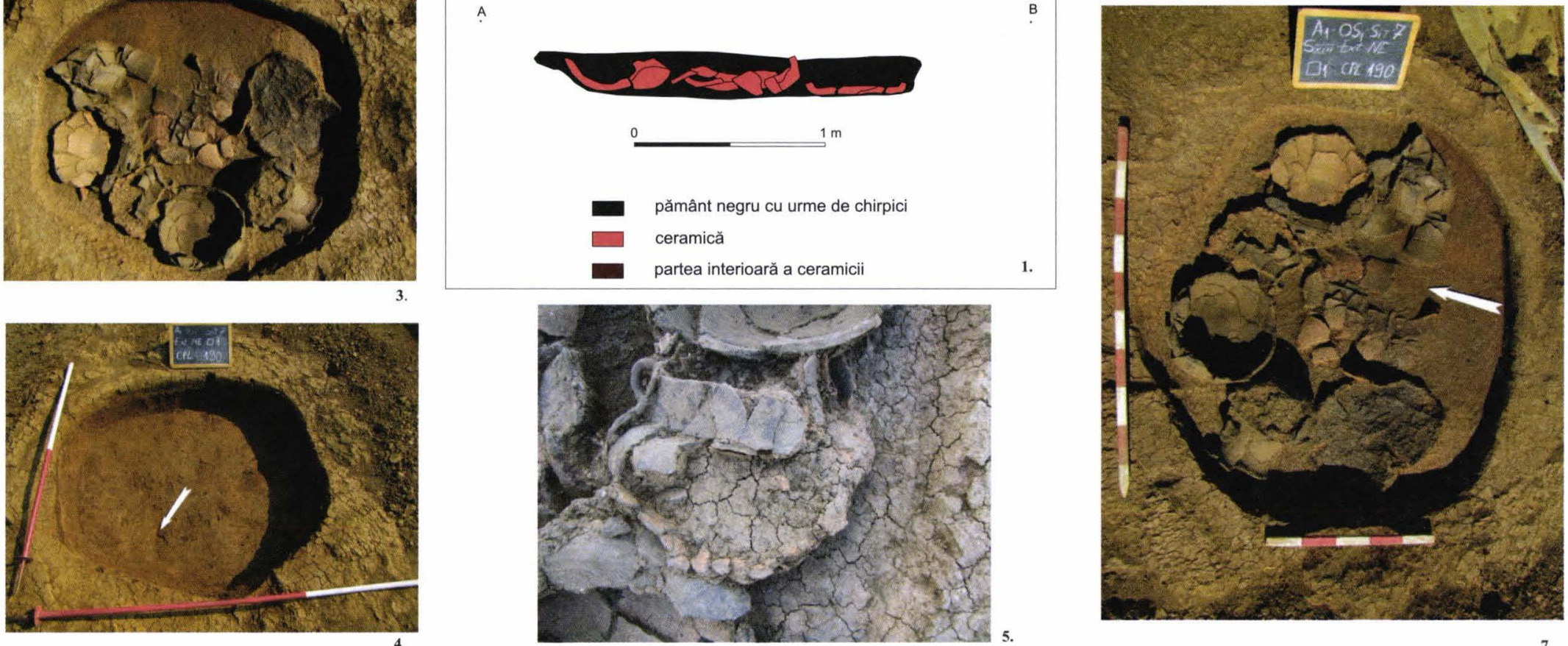

CPL 190: 1. Grund și profil; 2-7. Imagini din timpul cercetării complexului 


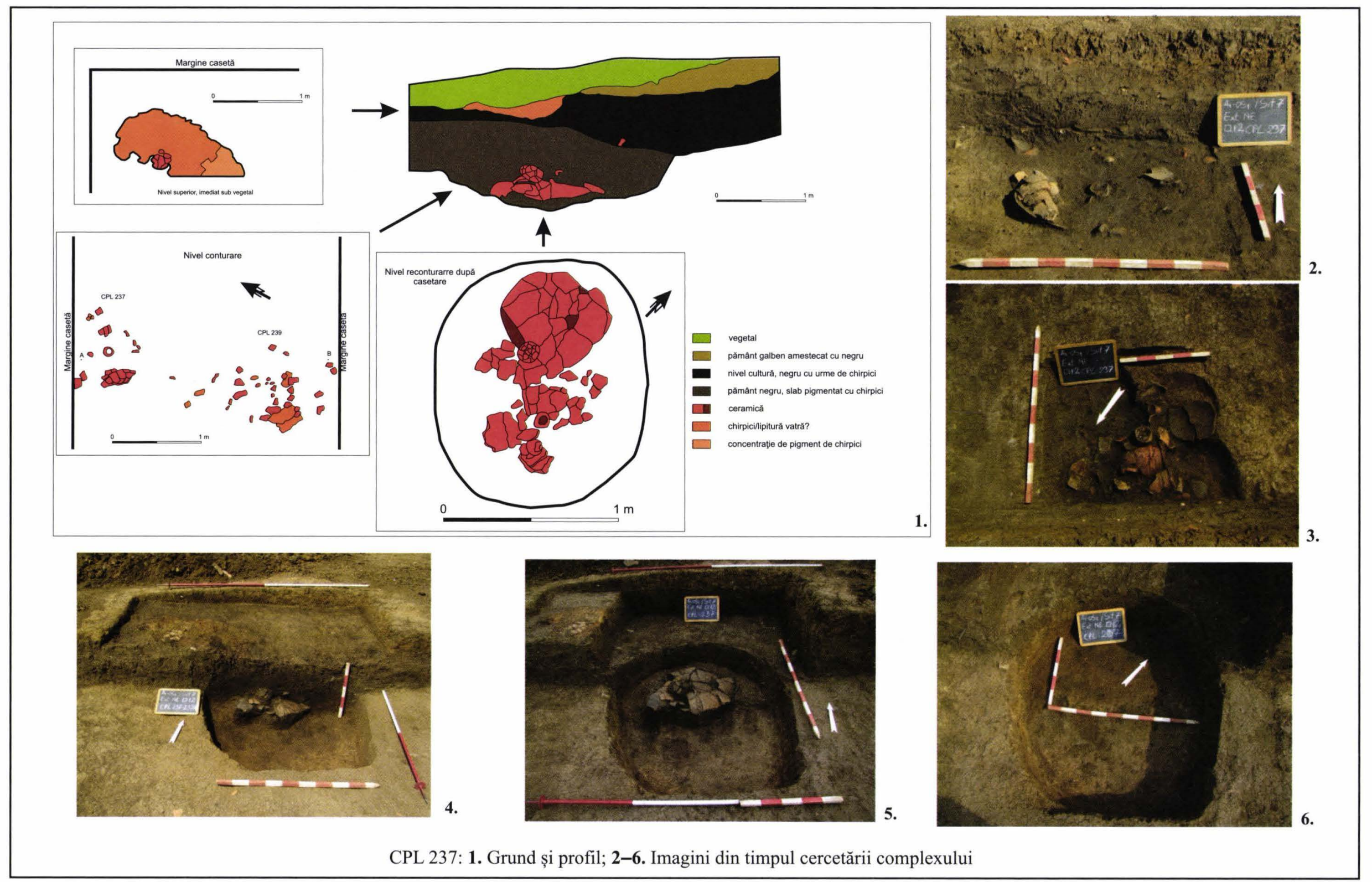

PI. XLIV 

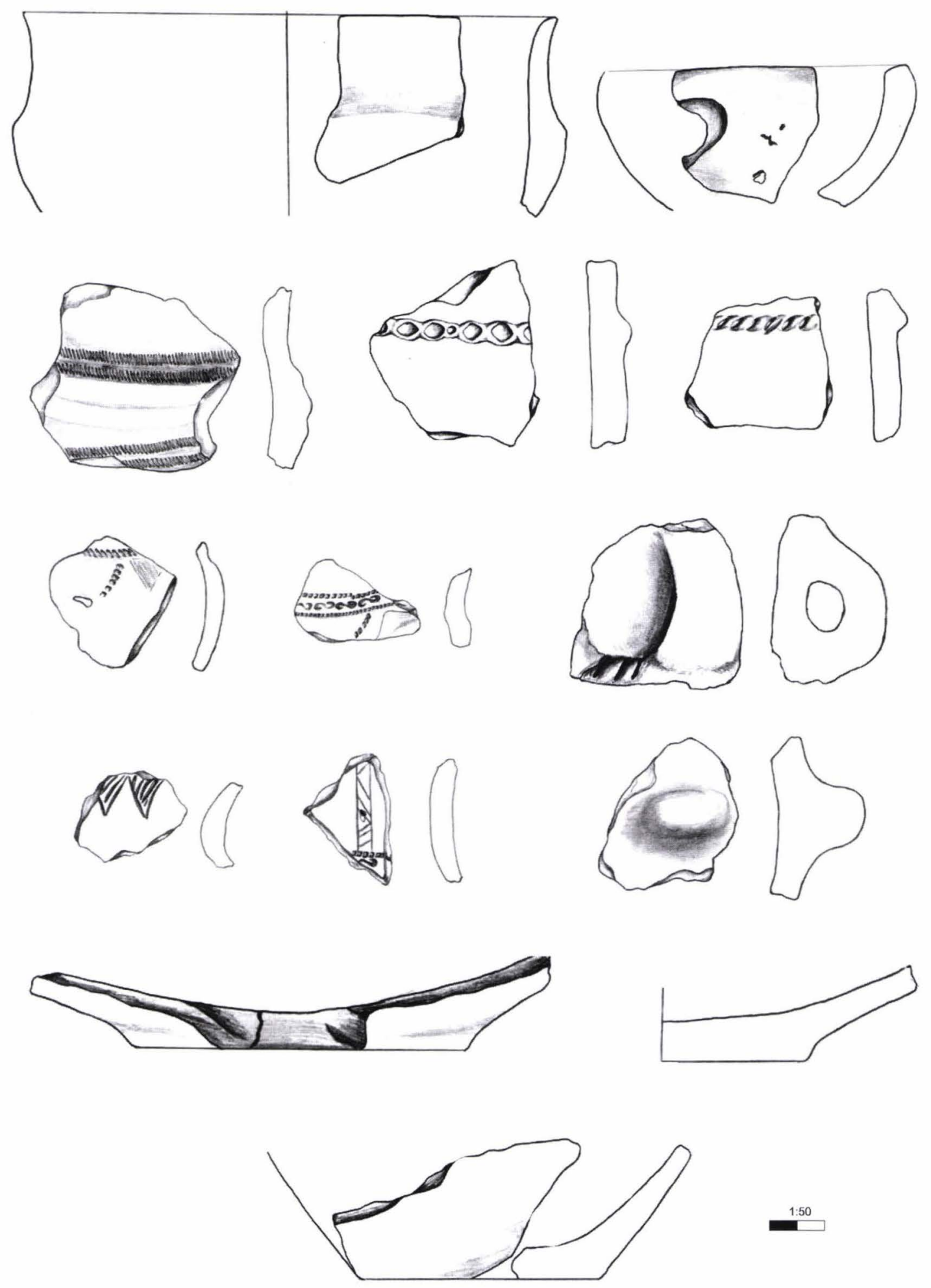


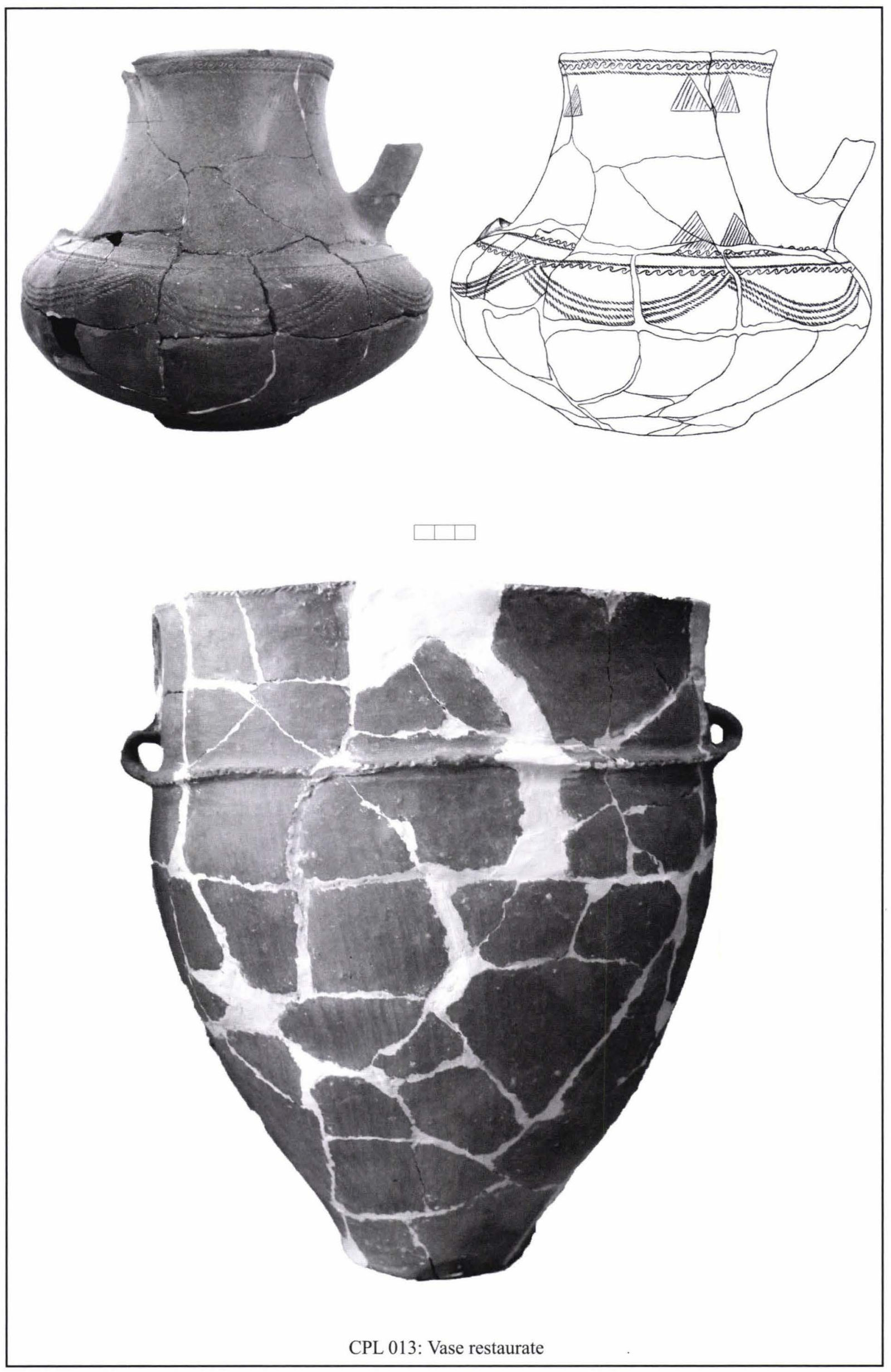

PI. XLVI 


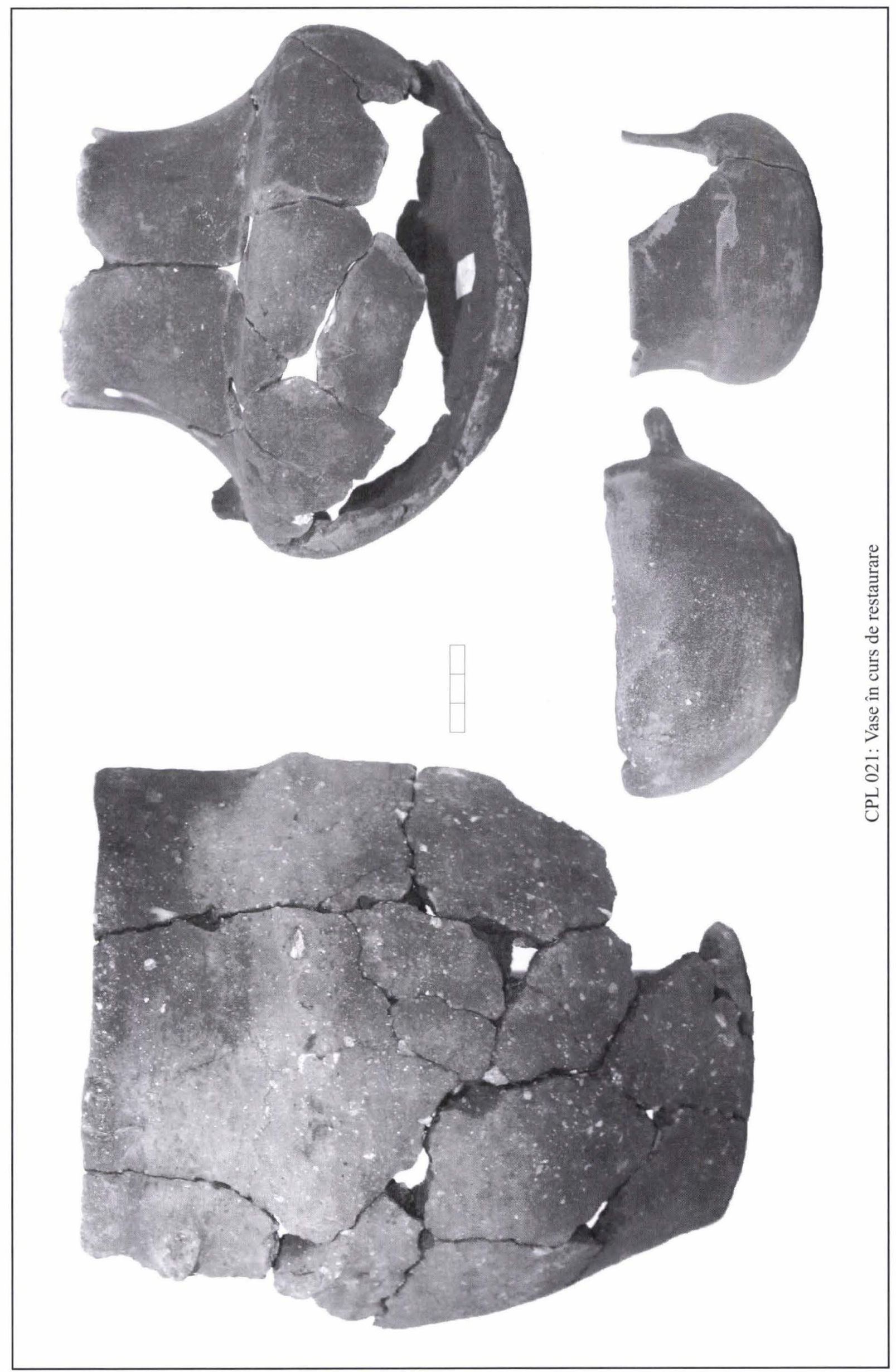

$\frac{3}{2}$ 

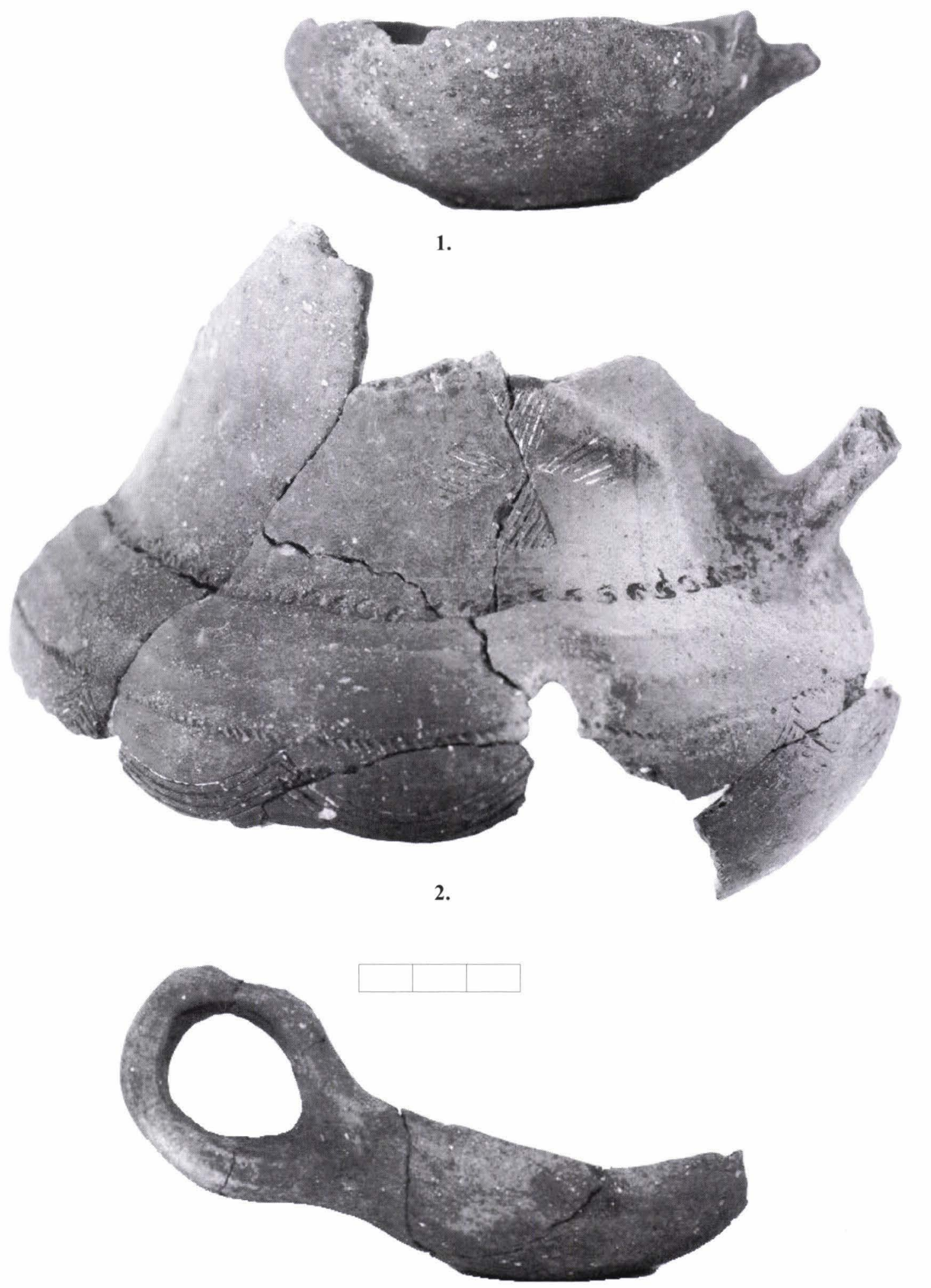

3.

CPL 074: Vase în curs de restaurare 

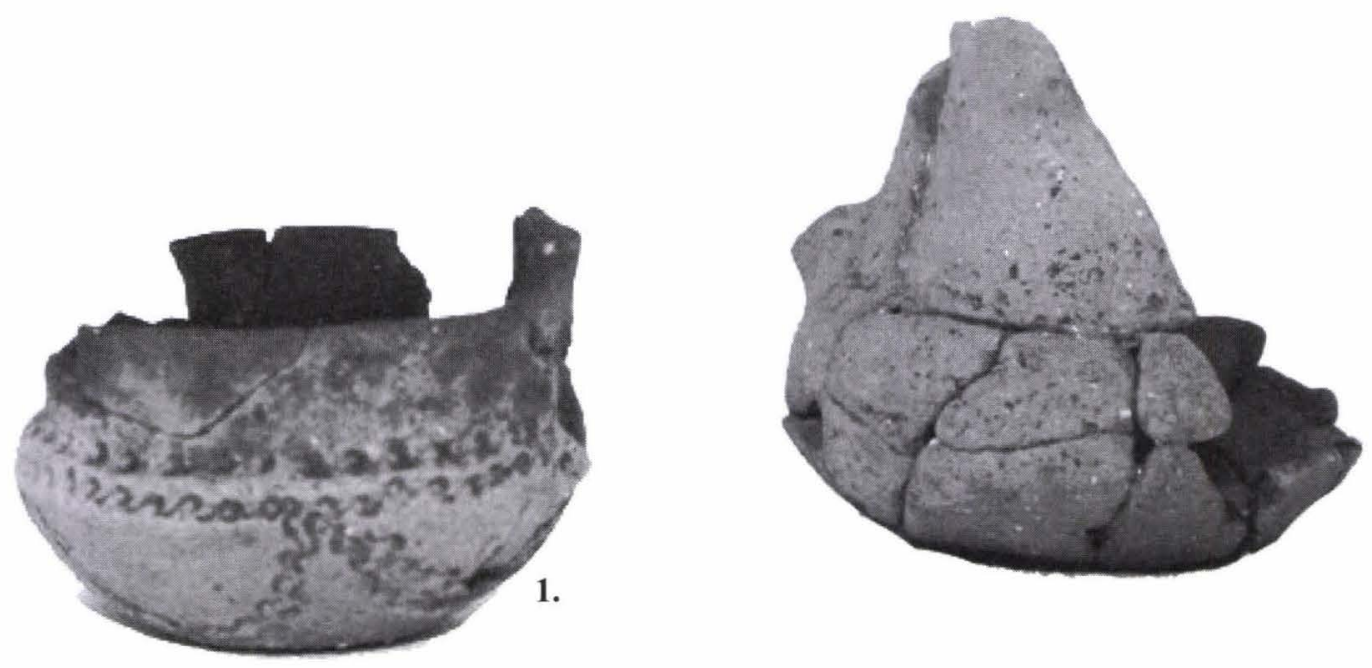

2.

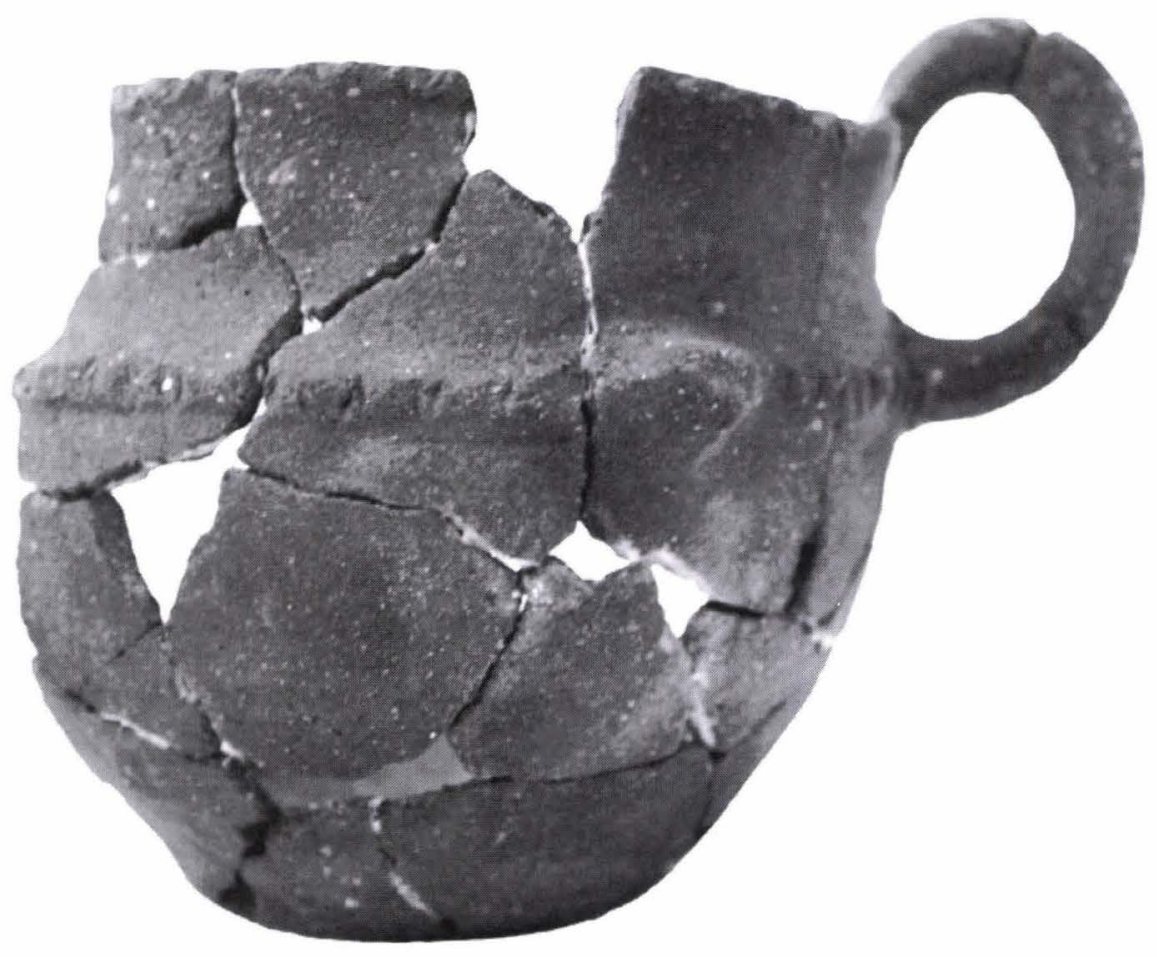

3.

1-2. CPL. 066, 3. CPL. 110: Vase în curs de restaurare

PI. XLIX 


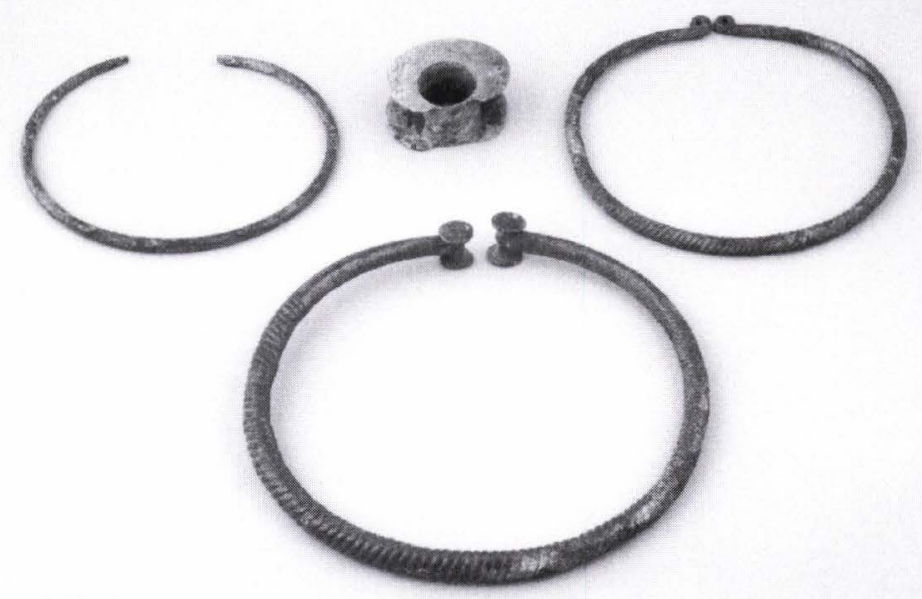

1.

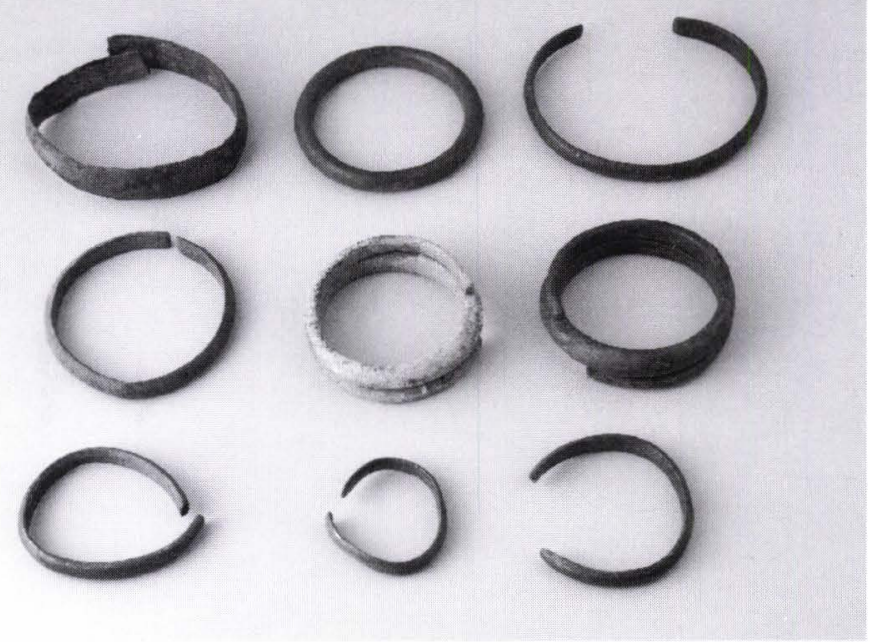

2.

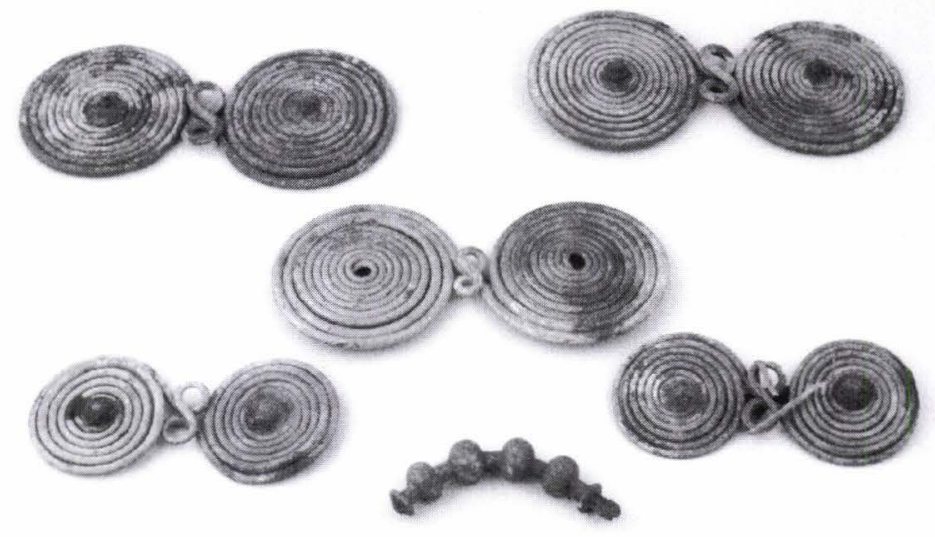

3.

Piese de port din depozitele Tărtăria I și Tărtăria II:1. Torquesuri şi pandantiv din depozitul Tărtăria I; 2. Brățări din depozitul Tărtăria I; 3. Fibule din depozitele Tărtăria I și Tărtăria II

\section{PI. L}




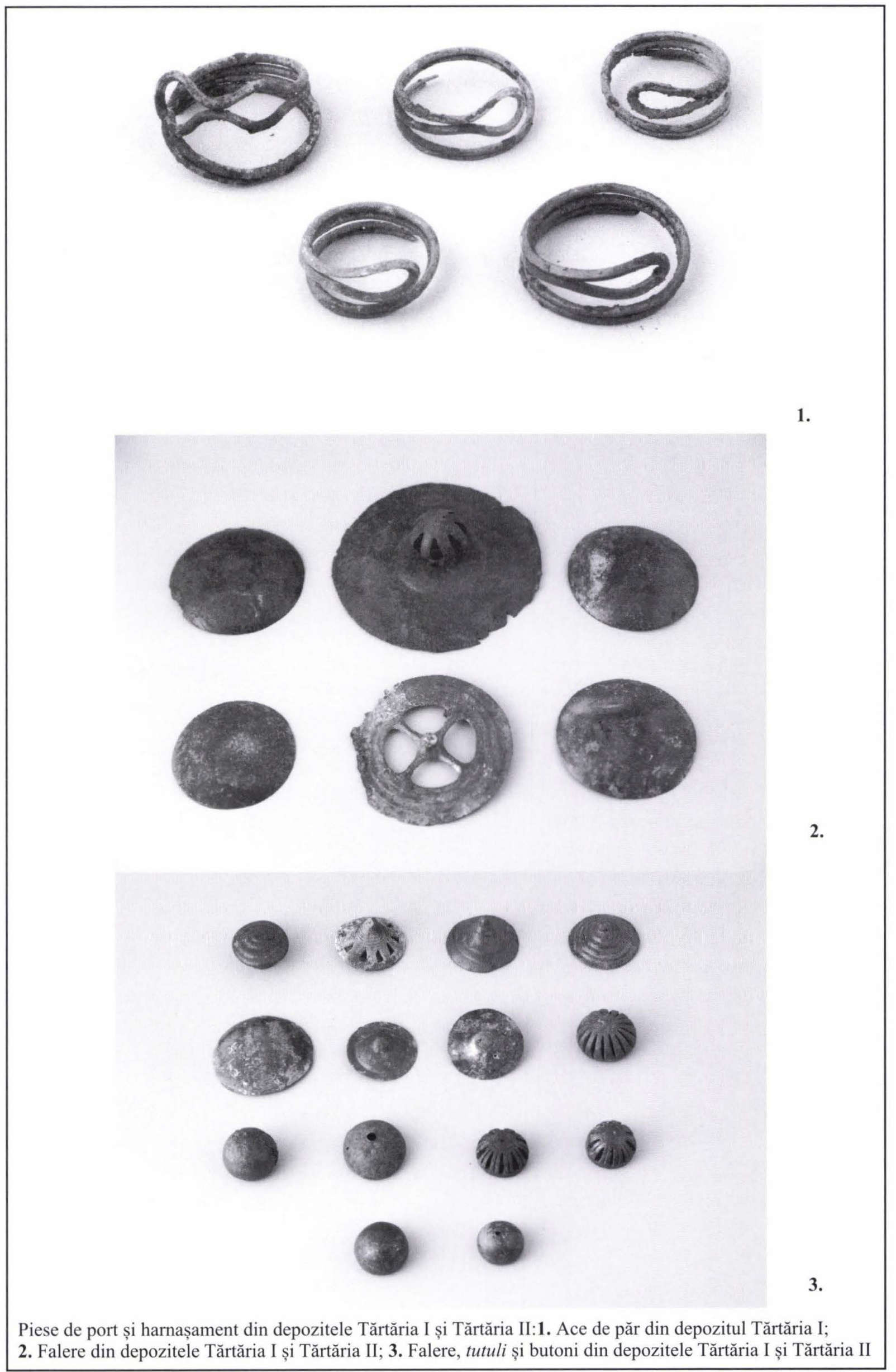




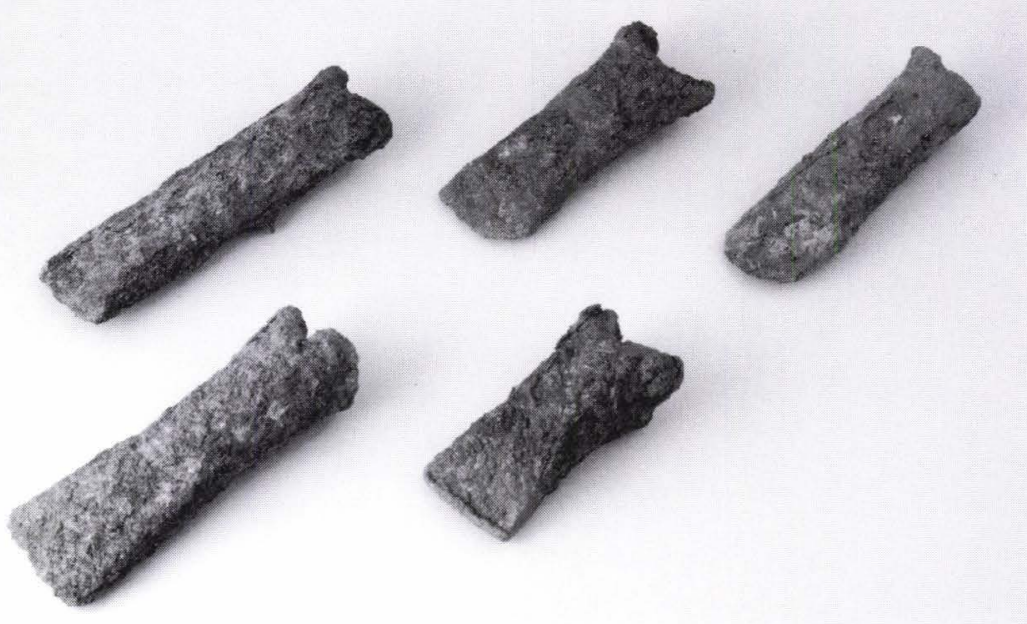

1.

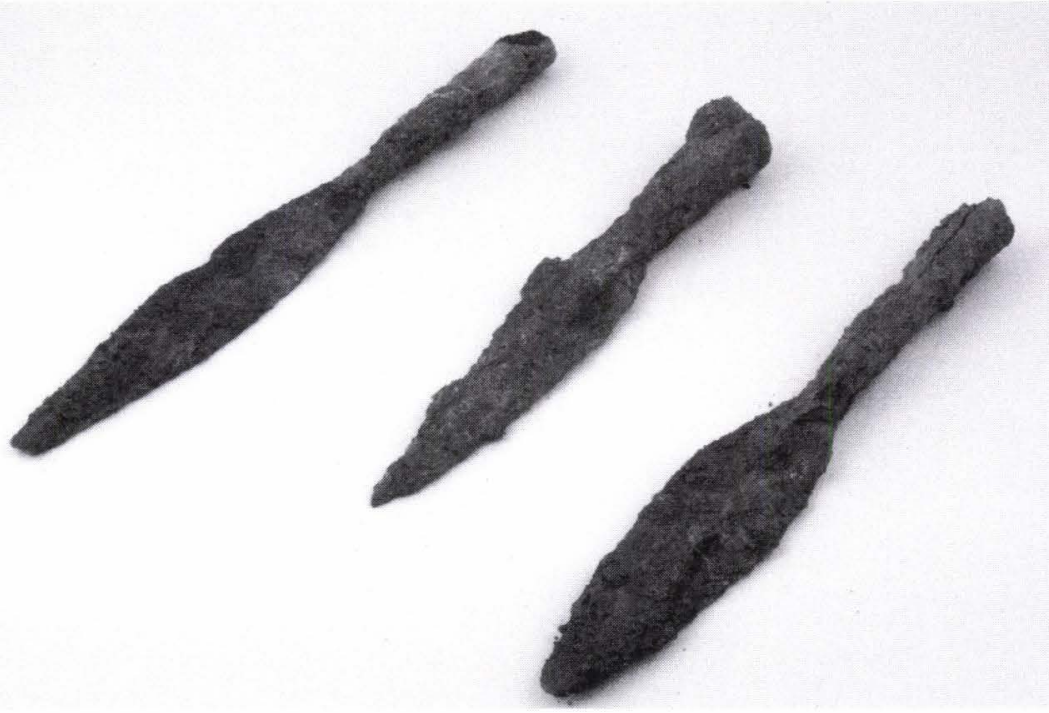

2.

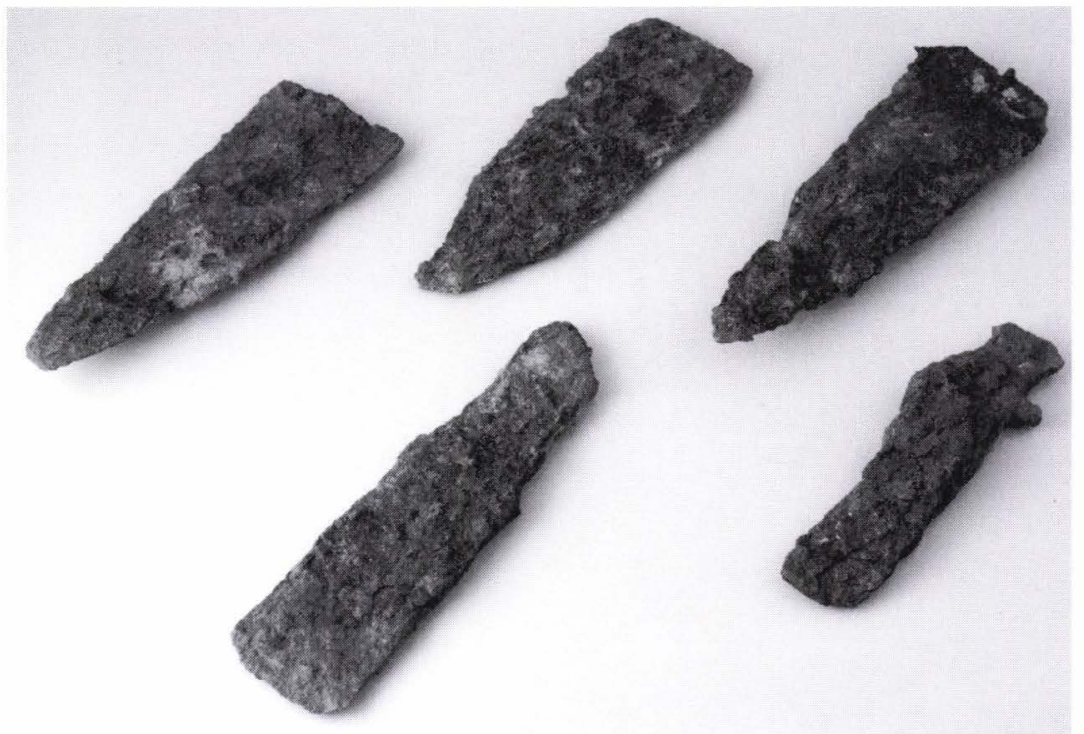

3.

Arme și unelte de fier din depozitele Tărtăria I și Tărtăria II:1. Celturi din depozitele Tărtăria I și Tărtăria II;

2. Lănci din depozitul Tărtăria II; 3. Spade scurte, daltă și topor cu aripioare din depozitele Tărtăria I și Tărtăria II 


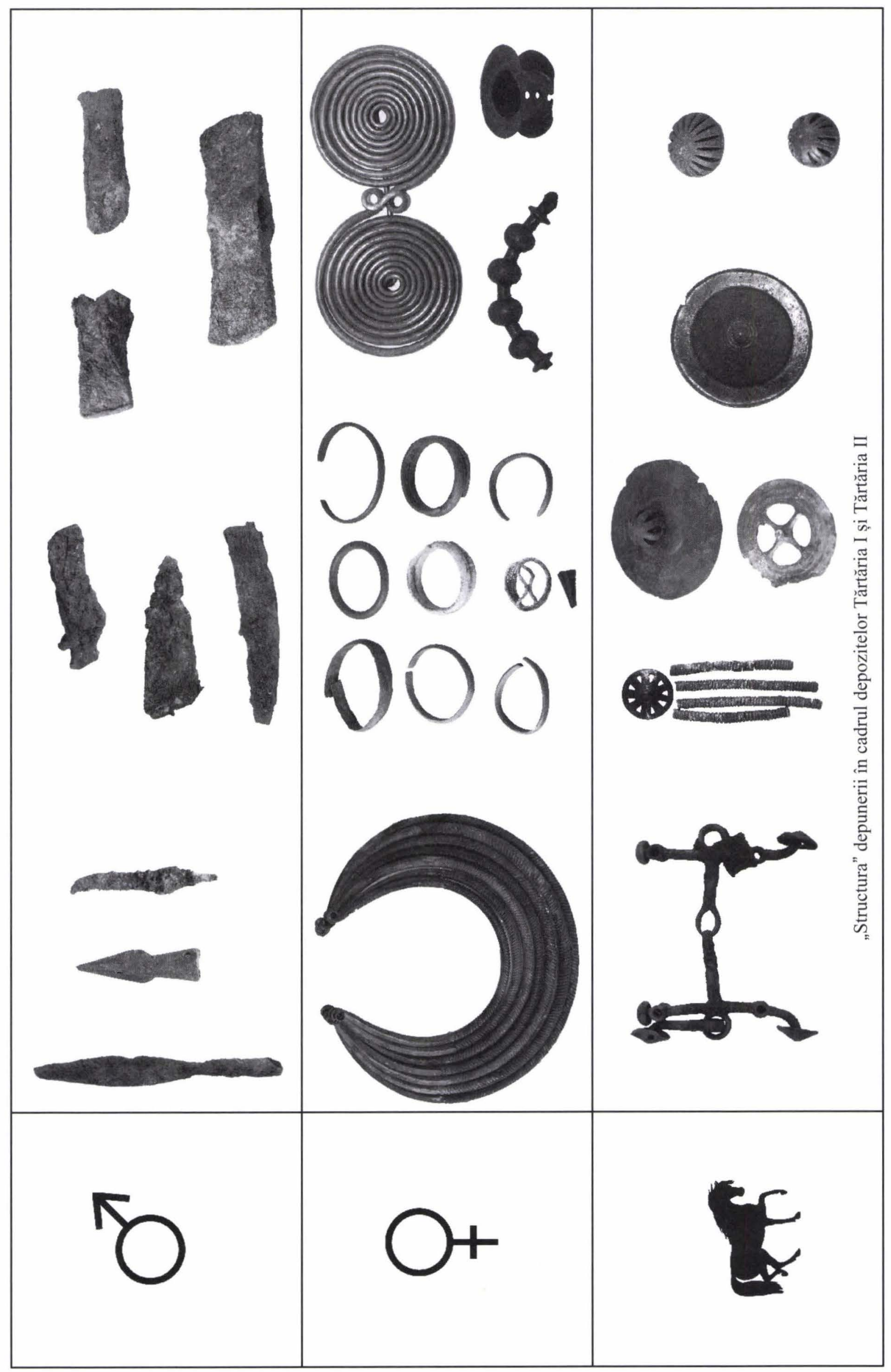

主 


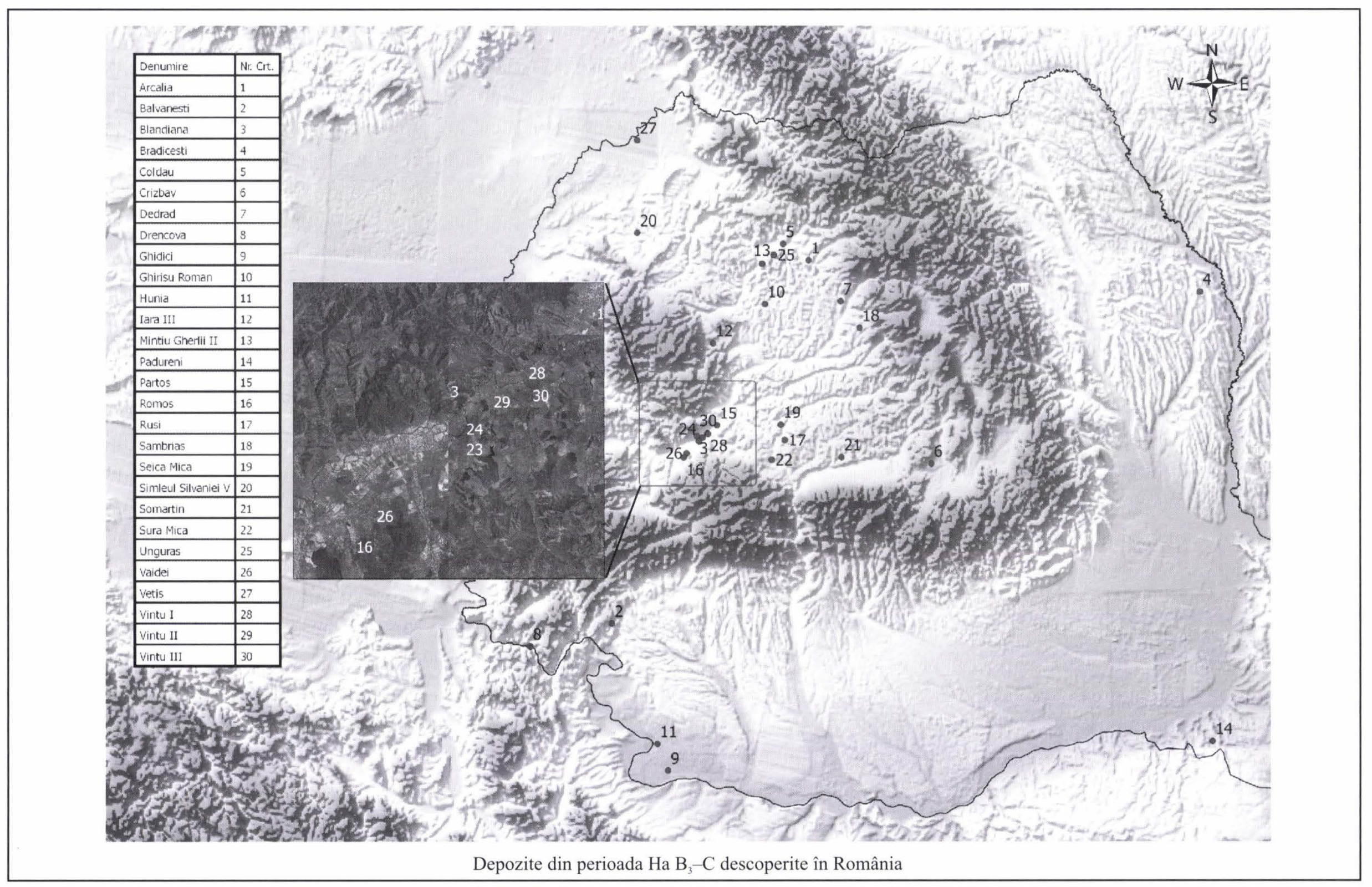

PI. LIV 


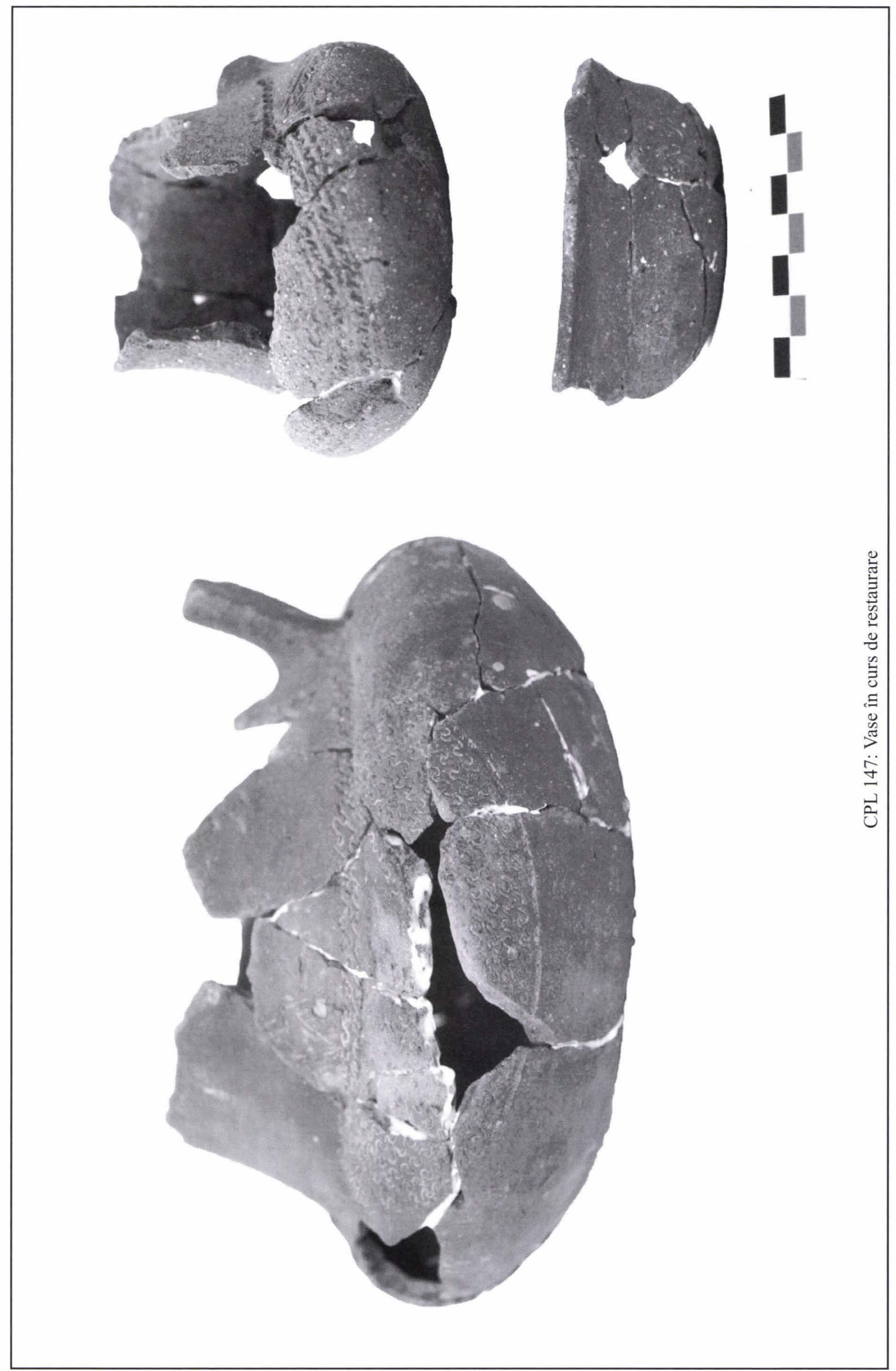

$\frac{3}{2}$ 


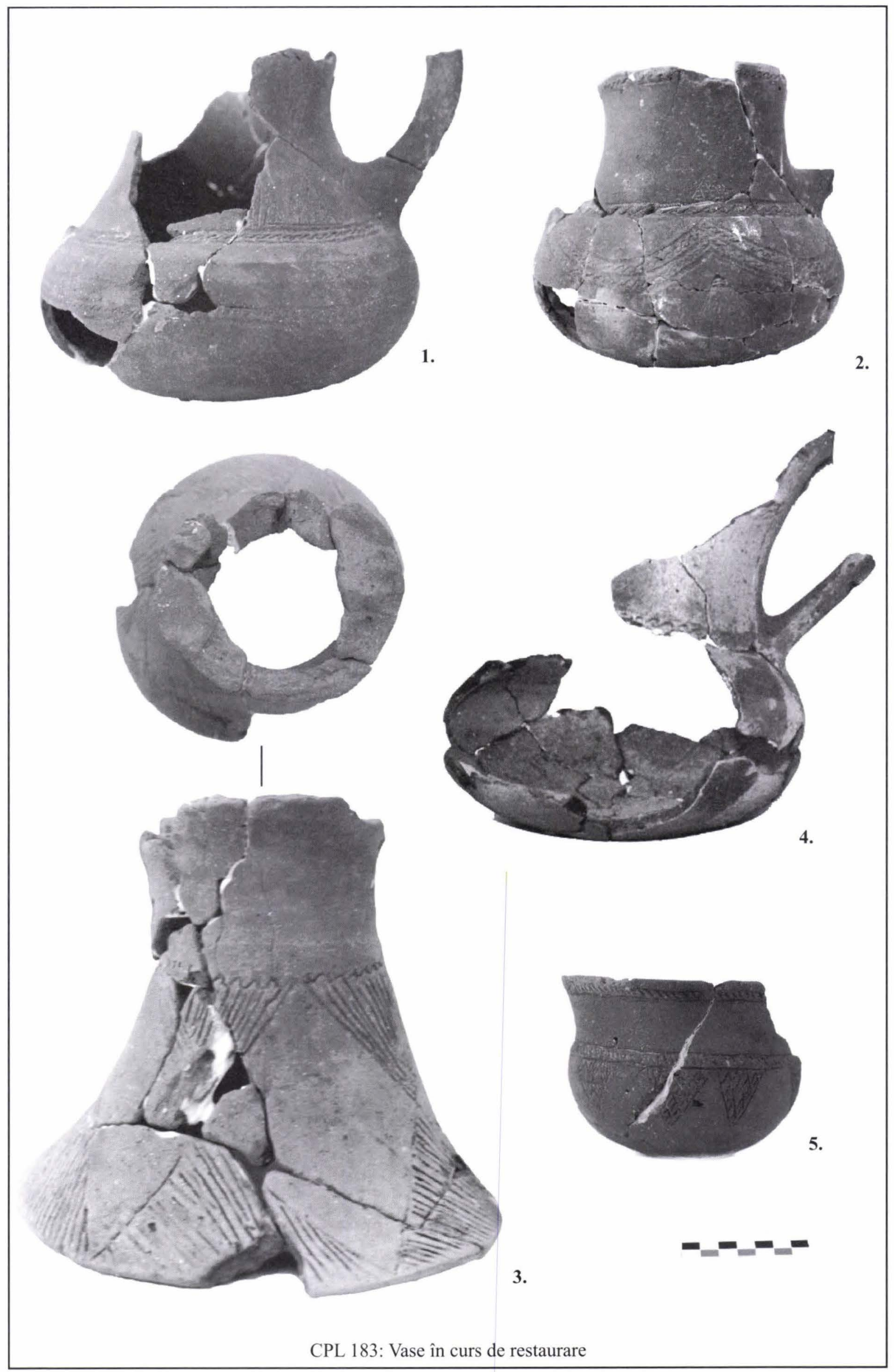

PI. LVI 


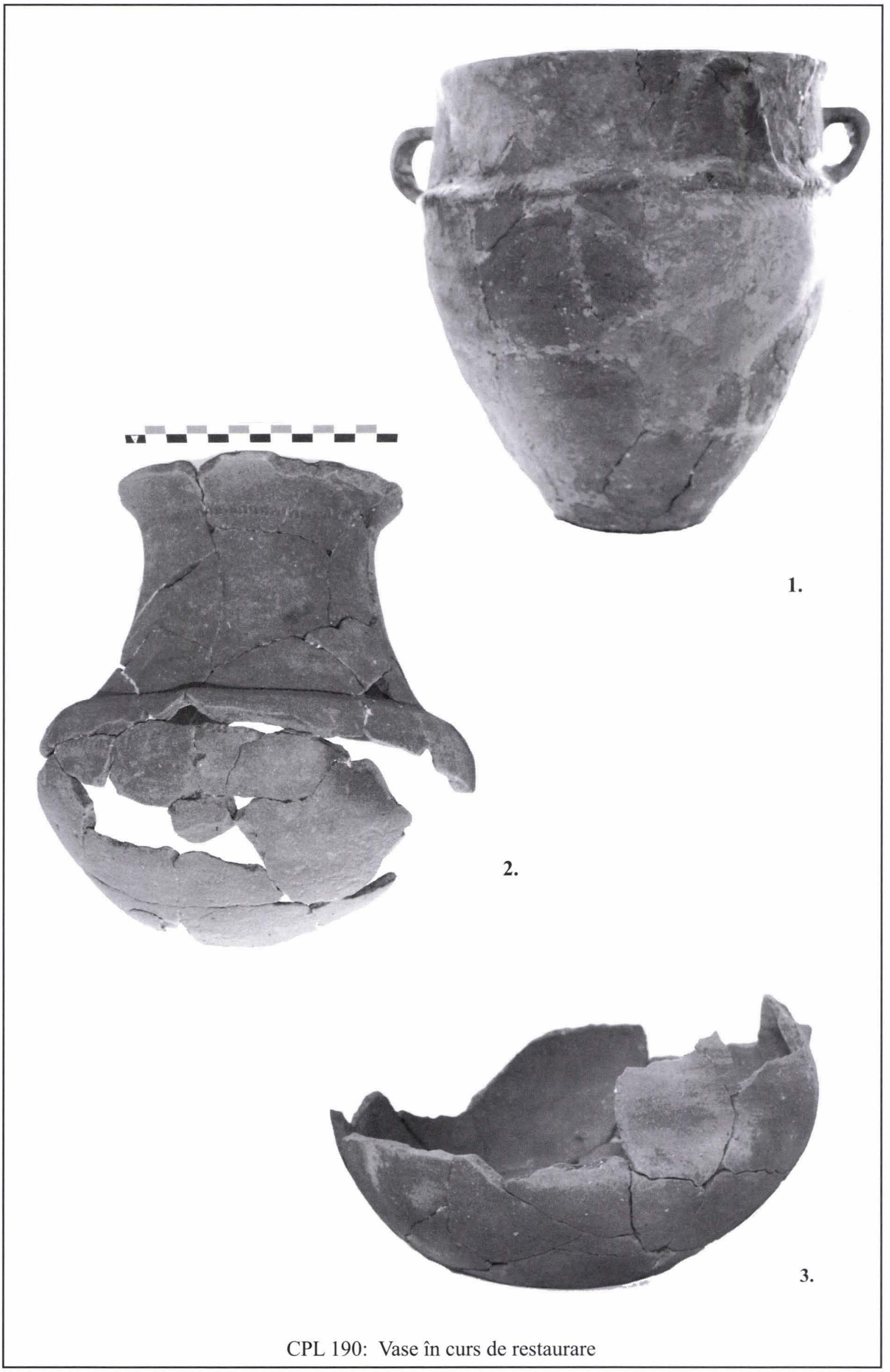

PI. LVII 


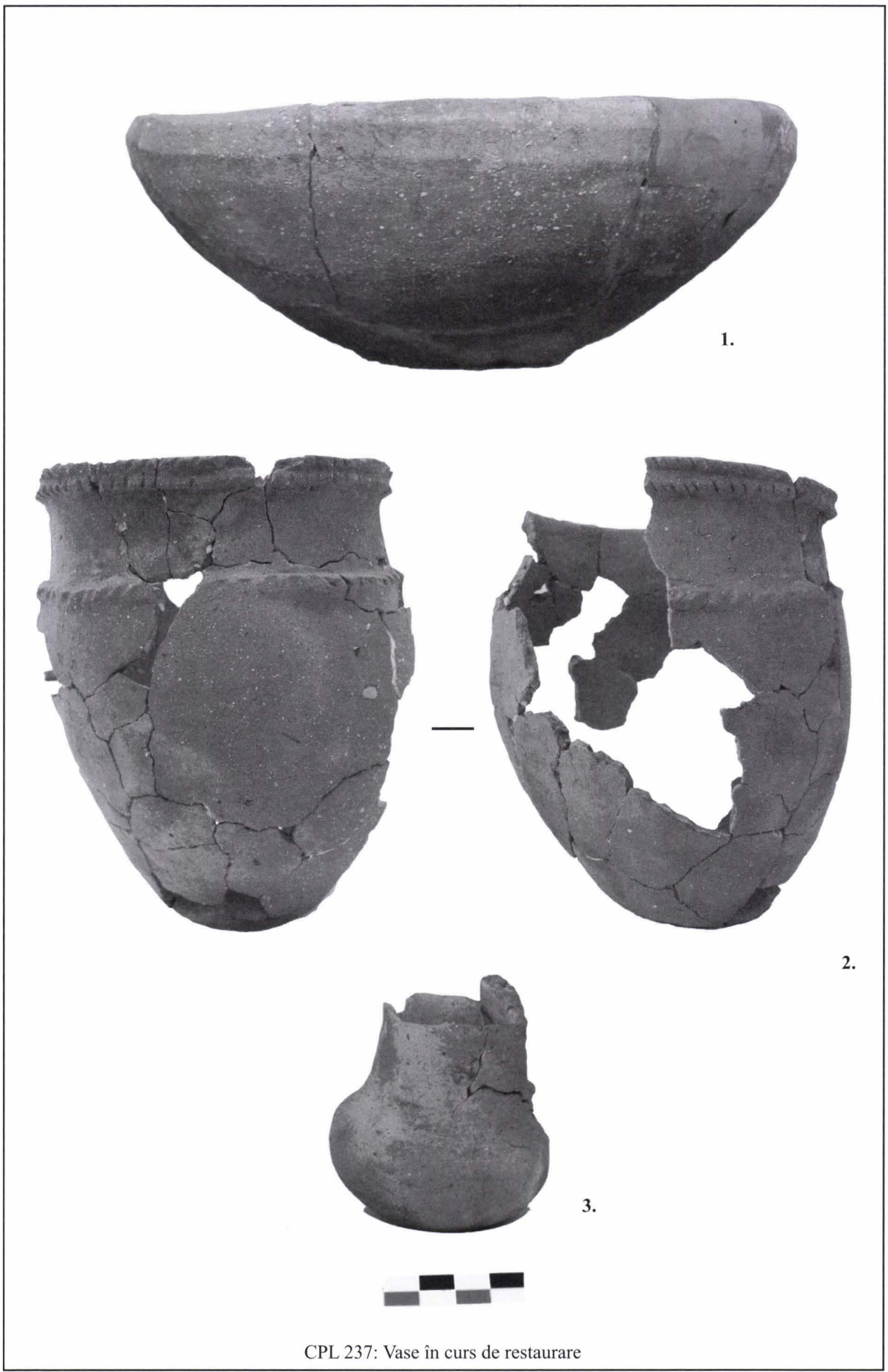

PI. LVIII 


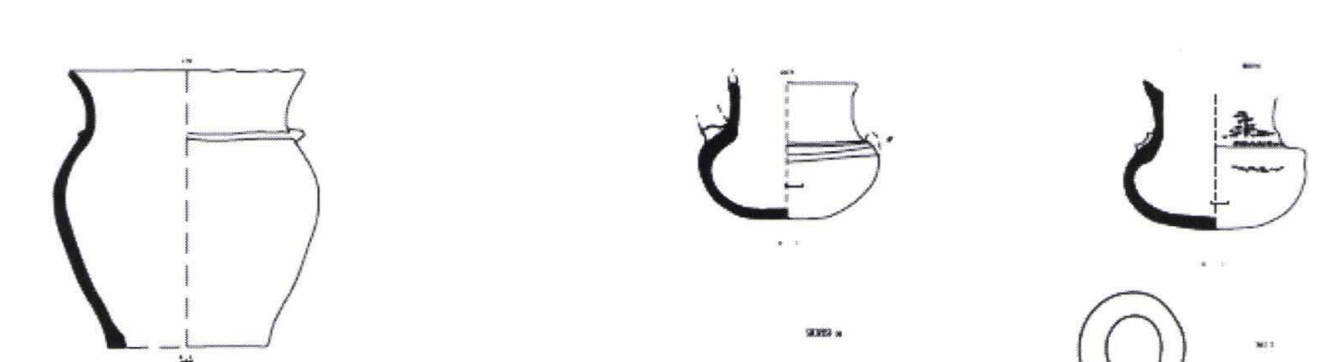

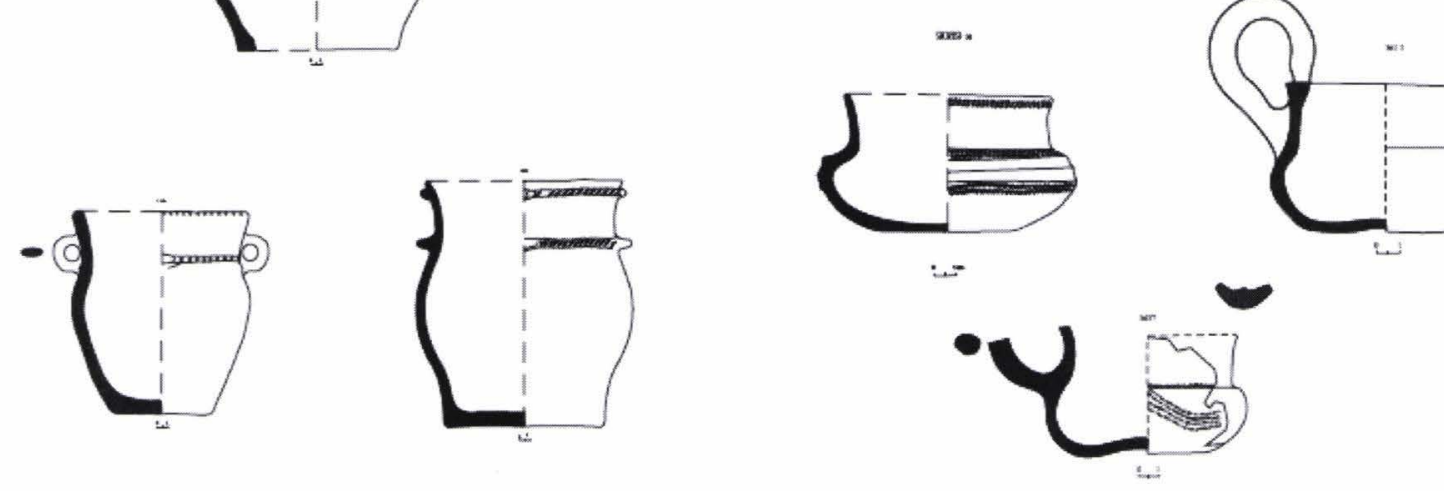

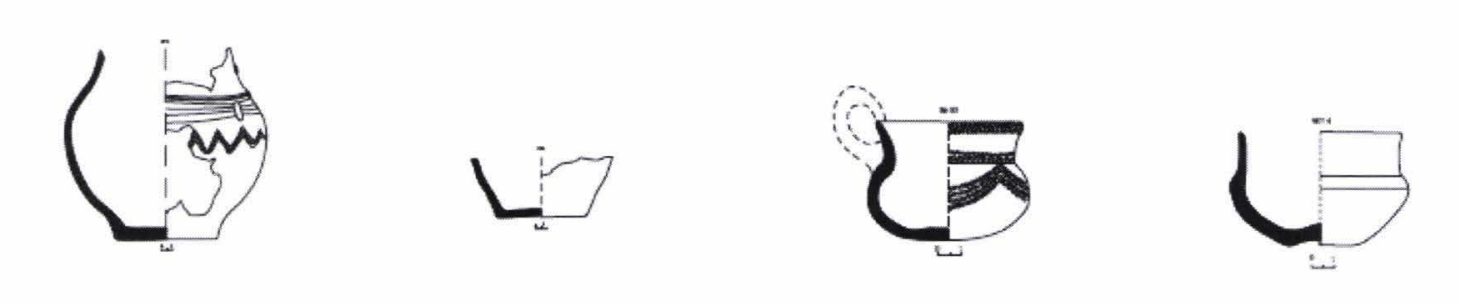

$$
\begin{aligned}
& \text { ) }
\end{aligned}
$$

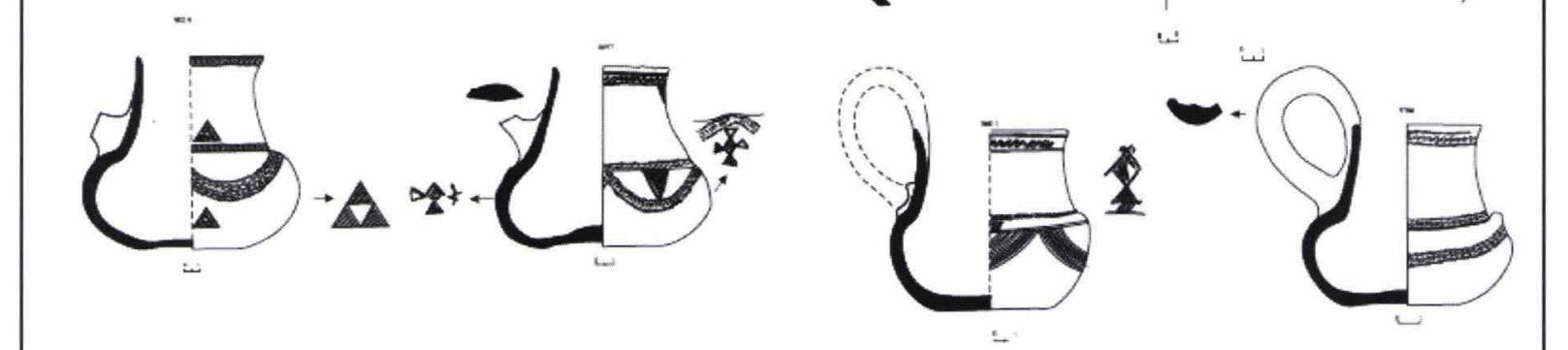

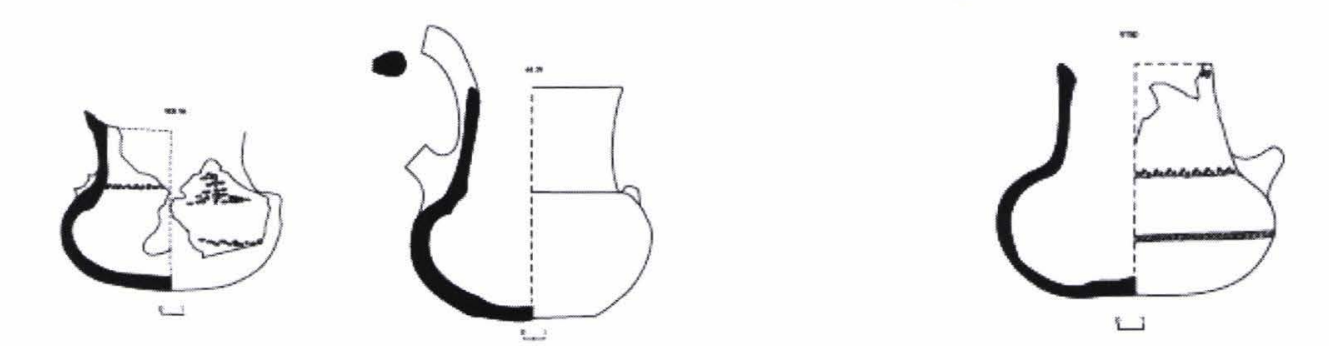




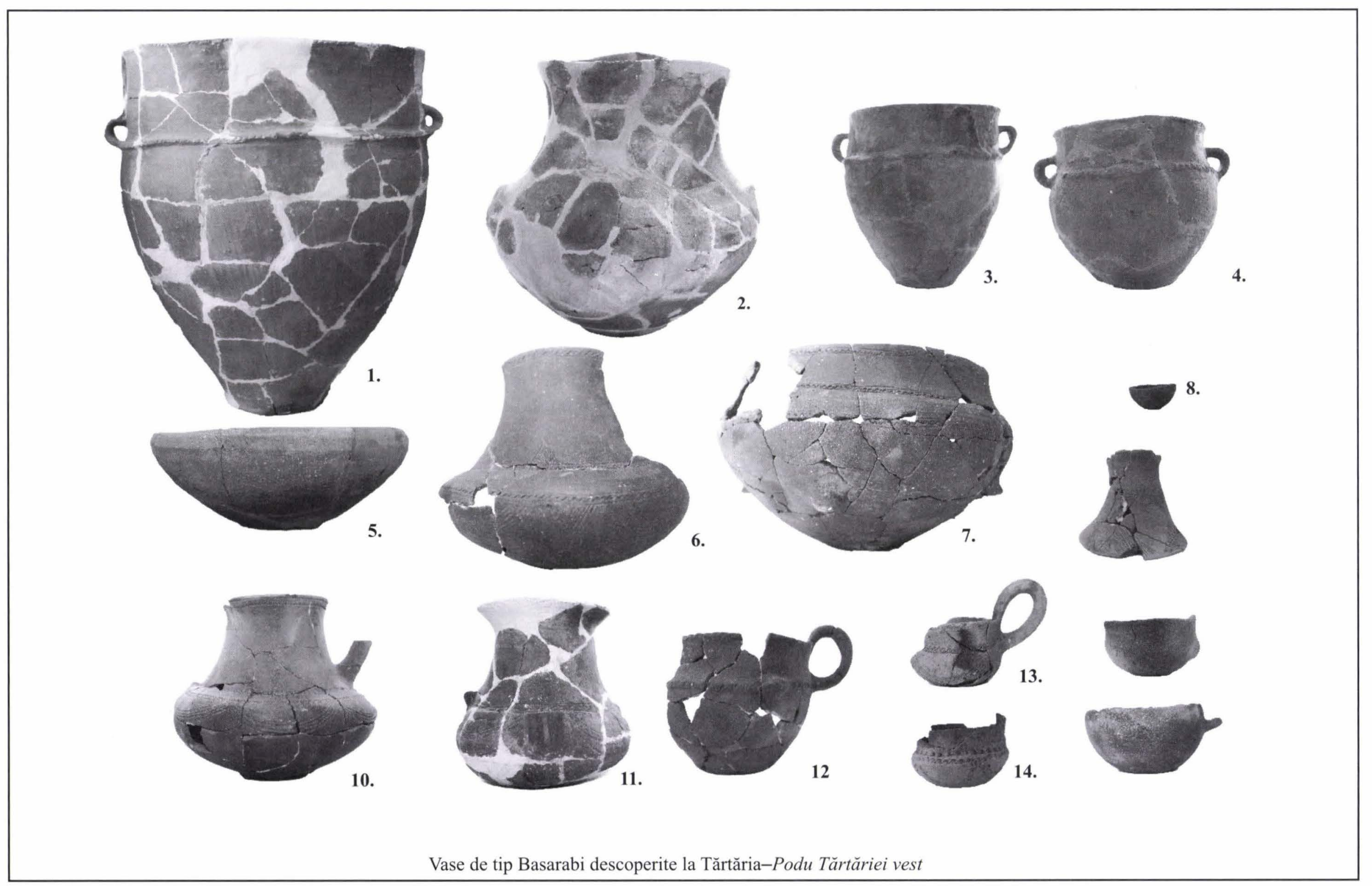

PI. LX 